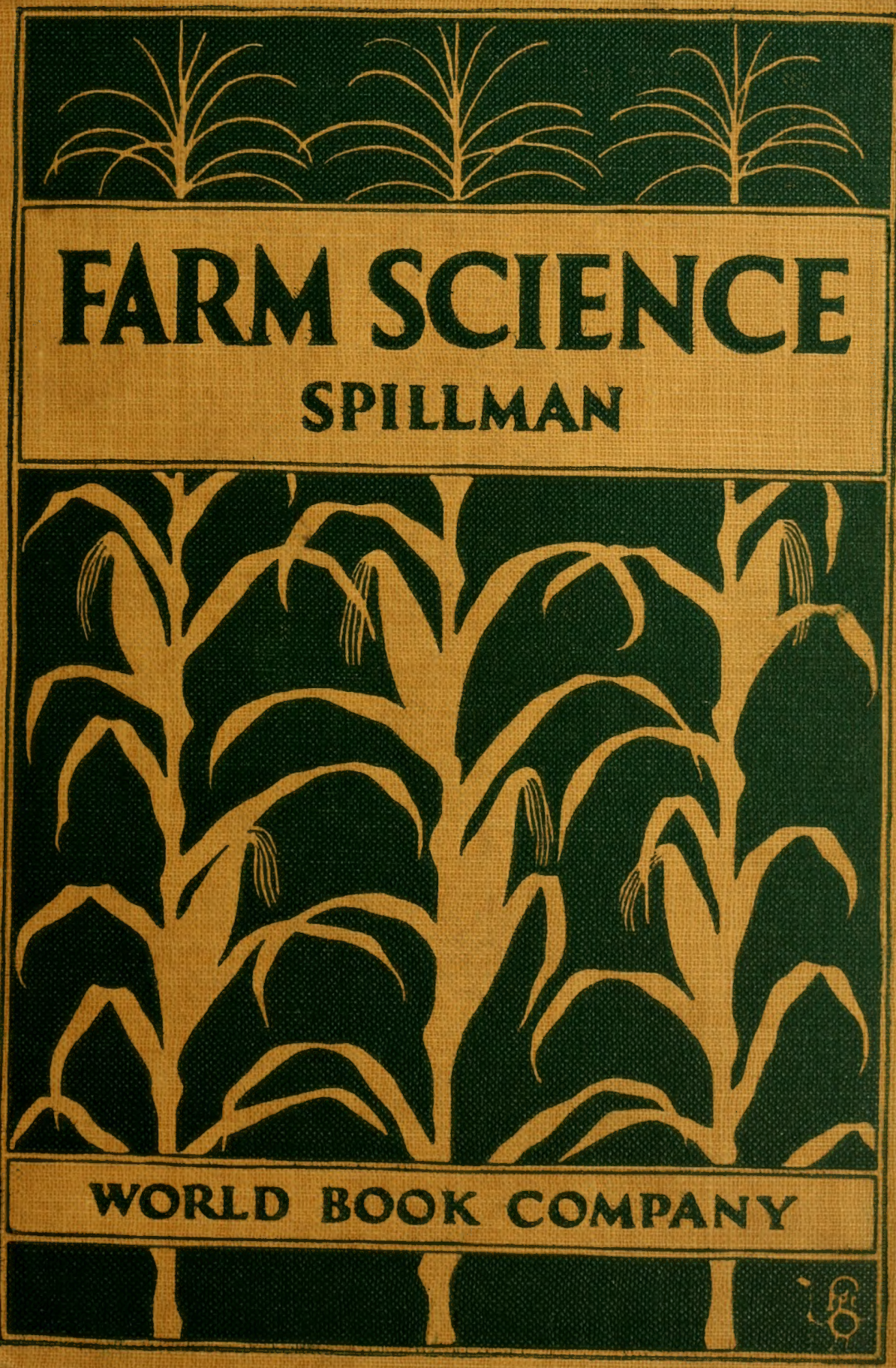




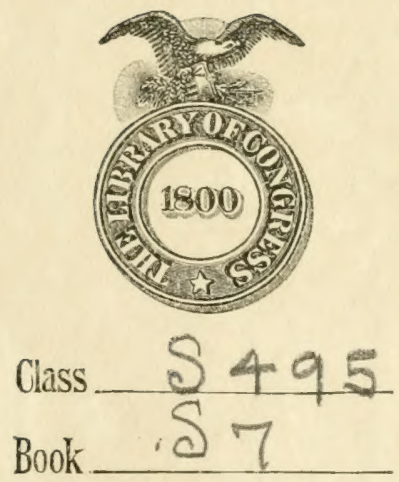

Copyright $\mathrm{N}^{\circ}$.

COPYRIGHT DEPOST. 





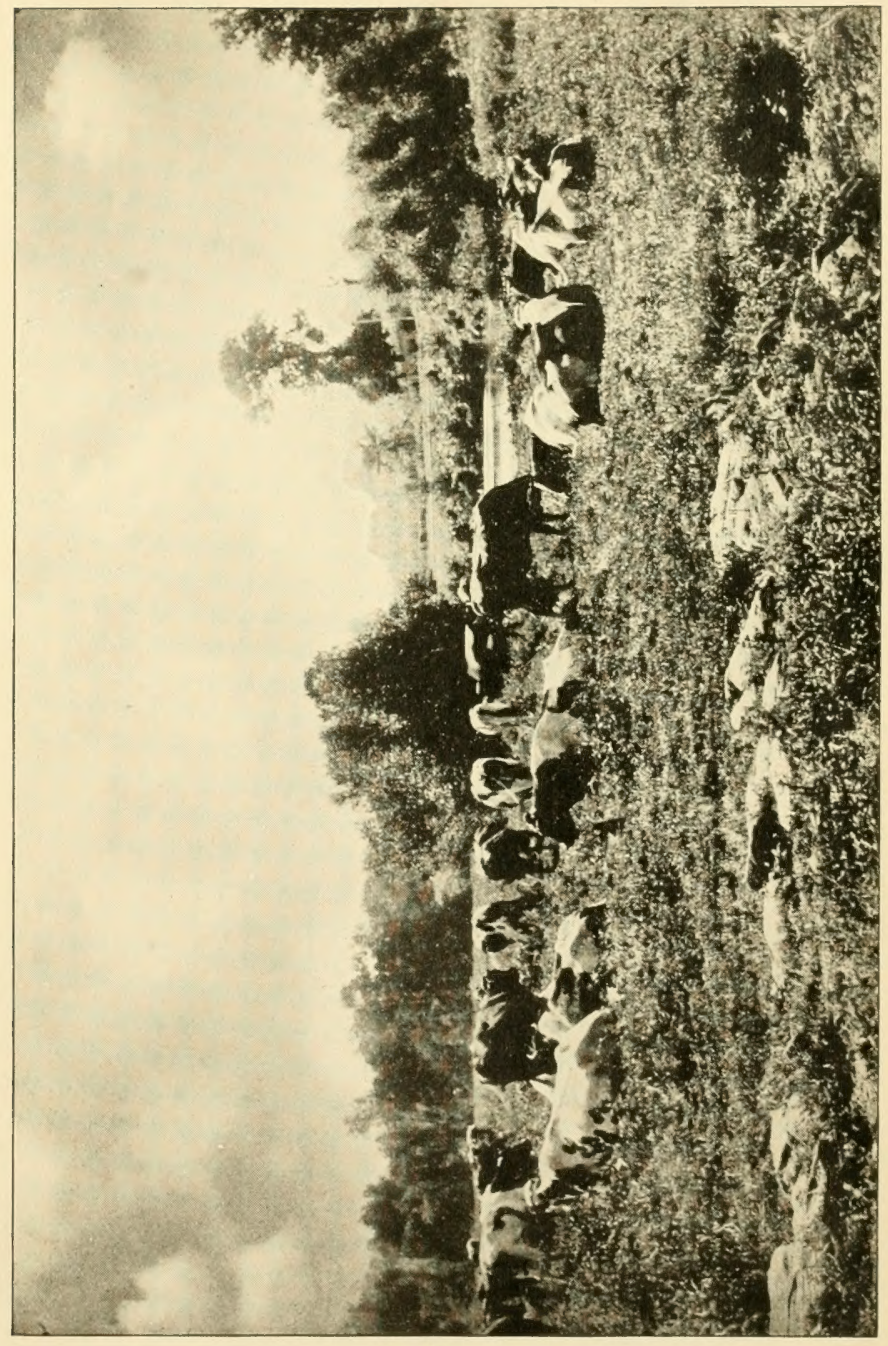


NEW-WORLD AGRICULTURE SERIES Edited by W. J. Spillman

\title{
FARM SCIENCE
}

A Foundation Textbook on AGRICULTURE

\section{By W. J. SPILLMAN, D.Sc.}

Chief of the Office of Farm Management

United States Department of Agriculture

Formerly Professor of Agriculture in the Washington State College

Professor of Science in Vincennes University, Indiana

Professor of Science in the Monmouth, Oregon, State Normal School Professor of Science in the Cape Girardeau, Missouri, State Normal School

\author{
ILLUSTR ATED \\ from photographs, and with \\ original drawings by \\ R. C. Steadman and \\ 7. M. Shull
}

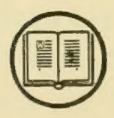

\author{
Yonkers-on-Hudson, New York \\ WORLD BOOK COMPANY \\ $\begin{array}{llll}\text { I } & 9 & \text { I } & 8\end{array}$
}


WORLD BOOK COMPANY

THE HOUSE OF APPLIED KNOWLEDGE

Established, 1905, by Caspar W. Hodgson

YONKERS-ON-HUdSON, NEW YORK

2126 Prairie Avenue, Chicago

This house aims to publish books that apply the world's knowledge to the world's needs. At a time when the rate of increase in crop area in this country is less than half the rate of increase in population, and when the public generally recognizes that food production has become the limiting factor in our further development as an industrial people, it is highly desirable that the field of agriculture should be more adequately covered by school texts than is now the case. This book is the beginning of a series of such texts, to be edited by W. J. Spillman. Present knowledge of agriculture has been derived from thousands of years of farm experience, supplemented in recent years by patient research on the part of agricultural scientists. The books of the New-World Agriculture Series will attempt to cover both these phases of agricultural knowledge

NWAS : SFS $-\mathbf{I}$

Copyright, 1918, by World Book Company Copyright in Great Britain

All rights reserved 


\section{PREFACE}

THE aim of this book is to explain to the farm boy the facts about farming that have puzzled him. There are many mysteries that are not mysteries to the average boy, for the simple reason that he has never recognized their existence. No attempt is made in these pages to introduce the student to new mysteries except such as are necessary in connection with a proper explanation of those he has actually met in his experience on the farm. The primary idea underlying the book is to enable the farm boy to understand the reasons for the things he has observed but does not understand.

Many of the schools in which it is hoped this book will be used have no special laboratory equipment. For this reason the experiments outlined at the end of the various chapters require no apparatus and, for the most part, no materials not readily obtainable on the farm. It is believed such experiments will convey to the student the lessons intended, more certainly than those that must be conducted with apparatus of a pattern unfamiliar to him. They do not require the student to think in a new and strange language.

No attempt has been made to make the book "practical" in the sense of teaching those things the farmer usually learns by experience. The aim has been rather to enable the student to understand why things are as he knows them to be. It therefore deals with fundamental principles, which are the same everywhere, and which are valuable guides in all the work of the farm. It is thus adapted to one locality about as well as to another. A book intended to give practical directions for doing things on the farm might be valuable in a particular locality if written with special reference to that locality, but would be of little value for classroom use elsewhere. The author believes that when agriculture is put in proper pedagogical form, the textbook will deal with prin- 
ciples rather than with the details of practice, and this ideal has been adhered to in preparing the text. The teaching of farm practice requires a manual, or a series of manuals, to be used as guides in actual farm work.

The attempt has been made to put the subject matter in a form suitable for classroom use. In this matter the author has followed closely the structure of those textbooks which in his seventeen years' experience as a teacher he has found most satisfactory for this purpose. The degree of success attained in this respect can be determined only by experience. The author would welcome any criticisms or suggestions that would enable him to make the book more useful to the farm boys of America, for whom it has been written.

The illustrations used in the text have been obtained to a large extent from the files of government bureaus. Acknowledgment is here made of the author's indebtedness to the many individuals who have so generously permitted the use of material of this character, or who have given helpful suggestions as to choice of illustrations; also to Mr. M. B. Waite and Professor C. V. Piper, for suggestions as to treatment of fungi, to Professor C. F. Marbut, for suggestions concerning the chapters dealing with soils, and to my colleague, Professor J. W. Ritchie, for many helpful suggestions. For the original drawings which have been made of a number of subjects, expressions of appreciation are due the artists, Messrs. J. M. Shull and R. C. Steadman, for their coöperation with the author in carrying his suggestions through to completion. 


\section{CONTENTS}

\section{PART ONE - THE SOIL}

CHAPTER

PAGE

I. What THE SOIL IS . . . . . . . I

2. Distribution of Soll Material . . . . 2 I

3. Soll Texture . . . . . . . . 33

4. Moisture in the Soll . . . . . . 49

5. Tillage . . . . . . . . 60

6. Terracing, Drainage, Irrigation, AND DRy Farming it

7. SOIL IMPROVEMENT . . . . . . . . 93

PART TWO - THE PLANT

8. Plant Organs and Their Uses . . . . I 2 I

9. How Plants Live . . . . . . . I 29

io. Fertilizers . . . . . . . I55

i . Plant Propagation . . . . . . I62

I 2. WEEDS. . . . . . . . . I86

I3. Insect Pests . . . . . . : I92

I4. FUNGI . . . . . . . 201

\section{PART THREE - THE ANIMAL}

I.5. Pleposes for IHich Livestock Are hept oN the FARM . . . . . . . $22 \mathrm{I}$ I6. BREEDS OF LIVESTOCK . . . . . 233 I7. Principles of Feeding . . . . . . 256

\section{PART FOUR - THE FARMI}

I8. The FarM Business . . . . . . 265 io. How to Seclre Best Results from Growixg Crops 2is 20. LIVESTOCK ENTERPRises . . . . . 303 21. The Fara Investaent And Income . . . 323 INDEX 



\section{PART ONE - THE SOIL}

\section{CHAPTER ONE}

\section{WHAT THE SOIL IS}

The four layers of the earth. The outermost portion of the earth is the atmosphere. We live at the bottom of an ocean of air. We are to learn that air is all-important to life, both plant and animal.

The second layer of the earth consists of water, but this layer covers only about three fourths of the earth's surface. Water plays as important a part in the maintenance of life as does air.

The third layer consists of the loose material we call earth, dirt, or soil. It covers the whole earth except in steep or exposed places where rain washes it away and leaves the underlying rocks bare. It extends under all the oceans. In reality only a few inches of the surface of the loose dirt layer, and that only on dry land, is properly called soil. The thickness of the loose dirt layer varies from almost nothing to many hundreds of feet.

The fourth layer consists of solid rock, which extends downward as far as we know anything about the structure of the earth.

The soil is the foundation of agriculture, and it is fitting that we should begin our study of this important and interesting subject by learning what we can about the soil.

\section{FACTS FROM OTHER SCIENCES}

Before we can understand some of the processes concerned in the making of soil material, we need to learn a 
few facts from other sciences. Such of these facts as are necessary are given below.

The magnet. Nearly every one knows that a magnet will pick up small pieces of iron. It is not so well known that the quantity of iron a magnet will thus pick up and hold is quite limited, and that when this quantity has been brought in contact with the magnet, the latter appears to lose all power of magnetic attraction for additional iron. We say its magnetism has been "saturated." A knowledge of this property of magnets will help us to understand the principles of chemistry.

The atom. All substances are composed of small particles called atoms. These are so small that they cannot be seen even with the best microscope ever made. How we know of the existence of atoms, and of their exceedingly small size, is a story much too long to tell here. It is told in the science of chemistry.

So far as we know, there are only about 90 different kinds of atoms in the entire universe. The spectroscope tells us that the distant stars have, for the most part, the same kinds of atoms in them as those that compose substances here on the earth. All the numerous substances known are composed of these 90 odd kinds of atoms united in various proportions. There is some uncertainty as to the exact number of kinds of atoms, for some of them occur only in rare substances, and chemists have not yet fully proved the existence of some of the kinds that are believed, but not certainly known, to exist.

Most kinds of atoms have strong attractions for each other, but the attraction between some kinds is stronger 
than that between others. Atoms are, in fact, small magnets, and like magnets, their attractions can be saturated. This means that an atom may be so united with other atoms that its attraction for additional atoms disappears. But with very few exceptions, an atom which has been torn loose from all combination with other atoms will attach itself to almost any kind of atom it can find.

Molecules. When two or more atoms join into a group in which the attracting power of each is satisfied, the group is called a molecule, a word meaning "little body:" Such a body can exist alone indefinitely unless the group of atoms constituting it is violently broken apart.

The atoms of quicksilver have a peculiarity possessed by few, if any, other kinds of atoms. They will unite readily enough with several other kinds to form molecules, but they do not unite with each other, so that when this substance is obtained in a pure form, its atoms remain apart as if their attractions were satisfied. We do not know why this is, but it is probably due to some peculiarity in the structure of these atoms which enables them actually to satisfy their own attractions. If we define the molecule of a substance as the smallest particle of that substance that can exist alone indefinitely, then we may say that the molecules of quicksilver consist of a single atom. The molecules of other substances consist of two or more atoms so united that the attracting power of each atom is satisfied.

Elementary and compound substances. When the atoms in a molecule are all of the same kind, the sub- 
stance composed of such molecules is said to be an clementary substance - it consists of a single chemical element. Iron is an elementary substance. Copper and sulfur are others.

If the molecules of a substance are made up of two or more kinds of atoms, the substance is said to be compound. Such a substance is composed of two or more chemical elements. Common table salt is a compound substance. Its molecules are made up of two atoms, - one atom of the element sodium and one of the element chlorin. When sodium atoms are united with each other, they form the molecules of the metal sodium, an elementary substance. When chlorin atoms are united with each other, they form the elementary substance chlorin, which is a yellowish, very offensivesmelling gas. But when an atom of sodium unites with one of chlorin, they form a molecule of the compound which we call salt.

The molecules of some compound substances contain many atoms of several different kinds.

There can be, of course, only as many different kinds of elementary substances as there are kinds of atoms, while the number of compound substances is practically unlimited.

Chemical symbols. Chemists have invented a simple and convenient set of symbols for the various elementary substances. The symbol for an element is usually the first letter of its name. Thus $\mathrm{C}$ is the symbol for carbon, $\mathrm{O}$ for oxygen, $\mathrm{H}$ for hydrogen, $\mathrm{I}$ for iodin, etc. In some cases the names of several elements begin with the same ietter. In such cases the symbol may consist 
of two letters of the name, usually the first two, or of one or more letters of the Latin name. Examples: calcium, $\mathrm{Ca}$; chlorin, $\mathrm{Cl}$; iron, $\mathrm{Fe}$ (Latin, ferrum); sodium, $\mathrm{Na}$ (Latin, natrium). Some of the elements of which we shall see a great deal in this book are, with their symbols, nitrogen, $\mathrm{N}$; phosphorus, $\mathrm{P}$; and potassium, K (Latin, kalium).

Meaning of chemical symbols. Chemical symbols are used in two ways. First, they are often used merely. as abbreviations for the names of the elements, to save time in writing and speaking. The second and more important use is to represent a single atom of an element. Thus " $\mathrm{CaO}$ " represents a molecule of quicklime, composed, as its symbol indicates, of one atom of calcium and one of oxygen. Some kinds of molecules have two or more atoms of the same kind in them. Thus a molecule of oxygen consists of two atoms of oxygen, and its molecular symbol is $\mathrm{O}_{2}$. A molecule of water consists of two atoms of hydrogen and one of oxygen; its symbol is $\mathrm{H}_{2} \mathrm{O}$. The molecular symbol of limestone is $\mathrm{CaCO}_{3}$. which means that a limestone molecule consists of one atom of calcium, one of carbon, and three of oxygen. The molecular symbol of carbonic acid gas is $\mathrm{CO}_{2}$.

Chemical reactions. When limestone is heated, the change that occurs is represented as follows:

$$
\begin{aligned}
& \mathrm{CaCO}_{3} \rightarrow \mathrm{CaO}+\mathrm{CO}_{2} \\
& \text { limestone } \rightarrow \text { quicklime }+ \text { carbonic acid gas }
\end{aligned}
$$

This means that the molecule of limestone breaks up and the atoms rearrange themselves into one molecule of quicklime and one of carbonic acid gas. This 
formation of new molecules from old ones is called a chemical reaction. In such reactions the atoms rearrange themselves so that in each case every atom has its power of attraction satisfied.

When we add water to quicklime, as is done in slaking it, the following reaction occurs :

$$
\begin{array}{r}
\mathrm{CaO}+\mathrm{H}_{2} \mathrm{O} \rightarrow \mathrm{CaO}_{2} \mathrm{H}_{2} \\
\text { quicklime }+ \text { water } \rightarrow \text { slaked lime }
\end{array}
$$

a new arrangement of atoms by which a molecule of quicklime and a molecule of water unite to form a molecule of slaked lime. The molecular symbol $\mathrm{CaO}_{2} \mathrm{H}_{2}$ is usually written $\mathrm{Ca}(\mathrm{OH})_{2}$, for reasons which we need not explain here.

\section{Experiments}

I. Get at a lumberyard, or elsewhere, a chunk of quicklime. Place it on a board or in a shallow box. Pour water on it, a little at a time, till it has completely crumbled. The water unites molecule by molecule with the quicklime, forming slaked lime. Since the newly formed molecules are larger than the molecules of quicklime, they cannot occupy the same space; hence the crumbling.

The quicklime may become very hot in this experiment. Take care not to set anything on fire with it. What would happen if a hard rain should fall on a wagon box full of quicklime?

2. Blow the breath through a straw into a glass of clean drinking water. Nothing happens. Now take a fresh glass of the same water and put some of the slaked lime in it - say, a tablespoonful. Stir up the slaked lime in the water and then let it settle. Pour off the clear liquid into another glass, being careful not to get any of the sediment. Now blow the breath into this clear liquid (limewater). The cloudiness that follows is due to chemical reaction between 
the carbonic acid gas in the breath and the slaked lime dissolved in the water, as follows:

$$
\mathrm{CaO}_{2} \mathrm{H}_{2}+\mathrm{CO}_{2} \rightarrow \mathrm{CaCO}_{3}+\mathrm{H}_{2} \mathrm{O}
$$

In this reaction the atoms of a molecule of slaked lime and a molecule of carbonic acid gas rearrange themselves so as to form a molecule of limestone and a molecule of water. While slaked lime is somewhat soluble in water, limestone is not, or at least very slightly so. Hence the newly formed molecules of limestone collect into small particles that appear as a fine white powder suspended in the water. A solid thus formed in a liquid in which it is not soluble is called a precipitate.

Continue to blow the breath into the cloudy water for several minutes, and suddenly the liquid will become perfectly clear again. The reason is as follows: the slaked lime in solution is finally all used up in forming limestone. As soon as this occurs, the additional carbonic acid gas in the breath becomes dissolved in the water, and the following reaction occurs :

$$
\mathrm{CaCO}_{3}+\mathrm{CO}_{2}+\mathrm{H}_{2} \mathrm{O} \rightarrow \mathrm{CaH}_{2}\left(\mathrm{CO}_{3}\right)_{2}
$$

This means that one molecule of limestone, one of carbonic acid gas, and one of water unite to form a molecule of acid calcium carbonate. This latter substance is readily soluble in water, and dissolves as fast as it is formed. When the limestone is all used up in the reaction, the liquid becomes clear again.

\section{HOW SOIL MATERIAL ORIGINATES}

Chemical action. We are now equipped with sufficient knowledge of chemistry to understand some of the most important processes in soil formation.

The original rocks of the earth's crust are at all times subjected more or less to the action of water, air, and 
numerous substances found in the soil. Chemical reactions are going on continually in the soil, and between the underlying solid rocks and substances in solution in the soil water that comes in contact with them. In this way the rocks are slowly broken down and converted into fine soil material, much as quicklime crumbles when slaked.

Most of the rocks of the earth's crust contain grains of quartz and other materials not easily affected by chemical agents, along with materials that are easily attacked. The more resistant grains remain to form the bulk of the soil after the more soluble ones have been dissolved by soil water and carried away. The soil is thus composed mainly of small rock particles of many sizes and kinds, though quartz grains make up the greater part of all ordinary soils.

In most parts of the country you can find stones that, when broken, show plainly in their outer portions that they have been changed by the action of water, air, or other substances, and are not so hard as in their inner portions. In time all such stones will fall to pieces and form soil.

It is mainly by processes like those described above that by far the greater part of the material composing the soil was derived from the solid rocks of the earth's crust. These processes are going on now just as they have always gone on. This is why the surface of the earth is nearly everywhere covered with dirt. It is only in exposed places where the dirt washes away as fast as it is formed that we find the bare rocks that extend down into the depths of the earth. 
How ice aids in soil formation. Those who live in cold climates know that when the water in a water pipe
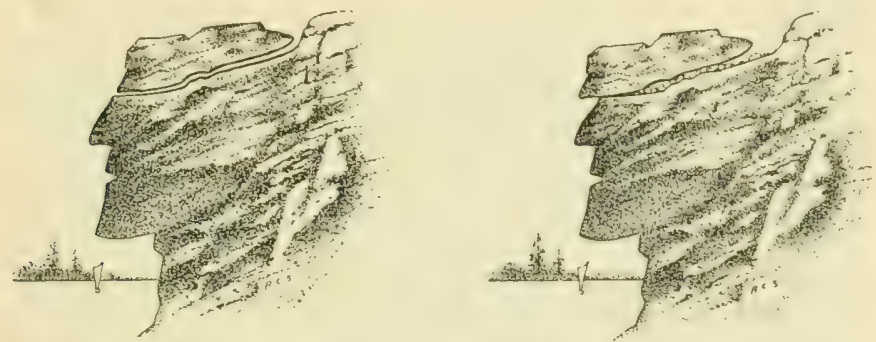

FIG. I. The Great Stone Face in the White Mountains of New Hampshire. Water creeps into the crevice behind and underneath the "cap," and freezes. The force of expansion is so great that the cap stone, weighing thousands of tons, is moved outward each winter. It is now being put back in position, and the crevice closed with cement.

freezes, it bursts the pipe. Because of this the pipes that bring water into the house are buried deep in the ground to keep them from freezing. The reason for the bursting is that water expands while freezing, and thus the ice occupies more space than did the water from which it was formed. This is because the molecules of ice are arranged in needlelike crystals, with more or less open space between the crystals, while in water the molecules have no particular arrangement, but move freely about among each other.

Figure I shows the enormous expansive force cxerted by freezing water. Every time the water freezes in the crevice behind and under the "cap " of the Great Stone Face, the huge cap, which weighs several thousand? tons, is moved outward a little. Engineers have recently been at work moving this cap back into place and filling the crevice with cement to keep the water out. 
Nearly all stones or rocks have crevices in them that get full of water. When the water freezes, the expansion breaks the stones, or at least chips off pieces of them. The repeated freezing and thawing of water in the crevices of rocks thus helps in the process of breaking up the rocks to form soil material.

How rolling stones form soil. In a freshet the stones lying in the bed of a stream are rolled considerable distances. Every time one of these stones strikes another, pieces are chipped from both. Every one has seen rounded stones, like those shown in Figure 2, that are found in stream beds or in places where they were left by flood waters. Each of these stones was sharpcornered when it was first split from a larger stone. What has become of the sharp corners? They have been worn off piece by piece, and these pieces now constitute part of the soil, especially in river and creek bottoms. However, there are in some regions rounded stones not formed in this manner.

A little figuring will show that a good deal of soil comes from this source. (See problem at end of this chapter.) If we grind off the corners of a cubical stone till it is perfectly round, we take off nearly half of it. From the number of water-worn stones found in most parts of the country, it is clear that no small part of the fine material we now call soil must have originated in this manner, though not nearly so much as was formed by the action of air, water, etc., in causing stones to fall to pieces.

The part played by glaciers. Both the north and the south pole of the earth are covered by thick layers of 


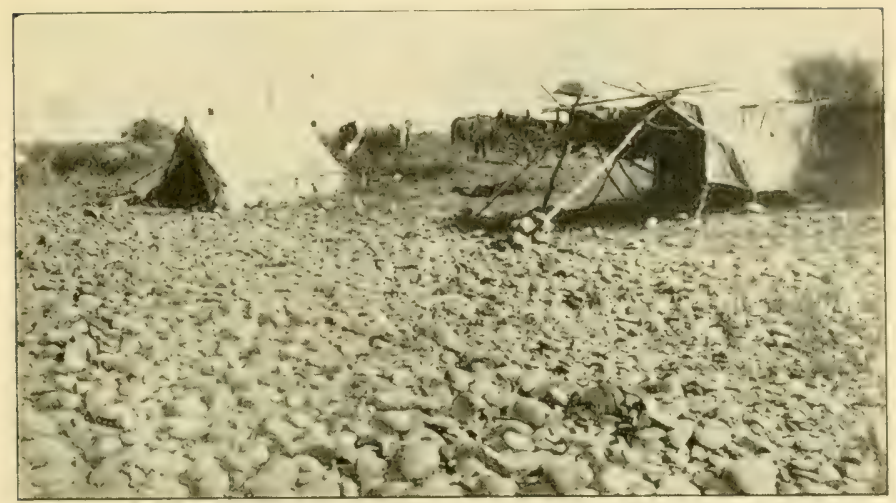

Office of Farm Management

FiG. 2. Water-worn stones in the bed of a stream. Each of these stones was sharp-cornered at one time. What has been worn off from them is now soil.

snow, compacted more or less into solid ice. These are called the "polar ice caps." Through the telescope we can see caps of this kind on the poles of the planet Mars.

Several times in the distant past the climate of the earth became much colder than it is now. During these long periods of low temperature, sometimes lasting for thousands of years, the polar ice caps spread out till they covered a large part of the earth. The north polar cap at one time came down to about where the Ohio River now is. In places the ice was several thousand feet thick, being thicker northward, of course. While ice is solid, it is not so solid as iron, for it will flow a little, just as very thick molasses does. ${ }^{1} \quad$ The ice cap slowly spread out (flowed) from the north, where it was thick-

${ }^{1}$ By subjecting a block of ice to very gradual pressure, it can be bent into any shape desired; but if subjected to sudden pressure, ice is very brittle. 


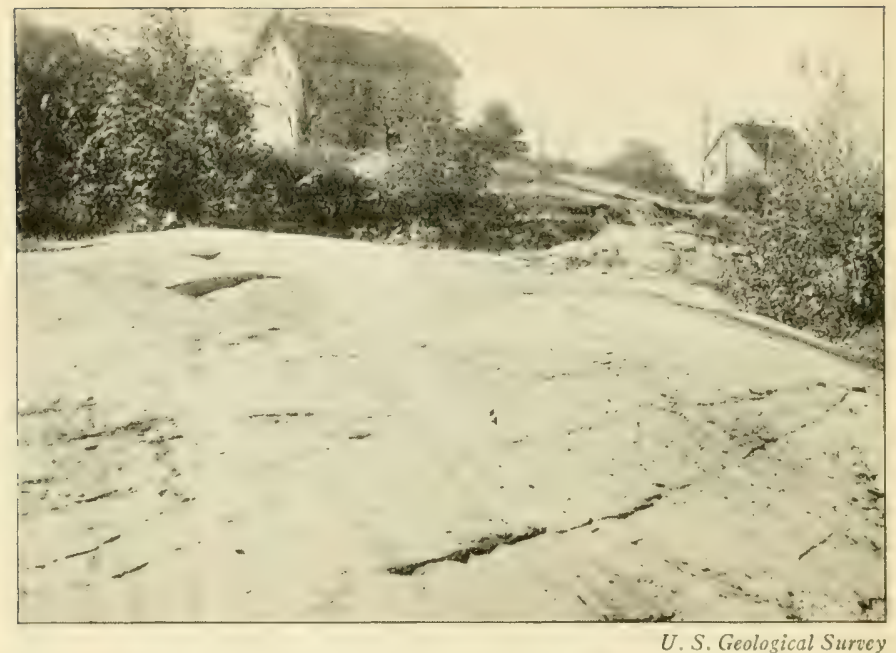

Fig. 3. Bed rock marked by rocks embedded in glaciers flowing ov $r$ it during the glacial puriod. Such rocks are found in many parts of the northurn statıs.

est, toward the south. Its enormous weight pressed into its lower surface much of the loose dirt and stones beneath it. These were dragged along the surface of the earth, grinding against everything they touched.

Many rocks were thus ground into fine powder, and much soil material was formed in this manner. Figure 3 shows a rock surface that was ground and scratched by the stones embedded in glacial ice moving slowly over it. In Figure 4 are shown stones that were embedded in the ice and were scratched by the rocks over which they were dragged. Such stones may be seen in any geological museum.

In its flow, a glacier would frequently meet with obstacles, causing it to buckle up here and there, turn 
this way and that, and thus frequently bring what was formerly the bottom ice to the top. In this way the stones and dirt became well distributed throughout the mass of the glacier, as is seen to be the case with the modern mountain glacier shown in Figure 5, page 14.

Finally, when the climate changed again, and it became warmer on the earth, the southern edge of the northern ice cap melted, and the millions of tons of rocks and dirt embedded in it were left on the earth's surface (Fig. 6, page I5). In some places the layer of earth thus deposited is a hundred feet or more in thickness. The surface soil of most of the region lying north of the Ohio and Missouri rivers is of this character. Much of it is merely dirt that the ice picked up and carried along with it as it flowed slowly southward. In some places there are four or five layers of this material, indicating that what is described above took place several times.

How so-called limestone soils are formed. In some large areas in this country the rocks seen in the bluffs

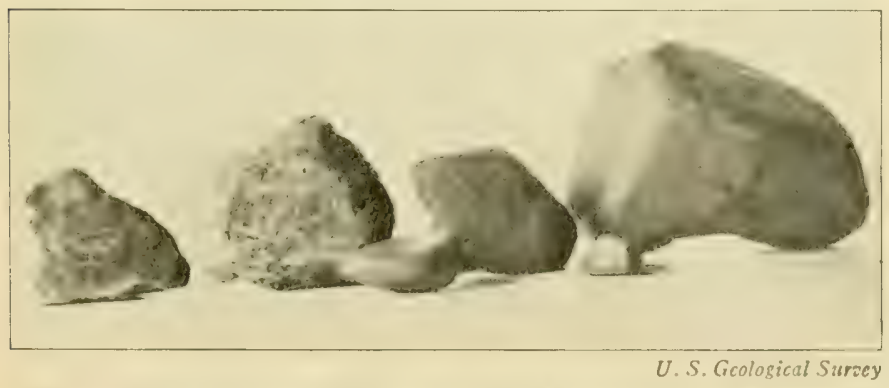

Fig. 4. Rocks once embedded in glaciers and scratched by being dragged over bed rock. 


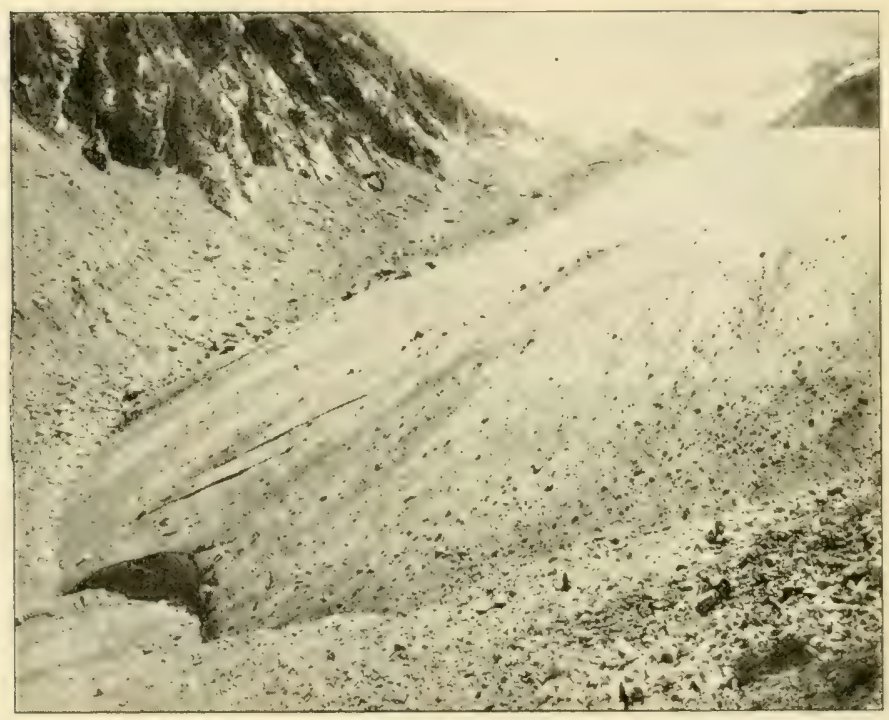

Harry Ficlding Reid

FIG. 5. End of a modern mountain glacier, showing rocks and dirt embedded in the ice.

along the streams are limestone. This is the case in part of the Ozark Region of southern Missouri and northern Arkansas, and in a large part of Kentucky and Tennessee. (See map facing page 32.) Now the atmosphere contains a small percentage of carbonic acid gas, and this gas is readily soluble in water. Rain therefore carries into the soil considerable quantities of this gas. More of it is formed in the soil as the result of the decay of plant and animal remains. We have already learned that water containing carbonic acid gas in solution will dissolve limestone. Because of the small amount of this gas in soil water, the action of water in dissolving 
limestone is very slow; but in areas where the rock underneath the soil is limestone, the upper surface of the stone is at all times being slowly dissolved away and carried back to the ocean, whence it originally came. But all limestone has embedded in it small particles of other kinds of rock that are not so easily dissolved and carried away. In some cases it contains large masses of flint, as well as many other kinds of mineral substances. When the limestone is dissolved away, these less soluble mineral particles are left as soil. Soils formed in this manner are usually called limestone soils, but where the rainfall is heavy, and especially if the resulting soil is rather porous, they may be very poor in lime, even where the limerock is only a few feet below the surface.

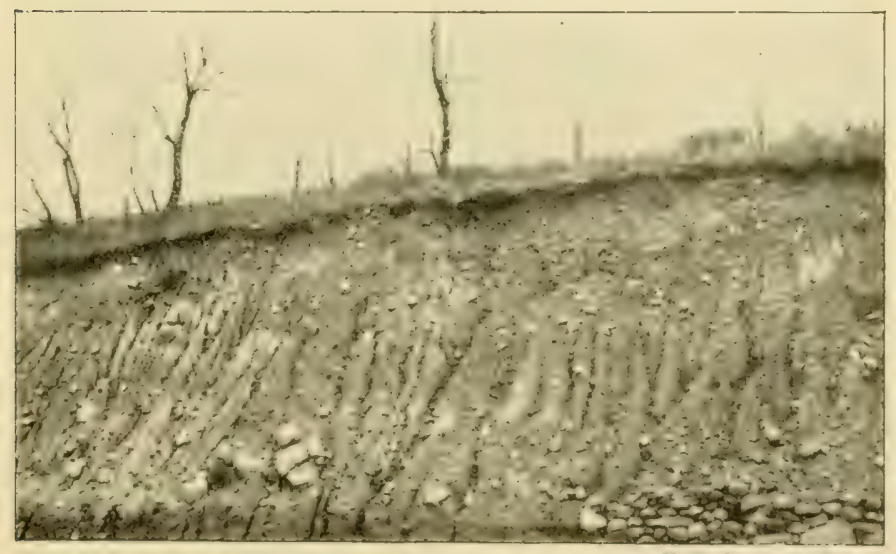

U.S. Giolevical Sirricy

FIG. 6. Soil material once embedded in a glacier, and deposited on the surface when the glacial ice melted. The gravelly character of this soil is characteristic of most glacial soils. 


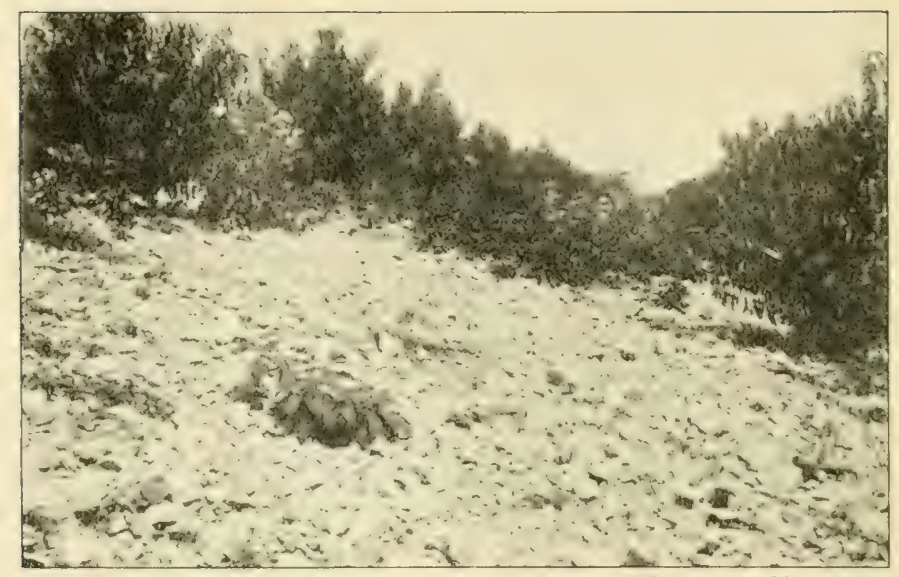

Office of Furm Manasement

Fic. 7. Flint rock once embedded in limestone, which was dissolved away. Smaller particles of soil washed to foot of hill, leaving rocky hillside.

In Figure 7 is shown a rocky soil that originated in the manner here described. In this case the original limestone contained a great deal of flint, often in large masses, though these masses had nearly always been broken into relatively small pieces by the forces that everywhere cause large rock masses to become cracked and broken. Figure 7 shows a hillside from which the rain has washed all the finer soil particles, leaving only the larger rocks to form the surface. Part of the fine dirt that was originally formed here is now lying in the valley at the foot of the hill.

The soils of the famous Bluegrass Region of Kentucky and of the Central Basin of Tennessee are derived from limestone that had much less flint in it, and they are not rocky like the soil shown in Figure 7 . There is also a large area of soil in western Texas that was formed 
from limestone in the manner here outlined. Smaller areas occur elsewhere. Look up these areas on the map facing page 32 .

The part played by plants and animals in forming soils. In the preceding paragraphs we have seen how the little rock particles that form by far the greater part of the soil came to be little particles instead of large stones. A good soil, however, contains something besides little pieces of stone. Plant roots rot in the soil. Leaves and stems fall to the surface, become mixed with dirt, and soon fall to pieces by decay. Uncounted millions of worms and bugs, mice, gophers, etc., die in the soil or on its surface. All these decaying remains of plants and animals are part of what we call the soil. Although they form only a small part of the substance of the soil, they are highly important to its fertility, as we shall see presently.

Chemical changes going on in the soil. You have noticed what happens to a piece of old iron that lies in contact with the damp soil for a few years. In the presence of moisture and air it is attacked by the oxygen of the air, with which it unites chemically to form iron rust. In time it is completely converted into ironoxygen compounds, and crumbles away much as lime does in slaking. The soil contains a great many substances, some of mineral origin, others derived from the decaying remains of plants and animals, that act on each other and on the rocks of the soil in much the same manner that air and moisture act on iron, though usually much more slowly. Such changes are always going on in the soil. The surface of almost erery rock particle 
in the soil is more or less stained and discolored by gummy substances that form in the soil as the result of these chemical activities. The soil is thus an exceedingly complex thing, and hardly any two samples of it are exactly alike. This makes it difficult to lay down any hard and fast rules for improving the soil. What is good for one soil is not always good for another. We shall find, however, that much can be learned about how to make the soil yield abundant crops.

WHAT A CUBIC INCH OF SOIL WOULD LOOK LIKE IF MAGNIFIED INTO A CUBIC MILE

Let us imagine, if we can, what a cubic inch of soil would look like if we could enlarge it to a cubic mile, or if we could reduce ourselves to small creatures that could crawl in and out between the particles that constitute the soil. Some of the little rock particles that form most of the bulk of the soil would then appear to us to be stones several feet through. Others would be no larger than a pea, while there would be still others of every size between these extremes. Most of the particles would look like the common flint stones seen in stream beds and in many regions beside the road, for they are indeed only small pieces of flint. But there would be an occasional crystal of some beautiful mineral that most of us have never seen before, though scientists who study minerals could immediately tell what each crystal is.

These stones and crystals would all be stained to some extent by the gummy substances derived from 
rotting animal and plant remains, and the surface of many of them would be covered by a layer of more or less waxy material derived from certain mineral compounds in the soil.

Scattered through the mass of stones we should see pieces of decaying plant and animal remains, like rotten logs in a pile of rocks and gravel. If living plants were growing on the soil, there would be, winding in and out amongst the

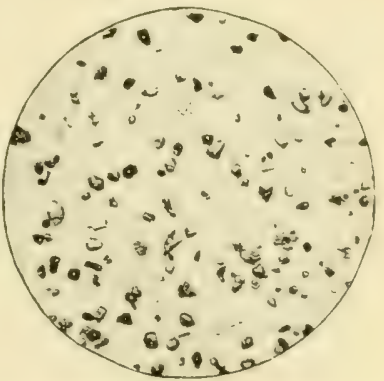

Fig. S. Small sample of suil spread out on a glass plate and photographed. Greatly magnificd.

spongy, water-soaked plant and animal fragments, a network of living plant roots, pushing aside the stones and drinking up the water found in the spaces between them and in the decaying plant and animal matter. Part of the food which growing plants must have would be in solution in this water. Figure 8 gives a greatly magnified view of a small sample of soil spread thinly on a piece of glass, but the magnification is not nearly so great as that we have just been considering.

\section{Experiments}

The experiments outlined at the ends of the various chapters of this book may be carried out by the students at their homes, by the teacher before the class, or, better still, by the members of the class in the presence of the teacher.

I. An important experiment with the slaking of lime and with limewater has already been outlined in the text. This 
is one of the most instructive experiments in the entire realm of chemistry, and should by no means be omitted.

2. Fill a drinking glass as full as possible with ice broken into pieces of not too small a size. Then fill the glass to about one half inch of the top and mark on the outside of the glass the height of the water inside. Remove any pieces of ice that lean so far outward as to rest on the edge of the glass, but leave as much ice projecting above the water as possible. Let the ice stand till it has melted. Note again the height of the water in the glass. When we consider that the entire substance of the ice that at first projected above the water has now been added to the water in the glass, how can we explain the fact that the water is still at the same level?

\section{Things to Observe}

I. If the common rocks of the locality are granitic, or even flint, look for rocks that are crumbling because of the action of the elements on them. Look for broken stones that show plainly in their outer portions the action of the weather. In time these stones will be converted into soil.

2. Pulverize a small stone with a hammer. Compare the resulting material with a sample of soil. Explain the difference.

3. Look for water-worn stones. Where are they most commonly found?

4. Look for pieces of old iron nearly eaten away by rust. What has become of the metal?

\section{Problem}

If a cubical stone 4 inches each way, and weighing 6 pounds, were ground off at the corners till only a 4 -inch sphere remained, what would the sphere weigh? How many pounds of soil material would the portion ground off make?

Note. The volume of the cube is $6+$ cubic inches. The volume of the sphere is $\frac{4}{3} \times 3 \frac{1}{5} \times \mathrm{S}$. The volume of the cube is to that of the sphere as the weight of the cube is to that of the sphere. 


\section{CHAPTER TWO}

\section{DISTRIBUTION OF SOIL MATERIAL}

Is studying this chapter you should refer frequently to the map facing page 32, which shows the location of the various soil areas discussed. Learn where the principal soils occur. See if you can tell from the map what the general character of the soil is in the region in which you live.

\section{RESIDUAL SOILS}

When soil material remains where it was formed by the crumbling of the original rocks of the earth's crust. it is said to be residual. Generally speaking, it is only in the southern half of the eastern United States that residual soils are found, though small areas occur elsewhere.

Residual soils may be divided into three general groups according to the kind of rocks from which they were formed. These groups are discussed briefly in the following paragraphs.

Limestone soils. The map facing page 32 shows that in certain areas the soil was formed from limestone. This soil, as we learned in the first chapter, consists mainly of the insoluble materials that were originally. embedded in the limestone and were left behind when the limestone was removed by solution in soil water; in Chapter One we found that soil water dissolves limestone when it carries carbonic acid gas in solution, which soil water always does to some extent. Soils of this kind are usually, though not always, rather heary, such as clay loam or silt loam. (See next chapter.) They usually hold their fertility well. 
Sandstone and shale soils. Other areas of residual soils were formed by the disintegration (falling to pieces) of sandstones and shales. (Sandstones originate from the consolidation into stone of beds of sand, while shales result from the consolidation of beds of clay.) Find these areas on the map. These soils are mostly rather coarse in texture (more or less sandy), though this is by no means always the case. They are more difficult to keep fertile than limestone soils.

Granitic soils. Lying just east of the Appalachian Mountains is a large area in which the soils were formed by the disintegration of granite and other highly crystalline rocks. Smaller areas occur elsewhere in this country, especially in the mountain states. ${ }^{1}$

Granitic soils are more or less intermediate in character between limestone soils on the one hand and sandstone and shale soils on the other, being often a mixture of sand and clay.

Patches of almost every kind of soil from the lightest sands to the heaviest clays are found in each of the three great groups of residual soils described above, as is indeed the case with those groups to be described later. The type mentioned as characteristic of each area is merely the prevailing one in that area.

\section{TRANSPORTED SOILS}

Soils consisting of materials that have been moved considerable distances from where they originated are

${ }^{1}$ The soils of the West have not yet been sufficiently sturlied to permit their detailed classification. In the mountains the various areas of different soils are also too small to represent on a map of this size. 


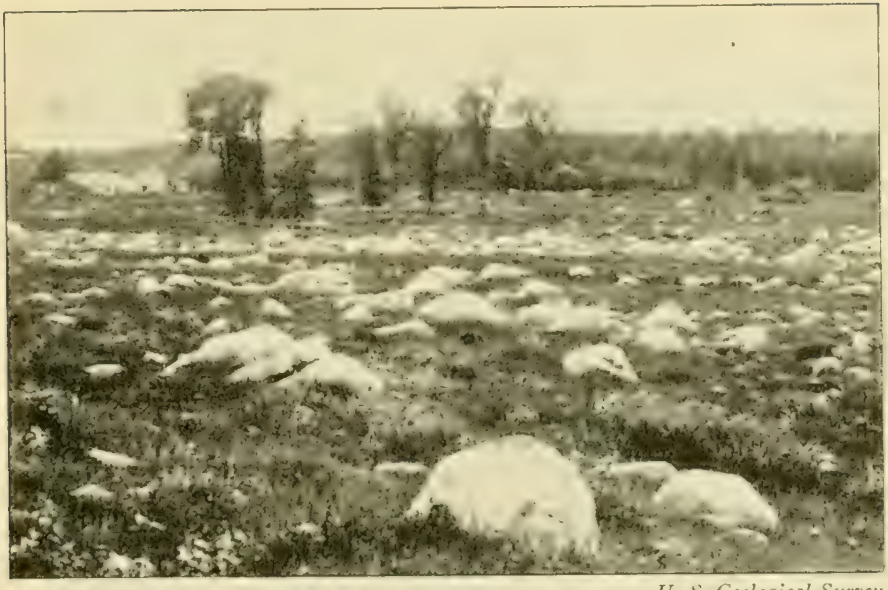

U. S. Geological Survey

FIG. 9. Bowlders deposited by melting glaciers.

called transported soils. The principal areas of transported soils, together with the agencies which transported them, are shown on the map facing page 32 and are listed in the legend to the right of it. The classes of soils of this character are treated briefly below.

Glacial soils. The grlaciers, the action of which was described in Chapter One, transported rast quantities of soil material, often for long distances. When the ice finally melted, the dirt and rocks embedeled in it were left to form the surface soil (Fig. 6. page I5). The layer of material thus deposited varies in depth from a few inches to a hundred feet or more. This ice-borne material constitutes the so-called glacial soils of the country. Note their location on the map. One large area of glacial soil has since been covered by a thin layer of wind-borne material. It is that portion of the 
xolian prairie shown on the map as lying in Illinois, Missouri, and Iowa.

As might be supposed, soils moved about in this manner are very much mixed in character. Usually they contain some gravel, and sometimes large stones like those shown in Figure 9. The stone fences so frequently seen on New England farms (Fig. Io) owe their origin to the great quantity of large stones found on or in the surface of the glacial soils of the region. The easiest way to get rid of these stones was to carry them to the margin of the fields, where they soon accumulated in sufficient quantity to be useful in fence building. Sometimes they are so numerous that it is impracticable to remove them from the land.

While the greater portion of the soils of the glacial region are of excellent quality, there are in some parts of the region vast stretches of thin, sandy soil, very low in fertility unless carefully managed.

Sedimentary soils. When muddy water is poured into a glass or other vessel, the mud, if it is not too finegrained, will gradually settle to the bottom of the ressel and form what we call sediment. There are some notable areas of soil in this country that were deposited as sediment from muddy water. They are discussed in the following paragraphs.

When soil-forming material settles to the bottom of the ocean, it is called marine sediment. A long time ago a wide strip of country which is now dry land, extending from the eastern end of Long Island through where New York City stands and southward around the Atlantic and Gulf coasts to southern Texas, was 


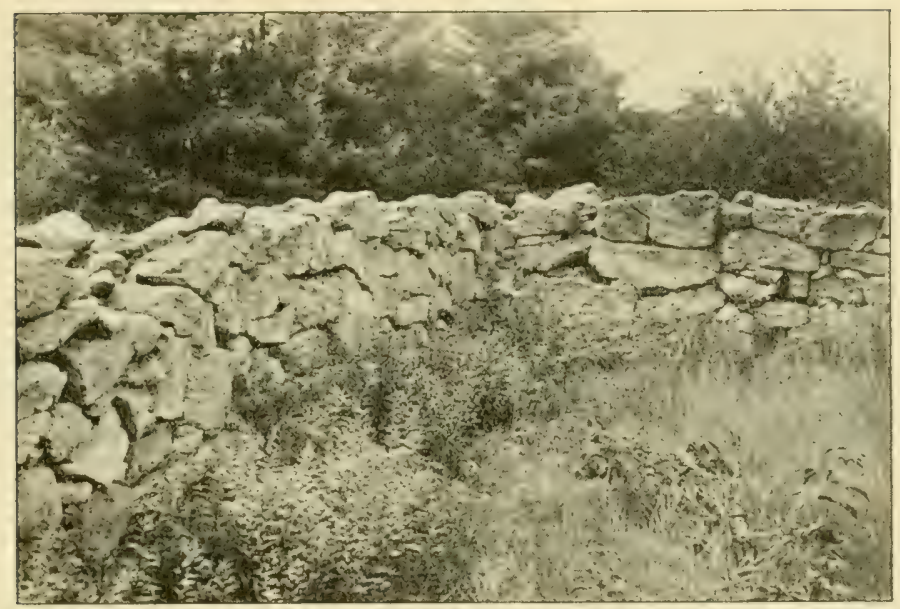

Office of Farm Management

FIG. I0. New England stone fence, built from glacial bowlders. The stones in this fence have been shaped somewhat to fit them for their purpose.

below sea level. This strip constitutes the lower half of the area lying between the Appalachian Mountains and the Atlantic, extending thence westward over a large part of Alabama, Mississippi, Louisiana, and Texas. While it was under water, the rivers which flowed into the sea along this coast carried down vast quantities of sand and finer particles and emptied them into the sea. The currents in the ocean and gulf carried some of these materials long distances before they finally settled to the bottom. Later, when this portion of the continent rose above sea level, the new soil thus exposed represented sediment that had settled in the ocean. The soils in this area are in general quite sandy, though there are some areas of heavy clay and other grades between. At the present time, similar material is accumulating on 
the floor of the ocean everywhere, but mainly around the mouths of rivers.

When soil particles are buffeted about as these have been, all the softer kinds are ground up into material so fine that it finally dissolves in the water and disappears. This leaves a soil composed very largely of the harder kinds of rock particles, chiefly flint, an impure kind of quartz rock, very hard and insoluble. More fertilizers are used in the eastern portion of this area than in any other area of similar size in this country.

Other areas of sedimentary soils, especially in the region of the Great Lakes, were formed by sediment brought by streams into lakes that no longer exist or that have been partially drained by the cutting down of their outlets or by the tilting of the earth's crust under them. These are called lacustrine soils, or simply lake-bottom soils. When not too heavy for good tillage, they are usually very fertile. Most lake-bottom soils are quite level and must be drained before they can be utilized for farming. Note the location of the larger areas of lake-bottom soils on the map (facing page 32 ).

Alluvial soils. Except swiftly flowing mountain streams, nearly all rivers and creeks flow in a level plain between two bluffs. This plain is called a "bottom." The soil in a river or creek bottom consists of materials that have been washed down from the upstream highlands. Such a soil is said to be alluvial. This word is derived from the Latin words which mean " to " and "wash"; this kind of soil has been "washed to" its present location.

With the exception of the Mississippi River bottom 


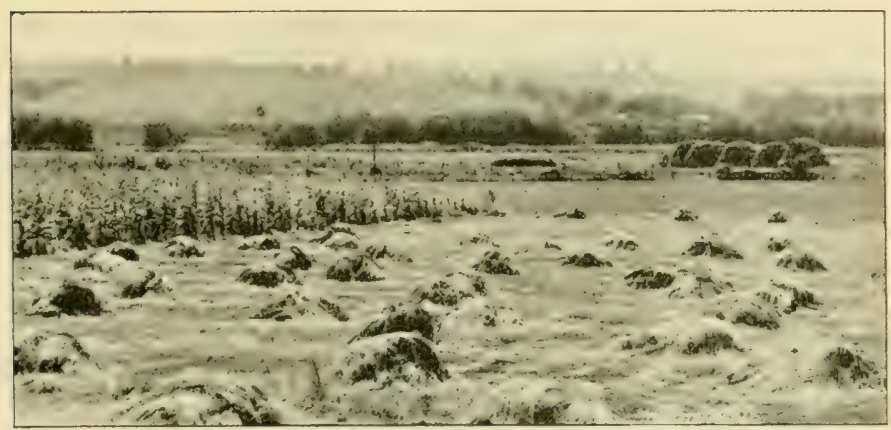

Ofice of Farm Management

FIG. II. The soil in this creek bottom is alluvial. It was washed to its present location by flood waters.

(see map), there are no large areas of alluvial soil in this country, though narrow strips of it occur along the course of nearly every stream. Figure I s shows a creek bottom which is filled with alluvial soil. Such soils are usually quite fertile, provided they are not too sandy and are well drained. It is sometimes necessary to build dikes to protect them from overflow; otherwise occasional crops are lost from floods.

Eolian soils. The ancient Romans thought there was a separate god for everything in nature. They called the supposed god of the winds Eolus. From this name we get the term aolian, which is applied to soils consisting of dust blown to its present location by the wind. These soils, though not covering many large areas in this country, are important. Nuch of the large area marked po on the map facing page 32 is of glacial origin, but the surface has been covered in times past by a thin coat of wind-blown material, so that some geologists call it æolian while others call it glacial soil. 


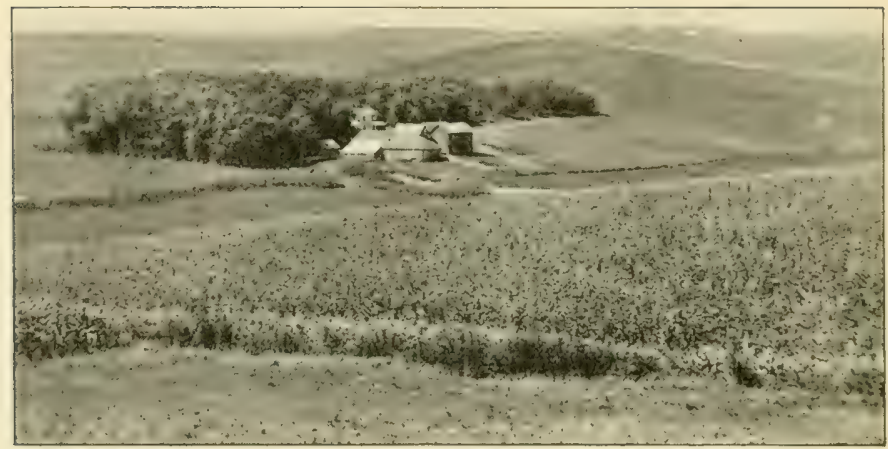

Office of Farm Management (J.S. Cotton)

FIG. 12. Farming scene in the Missouri River Valley, showing wolian soil where the rainfall is not excessive. Some of the best farm land in America.

Eolian soils are very fine-grained, for the dust blown about by the wind consists almost always of fine particles. In some limited areas this wind-blown coating of soil is a hundred feet deep or more, though over great stretches of country it forms only the surface few inches. In fact, the surface soil everywhere consists partly of material deposited by the wind.

The location of the deepest beds of this kind of soil gives a hint of why they were formed. Note the wide strip of æolian soil extending down the east bank of the Mississippi River. In parts of this area the soil is very deep. When the great glaciers covered the northern part of the country, the melting ice every summer turned loose deluges of water to run down this river. The river bottom, which is several miles wide in the North, and much wider in the South, at that time was flooded practically all summer. In winter it dried up, and thus for a time each year the vast ex- 
panse of mud became a tract of dust. The wind, blowing mostly from the west, caught up this dust and carried it over the country to the eastward, where it settled to form soil. Exactly this process is going on now in parts of the Mississippi River bottom, though not on so large a scale. In this country tracts of æolian soil, especially where the soil is deep, usually lie just to the eastward of some river bottom or other source from which dust comes.

Where the rainfall is not so great as to cause much washing, these wind-borne soils are very fertile. Some of our best farming land has this kind of soil. (See Figure 12.) But where the rainfall is very heavy, they wash badly, especially when the original forest covering is cut away and no effort is made to cover the soil with

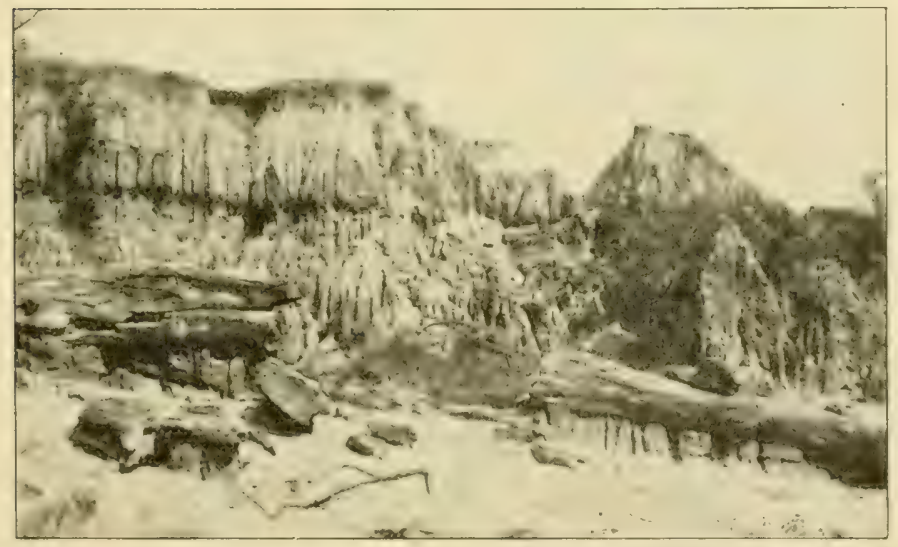

U. S. Geological Survey (Shaze)

Fig. I3. Eolian soil where the rainfall is excessive. Since the timber was cut here, the soil has washed badly. It can be redeemed by planting trees or grass. Petrified logs can be seen in the foreground. 
grass to prevent washing. Figure 13 shows what happens under such conditions.

Eolian soils are easily worked, being very even in texture and not so fine-grained as to be sticky like clay.

Colluvial soils. The term colluital is the last new term we have to learn in this connection. It is derived from two Latin words that mean "washed together." You have all noticed the gravel and dirt that fall from the face of cliffs and from the sides of mountains, and are sometimes washed out considerable distances by torrential rains. Figure I4 shows a mass of such material that has fallen from the face of mountain precipices. Soil that was brought to its present location in this manner is termed colluvial. The only difference between colluvial and alluvial soils is that the latter are the result of the activities of waters confined in narrow river channels, which flow relatively slowly, while the waters that form colluvial soils are not confined in streams and flow swiftly down steep slopes. Colluvial soils are usually coarse and gravelly, merely because the water that forms them moves sufficiently swiftly to carry larger stones and gravel. But some of these soils are of very good quality. Some large areas of colluvial soil are shown on the soil map facing page 32. They lie just eastward of the Rocky Mountains, where the land slopes away from the mountains quite rapidly. Small areas of colluvial soil, usually quite fertile, are found at the foot of almost every hill.

Colluvial action not confined to mountain slopes and bluffs. Where the surface of the land is sloping, every 


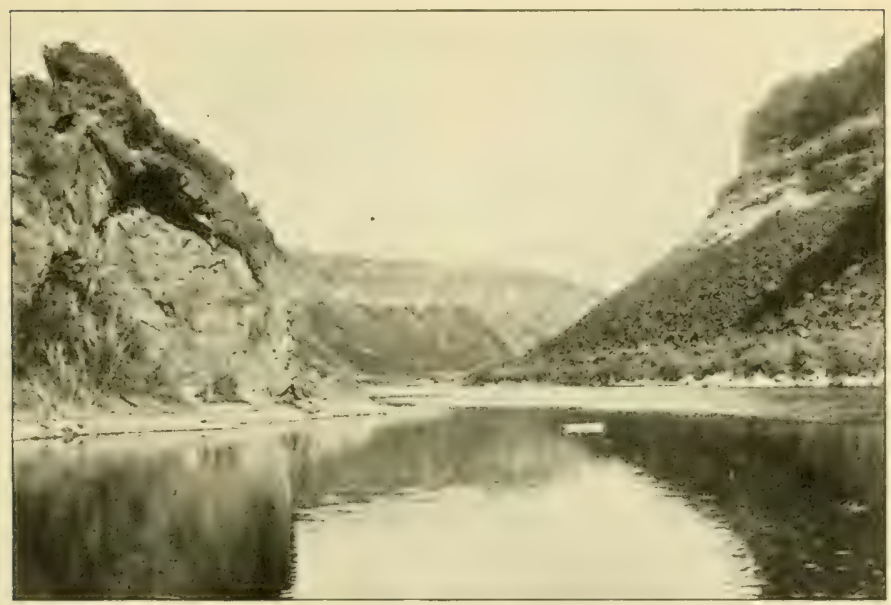

Office of Farm Management (Miller and Thomson)

Fig. 1.4. Colluvial material at the base of precipitous cliffs in the Snake River Canyon of Idaho, near the great irrigation district of Twin Falls.

hard rain moves the surface particles of soil a greater or less distance down the face of the slope. That this movement may become important as a soil moving and mixing agency will become evident when a little consideration is given it. If there are ten hard rain storms in a year, and if each of them moves a particular soil grain a foot down a gentle slope, the grain will move ten feet in a year. In 528 years it would move a mile. How far would it move in 5280 years, if the slope were long enough? It is easily seen that heary rains are an important agency in transporting and mixing soil materials. The soil practically everywhere is thus moved and mixed. What constitutes the surface soil at a given spot is usually not the same material found there a century ago. 


\section{Observation Trip}

After this chapter has been studied, it will help to fasten the facts in mind, and to make them more real, if the teacher and students spend some Saturday afternoon going over the region in the vicinity of the school to look for soil areas that, from their location or character, appear to be of the various classes described in the text - such as residual, glacial, alluvial, colluvial, etc. Unfortunately, only a few of the classes will be found in any one locality; but there will nearly always be at least two classes, one of them alluvial. Along the base of hills and bluffs there will be some colluvial soil, material that has been washed down from the face of the declivity. The map facing this page will show the class of soil prevailing generally in most localities. It will be understood, of course, that there are many small areas of most of the classes of soils that cannot be represented on a small map. Hence, some schools will be situated on lake-bottom soil, for instance, where the map shows only glacial soil, and so for each of the other kinds. If the teacher will write to the State University of his state, the professor of geology will usually be able to tell him the exact kind of soil in his region. 


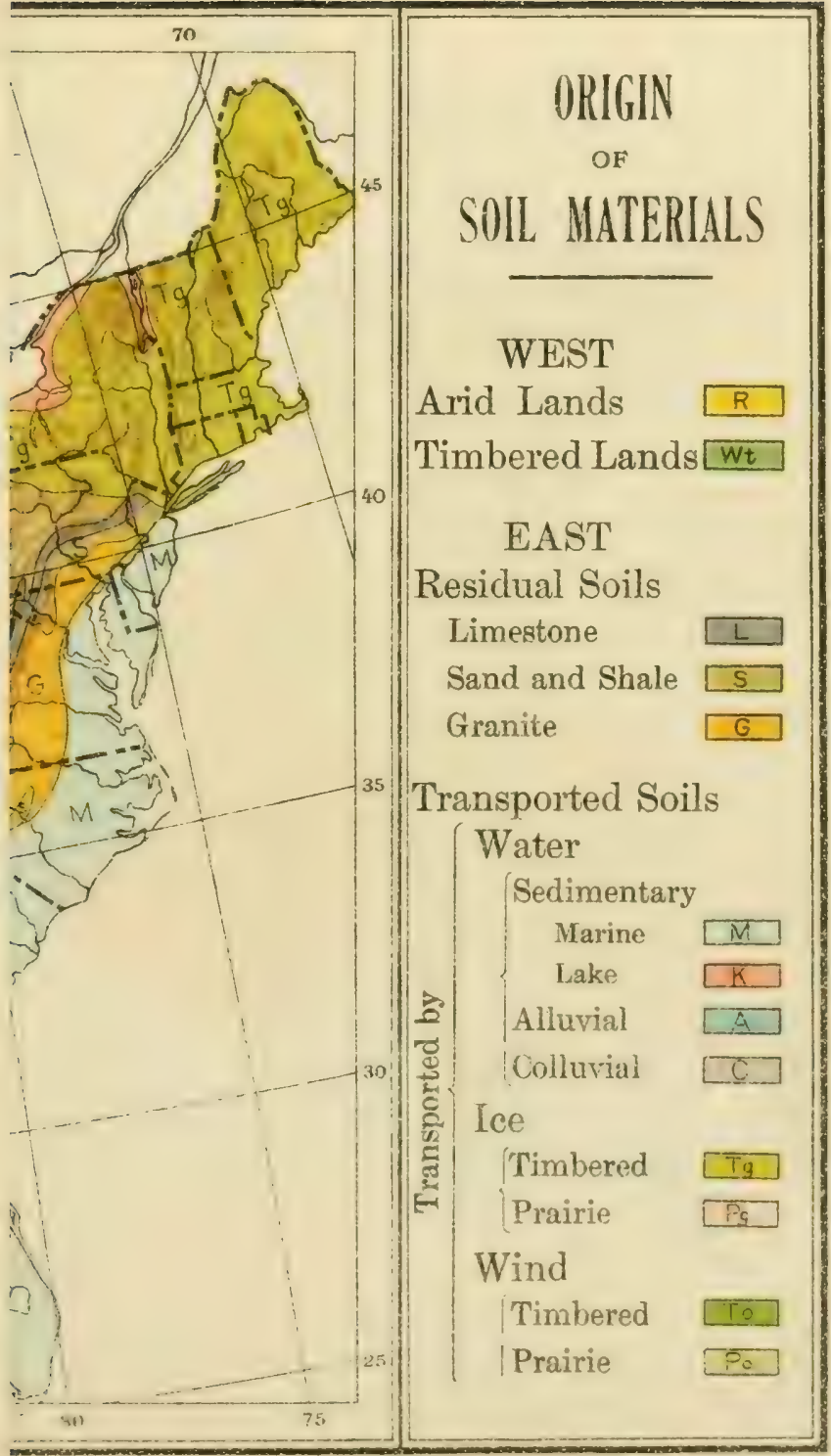





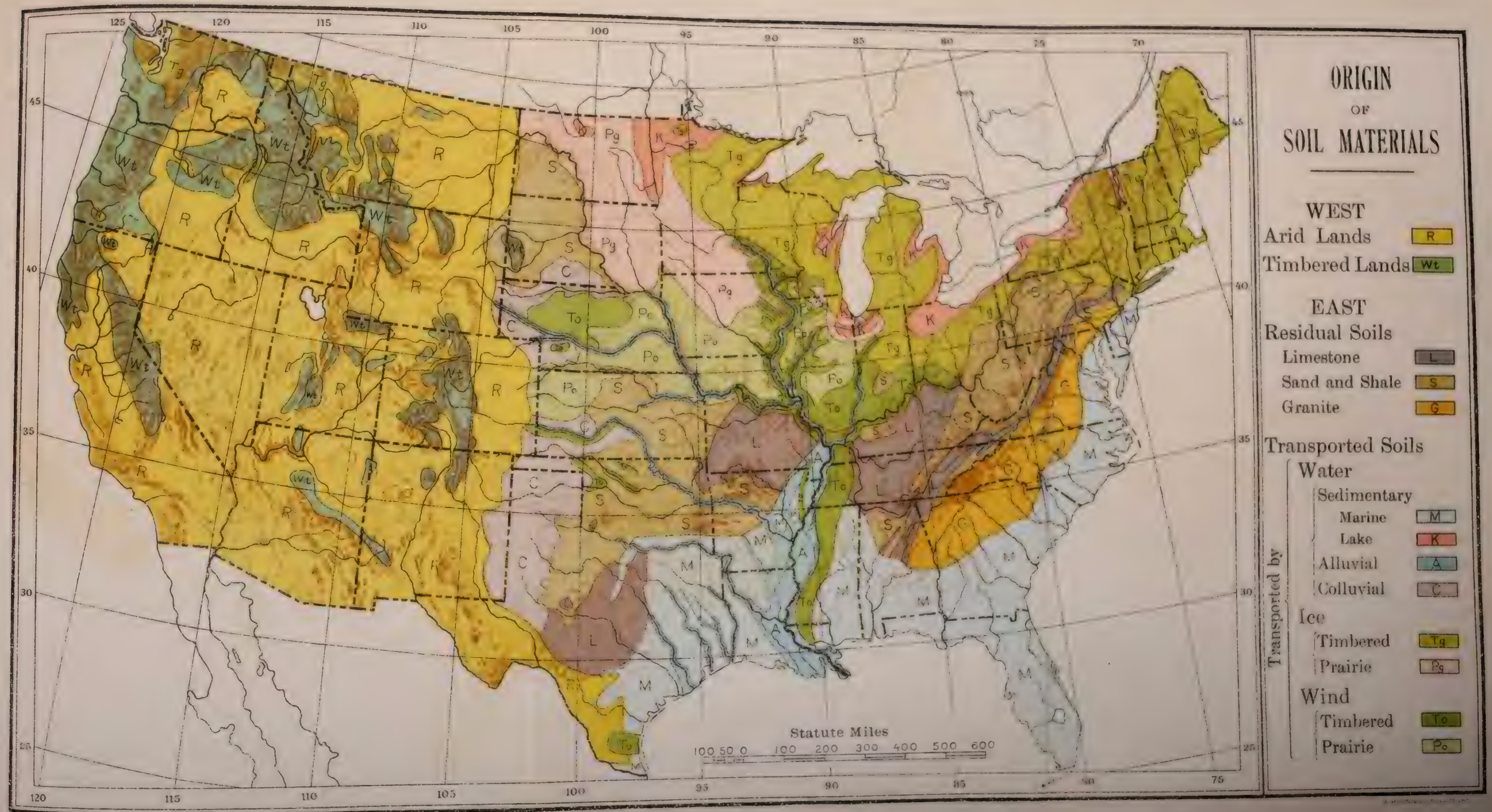




\section{CHAPTER THREE}

\section{SOIL TEXTURE}

THE "texture" of a soil is determined by the sizes of the particles of which it is composed and the proportion that the particles of each size bear to the whole soil. In order to talk understandingly about soil texture, we must therefore learn something about the sizes of the rock particles that compose the bulk of the soil. Soil grains larger than $\frac{1}{25}$ inch in diameter ${ }^{1}$ are called graiel; those smaller than this, but larger than $\frac{1}{500}$ inch, are called sand; those between $\frac{1}{500}$ inch and $\frac{1}{5000}$ inch are called silt; while still smaller ones are called clay. Almost all soils consist of mixtures of soil grains of many different sizes. It is mainly the difference in the percentage of the different sizes that makes the difference in texture between different soils, although the chemical constitution of the soil grains also has its influence on texture. Coarse, sandy soils have mostly large particles in them, while clay soils consist mostly of small particles.

The following table of sizes of soil particles is given merely for reference; it is not worth while at this stage to attempt to learn it in detail. The sizes given are those adopted by the United States Bureau of Soils.

NAMES

Gravel

Sand - coarse

Sand - medium

Sand - fine

Sand - very fine

Silt

Clay
DIAMETER

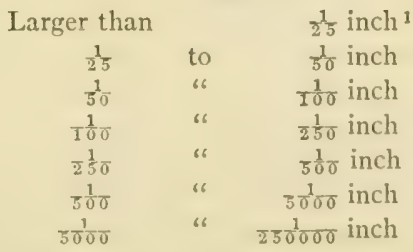

1 More accurately, I millimeter. 
Meaning of the word "clay." The word "clay" is used in two ways. There is a chemical substance called clay, or kaolin. It is the substance used in making fine dishes. It is a compound of aluminum and oxygen, and is dug from clay mines.

In the above table, and throughout this book, the term clay refers only to the size of soil particles, and is applied to any soil that consists largely of particles less than $\frac{1}{5000}$ inch in diameter, without reference to the chemical composition of these particles. It happens, however, that many of these very fine particles do consist of real clay in the chemical sense. Fine-grained soils are called clay because they are tough and sticky (when wet) like real clay.

Soil grains of the next larger size are called silt. Soils composed largely of silt are easy to work, and usually quite fertile except where there is so much rain that the plant food is washed out of them. Æolian soils are sometimes almost pure silt.

The terms graiel and sand are well known and need no discussion here.

Types of soil. The more common names of soil types, based on the general coarseness or fineness of the soil particles, are sand, fine sand, sandy loam, fine sandy loam, loam, silt loam, silt, clay loam, and clay. These are arranged in the order of coarseness, the coarsest first. Any one of these types may have, and usually does have, particles of all sizes in it. It is the proportion of the particles of different sizes that makes the difference between the types.

Any of the above types may contain a good deal of 


\begin{tabular}{|c|c|c|c|c|c|c|c|}
\hline \multicolumn{8}{|c|}{ Per Cent of Gravel. Sand, Silt, and Clay in 20 Grams of Subsoil } \\
\hline Gravel & Coarse sand & Medium sand & Fine sand & Very fine sand & Silt & Fine silt & Clay \\
\hline 0.49 & 1.96 & 10.19 & 27.59 & 12.10 & 7.71 & 2.23 & 4.40 \\
\hline & & & & & & \\
\hline
\end{tabular}

FIG. I5. A sandy soil separated into particles of different sizes. Note that the coarser particles are more abundant than the finer particles. Compare with Figures 16 and 17 .

gravel, giving such type names as gravelly loam, gravelly fine sandy loam, etc. There are also some soils that are given the type name sandy clay, because they consist almost wholly of particles of sand and clay, silt particles being almost entirely lacking in them.

Figure I $_{5}$ show's a sandy soil separated into its constituent parts, each vial containing all the particles belonging to one of the sizes given in the table. Note that the vials toward the left are fuller than those at the right. Figure 16 shows the composition of a good loam soil. It contains some grains of all the sizes, but consists mostly of those of medium size. Figure I7 shows the composition of a very heary clay soil. It contains a very large proportion of the finer particles, but it also has some of the larger sizes.

Two soils of approximately the same texture may 


\begin{tabular}{|c|c|c|c|c|c|c|c|}
\hline \multicolumn{8}{|c|}{ Per Cent of Gravel,Sand, Silt, and Clay in 20 Grams of Subsoil } \\
\hline Gravel & Coarse sand & Medium sand & Fine sand & Very fine sand & Silt & Fine silt & Clay \\
\hline 0.00 & 0.23 & 1.71 & 6.08 & 30.82 & 20.9.2 & 11.21 & 33.78 \\
\hline 83 & $\therefore$ & 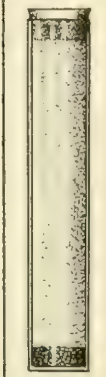 & 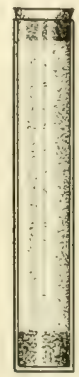 & 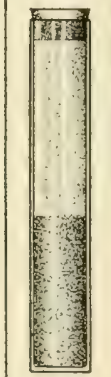 & 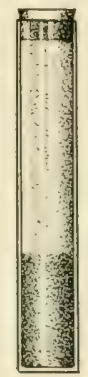 & $\begin{array}{r}\therefore \\
\therefore \\
\therefore \\
\therefore \\
\therefore\end{array}$ & 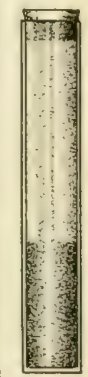 \\
\hline & & & & & & & \\
\hline
\end{tabular}

Fig. 16. A loam soil separated into particles of different sizes. The medium. sized particles are most abundant, though a considerable percentage of "clay" is present.

have different proportions of sand, silt, and clay in them. Thus, one soil might consist mainly of silt and medium sand, while another much like it in texture might consist of silt, very fine sand, and some coarse sand.

There are few places where the soil consists of particles all of about the same size. Eolian soils are an exception. They consist very largely of silt, and have relatively few particles larger or smaller than this. There is also a large area of prairie soil in the drainage basin of the Columbia River east of the Cascade Mountains, the soil of which was made by the action of air and water on great beds of lava of very uniform composition. The wind has also played an important part in shifting the materials composing this soil. The soil grains here are fairly uniform in size compared with most soils, being mostly silt. The usual case is of a soil composed 


\begin{tabular}{|c|c|c|c|c|c|c|c|}
\hline \multicolumn{7}{|c|}{ Per Cent of Gravel, Sand, Silt, and Clay in 20 Grams of Subsoll } \\
\hline Gravel & Coarse sand & Medium sand & Fine sand & Very fine sand & Silt & Fine sitt & Clay \\
\hline 0.00 & 0.08 & 0.19 & 0.53 & 1094 & 19.02 & 4.67 & 51.75 \\
\hline & & & & & & & \\
\hline
\end{tabular}

FIG. I7. A clay soil separated into its constituent particles, by sizes. The finest particles are most abundant. All these soils (Figs. 15, 16, and 17) have some particles of all the sizes.

of particles of practically all sizes, with some sizes much more abundant than others.

Loams are intermediate between sandy and clay soils. They usually contain a fair proportion of particles of all sizes, with those of intermediate sizes predominating.

Soils in which the content of vegetable matter determines the type. Low, wet soils often contain such large quantities of vegetable matter as to determine their character. If the land is actually water-soaked, it is called swamp land, no matter what its composition. In some places, especially in New England, and generally in northern Europe, such land is called " meadow," the wild grasses on it frequently being cut for hay. If drained, or partially drained, and if the vegetable matter is pretty well rotted, the type is muck. If the rege- 


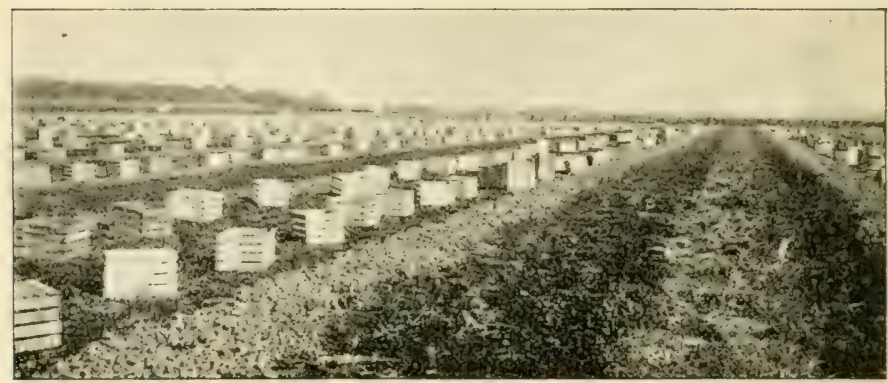

Horticultural Investigations, U.S.D.A.

FIG. IS. A field of onions being harvested on muck soil in Ohio. A typical muck soil crop.

table matter is still more or less fibrous (only partially rotted), we have peat.

Muck lands, when well drained, can be made to produce good crops. They are especially adapted to the production of onions, cabbage, celery, and peppermint. Figure 18 shows a field of onions on muck land in Ohio. Considerable areas of such land in New York, Ohio, Michigan, Indiana, and some other states are devoted to growing vegetables for market. Figure i9 shows a truck-farming scene on muck land in the state of New York. The area of land of this character in these states is so large that it cannot all be used in this manner; there would not be sufficient market for all the products. Fortunately, good crops of corn and hay can be grown on muck. Oats often grew too rank on such soil unless it is unusually well drained.

Muck soils respond to manure in a remarkable manner. Fertilizers containing potash are especially good for them. When muck soils become dry, they become very light 
in weight, because of the large amount of regetable matter they contain. Under such conditions much of the soil is blown away unless measures are taken to prevent it. Rows of trees are sometimes planted on such soils as a means of breaking the force of the wind and thus reducing the loss of surface soil from wind action. The land shown in Figure 20 is thus protected.

Meaning of "heavy" and "light" as applied to soils. Coarse-grained soils are more or less loose in texture, and are easy to work. Hence they are called light soils. Fine-grained soils are usually tough when dry, and sticky when wet. This makes them hard to plow. Hence they are called heary soils. The words "light" and "heavy" used in this connection have no reference to the weight of the soil material.

Effect of plowing heavy soils too dry. If heary soils are plowed too dry, they break up cloddy, as is seen in Figure 2I. This does no particular harm, provided

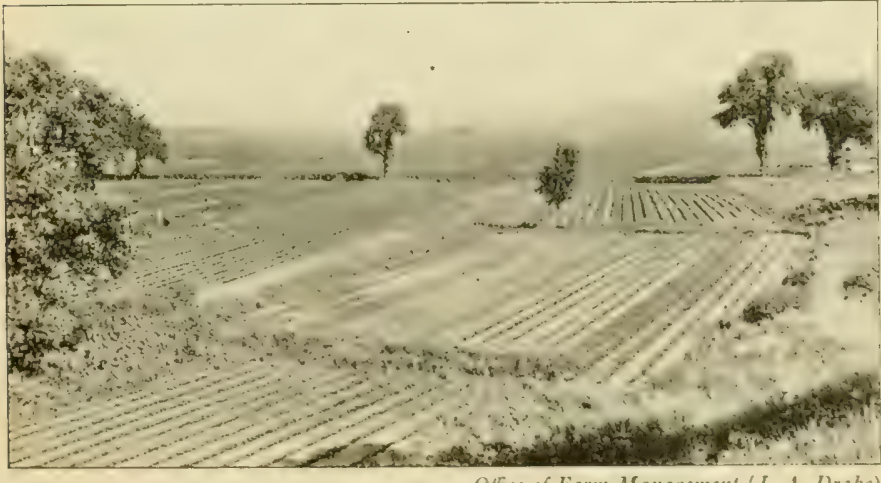

Office of Farm Managemenl (J.A. Drake)

FIG. I9. Truck farming on muck land in New York. 


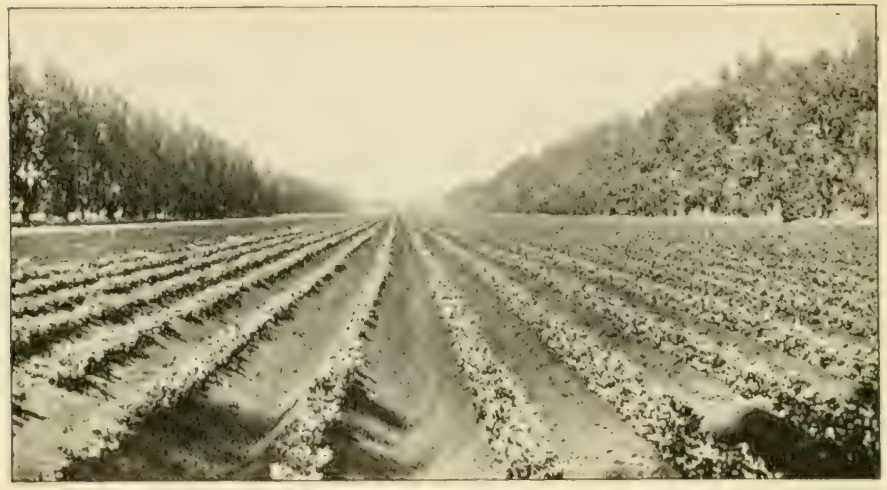

Office of Farm Management (J.A. Drake)

Fig. 20. Rows of trees used as windbreaks on muck soil. They tend to keep the light-weight soil from blowing away.

there is time before the crop must be planted for plenty of rain to come and crumble the clods. Unless rain does come, it is practically impossible to make a good seed bed of a cloddy soil.

If a good growth of some green crop is turned under in the plowing, the soil is full of living roots which rot rapidly and thus leave channels through which the water from the first good rain can enter the clods and cause them to fall apart.

In plowing stubble land for fall-sown wheat, the plowing should never be delayed merely because the soil is dry and breaks up cloddy. It is important that this plowing should be done as early as possible after harvest. The reason for this will be given later. Fortunately, the long season between plowing for fall-sown wheat and seeding time gives a chance for rain to break down the clods. 
Effect of plowing a heavy soil too wet. Plowing a heavy soil too dry does no permanent injury; but plowing such soils too wet is quite a different matter. In a dry soil the gummy substances which are founc in small quantity on the surface of the soil grains become hardened, so that wherever two soil grains touch each other they stick together more or less firmly. This is why a heavy soil is hard to plow when dry, and still harder to pulverize into fine dust. But when the soil is full of moisture, the gummy substances in it become softened, so that the soil grains move easily on each other. If stirred about much when wet, as would be the case in plowing, for instance, the soil particles slip in between each other and become closely packed together. In this condition the soil is said to be

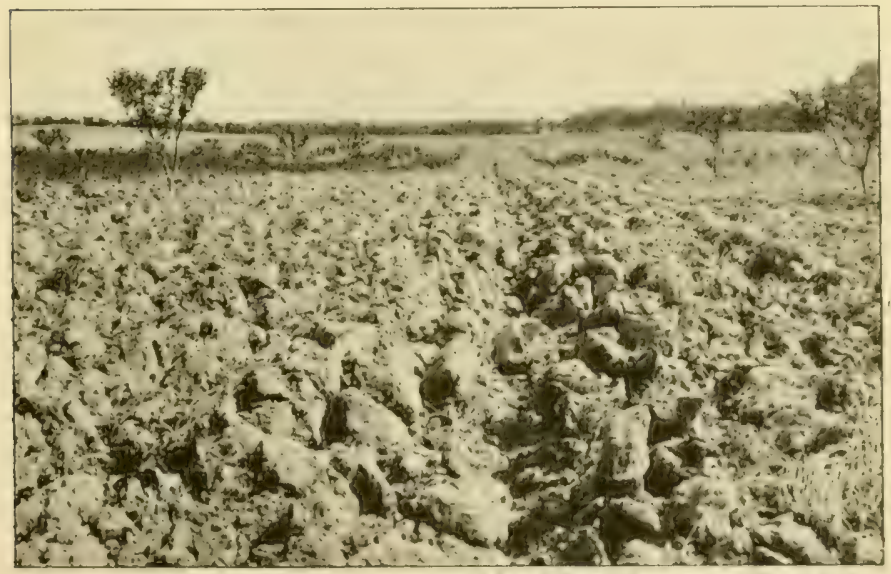

()ffice of Furm .Hanasement (II, A. Miller)

Fig. 2r. A heavy soil plowed when very dry. A crop of green rye has been turned under here, and these clods will melt away at the first good rain. 


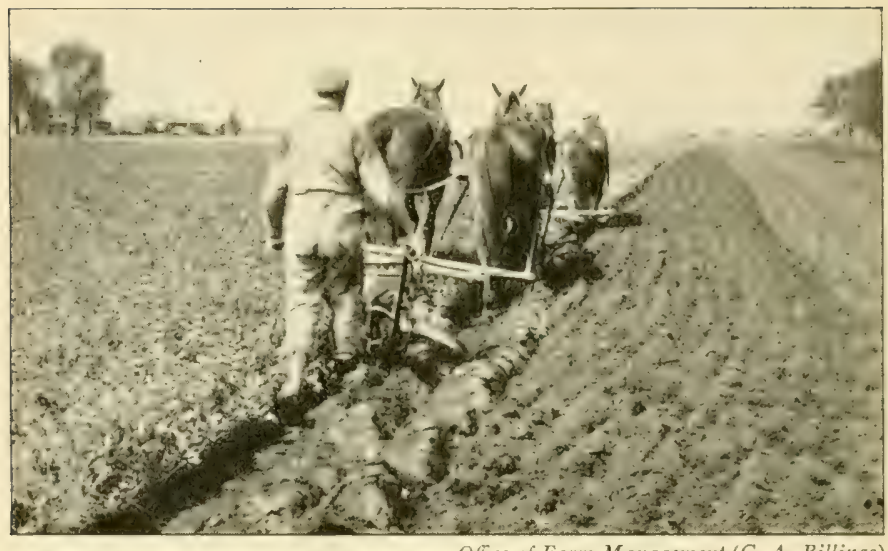

Office of Farm Management (G. A. Billings)

FIG. 22. Sandy loam potato soil in central New Jersey. The last two furrows show how a soil looks when plowed wet. This does little or no harm if the soil is sandy, but would be ruinous to a heavy clay soil. Note the fine pulverization of the furrow slices turned up before the shower.

"puddled." If the soil dries in this condition, then air and water cannot circulate freely through it, and it becomes a very poor home for plant roots. For this reason a heavy soil should never be plowed when wet, for to do so might render it practically useless for the entire season, or even longer. Sandy soils are not injured in this manner.

Figure 22 shows how a soil looks when plowed too wet. This farmer had started in to plow his field, when a shower of rain came up and stopped the work. He was just plowing the second round after the shower when this picture was taken. Note the sleek surface on the freshly upturned furrow slice. It happens that the soil in this picture is a sandy loam in the famous potato region of central New Jersey, and no harm is being done 
to the soil. But if this farmer had been plowing a clay or clay-loam soil, he could not have gone to work again so soon after the shower without injuring the soil. The fact that he is plowing under a nice growth of young clover also tends to prevent injury. The soil is full of clover roots, and when these rot, which they will do in a few days, they will leave channels in the soil through which water can readily enter and break down the clods. Note how finely the furrows are pulverized that were plowed before the shower. Clay soils seldom, if ever, pulverize as finely as this.

The effect of puddling in a clay soil may be seen for many years when an old roadway in such soil is plowed up and put into cultivation. Its location can easily be seen in the growing crop, which for the first few years does not grow half as tall as that on each side of the former roadway.

Ideal condition for plowing. In the case of sandy soils, it makes little difference as to their moisture content when they are plowed. They can be worked wet or dry, with little or no injury. But in the case of heavy soils, - and the heavier they are the more important this is, - they should never be plowed when wet. A heavy soil is in proper condition for the plow when it contains just enough moisture to crumble easily. This can be judged by taking a lump of soil in the hand and crushing it. If it is not easily broken up and pulverized, it is too dry; if it crumbles easily, it is just right; but if the soil sticks together in a moist lump after being squeezed together in the hand, it is too wet. 


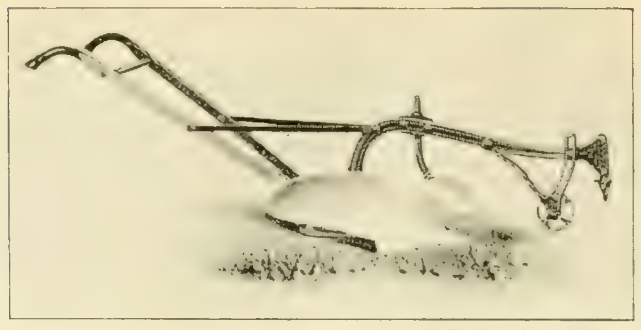

Oliver Chilled Plow Works

FrG. 23. A moldboard plow, the common type of plow in the United States.

Relation of texture and moisture to other tillage operations. What has been said above about plowing applies also in some degree to other tillage operations, such as harrowing and cultivating. If the soil is sandy, tillage operations may begin almost immediately after rain ceases. But if the soil is a clay or clay loam, or other type of heavy soil, it is necessary to wait till it has dried out considerably before starting the harrow or cultivator. There is no objection to harrowing or cultivating a heavy soil when it is $d r y$, for such operations do not tend to form clods; they tend rather to break up the clods.

Continued wet weather has a tendency to overcome the effect of puddling in the soil, but since one cannot depend on the weather, it is never safe to puddle a heavy soil.

Relation of soil texture to type of plow. There are certain soils that are so heavy and sticky that an ordinary moldboard plow, like that shown in Figure 23, cannot be used on them. The dirt sticks to the surface of the moldboard instead of slipping over it as should 
be the case; that is, the plow does not "scour." In these soils farmers generally use disk plows, like that shown in Figure 24. Disk plows pull more heavily than moldboard plows, and are hence not generally used where the moldboard plow is satisfactory.

The moldboard of a plow may be made of cast steel, or it may be forged; that is, worked into shape by simply heating the steel red hot. For some reason not understood, dirt slips over the surface of a forged moldboard more readily than it does over that of a cast moldboard. For this reason plows with cast moldboards (the so-called " chilled" plows) cannot be used on certain rather heavy types of soil, such as silt, silt loam, etc. Chilled plows are much used on soils that contain more or less gravel, for almost any plow will scour in such a soil.

Relation of texture to character of soil mulch. When the surface of the soil has been well pulverized and made loose, the soil is said to be covered with a soil mulch,

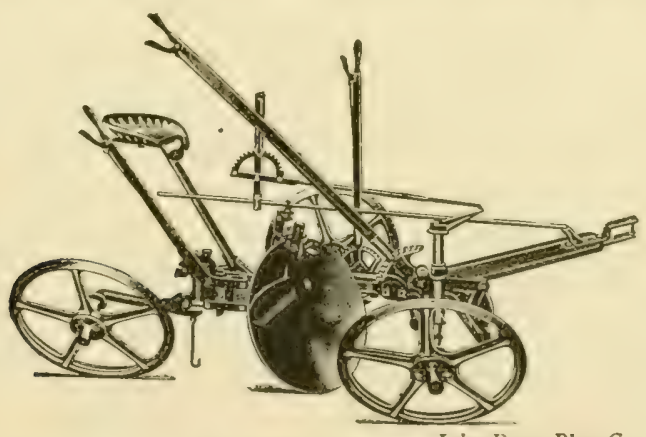

FIG. 24. A disk plow; used where the soil is so sticky that it will not "scour" on a moldboard plow. 


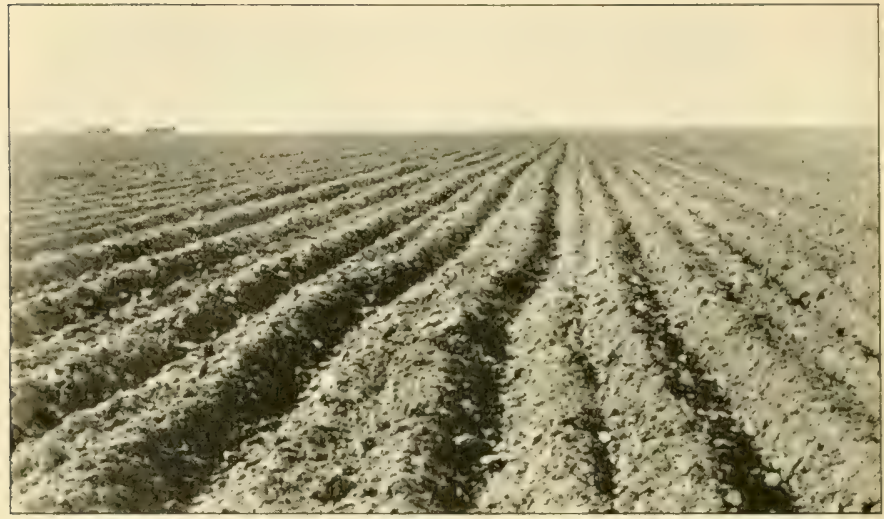

Office of Farm Managenent

FiG. 25. A fallow field of silt loam soil in western Kansas. Note that the surface soil consists of small clods, an ideal mulch in a windy country.

or dirt mulch. When a clay soil is pulverized, it consists of many small clods with very little fine dust between them. (See Figure 25.) This is an ideal dirt mulch for a windy country. In the dry-farming country farmers like to get this kind of mulch, for the clods will not blow away as dust will. As we pass from clay soil to clay loam, the amount of dust in the dirt mulch increases. It is still more in a silt loam, while in a good loam a well-made dirt mulch consists mostly of dust with a moderate proportion of small clods in it. It is only when we come to sandy loams and soils still more sandy that we can make a mulch entirely of fine dust. A few turns with the harrow would make a fine dust mulch on a soil like that shown at the extreme right in Figure 22.

Relation of texture to fertility of the soil. Generally speaking, the heavier a soil is, the more fertile it is, 
provided it is not so heavy and fine-grained that air and water cannot readily circulate through it. The reasons for this will be given later. Most soils are fertile enough when first put into cultivation, but sandy soils wear out quickly unless special pains are taken to keep up their fertility.

\section{Things to Observe}

Soil differences. One way to test the texture of soil is to take a small sample of the dry material between the fingers and rub them together. In this way it is easy to distinguish between a sandy soil and a clay soil, for the clay soil contains a large proportion of very fine particles, while the sandy soil consists mainly of larger particles.

Examine all the different soils of the community and see if you can at least roughly classify, them as to texture. Note the appearance of different soils when freshly plowed. Clay soils, or other heavy soils, do not crumble into as small particles as do sandy soils.

Note the differences in the colors of the various soil types of the community. Common soil colors are gray, light brown, dark brown, black, yellowish gray, and red. Red color in a soil is due to certain compounds of iron. All soils contain iron, but not always in red-colored compounds. Black color in soils is due to the presence of certain substances derived from decaying vegetable matter. Muck soils are usually black. Note especially the difference in color between the best and the poorest soils. Rich soils are usually, though not always, darker in color than poor soils.

Fertility of different soils. If there are two or more distinct types of soil in the community, get all the information you can about the crops to which each type is best adapted. Determine the average vield of each crop on each of the soil types on which it is commonly grown in your locality. 


\section{Experiment}

Fill a glass fruit jar about one fourth full of ordinary soil. Add sufficient water to fill the jar. Then place the rubber ring in place and fasten on the lid. After shaking the jar vigorously for a minute or two, set it on a table and let the soil settle to the bottom. This will bring about a rough separation of the various-sized soil particles, the largest at the bottom, with the finest on top. The separation into sizes will not be at all complete, but the experiment will be instructive. It might be repeated with several different soil types if they are available. 


\section{CHAPTER FOUR}

\section{MOISTURE IN THE SOIL}

Origin and meaning of the word "capillary." In the Latin language, from which we get so many of our words, the word capilla means "hair." Hence, when the space between two objects is so small that it may be compared with the thickness of a hair, it is called a capillary spacc. In these small spaces all kinds of liquids show properties that are not easily observable elsewhere, and their behavior in these tiny spaces is called capillary action. But careful observation will show that the properties of liquids which cause these capillary actions may be observed to some extent when a liquid is placed in a vessel of ordinary size.

Examples of capillary action. Partially fill a clean drinking glass with water. Note how the water rises at the edges where it touches the glass. If the inner surface of the glass is greasy, the water will turn down at the edges. Coal oil in a lamp wick rises by capillary action. Place a lump of sugar in a dish with a shallow layer of water in it. Note how the water rises into the lump. A small clod of earth may be used in this last experiment. These are all examples of capillary action.

Cause of capillary action. Did it ever occur to you to ask why it is that drops of water tend to be round? Water, like all other substances, is composed of molecules, and these in turn of atoms. It has already been stated (page 2) that atoms have very strong attraction for each other. Molecules also attract each other. but with less force than atoms. Imagine, then, a large number of water molecules as close together as they can 
get; each is attracted by all the others. The result of all these attractions tends to bring each particle to the center of the group. Obviously they cannot all reach this point, but each gets as near it as possible. By arranging themselves in the form of a sphere, the arerage distance of each particle from the center they are all seeking is less than in any other arrangement. Hence a drop of any liquid tends to be spherical in form.

There is also considerable attraction between the particles of water and those of glass. Hence water sticks to glass when brought in contact with it. This is only another way of saying that glass becomes wet when water touches it. Beeswax does not thus become wet even when held under water, for the attraction between the particles of beeswax and those of water is less than that between the particles of water themselves. If a drop of water is placed on a perfectly clean surface of glass, the water will spread out over the glass until it becomes a very thin layer, but it will not thus spread out on beeswax, nor on paraffin or tallow. Water. will even run uphill to spread out over a clean glass surface, because the attraction between glass and water is so great.

In the experiment with water in a drinking glass, the water at the edges where it touches the glass spreads upward over the surface of the glass. But water particles attract each other. Hence particles (molecules) of water not directly in contact with the glass, but lying next to those that are, are drawn upward also. These pull up others a little farther away, and so on, so that 
the water turns up noticeably near the edge of the glass.

The attraction between the particles of water is not strong enough to lift all the water in a large vessel, but if the glass were of capillary size, and open at each end, and if the bottom end were placed in water, then the water would crawl up the little glass tube several inches. By heating a glass tube till it is soft, it can be

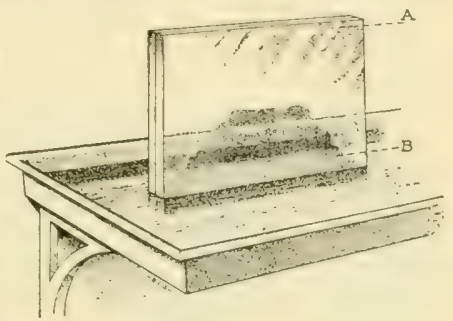

Fig. 26. Two clean glass plates pressed together, with their lower edges in water. The water is drawn up between the plates by capillary action. The cleaner the plates and the closer they are pressed together, the higher the water will rise. $A$, glass plates; $B$, capillary layer of water.

drawn out into a little tube much smaller than a hair, and in such a tube water will rise by capillary action several feet.

A very good way to demonstrate the capillary action of water is to press together two clean, flat pieces of glass, holding the lower edges of the pieces in water (Fig. 26). The capillary force, which is merely the attraction between the glass and the water (involving also the attraction of the water particles for each other), will draw the water up between the plates of glass, several inches if the glass is clean. The closer the glass plates are pressed together, the higher the water will rise between them. This experiment is very instructive, and should not be omitted. It will help you to understand some of the things that follow.

The coal oil in a lamp wick is drawn up in the small 
spaces between the threads of the wick, and even between the fibers of each thread, just as the water is drawn up between the gląss plates in the above experiment.

Another instructive experiment showing capillary action is performed as follows: place a small dish, such as a mush bowl, in a larger dish, and fill the smaller dish about half full of water. Now place a piece of clean cotton or linen cloth over the edge of the smaller dish so that one end of the cloth is in the water and the other end hangs down till it touches the bottom of the larger dish. The entire quantity of water will slowly crawl up the cloth and pass over into the lower vessel. The movement of the water will be slow, and it may take a day or two for all of it to disappear from the upper vessel, but the experiment is well worth trying. Can you explain what happens in this experiment?

Amount of capillary space in the soil. In Chapter One we tried to picture what a cubic inch of soil would look like if it were enlarged until it became a cubic mile. It would look like a lot of very dirty rocks, with rotten logs (dead plant roots) here and there among them. Between the rocks would be a considerable amount of open space, occupied partly by water and partly by air. The amount of this open space would depend on the size, shape, and arrangement of the stones.

Let us now think of the soil as it actually is. If it is very dry, nearly half of the space the soil appears to occupy is really open space filled with air, with a thin layer of water adhering to the surface of each soil grain. 
Since the grains are of many sizes, and are irregularly arranged, the capillary spaces in the soil are very irregular.

How water behaves in the capillary spaces of the soil. Nearly all kinds of rock particles attract water, just as glass does. How, then, would water behave in the capillary spaces of the soil? When water is absorbed into a perfectly dry soil, the first thing that happens is that the water slowly spreads over the surface of every soil grain, just as it spreads over a clean glass surface. Where the grains touch each other, or come close together, the water

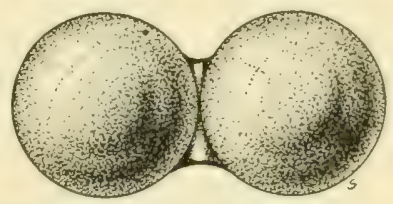

FIG. 27. Two glass spheres in contact with each other, or nearly so, with a drop or two of water between them. Note how the water collects about the point where the spheres come closest together. Water thus collects at the points where soil grains touch each other or come very close together. would collect in the narrowest parts of the spaces between them. If two glass marbles are held in contact or very close together, and if a drop or two of water be placed between them, the water will assume the form shown in Figure 27. Try this experiment. The marbles need not be of glass, provided they are of material that water will stick to as it does to glass.

When the amount of water in the soil is sufficient in quantity, after forming a film over the surface of all the soil grains the surplus collects in a similar manner about the points of contact between soil grains, or at points where the grains come close together. As the amount of water in the soil increases, the film surrounding each soil grain becomes thicker, and the amount collected at points of contact between soil grains in- 
creases. Finally, when the soil becomes completely saturated with water, all the air is driven out, and all the open space in the soil becomes filled with water. It is only by pouring water on to the soil that we can completely fill the open space in it with water, for capillary action will not draw so much water as this into the soil.

What happens when a very wet soil is drained. If we give the water in a water-soaked soil a chance to run off, it will run down through the soil, emptying the larger capillary spaces and drawing the air in after it. But it will not run out of the very small spaces such as are found at points of contact between soil grains. The attraction of the water for the rock particles is sufficient to hold a considerable amount of water in these small spaces in opposition to the force of gravity. The amount that thus remains is the same as the amount the soil will absorb by capillary action. Even if we could apply some force to drive this capillary water out of the soil, there would still be a thin film of water over the surface of every soil grain. It is only by long-continued drying, at high temperatures, that the last bit of water can be taken out of a sample of soil. The driest dust contains some water.

Difference in capillary action in moist and in dry soil. A very interesting experiment is to take two clods of the same kind of soil, one very dry and the other moderately moist, stand them in a shallow dish, and pour a little water in the dish. The water will at once rise by capillary action into the moist clod, but it will rise very slowly in the dry one. In the moist clod, every 
soil grain is already wet, and the water in the dish is quickly drawn into the capillary spaces within the clod. But in the dry clod the soil grains must first become wet by the slow creeping of the water over them.

A soil that is in proper condition for plowing, or for other tillage operations, has a film of moisture over each soil grain, with more or less additional water collected in the narrow places, while the remainder of the open space in it is filled with air. In a coarse, sandy soil, the proportion of air is greater and the proportion of water less than in a fine-grained soil, assuming that both soils are in proper condition for working.

Difference in capillary action in compact and loose soil. Take an ordinary plate, or some similar vessel, and place in it a clod (not too dry) and also a pile of loose dust of the same kind of soil as the clod. Pour a little water into the plate. Note the difference in the behavior of the water in the two cases. The capillary spaces in the clod are small, and when the soil grains have once become wet, the water rises readily into the clod (unless it is too fine grained). But in the loose dust the spaces are mostly larger, and the water does not completely fill them. Weight for weight the clod will take up more water than the loose material. Even the clod will still have some air in it after it has absorbed all the water it will.

Behavior of water in different kinds of soil. In a very loose, sandy soil the particles and the spaces between them are relatively large, and such soils will not hold much water by capillary force. But in a heary clay soil the capillary spaces are both very small and 
very numerous. Water is slow in getting into such a soil, but when it does get in, it is difficult to get out. The heaviest clays hold their moisture so firmly that plants trying to grow on them may actually die of thirst, surrounded by an abundance of water. The best soils are intermediate between clay and sand. They hold a good deal of water, but give it up readily to growing plants. The very best soils are those that approach clay in texture, but have capillary spaces large enough to permit the water in them to move readily. Silts, silt loams, and the lighter clay loams are of this kind.

Relation of decaying vegetable matter to soil moisture. You have all seen how a sponge takes up water, and how easy it is to squeeze most of the water out of it again. Decaying vegetable matter in the soil acts in the same way. When rain moistens the soil, these half-rotted fragments become filled with water, but give it up readily to near-by plant roots, which must take up large quantities of water to keep the plants above in good growing condition. The decaying vegetable and animal matter, or humus, of the soil, although constituting only a small part of the whole, is by far the most important part of the soil from the standpoint of the farmer. A farmer who does not keep his soil well stocked with humus should not expect to grow good crops.

Hard and soft water. The soil contains small amounts of many substances that dissolve in water just as salt and sugar do, though usually not so readily. These substances come from the disintegrating rock particles 
of the soil. Water which carries in solution a considerable quantity of these substances is said to be " hard." When it is very free from mineral matter, water is said to be "soft." Rain water is soft, but water in the soil is nearly always more or less hard. Where limestone rocks come in contact with the soil water, which always contains more or less carbonic acid gas in solution, the water dissolves some of the limestone and becomes quite hard.

You have doubtless noticed that kettles in which water is frequently boiled have a tendency to become coated on the inside with a kind of "scale." This scale is merely the mineral matter that was held in solution by the water. The inside of steam boilers becomes so thickly coated in this manner that it is necessary to clean them out once in a while. "Manholes" are made in boilers to make it possible to get at the scale. If nothing but clean rainwater is used in a boiler, no scale forms in it.

Alkali. In dry countries, where there is seldom enough rain to wet the soil more than two or three feet deep, a great deal of soluble mineral matter collects in the soil from the continued disintegration of the soil particles, there being too little rain to wash this mineral matter down to the water table, which may be at a great depth in the soil. When rain does fall on such soil, or when irrigation water is applied to it, the water sinks into the soil a few inches or a few feet, dissolving all the soluble matter it finds. At once this water begins to evaporate at the surface of the soil, and this evaporation continues until practically all the water has been brought back 
to the surface by capillary action and there passed off into the air as vapor. As it evaporates, the soluble minerals it contains are left at the surface and constitute the much-dreaded alkali which irrigation farmers know so well. In the chapter on irrigation we shall learn how to control alkali.

\section{AIR IN THE SOIL}

When a dashing rain comes after a long dry spell, if you will watch carefully shortly after it begins to rain, you will see a great many air bubbles coming out of the soil. These bubbles are made of the air that was in the capillary spaces of the dry soil. The air is driven out of the soil in proportion to the amount of water that enters. The air in the capillary spaces of the soil is never absolutely still. In clear, dry weather the air above ground actually blows into the soil, just as it blows into the mouth of a cave. But just before a big storm the air blows out of the soil as it does out of the mouth of a cave. Thus the soil may be said to breathe, though it takes very long breaths, sometimes a single breath continuing for a week or more. What this breathing means to the farmer will appear later when we have learned how plants live.

\section{Experiments}

Several experiments have already been described in the text. These should all be performed either by the class or by the teacher in the presence of the class.

r. Amount of capillary space in the soil. Fill a glass or cup with dry sand. Now find how much water can be 


\section{Moisture in the Soil}

poured into the sand. This gives an idea of the amount of space for air and water in the soil. The experiment may be repeated with a sample of good soil, as dry as can be obtained. Note the bubbles of air that rise from the soil in the cup as the water soaks in.

2. Scale in boilers and cooking vessels due to "hardness" of water. In a clean cooking vessel boil a quart or more of clear rain water until the water is all gone. Does it leave any scale on the inside of the ressel? In the same vessel boil in the same manner a like amount of clear water from a well or spring. The "harder" this water is, the better the experiment will succeed. Does it leave any scale? The hardness of water may be roughly estimated in this manner.

3. Why alkali collects at the soil surface. Soak a soft pine board overnight in strong brine (made by dissolving salt in water), and then put the board in a dry place for a day or two. Why does the salt appear on the surface of the dry board? Where was this salt when the board was first taken out of the brine?

4. Soil air. Pour a bucket of water on a level, dry soil surface. Explain the bubbles that appear. Watch for the same thing when a dashing rain falls on dry soil, immediately after the rain begins. 


\section{CHAPTER FIVE}

\section{TILLAGE}

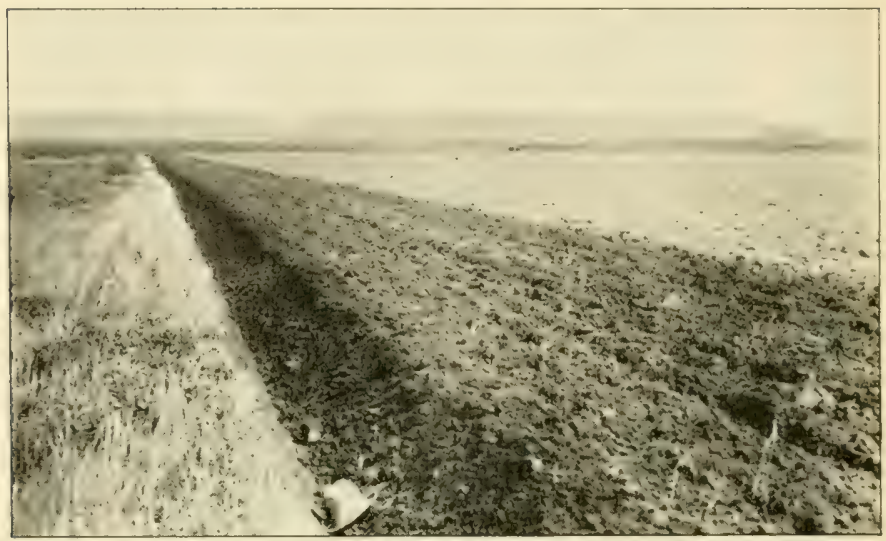

Office of Farm Management

Fig. 2S. Good work with the plow. A scene in the Western Plains region.

THE objects and methods of tillage are here set forth, not in the order of their importance, but in the order in which the tillage operations usually occur in growing crops.

First object of tillage. The first object to be accomplished by tillage is to loosen up the soil so that air and water can move freely through it. Plant roots must absorb from the soil from 300 to 800 pounds of water for every pound of growth the plant makes (not counting the water in the plant). Thus, to make a single cornstalk which, with its ear, weighs 4 pounds when perfectly dry, the roots of the stalk must take up about a ton of water from the soil. We shall learn later what becomes of this enormous quantity of water. We are here concerned with where it comes from. It is easily seen that the soil must be in good condition for 
the capillary movement of water through it in order to deliver this amount of water to the growing crop.

Plant roots need air just as badly as they do water. though they do not require such large quantities of it. Air also does other important things in the soil. Without it the vegetable and animal matter in the soil cannot rot rapidly and thus set free the stores of plantfood material it contains.

The usual method of loosening up the soil is by plowing. Types of plows in common use have already been mentioned (Chapter Three). Plowing also kills weeds, and turns under humus-making material if any is present. Figure 28 shows good work with the plow.

Depth of plowing. No set rules can be laid down to govern depth of plowing. If the soil is well supplied with decaying vegetable matter, and has no weeds on it or weed seed in it, excellent crops can be grown without plowing at all. Sandy soils, being more open than heavier soils, are less in need of plowing, unless infested with weeds, or unless they are in need of more vegetable matter. But a loam soil, or any type heavier than a loam, especially if it has little vegetable matter in it, is greatly benefited by the loosening up and resettling that comes from a good plowing, followed by the usual operations of disking, harrowing, etc., used in preparing a seed bed. On weed-infested land plowing is a necessary part of seed-bed preparation.

The more a soil is in need of plowing, except where the plowing is done merely to kill weeds, the deeper the plowing should be. But it is not wise to plow a poor, hard soil deep when for many years it has been plowed 
shallow. Deep plowing in such a soil would throw up a lot of subsoil that has little or no humus in it, and little, tender plants cannot grow well in such a soil. It is far better in such cases to plow about an inch deeper each time, until within a few years a depth of about $\delta$ or Io inches is reached. This allows time for the freshly thrown-up subsoil to get some humus in it, and to become mellow through the action of air and moisture.

Good farmers, who keep their land well supplied with humus, plow at depths ranging from 5 to ro inches, plowing a little deeper when the work is done in the fall than when it is done in the spring. It is always a good plan to follow the practice of those farmers in the community who have the best crops, unless it is known that there is a better way.

Subsoiling. Subsoiling is the practice of loosening up the soil below the usual depth of plowing, but without turning the subsoil up to the surface. Special subsoil plows are sometimes used for this purpose. They are very heavy to pull, and this makes their use expensive. The only part of the country where subsoiling has become at all common is in those localities of the South Atlantic coast where the system of farming is such that the vegetable matter has almost completely rotted out of the soil and nothing is done to restore it. The usual practice in these localities is to run a small plow in the bottom of the furrow made by an ordinary turning plow. This loosens the subsoil, but does not throw it out on top. Where the soil is properly supplied with vegetable matter, subsoiling is seldom practiced. From this we may conclude that 
farmers who keep their land in good condition have not found subsoiling profitable.

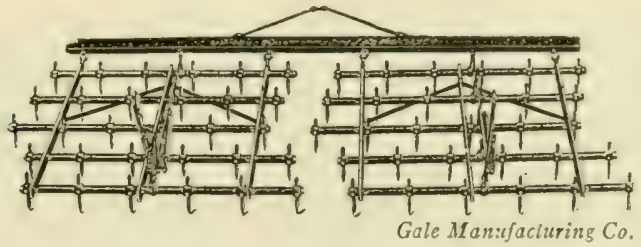

FIG. 29. A drag harrow, or spike-tooth harrow.

Second object of tillage. The second object of tillage is threefold: (I) to pack down the lower portion of the plowed layer so that there will be no large airholes in it. Plant roots cannot grow into these large open spaces, for there is no moisture or plant food there for them. (2) To break the surface soil into fine particles. (3) To level the surface of the land.

Various implements are used in accomplishing these three purposes. Perhaps the commonest of these is the drag harrow (Fig. 29). Many farmers use nothing but this implement in preparing a seed bed after

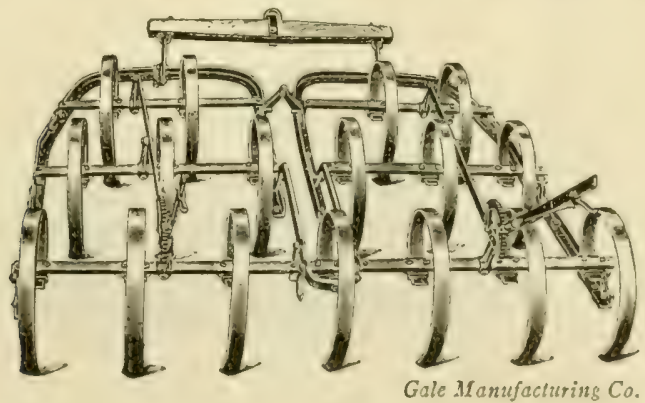

FIG. 30. A spring-tooth harrow; much used on stony ground. 


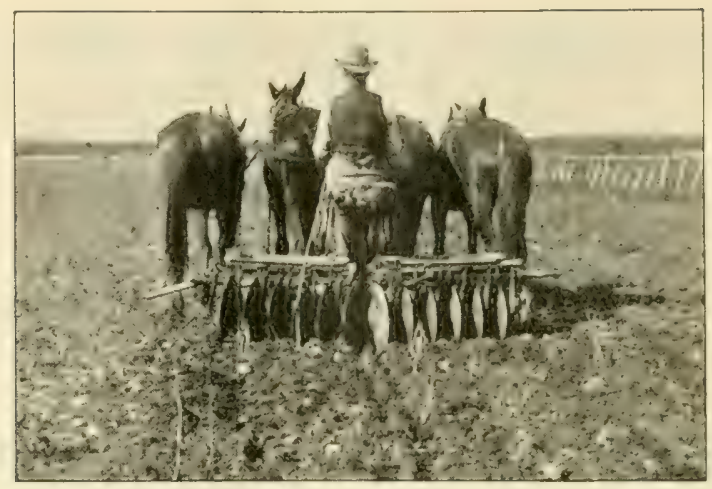

FIg. 31. A disk harrow.

the land has been plowed. There are numerous forms of the drag harrow used in different parts of the country, but they all act on the same principle as the one shown in the figure.

On land that is stony, or which has recently been cleared of timber and still contains tree roots that interfere with tillage, the spring-tooth harrow is frequently used. This implement is shown in Figure 30.

In preparing fall-plowed land for a spring crop, the disk harrow is much used (Fig. 3I). This implement

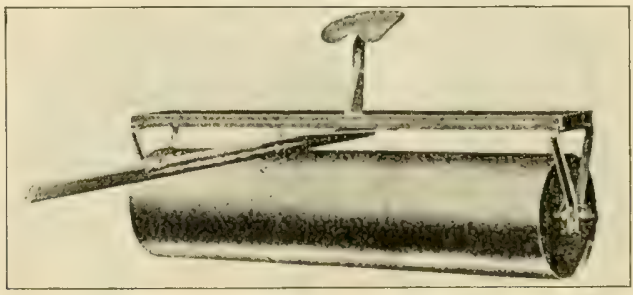

B. F. Avery \& Sons

Fic. 32. A roller. It firms the soil, crushes clods, and makes the surface of the soil smooth. 
is also excellent for pulverizing a tough sod after it has been plowed. It is used, too, where it is desirable to pulverize the surface soil to a considerable depth, for it can be made to work deeper than the drag or springtooth. Some farmers use the disk harrow instead of the plow, going over the land several times with it.

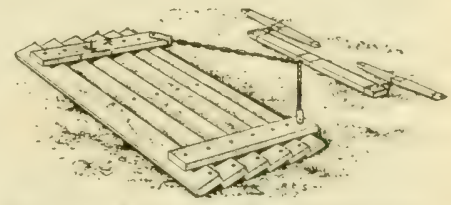

FIG. 33. A plank drag, or clod masher; a home-made implement.

The roller (Fig. 32) is used by many farmers, though there are numerous farms on which this implement is not found. It packs the soil down so as to close all large open spaces in it, and leaves the surface quite smooth. It also crushes a good many clods, and thus aids considerably in making a good seed bed.

The plank drag, or clod masher, usually a homemade implement (Fig. 33), is an excellent thing for breaking up clods. In regions of heavy clay soil this implement is frequently found on farms.

Numerous other implements are used here and there over the country for the purposes above mentioned. It would take too much space in a book of this size to discuss all of them. Those mentioned are by far the most common implements for fitting plowed land for seeding.

Tillage before plowing. The objects mentioned under the previous heading may be partly accomplished before the land is plowed, and in some instances this is excellent practice. Thus, on the wheat land of eastern Washington, eastern Oregon, and northern Idaho, the best farmers often disk wheat stubble in the fall, and again 
in the spring before they begin plowing for summerfallow. This loosens the surface soil so that when the lind is plowed no large air spaces are left in it. More important, however, is the fact that this mulch of loose earth prevents the land from drying out before the plowing can be finished. In this region there is little or no rain in summer, and late spring plowing leaves the land very cloddy unless this preliminary disking is done. Where this practice is followed, the land raises a crop only every other year.

Figure 34 shows how disking before plowing affects the soil. The first section of the figure (at the top) shows the result of plowing grass land with no preliminary preparation. In the second section the land has been disked before plowing. The third section shows the effect of disking after plowing. The last shows the effect of disking both before and after plowing, giving a seed bed with no large air spaces in it, and with all the soil well pulverized.

What is a good seed bed. A good seed bed means a soil that has been loosened up to let the air in, thoroughly pulverized, packed down again sufficiently to remove all large air spaces, and made fine and soft at the surface. It is level, and free from trash that would be troublesome in later tillage operations. It also contains plenty of plant food, a matter about which we shall learn more later.

Third object of tillage. The third, and perhaps most important, object of tillage is the destruction of weeds. If a soil is in good condition, and has no weeds or weed seed in it, very good crops can be grown without tillage 

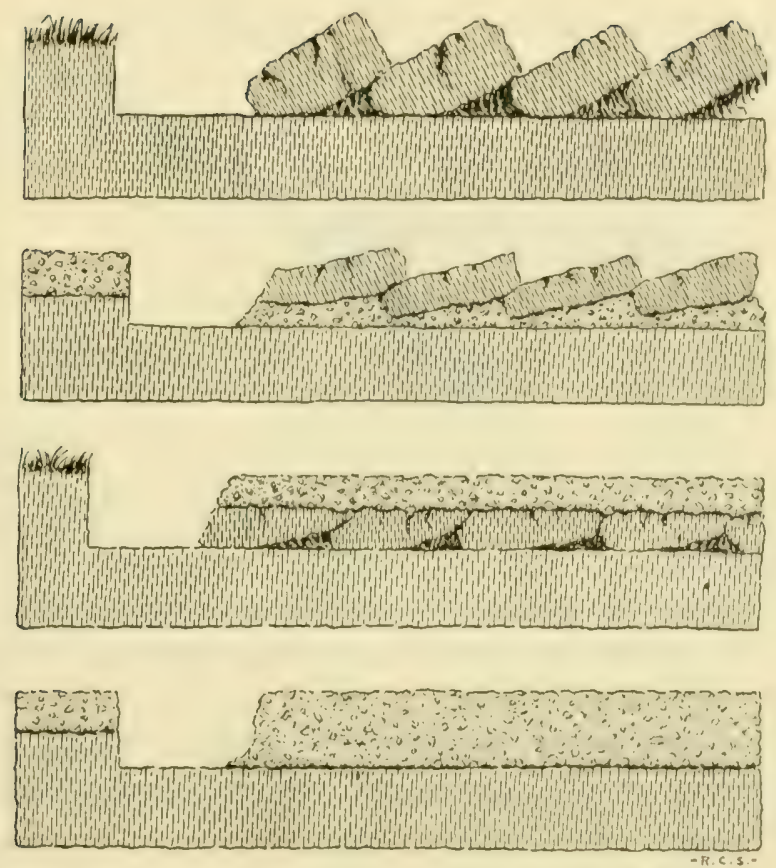

Modified from "Soil Cullure" by IV. E. Taylor

Fic. 3. One way of preparing at goosl seed bed. Top section: land plowed with no preliminary preparation. Secomel acetion: lamd disked before plowing. Note absence of large air spaces. Third section: land disked after plowing, but not before. Fourth section: lamed disked besh before and after folowing. A good seed bed clear to the bottom.

of any kind. But every weed that gets to be an inch high in a growing crop) reduces the yield of that crop). It is a proverb in regions where rainfall is none $t(0)$ plentiful that you can't grow two crops at once, meaning that you cannot secure a good yield of any crop that is badly infested with weeds. The lazy farmer who waits till all the weeds in his cornfield are sprouted, 
so that he can kill them all at once, has to buy feed for his horses.

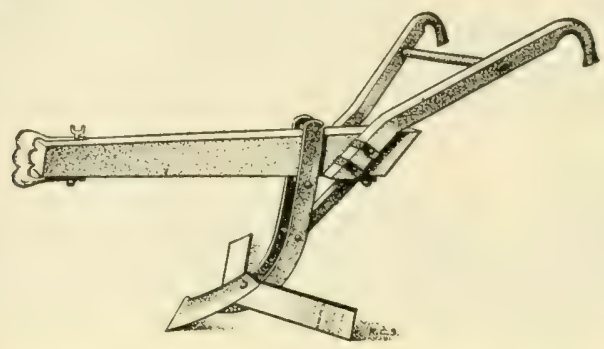

FIG. 35. A sweep; a one-horse cultivator much used in the cotton states.

Plowing and the subsequent tillage operations, such as harrowing, disking, etc., destroy many weeds. They also tend to cause weed seed in the top few inches of the soil to germinate, which gives a chance to kill them before the crop is planted. If the surface soil is thus made clean before planting time, thickly planted crops like wheat or oats are usually able to keep ahead of weeds that come up later from deeper in the soil, so that they do not become weedy. But if the weed seed in the surface soil are not destroyed, such crops may suffer from weeds.

Crops like corn, cotton, and potatoes, that are planted in rows several feet apart, leave so much of the ground bare that weeds soon take possession unless something is done to prevent them from doing so. Hence we cultivate crops of this kind. The more common forms of cultivating implements are briefly discussed in the following paragraphs.

In the cotton-growing states a great variety of cultivating implements are used, most of them being designed 
for one horse. Perhaps the commonest form of cultivator used in that section is the sweep (Fig. 35). This implement goes under several different names in different localities, such as heel sweep, scrape, heel scrape, etc. It is sometimes called a "buzzard wing," though this name is usually applied to quite a different form of implement. The narrow shovel in front is called a "scooter," the flat bars extending to the side constituting the sweep. The object of the scooter is to hold the implement in the ground, while the sweep scrapes along just under the surface and cuts off the weeds and grass.

Figure 36 is the old-fashioned "double shovel," formerly widely used in the corn belt states, but now generally discarded in favor of some of the implements to be mentioned later, and which permit the use of more horses per man. The double shovel is still used to some extent in the region where the cotton belt and the corn belt meet. The objections to it are that it utilizes the power of only one horse, which is also true of the sweep, and it stirs the land too deeply, thus de-

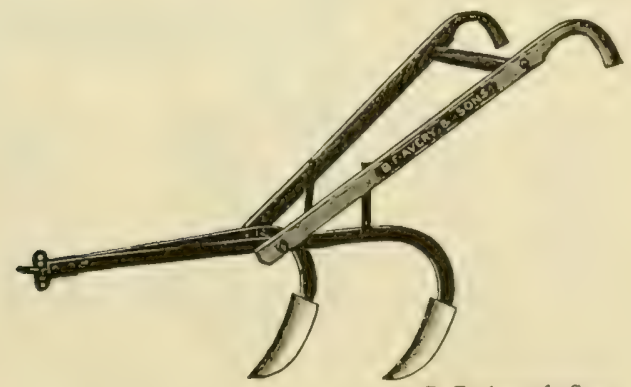

B. F. Avery \&o Sons

Fic. 36. A double shovel; another one-horse cultivator. 


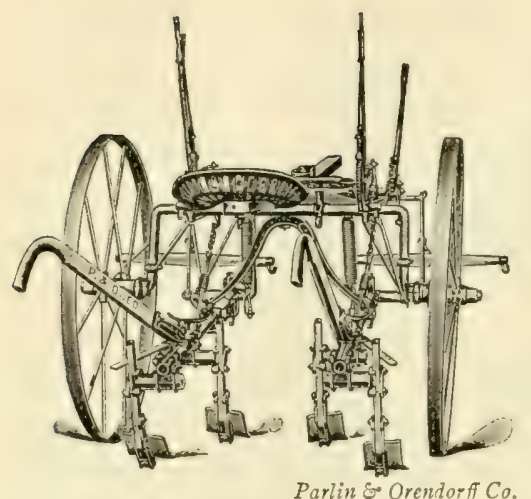

Frg. 37. A four-shovel one-row cultivator, very common in the corn-growing states; a two-horse implement. stroying many of the roots of the growing crop. (See Figure 4I.)

Figure 37 shows what is known as a one-row, four-shovel cultivator. This and the next cultivator (Fig. 38) are made in both walking and riding patterns. It is a two-horse implement, and is probably the most generally used of all cultivators in the great corngrowing states. This cultivator also stirs the soil too deeply. It kills many corn roots.

Figure 38 shows a better form of the one-row cultivator. It has three small shovels on each side of the row. These stir the surface soil but do not penetrate as deeply as the larger shovels seen in Figure 37. Similar.

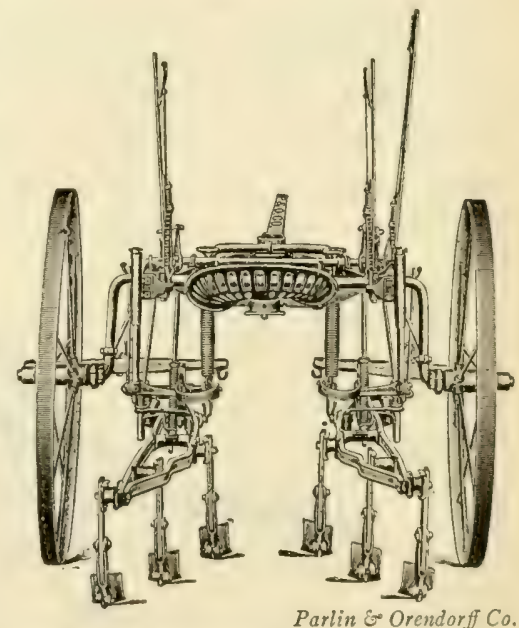

FIG. 38. A six-shovel one-row cultivator; a two-horse implement. 
cultivators are made with four smaller shorels on each side.

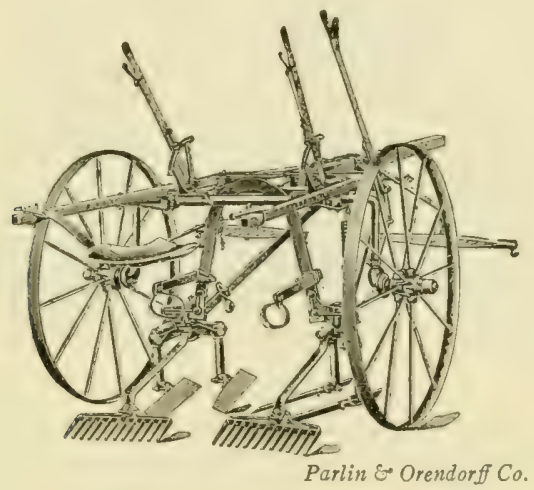

FIG. 39. A "surface" cultivator; for two horses.

Another form of one-row, two-horse cultivator is seen in Figure 39. Instead of shorels it has wide, thin blades that merely shave off the top inch or so of the soil. The farmers call this a "surface" cultivator. It is coming into use in the central part of the corn belt, mainly in Illinois and Iowa. This implement is not used where the land is stony. The principle on which it acts is similar to that of the sweep, mentioned above.

Figure 40 shows an implement that cultivates both sides of two corn rows at a time. It requires three horses. It is much used on large farms in the corn belt states. One man, on good prairie soil, can cultivate So acres of corn a year with this implement. It is somewhat difficult to use when the corn is small. for the driver can watch only one row at a time. Hills of very young corn are liable to be covered up by dirt in the row 
the driver is not watching. After the corn is large enough not to be covered in this manner, this cultivator works very satisfactorily. It is especially desirable when farm labor is scarce, because it enables one man to cultivate as much corn as two would cultivate with a one-row implement.

There are numerous types of special cultivators for potatoes, sugar beets, orchards, garden crops, etc. Lack of space prevents their consideration here.

Figure 4I shows why deep cultivation is not advisable after the crop is well started. It shows two hills of corn planted the usual distance apart. The stalks are not half grown, yet their roots meet in the middle between the rows. Deep cultivation would kill many of these roots, and this would injure the growing crop. When the crop is very young, it is permissible to cultivate deeply in the middles, but even at that time cultivation near the row should be shallow, for the soil near the hills is full of young roots.

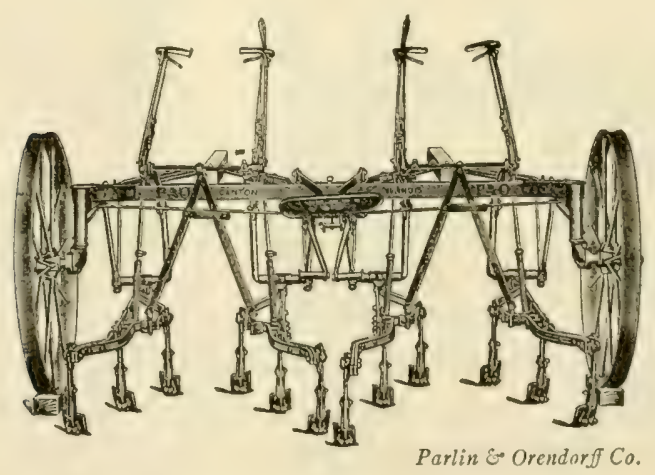

Fig. 40. A two-row cultivator; for three horses. 


\section{Tillage}

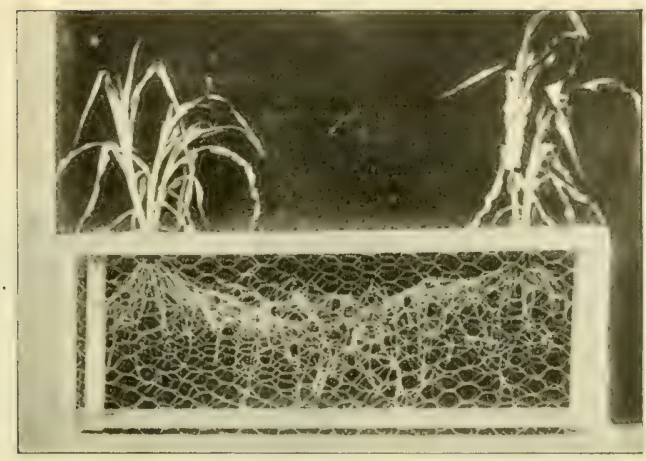

Corn Investigations, $U . S . D . A$.

FIG. 4I. Corn roots in soil between the rows. Corn less than half grown. Deep cultivation would destroy many of these roots and injure the crop. Grown in wire netting to keep roots in position when the soil is washed away.

\section{Experiment}

Fill three tin cans three fourths full of some heary kind of soil-clay, if it is available. This experiment will not work with sandy soil. Add water to each of the samples till they are quite moist and soft. Label the cans $A, B$, and $C$. Cover the soil in can 1 with sand, filling the can to the top with it. With a stick, stir the soil in can $B$ thoroughly, and then pack it down tight. Leave can $C$ as it is, and set all three samples away till $B$ and $C$ are dry. This may take several days. At the end of this time, examine the three samples carefully and note the differences between them. Can you explain these differences? Does this experiment throw any light on the advice given in the text about not plowing heary soils when they are wet? What effect did the mulch of sand have? Why is clay soil worked like dough when bricks are to be made of it? What does the working do? 


\section{CHAPTER SIX}

\section{TERRACING, DRAINAGE, IRRIGATION, AND DRY FARMING}

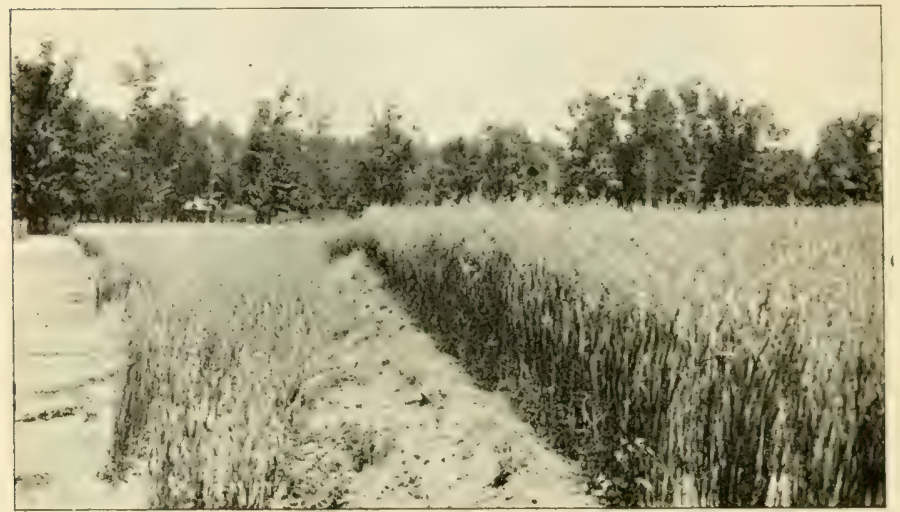

FIG. 42. A terrace so constructed that water flows over it in a thin sheet. This prevents washing.

\section{TERRACING}

Definition of terrace. Strictly speaking, a terrace is a level or nearly level strip of land running across the face of a hill. Figure 42 will give some idea of what this means. It shows a well-constructed terrace in a field at the Georgia Experiment Station. When there is a series of such terraces, one above another, such as is seen in Figure 43, a complete terrace includes both a level strip and the steep slope that separates it from the next one below. In the South Atlantic states, where terraces are common, farmers apply the term "terrace" indifferently to either the level strip of land or the ridge or steep slope between two such strips. Terraces are often merely ridges thrown up to break the force of water 
flowing down the face of a hill, especially where the slope is not very great. Terraces of this kind are shown in Figure 44. These ridges slope gently so as to lead the water to one side of the field.

In some parts of the world very elaborate series of terraces have been constructed on mountain sides in order that crops may be grown on them. The famous "hanging gardens" of ancient Babylon were simply terraces of this nature. Long before Columbus discovered America, the Indians of Peru had built such terraces. Similar ones are found today on steep mountain sides in certain parts of the Philippine Islands.

Where terraces are found in this country. In the United States much of the farm land is terraced in the Carolinas, Georgia, Alabama, and parts of southern Virginia. There are three reasons for this. Nuch of the farm land is hilly, the rainfall is heavy, and the system of farming is one that does not keep the soil well supplied with vegetable matter. All these circumstances cause the soil to wash, and terraces are designed to prevent

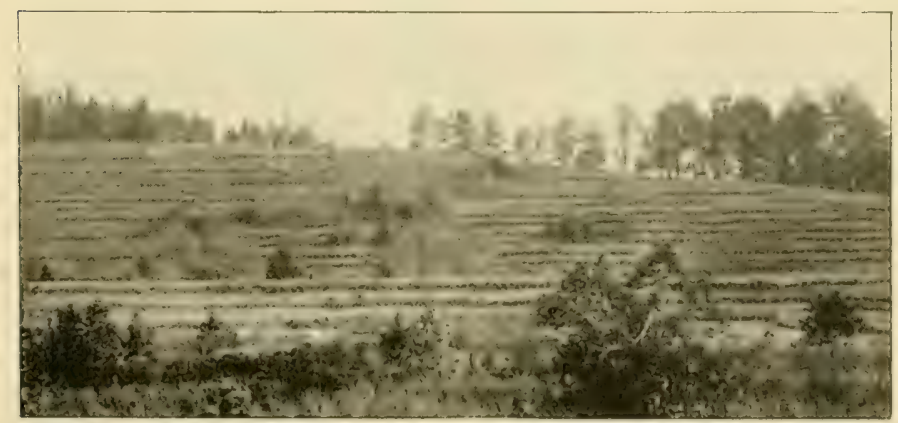

Fig. 43. A series of terraces on a hillside in one oi the Suth Atlantic states. 


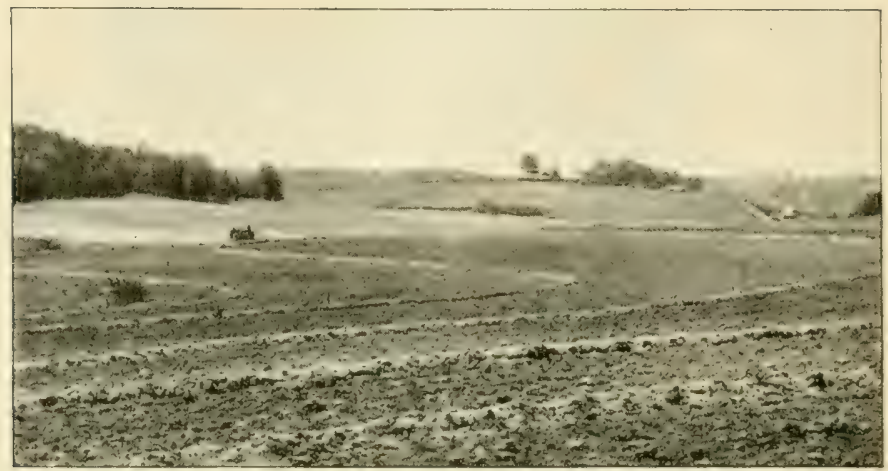

Fig. 44. Ridges designed to cause water to flow slowly to the side of the field, and thus prevent washing. A common, but undesirable, form of terrace in the South Atlantic states.

this washing. In some localities in this region the farmers are so accustomed to terracing their land that they sometimes run ridges across fields that are practically level.

Disadvantages of terraces. While terraces are necessary under the conditions described above, they are a decided nuisance on the farm. In the first place, it requires a great deal of labor to keep the terraces in order, so that they will actually control the flow of surface runoff during heavy rains and thus prevent the soil from washing. In the second place, the ridges or slopes occupy land, and thus reduce the crop area. Unless well tended, they harbor weeds, which scatter their seeds over the cultivated land. Lastly, it takes much more time to cultivate a terraced field than a field of the same area without terraces.

The Mangum terrace (Fig. 45), named from the farmer who invented it, avoids this last difficulty. The ridges 


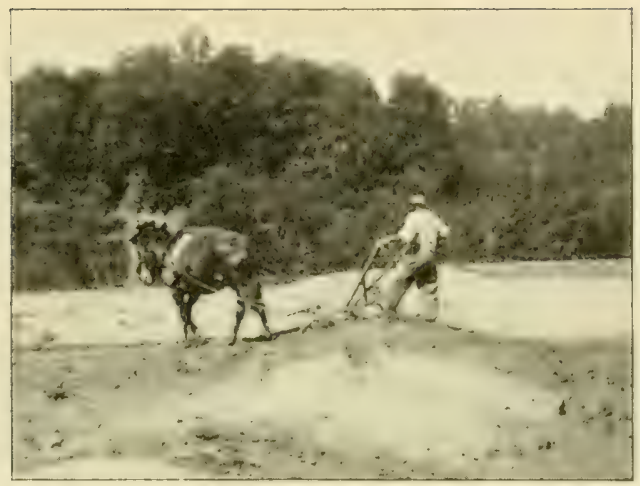

Fig. 45. The Mangum form of terrace, which does not interfere with tillage.

do not run across the slope on an exact level, but slope gently one way, so that the water which collects behind them flows slowly to one side of the field. In this way the flowing water is prevented from cutting into the soil. A pamphlet describing the Mangum terrace may be obtained from the United States Department of Agriculture.

\section{DRAINAGE}

Where drainage is needed. Wherever the soil is wet enough to interfere with tillage operations, or where there is so much water in the soil that plant roots cannot get plenty of air, some kind of drainage is necessary for best results with ordinary farm crops.

Effect of drainage on alkali. We have already learned that alkali is merely the soluble mineral matter set free in the soil by the disintegration of the soil particles. and then collected at the surface, where the soil moisture evaporates. When a good system of drainage has been 
established, the irrigation water turned on to the field dissolves the alkali and, if enough water is used, carries it away through the drains. A field ruined by alkali may thus in time be made to produce good crops again. But this method of reclaiming alkali land is expensive.

Why drained soils are usually rich. Most soils that need drainage are valley soils, having in them a great deal of vegetable matter that has been washed down from surrounding uplands. This tends to make them rich. Again, there is usually an abundance of moisture just below the level of the drains, and this moisture can rise by capillary action up to the plant roots above the drains. This insures the crop pleniy of water. Drainage is an expensive operation, but the soils that need it are usually so rich that it pays well to drain them.

Kinds of drains. While many kinds of drains are used, only two of them are common. These are open ditches and tile drains. Open ditches are much used in localities where the rainfall is so heary that ordinary sizes of tile will not carry away the surplus water during hard rainstorms. They are often used as makeshifts elsewhere, but wherever tile drains will operate properly they are decidedly the best form of drainage. Good tile drains, when properly laid, are permanent. Although they are expensive at the start, it costs very little to keep them in proper repair, while open ditches require continual care and take much time for their maintenance.

How tile are made. Tile are made from the same material and in the same manner as brick. They are made in the form of tubes, usually about a foot long, and 4 or more inches in diameter (inside). Some are as 


\section{Drainage}

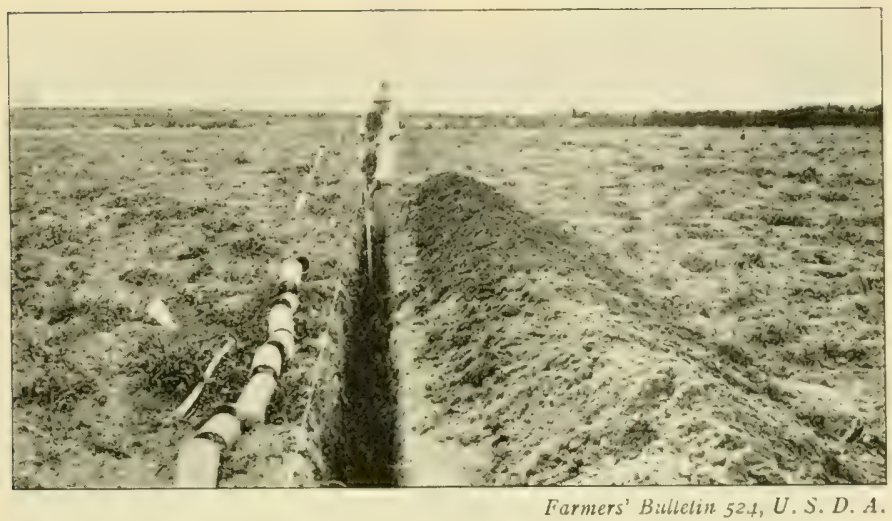

FIG. 46. Digging a ditch preparatory to laying tile.

small as 3 inches, but it is not desirable to use such small sizes. They get out of line too easily, and are too likely to become clogged by dirt.

How tile drains are made. First, a narrow ditch is dug where the drain is wanted (Fig. 46). In order to keep the tile in line, the bottom of the ditch is shaped to fit the tile; it is made round by a special implement. Figure 47 shows this implement, along with other tools used in digging ditches and laying tile. When the ditch is ready, the tile are laid in it, end to end, as close together as may be (Fig. +8). The ditch is then filled with dirt. Being rough, like bricks, the ends of the tile do not fit together snugly. This gives a chance for the water in the surrounding soil to seep into the tile at the joint where two tile ends come together.

As soon as the work of laying the tile is finishei, an accurate map of the lines of tile should be made. Unless this is done, it will require a lot of time and labor to find 
the lines again should one of them become clogged and need cleaning out.

Proper depth of tile drains. Tile should be laid deep enough to give plenty of room for the development of plant roots above them, for there will usually be water below the level of the tile, and the roots of our ordinary farm crops cannot grow in water. In any except a sticky clay soil, or other very heavy soil, $3 \frac{1}{2}$ or 4 feet is about the proper depth. In heavy; fine-grained soils, water does not flow readily, and tile should be laid shallower. But in the most extreme case the drains must be laid deep enough not to interfere with tillage operations. It is hardly worth while to drain land less than 2 feet deep, for plant roots would not have sufficient room to develop with the water table closer to the surface than this.

Distance apart of lines of tile. The width of the strip of land a single line of tile will drain depends on the

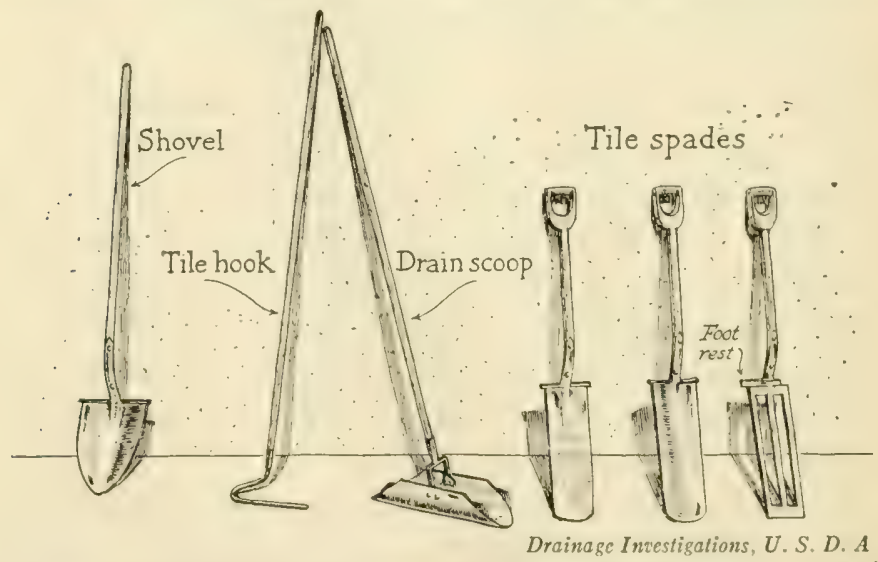

FIG. 47. Tools used in ditch digging and tile laying. The drain scoop is used in shaping the bottom of the ditch to fit the tile snugly. 


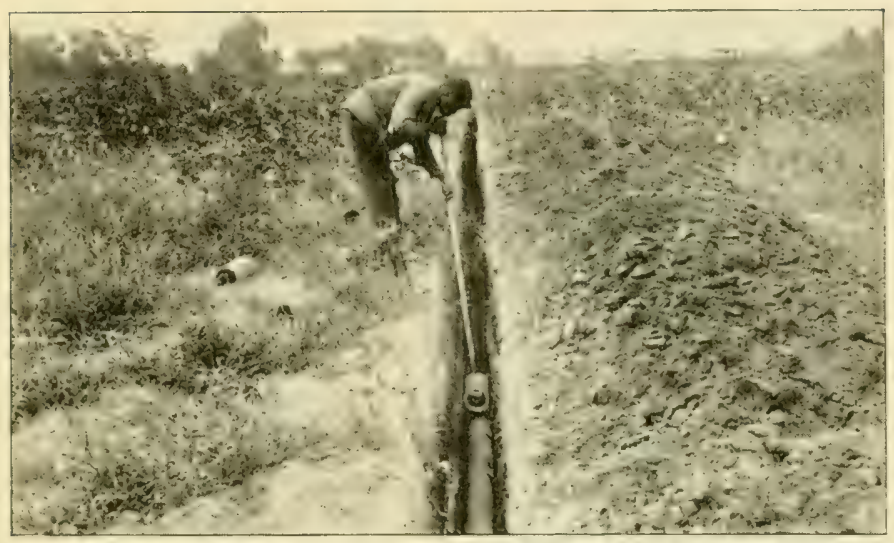

Farmers' Bulletin 524, U. S. D. A.

FIG. 48. Placing tile in position with the tile hook. (See Figure 47.)

depth at which the tile is laid, and on the texture of the soil. The deeper the drain and the more sandy the soil, the farther apart may be the lines of tile. In a sandy soil where it is possible to put the drains 4 feet deep, a single line of tile will usually drain a strip 80 feet wide, or even wider. In a heavy clay soil, where it is not practicable to bury the tile more than $2 \frac{1}{2}$ feet deep, it is usually necessary to lay the lines of tile not more than 20 or 25 feet apart.

Slope of lines of tile. It is necessary that the lines of tile run down hill in order that the water may flow in them. The smaller the tile, the greater the slope required. A few inches per hundred feet of tile will usually be sufficient to insure ample drainage.

It is a matter of great importance to see that there is always a downward slope inside the tile. Otherwise dirt will collect in it at the low places, and thus render the tile ineffective. 


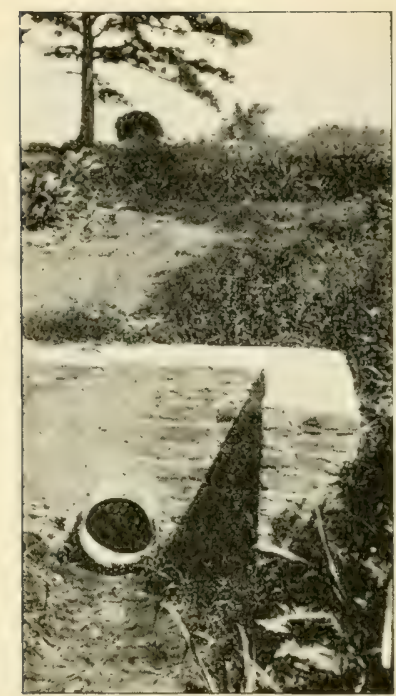

Drainage Investigations, U.S. D.A.

Fig. 49. A well-constructed drain outlet on a South Carolina farm. It needs wire netting, or other device, over the mouth of the drain to keep out small animals which might enter and obstruct the system.

Why the outlet of the drainage system must be protected. If the system of tile drains ends in an open ditch, the dirt is liable to fall in and cover it up. This will stop the flow of water and cause the water to back up in the tile. Figure 49 shows how to prevent this. The brick wall surrounding the outlet of the system keeps it free from obstruction at the mouth.

The outlet shown in Figure 49 is not yet finished. If the end of the tile were left open as it was when this picture was taken, it would become a harboring place for frogs, turtles, rabbits, etc. When these small animals enter a system of tiles, they are unable to find their way out again. Their bodies then obstruct the system and render it useless. To aroid this, the open end of the tile should be covered with wire netting, a drop board, or some other suitable device.

\section{IRRIGATION .}

Irrigation regions. In the southern portion of the United States farm land is usually irrigated where the rainfall is less than about 30 inches a year. In the 
North, irrigation is seldom practiced where the rainfal! is more than 15 or 20 inches. There are two reasons for this difference. In the first place, rainfall in the South is more bunched than it is in the North. Nore of it falls at a single rain, and hence more is lost by surface run-off. In the second place, more soil moisture is lost by evaporation in the South than in the North, because of the higher temperatures in the South. Certain crops are grown in the North with as little as ro inches of rainfall. See the next section of this chapter for an account of this so-called " dry farming."

It is only in the western portions of the country that the rainfall is so light as to make irrigation actually necessary, though here and there in all the eastern states may be found farmers who irrigate crops of vegetables in dry weather. Figure 50 shows the irrigation of a field of onions in Georgia, where the average rainfall is heary.

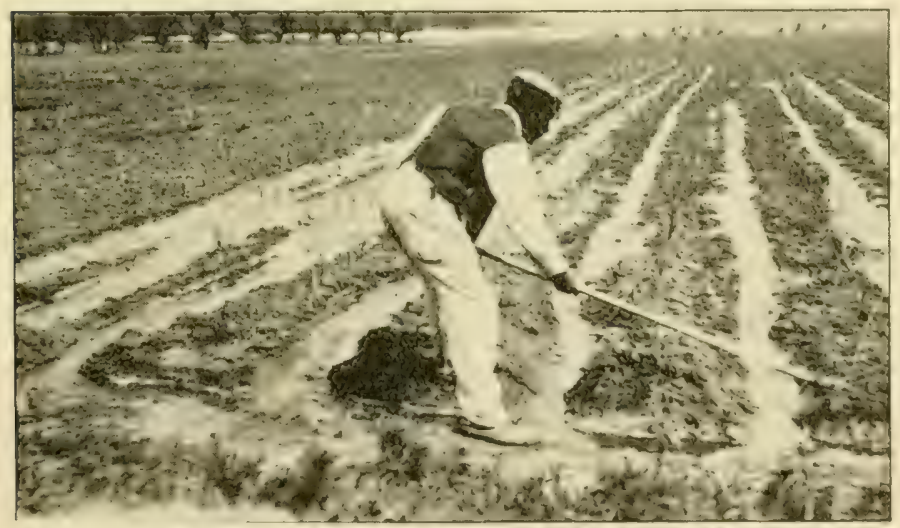

Irrigation Imesizgalions, U. S. D. A.

FIG 50. Irrigating a truck crop in Georgia, where the rainfall is heavy. This insures good crops in spite of periods of dry weather. 
Irrigation is practiced to a greater or less extent in the western portion of all the line of states from North Dakota to Texas, and in all the states to the west of these, though some crops are grown without irrigation in all these states. In much of eastern Washington, eastern Oregon, and northern Idaho the land is not irrigated, while in western Washington and the northern portion of western Oregon there is abundant rainfall - even too much in some places near the coast.

Advantages of irrigation. The farmer who has plenty of irrigation water can water his crops when they need it. This enables him to grow large crops. In the West one often hears the remark that rain is a very poor substitute for irrigation. Since irrigated crops yield better than those not irrigated, it requires less land for a good farm in irrigated regions than it does in regions that depend on rainfall.

Disadvantages of irrigation. The streams that furnish irrigation water do not always run full. When they fail, the crops suffer just as they do in times of drought elsewhere. Sometimes too many farmers try to get water from the same stream, and all of them suffer in consequence. It costs a great deal to build the necessary irrigation ditches and to keep them in repair. In some cases the cost is so high that the farmers are compelled to engage in the most intensive kinds of farming, such as fruit growing and truck farming, in order to pay for the irrigation water and make interest on the investment. Unfortunately, most of these lands are a long distance from the great cities where there are extensive markets for such products. Crops of this kind occupy only 
about 4 per cent of our total crop area. It is easy to produce so much of them that no market can be found. This brings disaster to small farmers who have nothing else to sell and who are at a long distance from market.

Nearly every irrigated district has sooner or later to deal with the problem of alkali. When water is turned on to lands that have never been water-soaked before, it finds in the soil great quantities of soluble mineral matter. This it promptly dissolves, and then, evalporating at the surface, it leaves the soluble minerals there in such quantity that growing crops are poisoned by them. We have already seen that the remedy for this is tile drainage, which is expensive. Farmers will usually not go to this expense until alkali has begun to ruin their crops, when they frequently do not have the money for it.

The waste water which careless farmers allow to form pools by the roadside and elsewhere in irrigated regions makes breeding places for mosquitoes, and these little pests spread malaria if they happen to get it.

Despite all these disadvantages and difficulties, irrigation farming has proved highly profitable in localities where real-estate promotion schemes or the cost of installing the ditches have not made the land too high priced.

A common fault of irrigators. Where irrigation water is at all plentiful, many farmers use entirely too much of it. This hastens the coming of alkali. Where the water is none too plentiful, it robs other farmers of their rightful supply. Where the farmers themselves do not 


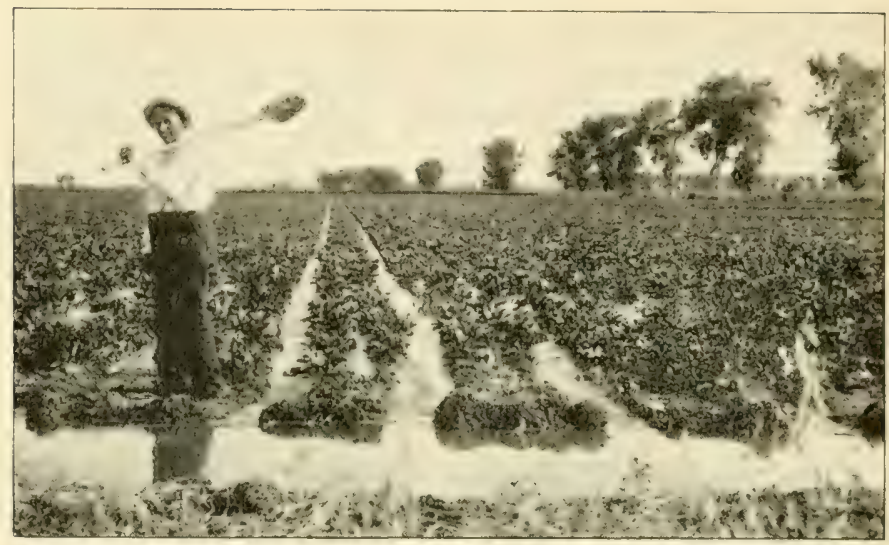

Office of Farm Management (L. A. Moorhouse)

FIG. 51. Irrigating sugar beets in one of the Mountain states. The water is run in furrows between the rows.

own the large ditches that bring the water to their farms, there is nearly always trouble between them and the ditch owners over this question of the proper amount of water to use.

Methods of putting water on the land. Each locality has to some extent developed its own methods of putting water on the land. Much depends on the soil. Sandy soils cannot be handled like clay soils. The crop growing on the field makes a difference. A method useful in an orchard might not do well in a field of alfalfa.

The most common method of irrigating is to conduct the water over the field in small furrows from a foot and a half to several feet apart. For crops grown in rows, such as potatoes and sugar beets, the water is run in furrows between the rows (Fig. 5I). In orchards it is 
sometimes run in furrows that follow the tree rows, making a half circle around each tree. More commonly it is run in furrows between the tree rows, as shown in Figure 52 .

When the water is allowed to flow over the land or to run in furrows, great care must be taken not to let it run fast enough to cut the soil away. The rate of flow in a furrow is governed by the slope of the land and the amount of water allowed to flow. The best method to use in any given case depends on the character of the soil and the nature of the crop to be grown. In this, as in other matters of farm practice, the beginner should use the methods of his most successful neighbors whose conditions are similar to his, unless he is sure he knows a better way.

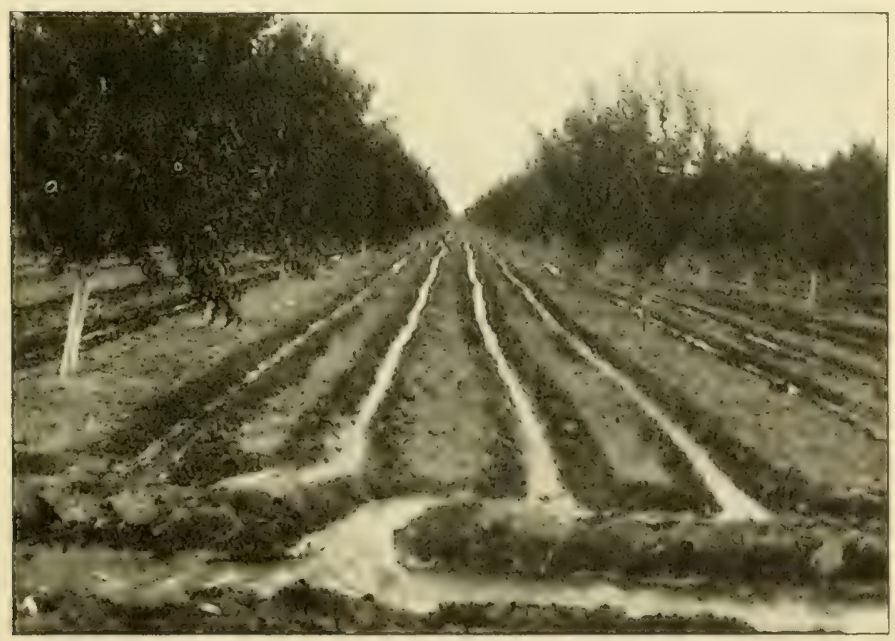

U. S. Reclamation Serrice

FIG. 52. Orchard irrigation on the Pacific Coast. 


\section{DRY FARMING}

What is "dry" farming? Since good farm land began to be scarce in this country, many farmers have settled in localities where the rainfall is so light that it is difficult to grow good crops and where irrigation water is not to be had. Under these conditions it is necessary to use the best possible means of preventing loss of the small rainfall. The methods used by these farmers for saving soil moisture are known as dry farming methods.

How water is lost. When a heary rain occurs, much of the water runs off into streams without ever soaking into the soil. Even when moisture gets into the soil, much of it may rise again to the surface by capillary action and there evaporate. The amount thus lost may be very large. In regions of heavy rainfall much of the rain that falls sinks deep into the ground and later appears in springs, but not much is lost in this way in dry countries.

How to prevent these losses. To prevent rain water from running off the land into streams, the soil must be in condition to soak up the water as fast as it falls. The principal method used by dry farmers to bring this about is to plow deep -8 , Io, or even $\mathrm{I} 2$ inches.

If the soil could be kept well filled with vegetable matter, rain would readily soak into it. But the dry farmer dare not use this method extensively, for it is liable to make the soil so loose that it will dry out completely when dry weather comes.

One very successful dry farmer has adopted the method of terracing his land to prevent run-ofi of rain water. 
His large farm is covered with a system of ridges thrown up with a plow. These ridges run on the level, and when a hard rain comes, the water is held back by the ridges until it has time to sink into the soil. The system of terracing used on this farm is essentially like that shown in Figure 44 (page 76 ).

To prevent loss of moisture by evaporation, the most important thing is to prevent absolutely all weed growth. Weeds do not cause surface evaporation, but they suck up enormous quantities of water through their roots, and then evaporate it at their leaves.

Summer-fallowing. In dry-farming regions many farmers summer-fallow a portion of their land every year. That is, they plow it up in the spring and leave it bare during the summer, using the utmost care to prevent any weed growth. If weeds start, some kind of cultivator is run over the land. In the fall or the next spring, a crop, usually wheat, is sown on this fallow land. This method gives the crop practically two years' rainfall, though it takes two years' use of the land to produce a crop. Summer-fallowing is by far the surest way of getting a crop in very dry regions, and if the land is not too high priced, there is no particular objection to it. But high-priced land must produce a crop every year in order to pay interest on the investment.

West of the Rocky Mountains, where nearly all the rain comes in the winter, the best method of summerfallowing is to go over the land in the fall, and again in the early spring, with a disk harrow (Fig. 3I, page 64); then plow it as soon as possible, and keep the weeds off during the summer. The two diskings produce a dirt 
mulch that serves to keep the land from baking when dry weather comes in early summer before the plowing is finished.

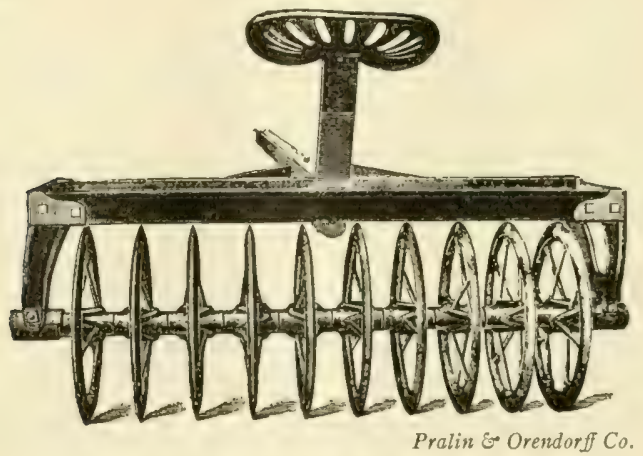

Fig. 53. A subsurface packer.

Subsurface packer and its use. Two implements sometimes found on farms in the dry-farming country are shown in Figures 53 and 54. These two implements serve the same purpose. When either of them is run over freshly plowed land, it sinks into the soft dirt, pressing it down so as to remove all large air spaces in the lower part of the plowed layer, but leaving the surface loose, thus making a very good seed bed.

Uncertainty of harvests in dry countries. While the practice of the methods above outined will enable the farmer to grow crops in many years when ordinary methods would fail, it must be remembered that in all dry countries there are seasons when the rainfall is so light that it is impossible to grow good crops. Where the arerage rainfall is $I_{5}$ inches, it is less than this at least half the time, and sometimes much less. The wise 
farmer in a dry country therefore keeps a supply of feed ahead for a dry year.

Drought-resisting crops. Some crops will stand much more dry weather than others. The most successful dry farmers have learned this and devote their land largely to such crops. The most prominent group of plants of this character is the sorghums. The common sorghum cane which is grown in the Central states for sirup making is much grown for hay in the Plains region. When grown for hay, it is sown very thick so that it will not grow too rank. Soudan grass, a relative of sorghum, is also coming into very general use as a hay plant in the dry-farming country. Kafir, milo, and feterita are other members of the sorghum family extensively grown for grain in dry regions. These three crops resemble each other closely. Figure 55, on the next page, shows a field of kafir in western Oklahoma.

Among the common grain crops, rye is the most able to resist drought. It is increasing in popularity in the dry-farming country. Wheat, although not especially resistant to drought, is very widely grown on dry lands, but much of it is grown on summer-fallowed land, and thus gets the benefit of more than one year's rainfall. The durum wheats are drought resistant, and are much

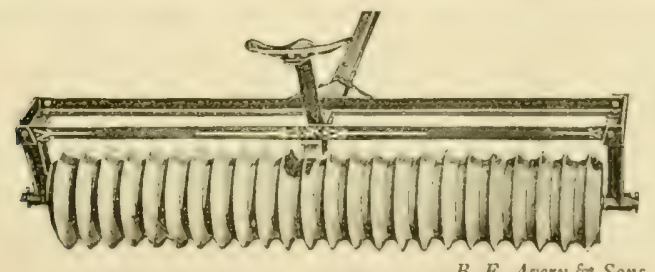

FIG. 54. A corrugated roller. 


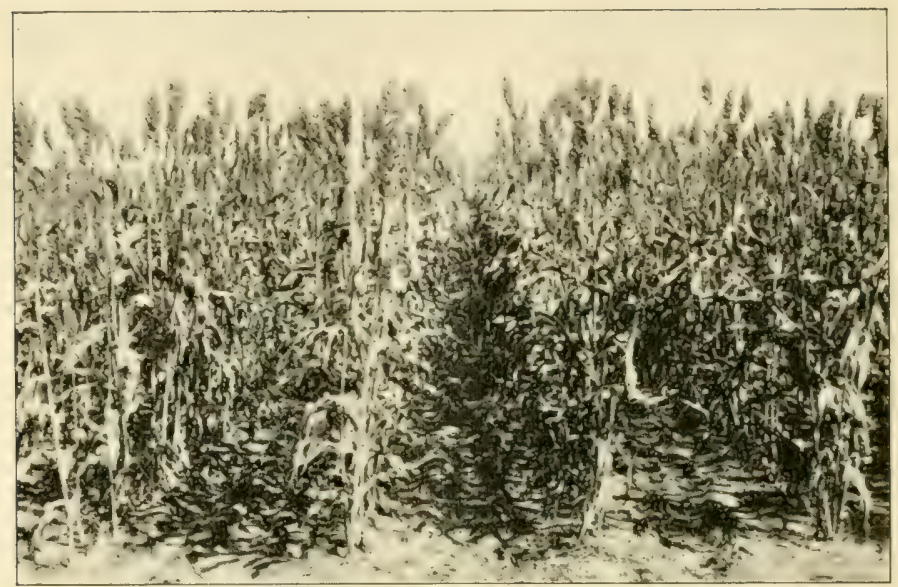

Cereal Invesligations, $U . S . D . A$.

FIG. 55. Field of kafir in western Oklahoma; a good dry-land crop.

grown in the northern part of the dry-farming country. Cotton is also a fairly drought-resistant crop, and so are some varieties of corn.

Much dry farming has been attempted in parts of the West where the rainfall is entirely too light, and many of these dry farms have been abandoned. It would be better for all concerned if the driest of these lands were used only for range purposes. 


\section{CHAPTER SEVEN}

\section{SOIL IMPROVEMENT}

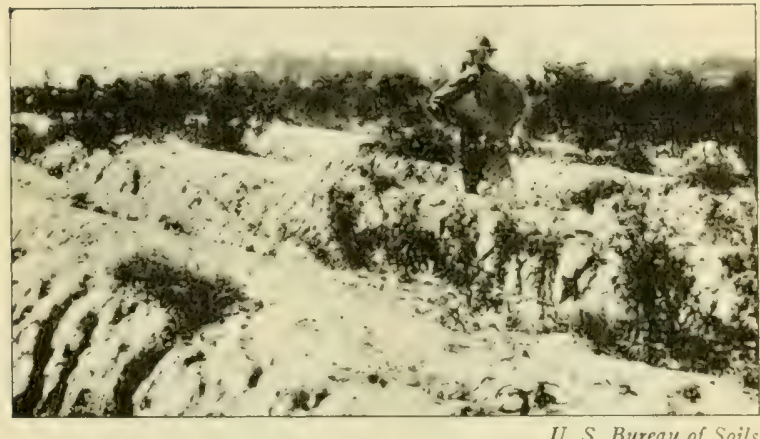

FrG. 56. A washed hillside. Even hardy weeds find it difficult to get started here, because the soil is devoid of humus and has little plant food in it.

\section{WHY NEW SOILS ARE RICH}

EVERy one has noticed hillsides like that shown in Figure 56 , from which more or less of the surface soil is washed away every year. No leaves or other vegetable matter accumulate on such a soil. Even the hardiest weeds grow sparingly in situations like this. But when land is in a level valley such as that shown in Figure 57 , where vegetable matter accumulates not only from the growth on the soil but also from materials washed down from the surrounding highlands, if the land is not too wet, grasses, trees, shrubs, etc., grow in rank profusion year after year, and have done so for thousands of years. What makes the difference between the two? The answer to this question is very important to the farmer. We shall find it in the following paragraphs.

Organic matter defined. Our bodies are composed of parts called organs. Thus the eyes, hands, lungs, 


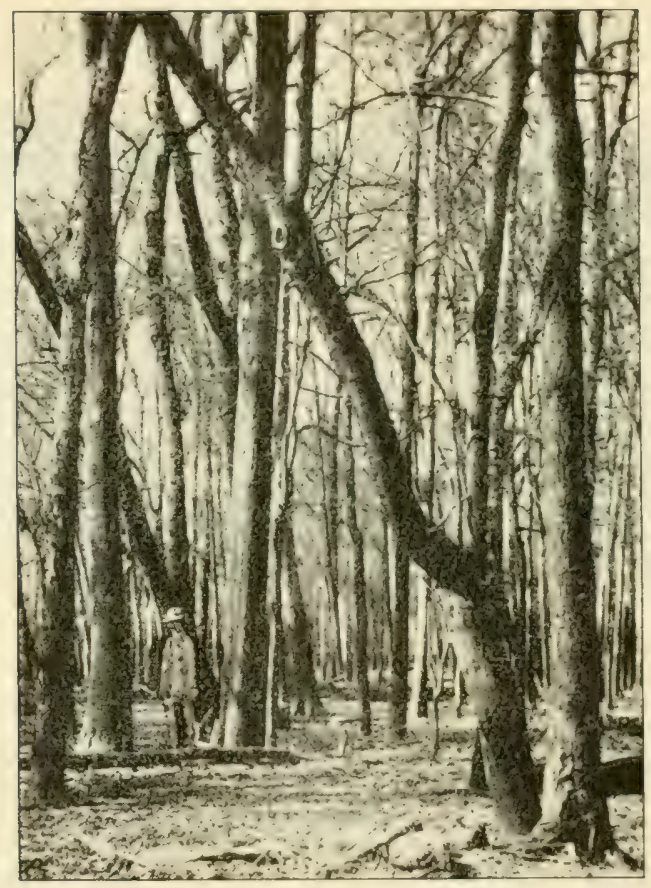

U.S. Bureau of Soils

FrG. 57. Natural growth of trees on rich valley soil. The dense shade, together with occasional floods, prevent undergrowth here. Note the vegetable matter decaying on the surface of the soil.

heart, etc., are organs of the body, each having its own particular office to perform. A body which is thus composed of organs, or parts having different offices, is called an organism, organized body, or organic body. All plants and animals are organic bodies.

Substances that are produced by organic bodies are called organic substances. Thus sugar, starch, horn, etc., 
are organic substances. The materials composing the bodies of plants and animals are referred to as organic matter. This term is still applied to the fragments of their dead bodies as we find them in the soil and elsewhere. Heretofore we have been referring to this kind of material as decaying animal and vegetable matter. We have also called it humus, when it occurs in the soil. Henceforth we shall sometimes refer to it as organic matter in the soil.

Why new soils are rich in humus. In a state of nature, all good soils, if favorably located and properly supplied with moisture, support an abundant growth of grasses, weeds, flowers, shrubs, or trees, or mixtures of these, and have done so for untold ages. Every year the leaves of these plants fall to the ground and become more or less mixed with the surface dirt. In time they rot away and disappear, but meanwhile they have constituted a part of the soil. During the time they were a part of the soil they helped to absorb the rain that fell, and readily parted with this moisture to near-by living plant roots that needed it. The mineral matter they had received from the soil while they were still growing above ground, their dead fragments now slowly give up to the water in the soil that is being taken up by the roots of living plants. Every generation of plants thus lives to some extent on the accumulations of all the generations that preceder it. When a plant dies, its roots and stem also go back to form for a time part of the stock of organic matter in the soil. As they decay, they perform the same offices as the dead leaves just described. 
How mineral plant food accumulates in the soil. Every year there is a small quantity of mineral plant food set free in the soil by the continued action of disintegrating forces on the rock particles of the soil. Growing plants seize upon this and build it into their bodies, along with that obtained from the decaying remains of former generations of plants. Thus, under natural conditions, the soil from year to year increases its stock of available plant food, and becomes richer and richer.

Why washed hillsides are poor and valleys rich. We are now prepared to understand why a washed hillside, although its soil may be naturally just as good as that of the valley, is really very poor, and why plants have such a hard time in getting a start on it. It is lacking in organic matter. On the other hand, the soil of the valley every year has washed down upon it some of the surface soil of the surrounding hills, and this surface soil contains the humus and most of the accumulated plant food the loss of which makes the hillside poor. Valleys are therefore generally rich, unless the soil in them is too sandy, or contains too much clay, or is too wet.

What humus does. It may be well to bring together here what has previously been said about the uses of organic matter in the soil. It is important enough to bear repeating.

In the first place, organic matter helps the soil to hold moisture for the use of growing plants. A pound of well-decayed organic matter in the soil will absorb and hold 2 pounds of water. It also gives up this moisture 
freely to growing plants when they need it. We shall later learn how the growing plants get this water and what they do with it.

It makes the soil porous, so that air and water can circulate freely through it.

It renders the soil friable; that is, easily broken or pulverized. This helps to prevent the formation of clods. A clay soil full of humus can be worked after a hard rain much sooner than one containing little or no organic matter.

Drought has much less effect on crops growing on a soil well stocked with humus than on a similar soil deficient in humus, because such a soil holds more water.

Plant roots can easily thread their way through a soil that is well supplied with organic matter. This enables the growing plant to extend its roots wider and deeper, and thus to find more water and plant food. Of two root systems of the same size, experiment has proved that the one growing in rich soil supports a larger growth above ground than the one in poor soil. Plants in rich soil thus expend less of their energy and food materials in developing roots than do plants in poor soil.

The decay of organic matter in the soil sets free large quantities of carbonic acid gas. This gas is one of the important agencies in the disintegration of rock particles in the soil. It therefore helps to add to the stock of available plant food in the soil.

Finally, this organic matter is a rich storehouse of plant food that has been passed on from one generation of plants to another ever since it was originally set free by the disintegration of rock particles in the soil. 
Wood ashes. When we burn wood in our stoves and fireplaces, we get a certain amount of ashes. Some ashes are obtained when any kind of organic matter is burned (this does not apply to certain pure organic substances, such as sugar, starch, etc.). These ashes are the mineral matter which growing plants get from the soil. It is in solution in the soil water which the roots of growing plants absorb. Some of it is of no use to plants, so far as we know, but enters along with the water and is left in the tissues of the plants. Other parts of it represent substances that enter into the composition of the growing plant. We shall learn what these substances are when we come to study how plants live.

\section{WHAT HAPPENS WHEN MAN BEGINS TO GROW CROPS ON THE SOIL}

We have seen that in a state of nature the soil slowly grows richer by the continued accumulation in it of organic matter and mineral plant food. But when the farmer begins to grow crops on the soil, he changes all this. Instead of leaving the entire crop to rot on or in the soil, he takes away most of that part which is above ground, sometimes even a part of that below. Meanwhile the stirring he gives the soil lets in the air more freely, and this causes the organic matter in the soil to decay more rapidly. Thus, he not only decreases the amount of organic matter added to the soil yearly, but also hastens the decay of what is already there. Is it surprising, therefore, that after a while the soil begins to show signs of approaching exhaustion? A large proportion of the mineral plant food found in the soil is 
contained in the organic matter. The gradual decrease of organic matter in the soil thus means also a decrease in the available plant food. After some years of such treatment, - the length of time depending more or less on the character of the soil and the methods used by the farmer, - the land begins to produce crops like that shown in Figure 58 (page roo), which represents a crop of cotton grown on soil devoted to cotton continuously for half a century with no attempt to replace what was taken from the soil. Is such land really worn out? Can it be brought back to its original state of fertility?

HOW TO BUILD UP OR MAINTAIN FERTILITY OF SOIL

We have just seen how the soil loses its fertility when not properly treated. We have only to reverse the process to restore it. But we cannot leave all our crops to rot on the land, or turn them under, to make humus. We must therefore exercise a little ingenuity in reversing the process that led to the loss of fertility.

By far the most important thing to do in trying to make worn-out land produce good crops is to fill the soil again with organic matter; that is, to increase its humus content. We may do something by adding commercial fertilizers, but they will not do nearly as much good as they would if plenty of organic matter were present to make the soil mellow so that air and water can move freely in it and plant roots can easily grow into every nook and cranny. Since sandy soils are naturally more open than the heavier types, commercial fertilizers are more logical for them than for clay soils when both are lacking in humus. 


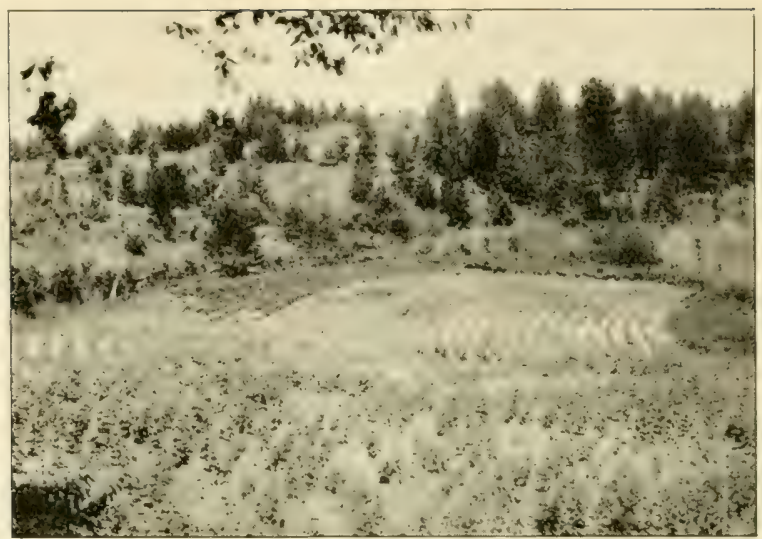

Office of Farm Management (1T, A. Crosby)

FIG. 5 S. The soil of this field has been cropped with cotton for more than fifty years, and nothing has been done to renew the original supply of humus.

\section{WAYS OF RESTORING HUMUS}

Crop refuse. Many crops are grown for their seeds only. The stems and leaves of these plants may be used for humus-making material. Figure 59 shows a field of cotton on a farm that depends entirely on this method. The photographs reproduced in Figures 58 and 59 were taken on adjoining farms, on the same kind of soil. The yield of cotton on the farm shown in Figure 59 is enormous. The owner grows cotton, corn, and oats. He puts back into the soil every fragment of these plants except the parts used for other purposes, which in this case is mainly the seed, and of course the lint of the cotton. When he first began this system, it was necessary to go to the woods and get dried leaves to put on the soil, because his crops did not furnish enough humus-making material. But it was no longer 
necessary to do this when his cotton got to the point where the yield was more than a bale to the acre. From the leares he got a good supply of mineral plant food, which has been passed on from one crop to another for years. No commercial fertilizers are used on this farm.

The straw from an old straw stack, if properly utilized, is worth nearly as much as the same weight of barnyard manure in restoring fertility to land. Where straw, cornstalks, etc., are needed as roughage for stock, the manure made from them, if properly handled, will return to the soil the larger part of the plant food and humus-making material they contain. The farmer thus gets their feed value as well as their manurial value.

In dry countries too much vegetable matter in the soil makes it so loose that it may dry out as deep as it has

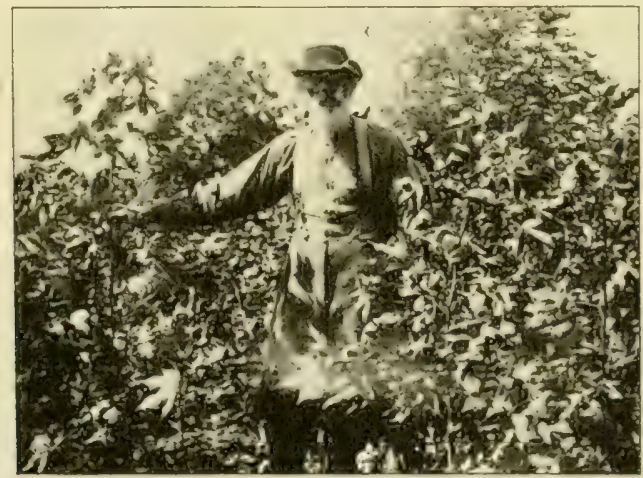

Office of Farm Management (M. A. Crosby)

Fig. 59. This field is only a few yards from the one shown in Figure 58 , and the suil is the same in ty'pe. No manure or fertilizers have been used here, but every. fragment of the stems and leaves of all crops is turned under to make humus. At the beginning it was necessary to use leaves from the forest to get a supply. of humus. A plentiful supply of humus alone makes the difference between this cotton and that shown in Figure 58. 


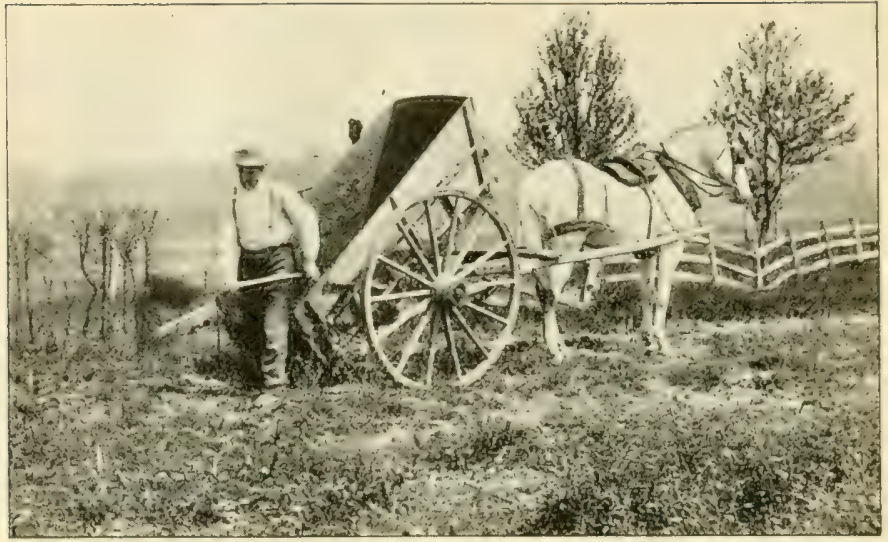

Office of Farm Management

Fig. 6o. The owner of this farm spreads manure on his fields as fast as it is made. He keeps 30 head of stock on 15 acres. His yield of hay is the largest known in this country.

been plowed. The dry-land farmer must therefore use great caution in storing the soil with humusmaking material. Fortunately the soil does not require as much humus in dry regions as it does where the rainfall is heavy, for the bacteria in dry soils, if not too dry, are more active than in wet soils.

Manure. Every farm has some livestock on it. The manure from these should be carefully saved and returned to the land. The best methods of handling manure will be discussed later. Manure should be protected from rains until it is taken on to the fields, after which rain will only wash it into the soil where it is wanted. Figure 60 shows the methods of spreading manure used on one of the best small farms in the country. Here the manure is spread daily, and there is not enough of it at one time to justify the use of a spreader. When large quantities 
of manure are to be handled, it is better to use a manure spreader (Fig. 6r).

Sod crops. Another way to put humus into the soil is to grow a sod crop in the rotation. Timothy and clover, mixed, constitute the most common sod crop of the North. In the West, alfalfa takes the place of this mixture. It is not, strictly speaking, a sod crop, but for reasons that will be given later it is quite as valuable a means of restoring fertility to the soil as timothy and clover, if not more so. In the East, however, where the soils are often acid, it will not grow on poor soil. The South has no satisfactory sod crop. Johnson grass and bermuda make excellent sods, but their weedy character makes it difficult to utilize them for this purpose. Plowing under a good, heavy growth of sod adds so much humus to the soil that the effect can be seen for several years in the increased yield of crops.

Green manures. A green crop plowed under for the purpose of improving the soil is called a green manure.

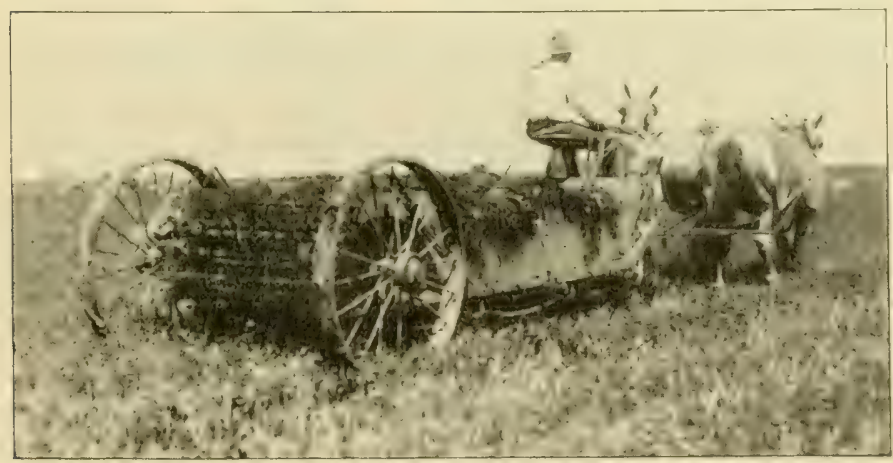

Office of Farm Management (J.A. Drake)

Fig. 6r. A manure spreader at work. 


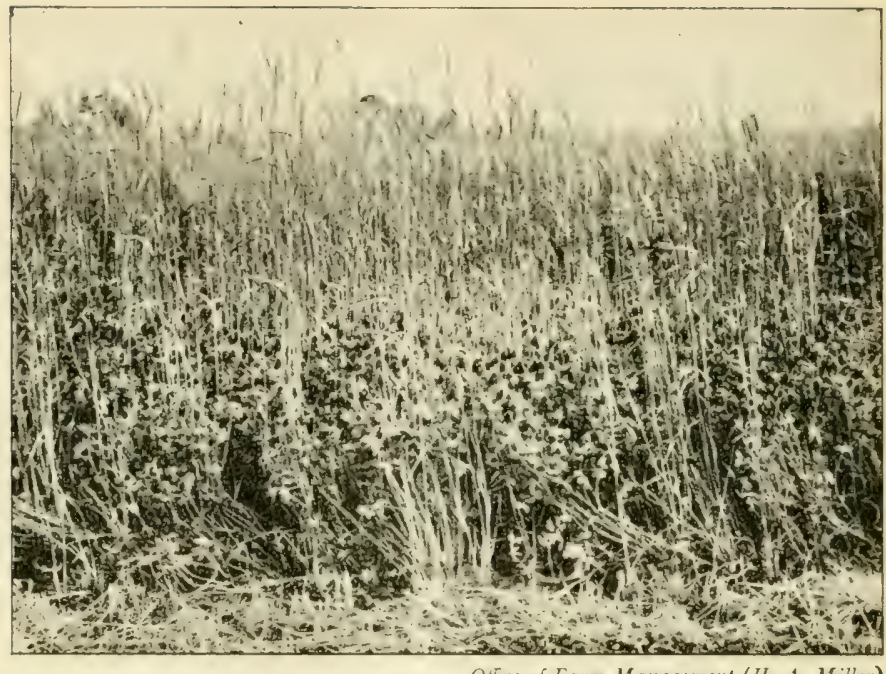

Ofĭce of Farm Management (II. A. Miller)

FiG. 62. Crimson clover and rye grown as a green manure crop in one of the Atlantic coast states. It will be plowed under in time to plant corn.

Where other means of putting humus into the soil are lacking, there is a long list of crops suitable for use as green manures. Usually these crops can be grown as catch crops; that is, they can be grown in the winter between two summer crops, or sown in a cultivated crop like corn after the cultivation is finished. Thus, cowpeas or soy beans may be sown in cornfields to plow under after the corn is harrested; or they may be pastured and their remains turned under. There are several crops that may be sown in the early fall and plowed under the next spring in time for a summer crop. Some of these are rye, crimson clover, bur clover, and hairy vetch. Rye and hairy retch may be grown almost anywhere in this country. Crimson clover does well in 


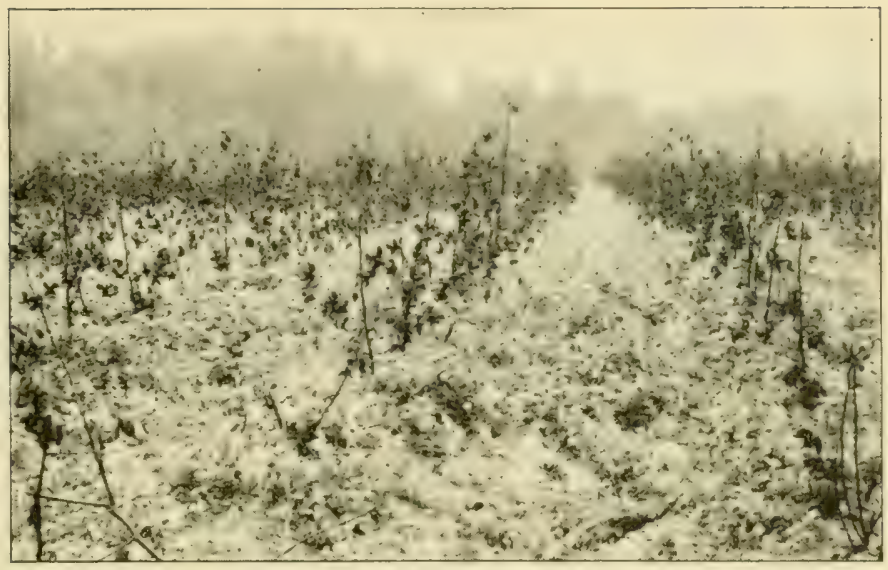

Office of Farm Management (J.S. Cates)

Fig. 63. Crimson clover sown as a green manure crop in a North Carolina cotton field. It will be turned under in the spring in time to plant cotton again.

most parts of the Atlantic coast states, and bur clover in the South. Along the Atlantic coast rye and crimson clover are frequently sown together as green manure (Fig. 62). Figure 63 shows a North Carolina cotton field in which crimson clover was sown in late summer, to be plowed under in the spring in time to plant cotton again.

In the West alfalfa, and in the East red clover, are frequently turned under for green manure, with excellent results. Figure 64 shows clover sown for this purpose. It was sown on winter rye in the spring. The rye had just been cut when this picture was taken, and a nice growth of young clover is coming on. After it had made a good growth the next spring, it was to be plowed under for the benefit of some young apple trees, which are too small to be seen in the picture. 


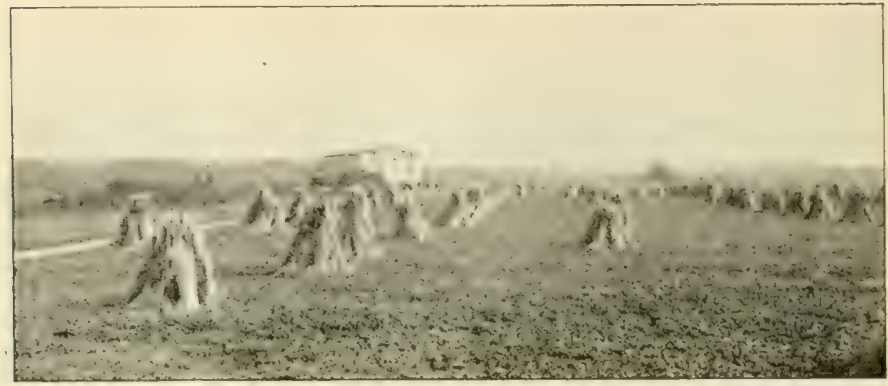

Office of Farm Management

FIG. 64. Red clover following rye. The clover will be plowed under the next spring for the benefit of young apple trees too small to be seen in the picture.

The value of green manure crops is very clearly shown in Figures 66 and 67 . These fields of corn grew on adjoining farms and in the same kind of soil. The only difference in their treatment was that the field shown in Figure 67 had had several crops of green manure turned under in it, had been plowed deeper, and tilled with more care. The better field does not show to full advantage, because at the time the picture was taken the tops of the cornstalks had been cut off for fodder.

Where the land is so poor that it would not pay to grow a crop on it, a very good plan is to sow it thickly to corn or sorghum, or any other crop that will make a rank growth, and plow this crop under when it has reached its full growth. This will put a great deal of humus into the soil, but it is an expensive method.

Weeds as green manure. In extreme cases, where the land has become so poor that it does not pay to cultivate it at all, it may be left to grow up in weeds for a few years. Each crop of weeds will add some humus to the soil, so that in time the soil will be restored to a 
considerable degree of fertility. Figure 65 shows a field undergoing this method of recuperation. In regions where this method is practiced, farmers call fields like that shown in the figure "resting" fields. This practice is not necessary where farmers give proper attention to the matter of keeping the soil supplied with humus.

The use of legumes as a means of restoring soil fertility will be discussed later.

\section{SOIL SOURNESS, AND REMEDIES}

The word "sweeten" used in two senses. Sourness is due to the presence of some kind of acid. Thus, sour milk contains lactic acic. Vinegar contains acetic acid. Sugar sweetens, not by removing the sourness of the acid, but by disguising its taste. But there are sub-

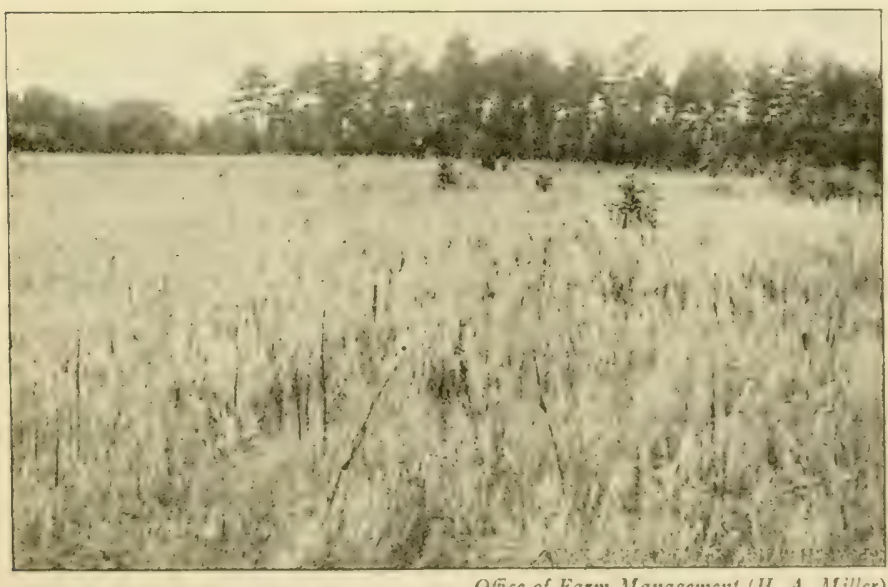

Ofince of Farm Management (U. A. Miller)

Fic. 65. A "resting" field. The shiftless farmer's method of adding humus to the soil. 


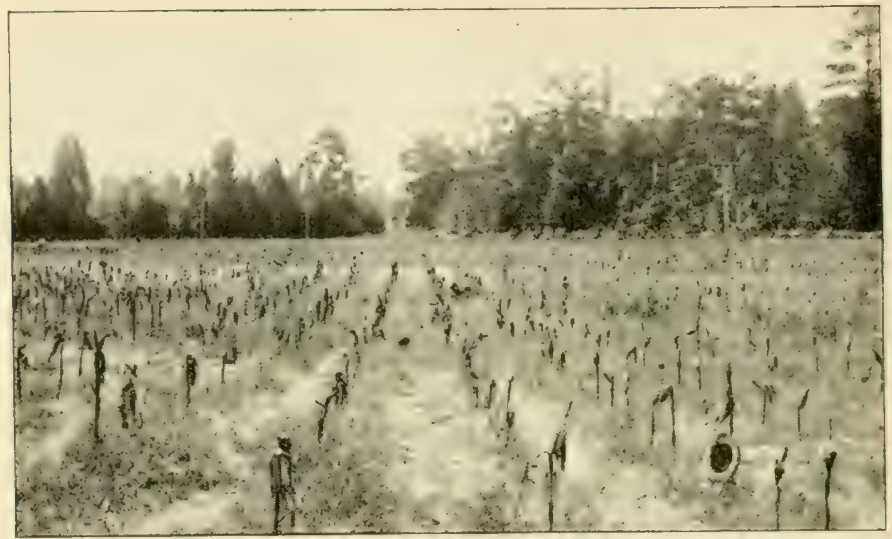

Office of Farm Management (H. A. Biller)

FIG. 66. Corn on land very poor in humus; same neighborhood as Figure 67. Yield, 8 bushels per acre.

stances that change acids into new substances that are not sour. These "sweeten " by removing the sourness. Ammonia, lye, and lime are familiar substances of this kind. (See experiment with sour milk at end of this section.) Such substances are said to be alkaline. There are thus two ways of sweetening a sour substance. First, the taste may be disguised by adding sugar; second, the sourness may be destroyed by adding an alkaline substance. The term "sweeten" is used for this latter case merely for want of a better word.

Acids and alkaline substances in the soil. As we already know, soil consists mostly of rock particles, but a small part of any good soil consists of decaying animal and vegetable matter. The principal substances composing the rock particles of the soil are insoluble, or only slightly soluble, in water. Most of these difficultly 


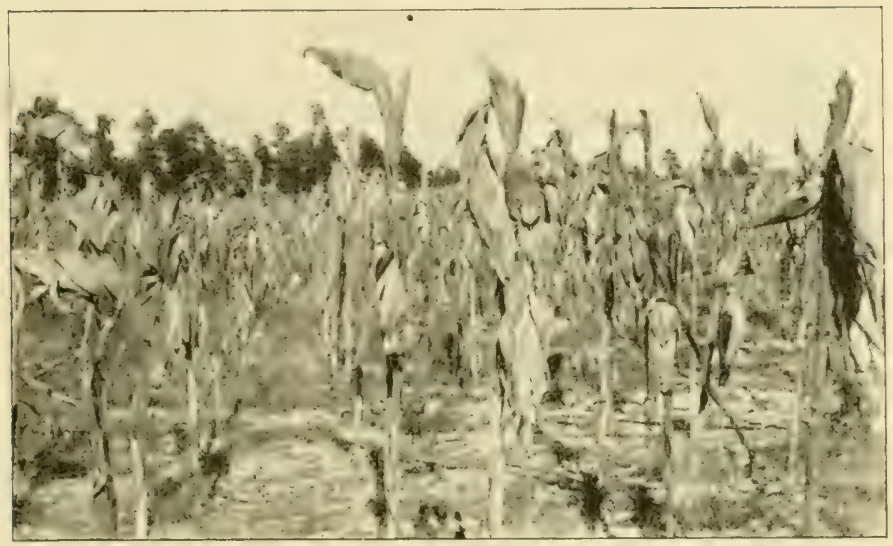

Othice of Farm Manasement (II . 1. Miller)

FIG. 67. A field of corn on the same kind of soil as that shown in Figure o0. The difference is due to the use of crimson clover as green manure, deep plowing, and good cultivation. Yield, 45 bushels per acre.

soluble substances of the rock particles are slightly acid in their nature. But there are soluble substances embedded in the rock particles. It also happens that most of these soluble substances are more or less alkaline in nature. It is necessary to remember these facts in order to understand the next few pages.

When vegetable matter decays in the soil, it may give rise to either alkaline or acid substances, accorling to the conditions under which the decay takes place. If there is plenty of air present, at least some of the compounds resulting from the decay will be alkaline. In fact, ammonia, one of the strongest alkalies, is produced under such circumstances. But if the decay takes place with a very limited supply of air, the resulting compounds are usially of an acid character. We 
shall see directly the application of these principles to the soil.

How alkaline substances accumulate in the soil. We have already learned that most of the forces which crumbled the original rocks of the earth's crust are still at work, just as they have always been. They work on the little rock particles of the soil just as they do on the big rocks that project from hillsides and mountain tops. When a piece of rock is cracked or broken, new surface is exposed, and the soil water can extract from it a small amount of soluble matter. In this way small quantities of soluble mineral matter are continually being set free in the soil. Most of these soluble substances, as stated above, are alkaline, rather than acid, in nature. Some of them are valuable as plant food, as we shall learn when we come to consider how plants live.

Why soils are alkaline in dry regions. In dry regions, where there is never enough rain to wet the soil more than a few feet deep, this soluble matter remains in the soil. This causes the soil to be alkaline. When these substances accumulate in too great quantity, especially when they are brought to the surface by water evaporating there, we have the dreaded alkali.

Why soils are acid in regions of heavy rainfall. In regions where the rainfall is so heary that the soil becomes wet clear down to the level of the ground water, which is the level to which wells must be dug to find water, there is no chance for these soluble substances to collect in the soil. They are dissolved in the soil moisture, and such of them as are not taken up by growing plants 
in the water their roots absorb are washed down to the general level of the water in the ground. This water finally flows out at springs, and sooner or later finds its way to the ocean, to which great reservoir it carries the mineral matter it dissolved out of the soil. This is the way the ocean became salty. All permanent bodies of water that have no outlet are salty for the same reason.

When the soil is kept washed nearly clean of these soluble, alkaline substances, it becomes more or less acid, for the reason that the more insoluble portions of the soil are for the most part slightly acid in character. This condition exists in most soils that receive more than about 40 inches of rainfall a year, though there are some localities where there is so much lime in the soil that it remains alkaline even with much greater rainfall. Where the rainfall is less than about 30 inches, the soil is usually alkaline. Between these extremes it is seldom very acid or very alkaline.

Effect of standing water on soil acidity. When the soil becomes water-soaked, the air cannot circulate through it. We have already seen that under such conditions the decay of vegetable matter in the soil gives rise to acid substances. Hence soils that need drainage are usually acid.

Effect of too great compactness of the soil. When the soil becomes so compact that air cannot circulate freely through it, the conditions in it are similar to those in soils needing drainage. Hence compact soils are liable to be sour.

Effect of plowing under a green crop. When a green crop is plowed under, it ferments much after the man- 


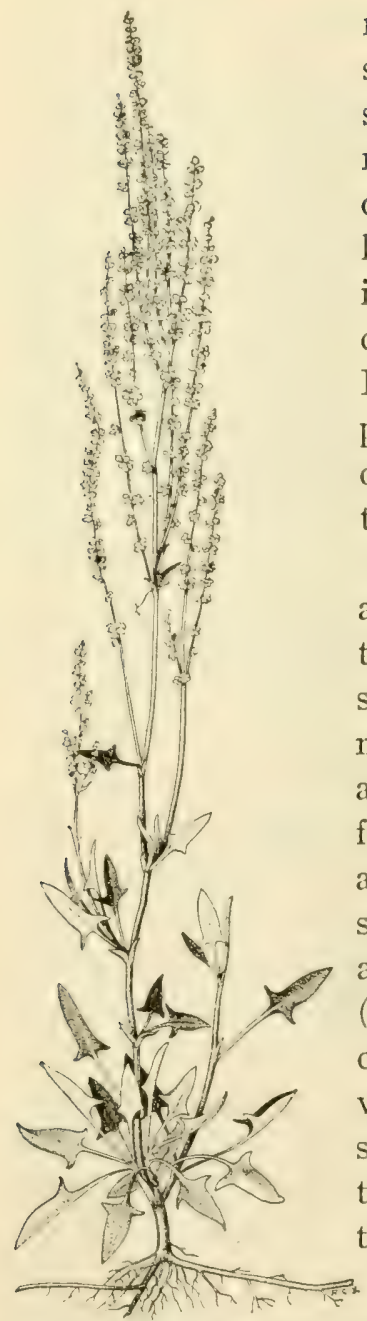

Fic. 68. Sorrel, a weed that luxuriates in sour soil. ner of cabbage used in making sauerkraut. This makes the soil sour for a little while. But sourness caused in this manner soon disappears and seldom does any harm. This kind of sourness is, in fact, an excellent thing for the common Irish, or white, potato. It prevents the development of potato scab if the germs of this disease happen to be present in the soil or on the seed potatoes.

Signs of soil acidity. It is not always easy to tell from observation when a soil is sour, but in some cases it may be done. Common red clover, alsike clover, and alfalfa all dislike acid soils, and frequently fail on them. Potatoes are not liable to be scabby on such soils unless the seed potatoes are very badly infected. Sorrel (Fig. 68) likes acid soils and is a common weed on them. It gives very little trouble on alkaline soils. The presence of moss on the ground is a pretty sure sign that the soil is acid.

A test for acidity. There are many substances that are of one color in the presence of acids and 
another in the presence of alkaline substances. You have all seen the colored veins in the leaves of certain varieties of cabbage. The coloring matter in these veins is of this kind. It is blue when alkaline and red when acid. The substance known as litmus behaves in the same way. Paper soaked in litmus may be obtained at any drugstore. With it the experiment with litmus described at the end of this section should be tried. This is a very good way to determine whether the soil is acid.

How to correct acidity of the soil. When acidity is due to too much water in the soil, the remedy is drainage. Where it is due to the fact that the soil is too compact, loosen up the soil by plowing and other tillage operations and by the addition of humus-making material. Acidity due to the plowing under of a green crop soon cures itself. For acidity due to the leaching out of the soluble mineral matter of the soil, - the common cause of acidity in regions of heary rainfall, - lime is the commonly used corrective.

Forms of lime used. Limestone $\left(\mathrm{CaCO}_{3}\right)$ is the most common form of lime. When limestone is kept red hot for several days, it gives up part of its substance and quicklime $(\mathrm{CaO})$ remains. The part given up passes off into the air as carbonic acid gas $\left(\mathrm{CO}_{2}\right)$. When quicklime is mixed with water, the two substances unite into one substance known as slaked lime, or water-slaked lime $\left(\mathrm{CaO}_{2} \mathrm{H}_{2}\right)$. If either quicklime or water-slaked lime is exposed to the air for a week or so, it again unites with the carbonic acid gas of the air and becomes airslaked lime $\left(\mathrm{CaCO}_{3}\right)$. Limestone and air-slaked lime 
thus have the same composition, the difference between them being that one is a solid mass while the other is a fine powder.

Marl is another form of lime. It is merely dirt with a great deal of lime (limestone) in it. In localities where it occurs, marl is much used as a corrective of soil acidity. Its use by farmers dates back many hundreds of years. In olden times, many English farmers, when they first learned the value of marl, put as much as a hundred cart loads of it on an acre.

Oyster shells are composed of the same substance as limestone. They are much used by farmers near the great oyster-producing centers around Chesapeake Bay and other places where oysters abound. They are usually ground, or sometimes burned, before being applied to the land.

Land plaster is another compound of lime. It also contains sulfur. Where it can be obtained cheaply, it is a valuable soil amendment. Land plaster, often called " gypsum," was much used in this country a hundred years ago, but it has now become too expensive for general use.

Where it is not too expensive, finely ground limestone is a good form of lime to use on the soil. In some places slaked lime is more available.

Amount of lime to use. Unfortunately there is no absolute rule governing the amount of lime a soil needs, if it needs any. Much depends on the previous treatment of the soil. In many places a ton of finely ground limestone per acre once in five or six years is sufficient. The farmer must learn how much to use by trial or by 
observing the experience of his neighbors. Sometimes he can get valuable advice on this point from his state experiment station.

Soils may need lime even when there is limestone rock only a few feet below the surface. On the other hand, there are soils, even in regions of heary rainfall, that contain too much lime. This is true of some areas of the black prairie soils of Alabama, Mississippi. Arkansas, and Texas. These soils are heavy clay, and water does not circulate through them readily enough to wash out the lime they contain. At the same time they absorb water readily, and give it up to plants freely.

If in doubt, try some lime.

Effect of lime on soil bacteria. Some of the most useful bacteria that live in the soil will not thrive in an acid soil. The use of lime in such soils is highly beneficial to these bacteria. We shall later learn what service the soil germs render the farmer.

Effect of lime on the texture of the soil. Lime has the effect of causing the tiny soil particles to cling together in large masses. Muddy water can be rendered clear by adding a little quicklime to it. (See experiment at end of section.) With lime present in the water, the fine particles of earth that cause the muddiness will come together and the larger masses thus formed will settle to the bottom, leaving the water clear.

Lime has the effect of rendering a clay soil more open and porous, because it makes it lumpy. This allows air and water to circulate more freely and thus improves the soil. Strangely enough, lime improves 
sandy soils also, because the formation of lumps in this kind of soil makes it less easy for air and water to pass between the particles that are stuck together.

Effect of lime on certain rock particles in the soil. Lime has a corroding action on certain kinds of rock particles in the soil, causing them to give up some of the plant food they contain. It thus adds to the store of available plant food in the soil.

Effect of lime on organic matter in the soil. By favoring certain bacteria which live on the organic matter in the soil, lime causes this organic matter to decay more rapidly. This sets free the plant food contained in the organic matter. But just here is a danger. If we use much lime and then fail to keep the soil well supplied with humus-making material, the last state is worse than the first, for the soil will soon have no humus in it. There is an old proverb which says that lime enriches the father but impoverishes the son. This trouble can be avoided by adding plenty of organic matter to the soil.

\section{COMMERCIAL FERTILIZERS}

The methods of keeping up soil fertility discussed above are within the reach of practically every farmer, and for the most part require only a little more labor on his part. He may have to spend a little money for lime, but in many places he can dig this out of marl beds or get it by burning limestone, which is often found on the farm. In any case lime is usually cheap.

But there are cases in which it is advisable, or even necessary, to use commercial fertilizers. As we have already learned, the marine sediment which constitutes the 


\section{Soil Improvement}

soil of the Atlantic and Gulf coast country consists largely of the most insoluble kinds of rock particles. Most of these soils are also more or less sandy, and organic matter rots out of them rapidly. Hence they do not in general contain as liberal a supply of plant food as many other soils. In this region commercial fertilizers are very generally used, - more so than in any other in this country. In central and southern Texas, where the rainfall is light, these soils are well supplied with soluble mineral matter because there is not enough rain to wash it out of the soil as it forms.

Because of the great number of soil types, all differing more or less in their fertilizer requirements, the fact that the requirements of the same soil are not the same from year to year, owing to difference in treatment in different years, and that the same crop may need different kinds of fertilizers under different conditions of soil and climate, it has never been possible to lay down definite rules for the use of fertilizers except for particular cases ; and there are not many of these cases for which the best practice is known.

Further treatment of the fertilizer problem will be given when we have learned more about how plants grow. For the present we must be content with the following general statements:

If a soil has very little humus in it, it may be necessary to use some commercial fertilizers in order to produce humus-making crops. At the same time, on most soils commercial fertilizers produce much less effect when humus is lacking than they would with a plentiful supply of humus. 
For crops like fruit, market vegetables, etc., the products of which bring large sums per acre when prices are good, it usually pays to use fertilizers.

Sandy soils, which are open and porous, usually have little humus in them. The air gets into such soils so easily that the bacteria that cause decay are very active when they have anything to live on. Fertilizers are nearly always necessary on such soils, but quite frequently they do little or no good unless plenty of humusmaking material is added to the soil.

The fertilizer problem is at best a local one, and the farmer should keep in close touch with his state experiment station in regard to the use of fertilizers. He should also pay the closest attention to the practice of those farmers in his locality whose crops yield the best, provided his soil is the same as theirs.

The quantity of fertilizers to use in any given case depends on the character of the soil, on the kind of crop grown, on the cost of fertilizing materials, and on the price of the product produced by the crop. When fertilizers are cheap and when prices for crop products are high, it pays to use more fertilizer than when the opposite conditions prevail.

\section{Things to Observe}

Examine the leaf mold in a forest if one is near by. Note the gradual change from fresh leaves on top to decayed leaves at the bottom where the layer of leaves gradually merges into the soil. Note how loose and friable the soil is under this carpet of leaves. Would not such a soil absorb rain water readily?

Observe whether water runs on the surface of the ground 
in a forest when a hard rain comes, as it does where the ground is bare. Do you find as much evidence of surface washing in the forest as elsewhere? Why is this?

Examine the soil on a washed hillside and also in a level valley. In which do you find the most vegetable matter?

\section{Experiments}

r. Litmus test for acidity. Get some blue litmus paper from a drugstore. Be careful not to touch it with the bare fingers, for this would change its color. Five cents' worth is ample for many experiments. Dig down in the soil to be tested, till moist soil is found. Take up a handful of the moist soil, separate it into two parts, place a small piece of litmus paper on one of the parts and then press the other part against it for a few seconds. Then examine the litmus paper to see if it has changed color. If the soil is very acid, the litmus paper will turn quite red.

2. Muriatic acid test for limestone. Get five or ten cents' worth of muriatic acid at the drugstore. Pour a drop or two on a piece of limestone. The action of the acid produces bubbles of carbonic acid gas. Test samples of marl or other soil supposed to contain lime to see if they will foam in the same manner. They will if they contain much limestone. Try a little of the acid on an oyster shell. The symbol of muriatic acid is $\mathrm{HCl}$; of limestone, $\mathrm{CaCO}_{3}$. When the two are brought together the following reaction occurs:

$$
2 \mathrm{HCl}+\mathrm{CaCO}_{3} \rightarrow \mathrm{CaCl}_{2}+\mathrm{H}_{2} \mathrm{O}+\mathrm{CO}_{2} \text {. }
$$

In other words, two molecules of the acid and one of limestone tear each other apart, the atoms reuniting to form one molecule of chloride of lime, one of water, and one of carbonic acid gas. It is the formation of the gas and water that causes the bubbles.

3. Effect of lime on muddy water. Take two glasses of water from a muddy pond and put a little quicklime or slaked lime into one of them. The lime will cause the little particles 
of earth to cling together, and the larger masses thus formed will soon settle to the bottom, leaving the water clear. It may take several hours to get the complete effect. Muddy water for this experiment may be had by stirring some clay soil into water. Why should the water used in this experiment not be "hard" water?

4. Effect of alkaline substances on acids. Pour, drop by drop, into a glass of sour milk a solution of ammonia, concentrated lye, caustic potash or soda, or strong limewater, stirring meanwhile to mix the milk and the substance added to it. It is a good idea to put a piece of litmus paper in the milk. The milk will turn it red. When enough of the alkaline substance has been added, the litmus paper will turn blue. This experiment can be performed without the use of litmus paper, but is more instructive with it. When the acid in the milk has all been changed into non-acids by the alkaline substance, the milk will assume the appearance and consistency of ordinary sweet milk; that is, it will lose its "clabber" and its sour taste, though it may not taste exactly like ordinary milk because of the substance added in the experiment. The alkaline substance unites chemically with the acid, forming substances that are neither acid nor alkaline. 


\section{PART TWO - THE PLANT}

\section{CHAPTER EIGHT}

\section{PLANT ORGANS AND THEIR USES}

Kinds of organs. We have already learned that plants are organic bodies, which means that they are composed of parts, or organs, each having its own particular work to do. Plants have three principal kinds of organs, - roots, stems, and leaves. Flowers are only modifications of stems and leaves, as we shall see later.

Roots. The principal business of plant roots is to absorb water from the soil, and along. with it the plant food materials dissolved in this water. They also serve to hold the plant in place. Roots differ from stems in the following particulars: they generally grow below ground, while stems generally grow above ground; but there are exceptions to both these statements. Underground roots, near their ends, are covered by slender, hairlike projections, called root hairs. It is these root hairs that absorb water from the soil. We shall learn more of them presently. Stems have no corresponding outgrowths, though many stems are covered with fuzz or bristles, which, however, serve a different purpose. Stems produce leaves and buds at regular intervals; that is, the leaves and buds on stems are arranged according to a definite plan. Roots produce neither leaves nor buds, though roots that live from year to year are generally capable of producing sprouts from any part of their surface. 
Leaves. The leaves of plants have several important offices. In the first place, plant roots absorb enormous quantities of water from the soil, amounting to from 300 to 800 pounds for every pound of growth made by the plant (not counting the water in the plant). Most of this water evaporates at the leaves, and thus passes off into the air as water vapor.

In the second place, leaves absorb carbonic acid gas $\left(\mathrm{CO}_{2}\right)$ from the air, and thus obtain the carbon which makes up so large a part of the substance of the plant. It is this carbon that makes charcoal when any kind of plant material is heated in the absence of air, so that it cannot burn.

Finally, and most important of all, the green coloring matter in leaves and young stems has the power, when light is shining on it, of splitting apart the carbon and oxygen of which carbonic acid gas consists, and of causing the carbon thus liberated to unite with water, thus beginning the formation of the various substances that go to make up the plant. No one yet knows just how light, acting on the green substance in the leaves, accomplishes this work. But the life of all ordinary plants and of all animals is absolutely dependent on this process. Without it plants could not grow, and we should have no food. If you study Plant Physiology, you will learn more about this very important matter.

Stems. The principal work of stems and their branches is to convey water and plant food material from the roots to the leaves, and to carry back to the growing parts of the plant the plant food manufactured 
in the leaves. In trees, the water and plant food materials obtained from the soil move upward through the sapwood, there being channels specially provided for this purpose. The plant food manufactured in the leaves moves downward in a thin layer of material (the cambium layer) between the bark and the wood. The heartwood of a tree is dead, and the only reason it remains sound is that it is protected by the bark and sapwood from the bacteria, fungi, etc., that cause decay. The heartwood was once sapwood.

In many kinds of plants there are special channels scattered throughout the stems for carrying up water and plant materials from the soil, and others for carrying the manufactured food back from the leaves. These channels in a cornstalk are located in the fibers in the pith. The story of these channels is interesting, but it belongs to botany.

It will be noted that large plant stems are usually branched and that the leaves are found chiefly out near the ends of the branches, especially if the branches are close together. This is to give each leaf a chance to get its share of sunlight and air. There are few or no leaves inside a dense tree top, just as there is little or no undergrowth in a dense forest, and for the same reason.

\section{MODIFICATIONS OF PLANT ORGANS}

Flowers. The stem of a flower is a modified branch, and the other parts of a flower are modified leaves. The business of flowers is to produce seed. We shall learn more about them when we come to study how seeds are produced. 
Buds. Buds are rudimentary branches; that is, they are branches at a very early stage of development. Practically every leaf has a bud somewhere near its base, usually just above it. The leaves on some trees have several buds at their base. Note the position of these buds on a number of plants, especially trees. The bud does not really belong to the leaf, but is an outgrowth of the stem to which the leaf is attached.

On stems that live only one season, the parts of the bud are merely rudimentary leaves, many of which never grow to maturity. On stems that live from year to year, the outer layers of the bud are rudimentary leaves ("bud scales") modified into a form that serves to protect the delicate inner portions of the bud. The bud scales do not develop into full-grown leaves, but fall off when the bud begins to grow into a branch. The little leaves in the center of the bud later become ordinary leaves.

On trees, the buds that form one year develop into branches (or flowers) the next year, or sometimes later, or sometimes they never develop further. By picking buds to pieces you can soon learn to tell fruit buds (those that will develop into flowers) from leaf buds (those that will develop into ordinary branches). After you have learned the trick you can usually tell the two kinds apart without picking them to pieces.

Thorns, briers, and spines. Thorns are modified branches, as can easily be seen by examining them when they are young and still growing, on any tree that produces thorns. At this stage thorns have little leaves on them, just as ordinary stems do. 
Briers, such as are found on rose bushes, blackberry vines, etc., are outgrowths of the bark.

Spines are sharp projections growing out from the ends of the principal branches of the framework of a leaf. In the prickly pear, and other cacti, the entire leaf is reduced to the form of a spine, while the stems of the plant are modified into leaflike organs and serve the purpose of leaves.

Rootstocks. Rootstocks are stems that grow underground. (See Figure 98, page I86.) They have no root hairs on them and do not absorb water as roots do. They also have rudimentary leaves on them with a bud at each leaf, which roots do not have. Some of the worst weeds in the country, such as Johnson grass in the South and quack grass in the North, owe their weedy tendencies to the fact that they produce long, vigorous rootstocks. The common Irish, or white, potato has these underground stems, thickened portions of which are the part of the plant we eat.

\section{FOOD STORAGE IN PLANTS}

When an animal eats more than it needs, a part of the food is ordinarily converted into fat, which is stored up in the body to be used in case of hunger. Plants store their surplus food mostly in the form of starch; sometimes as sugar; sometimes in other forms. In many kinds of plants the part of the plant in which this storage of food occurs becomes swollen and fleshy. In the sweet potato, turnip, beet, carrot, etc., the starch or sugar is stored in the root. In the Irish potato it is stored in thickened portions of underground stems, 
constituting tubers. In onions the bases of the leaves become thick and fleshy, constituting a bulb. Onion "sets" are buds with the scales (rudimentary leaves) swollen with stored food. The sets take the place of flowers on the plant. The timothy plant has a swelling at the base of the stem, in which considerable nutriment for next year's growth is stored. If grazed so close that these swellings are destroyed, the stand soon dies out. Numerous other methods of storing food are found in the plant world; the student should look for them in the plants with which he is familiar.

All plants with woody stems store food in the sap of their stems, branches, and roots. Maple sugar is made from sugar thus stored. It is this stored food that enables the tree to throw out new leaves and flowers in the spring. Near my window a large maple tree this spring lost its young leaves by frost; it threw out a second set smaller than usual.

All plants store more or less food in their seeds, so that the germinating seedling may have something to live on until it develops roots and leaves.

In all the cases of food storage noted above, the purpose is to furnish nutriment to the plant with which to start growth the next year, before new leaves are developed.

All kinds of fleshy fruits represent stored food; but in this case the purpose is often to tempt animals to eat the fruit and thus scatter the seeds of the plant. Man has taken advantage of this property of plants and by long-continued selection of desirable variations in quality has produced many fine fruits. In fact, all the above 


\section{Plant Organs and Their Uses}

methods of storing food to which plants resort have proved useful to man.

\section{Things to Observe}

Examine the ends of freshly cut sticks and logs. Note the dark heartwood at the center and the surrounding sapwood. How large does a tree get before it begins to have heartwood? Study the bark of trees and shrubs. Note the outer, dead portion, the middle live bark, and the cambium layer between wood and bark. When the plant is growing vigorously, the cambium layer contains much plant food in a slimy, sirupy condition. It is at this time that bark peels most readily. Note also the rings of growth in the wood. One of these forms during each growing period, usually one a year, but two may form in one season if the middle of the season is very dry. Where is the new layer formed?

Examine a tree with a dense top, in summer. Where are nearly all the leaves? Why is this?

Note the location of buds with reference to leaves. Note this especially on sycamore and on hickory trees if any grow in the vicinity. How many buds do you find at the base of each leaf?

Study the structure of several kinds of buds. See if you can tell fruit buds from leaf buds on fruit trees. Fruit buds are those that develop into flowers, and later into fruits.

Note the arrangement of leaves and buds on the stem of the plant. Is there any regularity in this arrangement? Is it the same on all kinds of plants?

Note that buds have wood at the center, and that this wood connects with the wood of the stem on which the bud grows. Note the pith in this wood. Does the pith of the wood in the bud connect with that of the stem? Are the bases of leaves connected with the wood of the stem on which they grow, or only with the bark? 
Examine young growing thorns. Can you find little leaves on them? Is the arrangement of these leaves similar to that of other leaves on the same plant?

Examine the briers on rose and blackberry bushes. To what are they attached, bark or wood?

On spiny leaves note location of spines with reference to the ends of the branches of the framework of the leaves.

Examine the underground parts of such plants as the Irish (white) potato, Johnson grass, quack grass, and blackberry bushes. Distinguish between roots and underground stems (rootstocks). Do you find rudimentary leaves and small buds on the rootstocks?

Examine all plants you find with parts swollen from stored food. Note in what part of the plant the food is stored, whether root, stem, rootstock, leaves, base of leaf, etc. 


\section{CHAPTER NINE}

\section{HOW PLANTS LIVE}

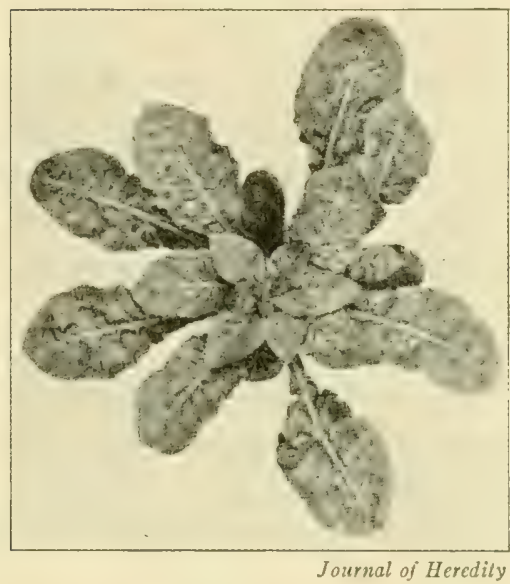

FrG. 69. Stage of growth reached by a winter annual in late fall or early winter.

Length of life. Plants which grow from seed, mature, produce seed, and then die, root and branch, all in one growing season, are called ammuls. Name sereral annuals among our common field and garden crops. Plants that germinate in the fall, form a "rosette" of leaves at the surface of the ground (Fig. 69), live in the rosette stage over winter, grow to maturity the following summer, produce seed, and then die, root and branch, are called winter anmuls. Winter wheat is a winter annual. Plants like beets, turnips, cabbage. etc., that grow one full season but do not produce seed till the next, and then die completely, are called bicmuials. In our climate many of these biennials must be put in storage in winter in order to preserve them. A plant 
which lives several years is said to be a perennial. Examples are alfalfa, bermuda grass, timothy, and all kinds of trees.

Perennials are of two kinds. In one kind both root and stem live from year to year. In the other only the root lives over, new stems rising from buds formed the previous year at the point where root and stem meet; that is, from the "crown" of the plant.

\section{FACTS FROM OTHER SCIENCES}

Before we can understand how plants obtain their food and drink, and how they breathe, we must learn a few facts from other sciences. At this point you should review carefully the facts from chemistry given in Chapter One.

Air. The air is not a chemical compound. It is a mixture of several gases. About four fifths of it is nitrogen, $\mathrm{N}_{2}$. Most of the other fifth is oxygen, $\mathrm{O}_{2}$. Carbonic acid gas, $\mathrm{CO}_{2}$, constitutes about four hundredths of one per cent. Small quantities of other gases are present. There is always more or less water vapor in the air, but the amount varies greatly. Clouds are formed from this vapor. Rain, dew, and frost all come from this source. Water vapor gets into the air by evaporation from water surfaces everywhere.

The air found in the capillary spaces of the soil contains less oxygen and much more $\mathrm{CO}_{2}$ than does the air above ground. This is because one of the most important of the chemical changes that take place in the decay of organic matter in the soil is the chemical union of oxygen from the air with the carbon contained in the 
organic matter, forming $\mathrm{CO}_{2}$. The chemical changes that occur in decaying organic matter everywhere are due to the action of bacteria and other minute organisms, of which we shall learn more presently.

Carbonic acid gas sometimes accumulates in wells in which pieces of timber or other organic matter are allowed to decay. Fire will not burn, nor can animals live, in an atmosphere consisting largely of $\mathrm{CO}_{2}$. This gas sometimes accumulates in silos from decay of the silage, and several cases are on record of deaths of farmers from this cause. If the top of the silo is open, or if there are side doors left open a little above the level of the silage, there is little or no danger from this source.

Combustion. Most chemical changes are accompanied by the production of heat. When carbon unites with oxygen to form $\mathrm{CO}_{2}$, and when hydrogen unites with oxygen to form $\mathrm{H}_{2} \mathrm{O}$, a great deal of heat is produced. The heat from an ordinary fire in which coal or wood is burned is due to the formation of $\mathrm{CO}_{2}$ and water by chemical union of the oxygen of the air and the carbon and hydrogen found in coal and woorl. This explains why a fire goes out unless air can get to it. Combustion, or burning, is thus due to chemical action in which great heat is produced.

In converting food to use in the body, the carbon and hydrogen of the food unite chemically with oxygen in the blood. The blood obtains its oxygen from the air in the lungs. There is thus a slow burning going on in the blood at all times. This is what keeps the body warm. The amount of oxygen taken in at the lungs is so small that the resulting combustion in the body does 
not go on rapidly. Hence, although a large amount of heat is produced, considering the small amount of

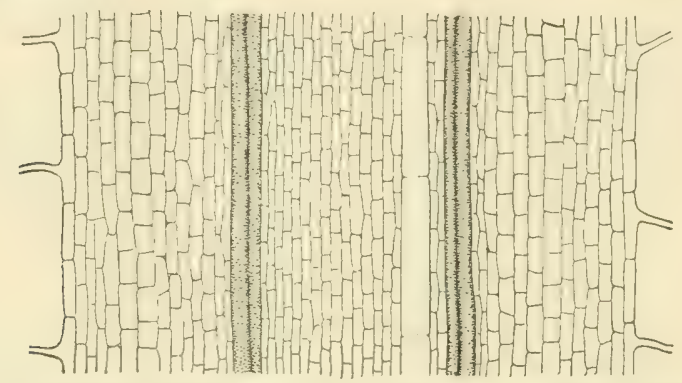

FIg. 70. Greatly magnified view of a thin slice cut lengthwise from a small corn root. The calls are elongated in the direction of the length of the root.

material burned, the resulting temperature is only moderate.

Internal structure of plants. When a very thin slice is cut from the body of a plant and examined under a high-power microscope, an internal structure like that seen in Figure 70 or $7 \mathrm{I}$ is found. Figure 70 represents a slice cut lengthwise, and Figure $7 \mathrm{I}$ one cut crosswise, from a small root of a corn plant. The body of the plant is thus seen not to be solid throughout. It contains, in fact, an immense number of small carities, separated by thin partitions. The cavities are called colls. The partitions are the cell walls. But these cavities are not empty in living plant material. Figure 72 (left end) shows what they contain. Just within the cell wall, and lying in contact with it, is a soft, jellylike material which scientists call cytoplasm. Since we shall have little use for this big word, it is not necessary to remember it longer than while reading this and a few 
later chapters. In plants, there are usually one or more drops of clear liquid cell sap lying in the cytoplasm. The green coloring matter in leaves is found in the cytoplasm of the cells of which leaves are built up. Grains of starch also are often found in this part of the cell.

Surrounded by the cytoplasm is the mucleus. This is by far the most important part of the cell. The structure of the nucleus is very com-

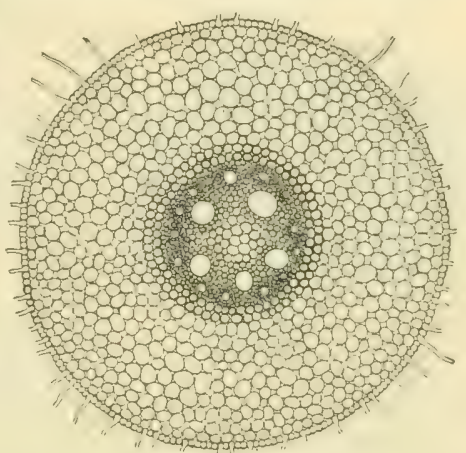

FIG. 7I. Greatly magnified view of thin slice cut crosswise from a small corn root. plex, and we cannot here consider it in detail. You will learn its structure if you study botany, or some other branch of biology. It is sufficient for our purpose to know that the real business part of the nucleus consists of a number of small bodies made up of a material called chromatin. This material is of the consistency of a rather thick jelly. It is the chromatin that has the power of converting food material into real body material. It thus presides over growth and nutrition. There is usually a thin membrane surrounding the nucleus and separating it from the cytoplasm, but at
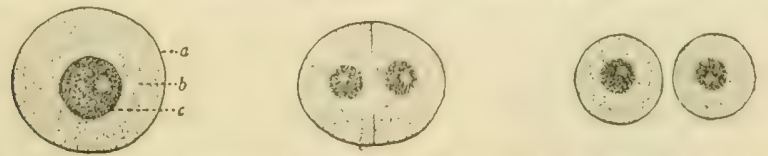

Fic. 72. Diagram of parts of a living cell. At left: $a$, cell wall; $b$, cytoplasm; $c$, nucleus. Center: a cell dividing. Right: two new cells formed from vil one. 
times this membrane disappears, and in some very lowly organisms it is not found at all. In fact, in some very

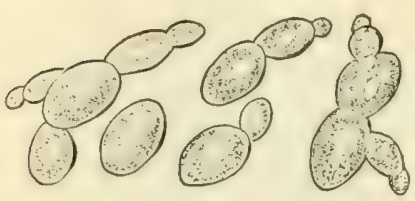

FIG. 73. Several individual yeast plants. All but one plant are in the act of producing new plants by "budding." simple forms of plant life the chromatin is scattered in small particles throughout the cytoplasm, but in all the higher plants it is collected into a true nucleus.

The term cell was applied above to the small cavities shown in Figures 70 and $7 \mathrm{I}$. Scientists more usually apply this term to the things contained in these cavities; that is, to the cytoplasm, nucleus, etc., including the surrounding walls. A typical cell thus consists of the cell wall, the nucleus, and the cytoplasm, with whatever bodies the cytoplasm may contain, such as chlorophyl grains, drops of cell sap, etc.

Number of cells in a living organism. The entire body of every plant or animal is built up of cells more or less like those we have been considering. These cells differ in size and shape in different kinds of plants and animals, and in different parts of the same plant or animal, but always they are very minute. The number of such cells in the entire body of a living organism is roughly proportional to the size of the body. We find everywhere little plants and animals so small that they are scarcely visible without the aid of a magnifying glass. These have relatively few cells in their bodies. But there are many kinds of both plants and animals that are too small to be seen by the unaided eye. Thousands of kinds of these are so small in size that even when 
full grown, they consist of a single cell. The numerous kinds of bacteria and yeasts are one-celled organisms.

Creatures exist consisting of all numbers of cells, from the one-celled yeasts, bacteria, etc., to creatures like the elephant, with bodies consisting of billions of cells.

Figure 73 shows some yeast plants, very much magnified. All but one of the individuals in this illustration happen to be in the process of producing new

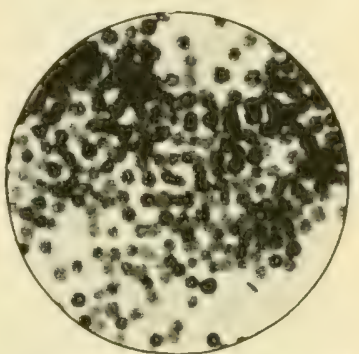

Journal of Agricullural Research

Fig. 74. Bacteria. cells, which in this plant are formed as "buds" from old ones. Teasts have another way also of producing new yeast plants, that we need not consider here.

Figures 74 and 75 show two kinds of bacteria, also greatly magnified. Though both yeasts and bacteria are one-celled organisms, yeast plants are much larger than bacteria.

How growth takes place. Every plant or animal, at the very beginning of its existence, consists of a single cell. The process by which they develop into large bodies consisting of a vast number of cells is illustrated in Figure 72. At the left of the figure is a single cell, with its cell wall, cytoplasm,

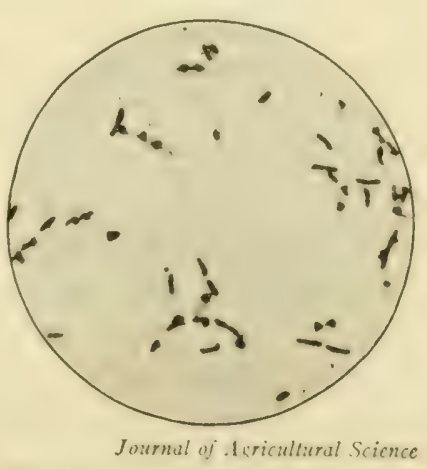

FIG. 75. Another kind of bacteria. 
and nucleus. When such a cell reaches its full growth, the nucleus first separates into two, as shown in the second section of the figure. Next a partition begins to form between the two new nuclei. When this partition is completed, we have two new cells where formerly there was but one. In the case of organisms that are to remain one-celled, the two new cells separate, as shown at the right of the figure. But if the individual is to develop into a many-celled organism, the two new cells stick together. When the new cells reach maturity, each of them divides again in the same way, and this process continues until the plant or animal has reacheci the full size which its hereditary characteristics call for.

Every organic being in the world is thus made up of cells, and every living cell was derived from another cell by essentially the process illustrated in Figure 72 . How did the first cell originate? The scientist who answers this question will rank among the greatest scientists of all time.

Conducting tissue. It has already been stated that plant roots absorb large quantities of water from the soil. Most of this water passes up through the roots and stem of the plant to the leaves, where it evaporates. In the body of the plant there are columns of long cells, the special purpose of which is to serve as channels for the upward passage of this water. These columns of cells are a part of the "conducting tissue" of the plant. The two dark-colored columns of cells in Figure 70 are conducting tissue. How the water gets into the roots of the plant, and how it passes through 
the cell walls in going from one cell to the next above, is told under the next heading.

\section{OSMOSIS}

Experiment. Obtain from some place where animals are butchered a fresh pig bladder. Fill it with water in which sufficient salt has been dissolved to make a strong brine. Then tie it securely with a cord strong enough to support its weight. Suspend it by this cord and carefully measure its circumference (the distance around it). Leave it suspended overnight in a vessel of water. (See Figure 76.) Next morning, if the bladder has not burst, take it out of the vessel and measure its circumference again. Has it increased in size?

In this experiment we have a thin wall which is more or

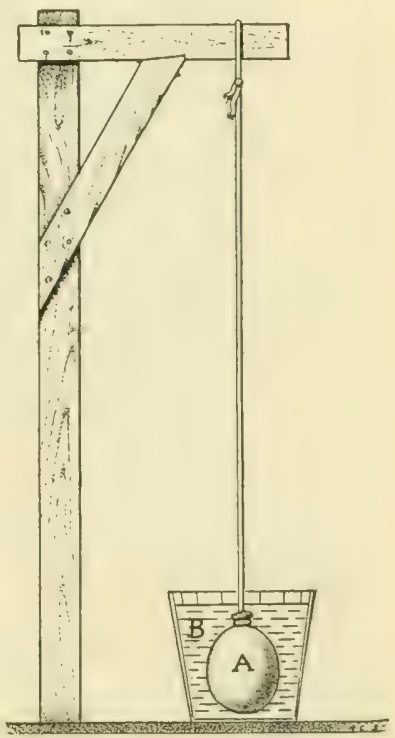

Fig. 76. Osmosis. A bladder filled with strong brine is placed in water. The water passes through the porous bladder wall and swells the bladder. less porous, though the pores are much too small to be seen, having on one side of it a dense liquid (brine) and on the other side a less dense one (water). Under such conditions the less dense of the two liquids flows through the wall into the denser liquid. Some of the latter also may flow through the wall, but not so much of it. This flow of a less dense liquid through a porous membrane into a denser one is called osmosis. This is the method by which plant roots absorb water from the 
soil, and by which water passes from cell to cell on its way from the roots up to the leaves. The sap in the root hairs is denser than the water in the soil. The sap in the cells in the upper part of the plant is denser than that in the lower part. Hence the water flows into the root hairs, and from cell to cell in the roots, till it enters certain conducting channels, up which it flows to the leaves. There it passes into the leaf cells, and again from cell to cell till it reaches all parts of the leaf and finally passes off as vapor into the air.

It is by this same process of osmosis that the food we eat, after being dissolved in the digestive juices in the stomach and intestines, gets into the veins, and is thus carried to all parts of the body. Osmosis is the most important process in nature. All life is directly dependent on it.

\section{HOW PLANTS DRINK}

Root hairs. Root hairs occur only near the tip of young, growing rootlets (Fig. 77). They live only a short while (a few weeks, perhaps), but new ones form farther on along the rootlet as it grows. Figure 78 shows the structure of a root hair. It also

FIG. 77. Root hairs. These occur only near the tips of growing rootlets. Their function is to absorb water from the soil.

shows the relation of root hairs to the other cells of the root. They are simply extensions out into the soil from the surface cells of the root. Inside their thin, delicate walls, or of those of the cells to which they are attached, there are a nucleus and cyto- 


\section{How Plants Live}

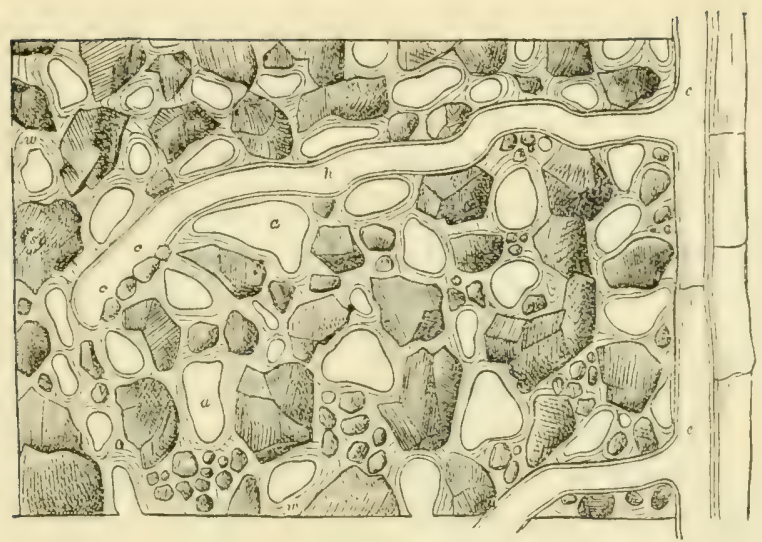

Yearbook, U. S. Dept. of Agric., 1894

FIG. 7S. Relation of root hair to soil grains: $e$, surface cell of the rootlet; $h$, root hair; $c c$, intimate contact of root hair and soil grains; $a a$, air spaces in the suil. Nute the water surrounding the air spaces and covering all the soil grains.

plasm, as there are in any living cell. The root hairs come into the most intimate contact with the rock particles and the particles of organic matter in the soil, as shown in Figure 78.

Office of root hairs. These slender projections from the surface cells of the growing rootlet have just one purpose. Their business is to absorb water from the soil, and along with it the soluble plant food materials contained in this water. Soil water enters the root hairs by the process of osmosis, as has already been stated. The plant food materials dissolved in this water enter along with the water.

The amount of water thus taken up from the soil by growing plants is very great. As before stated, it amounts to from 300 to $\$ 00$ pounds of water for every 
pound of growth made by the plant, not counting the water in the plant. The reason why so much water is necessary lies in the fact that the amount of plant food material dissolved in the soil water is exceedingly small, and it is necessary to take in enough water to obtain all the food material of this kind required by the growing plant.

Uses of water in the plant. The first service which water renders to plants is to bring into the plant all those kinds of plant food materials required from the soil. Water, with the aid of carbonic acid gas dissolved in it, dissolves several substances from the rock particles and the decaying organic matter of the soil. Once inside the plant, water serves as the vehicle for the transportation of plant food from one part of the plant to another. In plants that are not woody the walls of many of the cells are very thin and delicate. Were it not for the water in these cells, their walls would collapse. Water thus gives rigidity (stiffness) to the tender green plant.

By far the greater portion of the water that enters the roots of a growing plant is evaporated at its leaves. A smaller portion remains in the cells of the plant to give them rigidity. A still smaller portion enters into chemical combination with the carbon obtained from the air and the plant food materials obtained from the soil, and thus goes toward building up the various substances of which the plant consists. Water used in this latter manner loses its identity as water; that is, in these new combinations it is no longer water, the hydrogen and oxygen of which it is composed being combined differently from what they are in water. 


\section{How Plants Live}

Amount of water in plants. From 60 to 90 per cent of the weight of ordinary green growing plants, not including woody plants, consists of water. This is in addition to the hydrogen and oxygen taken from water and used in building up other substances. When new corn is ripe enough to husk, the grain contains about 25 per cent of water - enough to cause the corn to spoil if not housed in a well-ventilated storage room. When dried out until it contains only about I $_{2}$ to I $_{5}$ per cent of water, it is then dry enough to keep without danger of spoiling. Freshly cured hay may contain as much as 20 or 25 per cent of moisture, but is liable to spoil with more than about i5 per cent. Hay, grain, etc., are considered well dried with ro to I 2 per cent of moisture in them. In very dry regions hay and grain sometimes become so dry they have only 3 or 4 per cent of moisture. When as dry as this, they are very brittle.

Dry matter. By heating organic substances to a sufficiently high temperature (about 2 I 2 to 230 degrees) for several hours, practically all the water in them can be driven off. The material that remains is called " dry matter." Dry matter is sometimes referred to as "water-free" material. The percentage of water in several crop products is given in the preceding paragraph. Subtracting these percentages from roo gives the percentage of dry matter in the products.

\section{HOW PLANTS BREATHE}

Animals have special breathing organs, the lungs. This is because air cannot readily pass into the borly 
through the skin. When the air gets into the lungs, the oxygen of the air passes by osmosis through the thin walls of the blood vessels and enters the blood, where it is carried to all parts of the body. Chemical reactions take place between this oxygen and the food materials already in the blood. Thus a slow kind of burning takes place, and this furnishes the heat and energy required by the body.

Plants, unlike animals, have numerous openings in their outer covering through which air can enter and $\mathrm{CO}_{2}$ gas formed in the plant can pass out. Hence they do not require special breathing organs like the lungs of animals. In fact, lungs would be of little value to them without veins and arteries filled with blood driven by a heart to carry the dissolved oxygen in the blood all over the body. Oxygen absorbed through the pores of the outer covering unites with carbon in the growing parts of the plant, forming $\mathrm{CO}_{2}$, which passes out at the pores where the oxygen entered. Plants thus respire just as animals do, but the mechanism by which respiration is accomplished is different.

The $\mathrm{CO}_{2}$ absorbed by the green portions of living plants, mentioned under the next heading, has nothing to do with respiration. It is food material, not breath.

\section{HOW PLANTS FEED}

How their food materials are obtained. Plants obtain their food materials in two entirely different ways. First, their leaves and other green parts absorb carbonic acid gas $\left(\mathrm{CO}_{2}\right)$ from the air. The carbon thus obtained constitutes by far the greater portion of the 
dry matter of plants. In fact, the hydrogen and oxygen obtained from water and the carbon obtained from $\mathrm{CO}_{2}$ gas together make up almost the entire dry matter of plants except the portion left as ashes when plant materials are burned.

The other source of plant food materials consists of the substances dissolved in the water which plants absorb from the soil.

A difference between plants and animals. Animals get all their carbon from such foods as starch, sugar, and other carbon-containing substances eaten. They can make no use of the $\mathrm{CO}_{2}$ of the air. Among plants, it is only those that obtain food from living organisms on which they are parasitic, or from dead organic matter, that get their carbon as animals do. Other plants get all their carbon from the $\mathrm{CO}_{2}$ of the air.

Office of green coloring matter in plants. As already stated, the green color of leaves and young shoots is due to a substance called chlorophyl, a word derived from two Greek words meaning "green " and "leaf." This green substance is the most important single substance in the world. If it should suddenly disappear, all animals, and most plants, would die of starvation. Yet it is not a food for either plants or animals. Why, then, is it so important?

In carbonic acid gas $\left(\mathrm{CO}_{2}\right)$ the carbon is chemically combined with oxygen. In this condition carbon is utterly useless to both plants and animals. When $\mathrm{CO}_{2}$ is absorbed by the leaves of plants, its molecules come in contact with those of chlorophyl. Water also is present in the cells with the chlorophyl. When 
water, chlorophyl, and carbonic acid gas are brought together in the dark, nothing happens. But when these three substances are brought together in strong sunlight, a series of chemical reactions begins which results finally in the formation of starch, sugar, or other substances which serve as food for the growing parts of the plant. The process by which these substances are formed is called photosynthesis, from two Greek words meaning "light" and "putting together." The substances thus formed consist entirely of carbon, hydrogen, and oxygen. The carbon comes from the carbonic acid gas, and the hydrogen and oxygen from water. In weaker light the process of photosynthesis goes on less vigorously. Plants continue to grow at night as long as the products of photosynthesis formed during the day hold out, but they stop when these substances have all been used up. Crops grow less in cloudy than in bright, sunshiny weather, because in cloudy weather the process of photosynthesis goes forward very slowly. Hence little food is manufactured.

On a bright, sunny day leaves may gain as much as 30 per cent in weight from the starch formed in them. At night this starch disappears. The juices of the plant slowly convert it into a kind of sugar, which dissolves, and is then carried in the sap to all parts of the plant, where it is used in forming the many substances found in plants. To form some of these substances the starch (or sugar) must unite with the food materials brought in water from the soil.

Mineral food materials obtained from the soil. The water which plant roots absorb from the soil contains in 
solution many substances. These substances are mostly compounds (not elementary substances). But we are not here concerned with the compounds themselves; our interest lies in the chemical elements of which these compounds consist. One of these elements is nitrogen, which will be considered later. Several of them are not used by the plant as food, and we need not consider them further. They merely accumulate in the cells of the plant. The remaining six constitute what is called the mineral food material of plants. The names and chemical symbols of these six elements are:

$\begin{array}{llll}\text { Potassium } & \mathrm{K} \text { (Latin, kalium) } & \text { Phosphorus } & \mathrm{P} \\ \text { Calcium } & \mathrm{Ca} & \text { Sulfur } & \mathrm{S} \\ \text { Magnesium } & \mathrm{Mg} & & \\ \text { Iron } & \mathrm{Fe} \text { (Latin, ferrum) } & & \end{array}$

The four elements in the first column, when uncombined with other elements, are metals. The other two are non-metals. Iron and sulfur are familiar in their elementary form. The others unite so readily with oxygen and various other elements that they are never found in nature as elements, though chemists know how to separate them from their combinations and thus obtain them in their elementary form.

Sources of mineral plant food elements. These mineral plant food elements occur in various compounds found in the rock particles of the soil. When water has carbonic acid gas dissolved in it, as soil water always has, it can dissolve out considerable quantities of these mineral substances from the soil particles. In soils poor in humus, plants must depend very largely on this means of obtaining mineral food materials. But when 
plenty of decaying organic matter is present, the soil water dissolves mineral matter out of this. Mineral matter thus obtained is just what the plant needs, for it is the material used by preceding generations of plants. The importance of keeping the soil well supplied with decaying organic matter is thus clearly evident. It supplies a large amount of mineral matter of just the kinds needed by the growing crop. The great value of organic matter in the soil is perhaps the most important single lesson the farmer has to learn from the science of agriculture.

Nitrogen. All plants contain some nitrogen in their make-up. When not combined with other elements nitrogen is a gas, the molecular symbol of which is $\mathrm{N}_{2}$. As already stated, four fifths of the atmosphere consists of this gas, and this is the original source from which all the nitrogen in plant and animal substances comes. There is an ample supply of it. But in its elementary form nitrogen is useless as a food material for animals and for most kinds of plants. Fortunately there are some kinds of plants that can use it. We shall learn about them presently. The life of all other plants and of all animals is largely dependent on the activities of these plants that are able to take the free nitrogen of the air and build it into their bodies, and when they die leave the nitrogen in combinations that are useful to other plants. Animals get their nitrogen from these other plants.

Combined nitrogen in nature. When lightning flashes, a very small quantity of atmospheric nitrogen is caused to unite chemically with oxygen, forming nitrous oxid 
gas. This gas has a peculiar odor that is noticeable about electric machines, and may sometimes be observed for a few moments when a flash of lightning strikes near by. At the same time a small quantity of ammonia gas $\left(\mathrm{NH}_{3}\right)$ is formed, the hydrogen being obtained 'from water vapor in the air.

Both these gases are soluble in water. Hence rain washes them down into the soil. There certain bacteria convert them into nitrates. In nitrates $\mathrm{N}$ is always combined with oxygen in the proportion shown in the formula $\mathrm{NO}_{3}$. But the attractions of the atoms in this combination are not all satisfied; hence there is no substance with this formula. The $\mathrm{NO}_{3}$ must have something to unite with. The element calcium, found in lime, limestone, etc., serves well for this purpose. With $\mathrm{NO}_{3}$ it forms calcium nitrate, $\mathrm{Ca}\left(\mathrm{NO}_{3}\right)_{2}$. Or the $\mathrm{NO}_{3}$ may unite with potassium, forming potassium nitrate, $\mathrm{KNO}_{3}$; or with sodium, forming sodium nitrate, $\mathrm{NaNO}_{3}$. These nitrates are all soluble in water, and plants can use the nitrogen in any of them.

Sodium nitrate occurs in large quantities in the soil of certain localities in Chili, from which it is remored and sold as a fertilizer under the name "Chili saltpeter." Potassium nitrate, which is the true saltpeter, occurs in small quantities in several places, but nowhere in paying amounts. The nitrates in these deposits are believed to have originated from organic materials containing nitrogen. They occur only in very dry regions. They are so soluble in water that they would be washed out of the soil in regions where much rain falls. 
Nitrogen-fixing bacteria. By far the most important supply of nitrogen in a form useful to ordinary plants

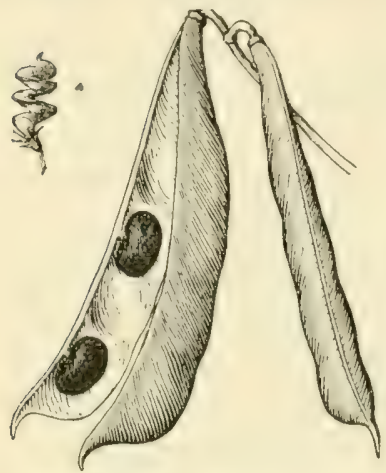

Fig. 70. Seed pod of a legume (j)ea pod). Alfalfa seed pod in upper left-hand corner. The structure of the two kinds of pods is the same, except that the alfalfa pod is twisted. is due to the work of certain kinds of very small organisms found in the soil. These little beings belong to a great group of organisms known as bacteria.

There are two (possibly more) very different kinds of these bacteria that can take in the free (uncombined) nitrogen of the air and build it into their substance. They thus manufacture nitrogen compounds that ordinary plants can use as food. These little plants (bacteria) are absolutely indispensable to the farmer. They are among the best friends he has in nature. The two distinct kinds are treated below.

Legume bacteria. There is a large and important family of plants known as legumes. Peas, beans, clover, alfalfa, and retches all belong to this family. They all have this characteristic in common, that their seeds are borne in a pod which consists of two "valves," or halves which split apart more or less readily. The pea pod is a good example (Fig. 79). Most of the plants of this family, including all those named above, have the so-called butterfly-shaped flowers, of which the pea blossom is a good example (Fig. 8o).

This entire family of plants have the remarkable 
characteristic of harboring in their roots a little parasite that is not only not harmful to them, but is highly useful. This parasite is nothing more or less than one of the two kinds of bacteria that are known to be able to use free nitrogen. Their natural home is in the soil. But when a legume seedling throws out root hairs into the soil, if the proper variety of this kind of bacteria is present they break through the walls of the root hairs and thus gain entrance into the roots of the plant. There they grow and multiply. At the point where they lodge a kind of wart, or gall, forms on the root. These are the "tubercles" found on the roots of all legumes when grown on a soil containing the

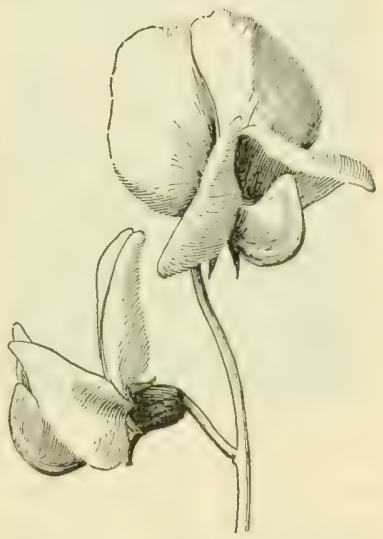

Fig. 8o. Blossom of a legume (pea blossom). The upper petal is the "banner," the two middle ones are the "wings," while the two lower petals are united along their lower edge to form the "keel," so called from its resemblance to the keel of a boat. The pistil and stamens are closed in the keel.

proper variety of bacteria (Fig. 8I). The student should examine the roots of all kinds of legumes for these tubercles. Generally speaking, they are about as large as the seeds of the plant on which they grow.

Though all these legume bacteria are very similar, and all belong to one group, they are not exactly alike. As a rule, those that grow best in the roots of one kind of legume will grow only poorly or not at all in those of another kind, though there are some exceptions to 


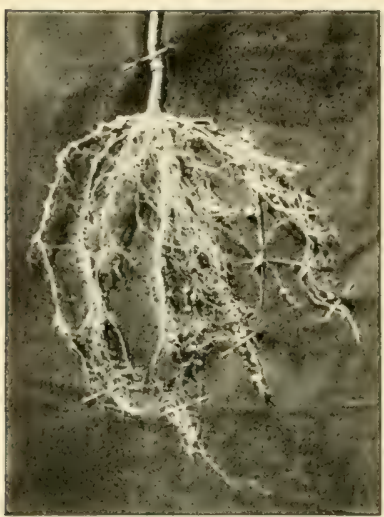

Office of Farm Manasement (G. A. Billings)

FIG. \&1. Tubercles on the roots of a soy bean plant. These are caused by the presence in the root of the bacteria that assimilate nitrogen from the air.

this statement. The bacteria of sweet clover, for instance, will grow readily in the roots of alfalfa.

Soil inoculation. When we sow any kind of legume, we should be sure that the soil of the field contains the kind of bacteria which that particular legume needs. If it does not, the crop will not thrive. Unless we are sure they are present we must add them to the soil, or to the seed before sowing. This addition of bacteria to the soil or to the seed is called inoculation. It may be accomplished in several ways. Common practice is to add to each acre a few hundred pounds of dirt from a field known to be inoculated, because it has recently produced a healthy crop of the legume in question. Farmers learned the value of this practice long before they knew its reason. Pure cultures of the proper bacteria may also be applied to the seed.

How legumes and these bacteria exchange labor. The reason the bacteria enter the roots of the legumes is because they like the particular brand of starch they find there. Since they have a great abundance of $\mathrm{N}$ available to them in the soil air, they manufacture a great abundance of nitrogen compounds, - more in fact than they need. The legumes tolerate these in- 
truders, and furnish them starch, because they can get nitrogen compounds from them.

Other nitrogen-fixing organisms. At least one other kind of bacteria can fix atmospheric nitrogen. (By "fixing" nitrogen is meant combining it chemically with other elements.) They live in the soil, but they have never formed the habit of invading the roots of plants. They live partly on soluble organic matter. When well fed, as they are in soil rich in humus, they fix considerable quantities of nitrogen and leave it in a form available to crops. We do not know much about these very useful bacteria. They were discovered only a few years ago. They may prove to be even more important as a source of combined nitrogen than we now suspect. There are also certain fungi that have the power of fixing atmospheric nitrogen. Not much is known about them.

Organic nitrogen. While all the nitrogen now in plants and animals came originally from the air by the ways outlined above, growing crops get a great deal of their nitrogen from the decaying organic matter in the soil. This is especially true if the soil is rich in organic matter. The roots, stems, and leaves of legumes, because of the ease with which they get nitrogen compounds from the bacteria in their roots, become very rich in this element. The roots of a leguminous crop decaying in the soil furnish much nitrogen to the succeeding crop. If the land is greatly in need of nitrogen, it sometimes pays to plow under a legume crop to enrich the soil in this important element. Legumes can grow in a soil having little or no nitrogen in it, provided 
they are properly inoculated, but other crops cannot do this. We must supply nitrogen to them in some way. It sometimes pays to use a little nitrogen fertilizer, even on a legume, to furnish nitrogen to the young plants before they become thoroughly inoculated. If not inoculated, they need nitrogen even more than do other crops.

How nitrogen is supplied to crops. Nitrogen may be supplied to crops in a form available to them by applying manure, which is usually rich in nitrogen, by growing legumes, especially by turning under leguminous crops, by adding nitrate fertilizers, or by adding to the soil any kind of organic matter that may serve as food for nitrogen-fixing bacteria.

\section{SUMMARY}

The various chemical elements required by plants, with the sources from which obtained, are as follows:

From the air :

Carbon, from $\mathrm{CO}_{2}$ in the air, absorbed by the leaves and other green parts of the plant.

Nitrogen, directly or indirectly, entirely from the nitrogen of the air; directly from the air by certain bacteria; by legumes, from certain kinds of bacteria, which originally obtained it from the air; by other plants, and to some extent by legumes, from decaying organic matter in the soil, from fertilizers, or from nitrogen compounds brought down by rain, and taken in, mostly in the form of nitrates, in solution in water obtained from the soil. All from the air originally.

Oxygen, directly from the air; used in breathing, and returned to the air in $\mathrm{CO}_{2}$. Absorbed by all growing parts of the plant. 


\section{From water :}

Taken in as water by root hairs in the soil. Some of this water is decomposed in the plant, and the hydrogen and oxygen of Hydrogen which it consists are used in building up Oxygen various compounds constituting a part of the dry matter of plants. Some of the water remains in the plant cells as water. By far the greater portion of the water absorbed from the soil evaporates at the leaves.

From the soil :

Potassium

Calcium

Magnesium

Iron

Taken in in solution in the soil water. Obtained from rock particles, from decaying organic matter, or from fertilizers. All from the rock particles of the soil originally.

\section{Things to Observe}

Winter annuals. In the fall or early winter, or at any time during the winter when the ground is bare, look in fields and by roadsides for the rosettes of young leaves of which the above-ground parts of winter annuals consist at that time.

Root hairs. Dig out young growing plants carefully and observe the numerous fine hairlike threads projecting from the roots near their tips. Root hairs occur near the tips of nearly all growing roots. Their business is to absorb water and plant food materials from the soil.

Legumes. Study the structure of the flowers and seed pods of all the leguminous plants arailable, such as peas, beans, cowpeas, alfalfa, clover, sweet clover, etc. Note how the seeds are arranged in the pod. Compare with other seed pods. 


\section{Farm Science}

Root tubercles. Carefully dig up all kinds of leguminous plants during their growing period and note the tubercles on their roots. These are due to the presence of nitrogen-fixing bacteria in the roots.

\section{Experiment}

Put a tablespoonful of common baking soda in a glass fruit jar and pour over it a half cupful of strong vinegar. The bubbles are due to the formation of $\mathrm{CO}_{2}$ gas, which soon fills the jar. Hold a blazing splinter in this gas inside the jar. Fire burns only when free oxygen is present; it cannot use the oxygen in $\mathrm{CO}_{2}$ gas. What happens to the fire in this experiment? 


\section{CHAPTER TEN}

\section{FERTILIZERS}

\section{Plant food elements likely to be deficient in the soil.}

Of the ten chemical elements required by growing plants nitrogen is by far the most likely to be deficient. It comes originally only from the air. But our common crops can use it only in certain chemical combinations, nitrates being most acceptable. Nitrates are quite soluble, and easily wash out of the soil when it rains. There are also bacteria of at least one kind that decompose nitrates if at the same time they can have plenty of substances like starch, sugar, and cellulose as food. Cellulose. like starch and sugar, is a compound of carbon, hydrogen, and oxygen. It is the substance of which the cell walls of plants are built. These substances are plentiful in straw and in fresh manure, especially where straw is used for bedding. By allowing the manure to ferment a few weeks, or by mixing stubble with the surface soil in the fall, we get rid of the materials these nitrate destroyers live on, and thus save nitrogen for the crop next year. A careless farmer can easily let his lands become badly deficient in nitrogen.

The only other elements that are not ordinarily abundant, either in air or water or the soil, are potassium and phosphorus.

Phosphorus is deficient in many soils. Its original source is a single kind of mincral, small grains of which occur in practically all soils, but sometimes in very small quantity. Although nitrogen is much more likely to be deficient than phosphorus, phosphorus fertilizers are more used than all other kinds together. This is be- 
cause nitrogen can be supplied in so many other ways, especially by growing legumes. Nitrogen fertilizers are also very expensive, while those containing phosphorus are the cheapest of all.

Potassium occurs in many kinds of rock particles in the soil, and is not often deficient in heavy soils such as clays, clay loams, silt loams, etc. But sandy soils and muck soils are quite generally deficient in this element, at least in forms available to plants. Potash fertilizers - that is, those containing potassium - are much more generally used on sandy and on muck soils than on heavier soils.

Calcium. While most soils contain plenty of calcium so far as the need of it as plant food is concerned, many soils need lime, which contains this element, for other reasons. (See page II3.) This element is therefore frequently applied to the soil in lime, ground limestone, or other compounds containing calcium.

Sulfur. Some recent experiments have given very good results from the use of sulfur, or some of its compounds, as a fertilizer. We do not yet know just what this means. Perhaps some soils are deficient in this element in available forms. This may possibly account in part for the fact that gypsum, or land plaster $\left(\mathrm{CaSO}_{4}\right)$, before it became too high priced, was widely used on farm land. It is often highly beneficial, but it has generally been supposed that this was due to the calcium it contains.

Magnesium has been used to a slight extent in fertilizers, but it is usually present in the soil in ample quantity. The remaining elements are always available 
to plants in superabundance, carbon in the $\mathrm{CO}_{2}$ of the air, hydrogen in water, oxygen in air and water, and iron in various compounds in the soil.

SOME COMMON FERTILIZER TERMS AND THEIR MEANING

Ammonia. Fertilizers containing nitrogen are often referred to as containing ammonia, a substance having the formula $\mathrm{NH}_{3}$. When we speak of the amount of "ammonia" a fertilizer contains, we simply mean the amount of ammonia that could be made from the nitrogen the fertilizer contains. This use of the term "ammonia "arose from the fact that ammonium sulfate, $\left(\mathrm{NH}_{4}\right)_{2} \mathrm{SO}_{4}$, and ammonium chlorid, $\mathrm{NH}_{4} \mathrm{Cl}$, are frequently used as fertilizers, for the nitrogen they contain.

Guano. In many parts of the world sea birds nest on cliffs facing the sea. Their manure collects in large quantities at the base of these cliffs. It is called "guano" (pronounced gwano-a as in "arm "), a Peruvian word meaning manure. This material was formerly much used as a fertilizer, being obtained mostly from the coast of Peru and from certain islands in the Pacific Ocean. The supply is now exhausted. In some localities, where it was once the only fertilizer used, all fertilizers are now called guano, but more especially those containing nitrogen.

Phosphate, acid phosphate, phosphoric acid, floats. The common source of fertilizers containing phosphorus is a soft rock found in large quantities in certain localities along the South Atlantic coast of the United States, in parts of Tennessee, and to some extent elsewhere. This 
rock contains a considerable quantity of a compound known as calcium phosphate. It also contains varying. quantities of limestone. Floats are simply this rock ground up into a fine powder. The rock itself is usually referred to as phosphate rock. When the ground-up rock is mixed with sulfuric acid, a reaction occurs producing, among other things, a phosphorus compound more or less soluble in water, thus making the phosphorus "available." In this form the material is called acid phosphate. This is the most widely used of all fertilizers containing phosphorus.

The term "phosphate" is loosely used to mean any fertilizer containing phosphorus, but its proper use is limited to compounds containing only the combination $\mathrm{PO}_{4}$. Thus, calcium phosphate is $\mathrm{Ca}_{3}\left(\mathrm{PO}_{4}\right)_{2}$.

When fertilizers first came into use (about a hundred years ago), the name "phosphoric acid" was at that time used for the substance whose formula is $\mathrm{P}_{2} \mathrm{O}_{5}$. It is now applied to a different substance, but the old usage has continued in the fertilizer trade. When we speak of the amount of phosphoric acid a fertilizer contains, we merely mean the amount of $\mathrm{P}_{2} \mathrm{O}_{5}$ that could be made from the phosphorus present.

Potash. Real potash has the formula $\mathrm{K}_{2} \mathrm{O}$, but any fertilizer containing the element potassium is called a potash fertilizer. It is common practice in stating the composition of fertilizers to give, not the amount of potassium present, but the amount of potash that could be made from this potassium.

Fertilizer formulas. In many parts of the country it is the common practice to use fertilizers containing all 
three of the elements: nitrogen $(\mathrm{N})$, phosphorus (P), and potassium $(\mathbf{K})$. Such a fertilizer is called a complete fertiliser, because it contains all the chemical elements ordinarily used as fertilizers. In stating the composition of a complete fertilizer, use is made of formulas such as $2 \delta 3,4$ io 6 , etc. The first of these formulas means that the fertilizer contains 2 per cent of nitrogen, enough phosphorus to make $\delta$ per cent of phosphoric acid $\left(\mathrm{P}_{2} \mathrm{O}_{5}\right)$, and enough potassium to make 3 per cent of potash $\left(\mathrm{K}_{2} \mathrm{O}\right)$; or, loosely, 2 per cent of nitrogen, 8 per cent of phosphoric acid, and 3 per cent of potash.

In some of the South Atlantic states the percentage of phosphoric acid is given first, that of nitrogen second, and that of potash third. This very confusing practice should be abandoned in favor of the more widely used form given above.

\section{SUBSTANCES USED AS FERTILIZERS}

\section{Nitrogen fertilizers.}

Sodium nitrate, or Chili saltpeter, about $\mathrm{I} 6$ per cent of $\mathrm{N}$

Ammonium sulfate

Cyanamid

Cottonseed meal

Dried blood

Ground fish

Tankage about 20 per cent of $\mathrm{N}$ about 16 per cent of $\mathrm{N}$ about 7 per cent of $\mathrm{N}$ 6 to 13 per cent of $\mathrm{N}$ about 8 per cent of $\mathrm{N}$ 4 to $\mathrm{I}_{2}$ per cent of $\mathrm{N}$

Leather and waste wool and hair are sometimes used in fertilizers by unscrupulous manufacturers, but the nitrogen in them is practically worthless because these substances decay so slowly. 


\section{Phosphate fertilizers.}

Acid phosphate I 2 to 18 per cent of $\mathrm{P}_{2} \mathrm{O}_{5}$

Phosphate rock (as floats)

South Carolina

Florida

Tennesse€

Bone meal, raw

Bone meal, steamed

Bone tankage

26 to 28 per cent of $\mathrm{P}_{2} \mathrm{O}_{5}$ I 8 to 40 per cent of $\mathrm{P}_{2} \mathrm{O}_{5}$ 30 to 35 per cent of $\mathrm{P}_{2} \mathrm{O}_{5}$

22 per cent of $\mathrm{P}_{2} \mathrm{O}_{5}$ (Also contains +.0 per cent of nitrogen.)

28 to 30 per cent of $\mathrm{P}_{2} \mathrm{O}_{5}$ (Also contains $\mathrm{I}_{5} 5$ per cent of nitrogen,)

7 to 9 per cent of $\mathrm{P}_{2} \mathrm{O}_{5}$

Thomas slag (basic siag) about 18 per cent of $\mathrm{P}_{2} \mathrm{O}_{5}$.

\section{Potash fertilizers.}

Kainit

Potassium chlorid

Potassium sulfate (high grade)

Wood ashes, unleached

Wood ashes, leached
I2 to 20 per cent of $\mathrm{K}_{2} \mathrm{O}$

50 per cent of $\mathrm{K}_{2} \mathrm{O}$

48 to 50 per cent of $\mathrm{K}_{2} \mathrm{O}$

5 to 6 ; also 2.0 per cent $\mathrm{P}_{2} \mathrm{O}_{5}$ and 29 per cent lime.

I ; also $\mathrm{I} .5$ per cent $\mathrm{P}_{2} \mathrm{O}_{5}$ and 28 to 29 per cent lime.

The first three of these substances are obtained from mines in Germany. The chlorin in the first two is injurious to tobacco, sugar beets, and potatoes. These two, as well as wood ashes, are injurious to seeds if they come in contact with them. They should be mixed with the soil sometime before the seeds are planted.

Kinds and amounts of fertilizers to use. The kinds and amounts of fertilizers to use in any given case depend on the character of the crop, the kind of soil and its previous treatment, the cost of fertilizing materials, and the value of the crop to be grown. Some suggestions were made on this subject in the part of this book devoted to soils, but it is evident that correct fertilizer 
practice is largely a matter to be worked out by the farmers in each locality. The subject is too complex and difficult for full treatment in an elementary work of this kind. There are many books devoted especially to soils and fertilizers, some of which the student is expected to study later in his course.

\section{Problem}

In what proportion should sodium nitrate ( 6 per cent N), acid phosphate ( $\mathrm{I}_{4}$ per cent $\mathrm{P}_{2} \mathrm{O}_{3}$ ), and kainit ( 20 per cent $\mathrm{K}_{2} \mathrm{O}$ ) be mixed to give a fertilizer containing 3 parts $\mathrm{N}, 8$ parts $\mathrm{P}_{2} \mathrm{O}_{5}$, and 5 parts $\mathrm{K}_{2} \mathrm{O}$ ?

HrNT. A ton of 16 per cent sodium nitrate contains $320 \mathrm{lbs}$. N.

A ton of 14 per cent acid phosphate contains $280 \mathrm{lbs} . \mathrm{P}_{2} \mathrm{O}_{5}$.

A ton of 20 per cent kainit contains 400 lbs. $\mathrm{K}_{2} \mathrm{O}$.

3 lbs. $\mathrm{N}_{2}$ are contained in $\frac{3}{3} \frac{}{2} 0$ ton of sodium nitrate.

8 lbs. $\mathrm{P}_{2} \mathrm{O}$ are contained in $\frac{2}{2} \frac{8}{80}$ ton of acid phosphate, etc. 


\section{CHAPTER ELEVEN}

\section{PLANT PROPAGATION}

Plant propagation means the production of new plants from old ones. Plants have several methods of producing offspring, and man has invented several other ways of multiplying certain of the plants that he grows. All these methods will be considered briefly here.

\section{PROPAGATION FROM SEED}

Most kinds of plants are propagated from seed. It is well worth our while to learn how seeds are produced.

Parts of a flower. While flowers differ greatly in their structure, there is a general pattern to which most kinds conform. This is shown in Figure 82, in which each part of a typical, complete flower is named. The outermost circle of leaves constitutes the calyx. The

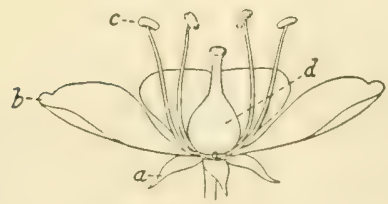

Fic. 82. Parts of a typical flower. a. sepals. These are usually green, like ordinary leaves. $b$, petals, usually white, red, blue, purple, or yellow. c, stamens, consisting of filament or stem, and anther. The anther contains the pollen. $d$, pistil, consisting of the ovary (enlarged basal portion), style (the slender neck), and stigma, usually at the top of the style. The ovary contains the ovules, which, fertilized by the pollen, develop into seeds. individual leaves of the calyx are called sepals. The sepals of most flowers are green in color like ordinary leaves. Their principal office is to protect the inner, more tender parts before the blossom opens. They form the outer layer of the flower bud. Just inside the circle of sepals is another circle of much modified leaves called petals. They are usually white, purple, red, blue, or yellow, though other colors 
occur. The petals taken together constitute the corolla. Their principal office is to attract insects. The reason for this will appear later. Many kinds of flowers have no petals. In some both petals and sepals are colored. In grasses, the petals and sepals are replaced by "glumes," which constitute the chaff when the seeds are threshed out. Figure $8_{3}$ shows the structure of a typical grass flower. Wheat and oats belong to the grass family. Examine their flowers and see if you can identify their parts as shown in the figure.

Inside the circle of petals is a row of slender, clublike organs called stamens. Since these are very important in the production of seed, we must

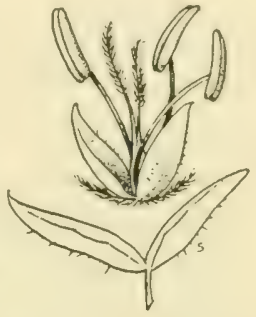

Fig. 83. Parts of a grass flower. Here the place of sepals and petals is taken by glumes, which are the chaff from threshed grain. Grass flowers usually have three stamens and a pistil simi. lar to those of ordinary flowers. study them closely. In preparing this lesson you will, of course, study many kinds of flowers for the purpose of identifying the parts here described.

A stamen consists of two parts, a stem, called the filament, and an enlargement at the end of the stem called the anther. The whole stamen is a much modified leaf. The filament is the stem and the anther the blade, or flat portion, of the leaf. When fully mature the anther splits open, usually at its two edges, and a very finegrained yellow powder falls out. This powder is extremely important; it is called pollcn. You may have noticed the yellow powder that gets on your clothes when going through a cornfield when the corn is in silk. 
This is the pollen of the corn plant. Look for pollen in all the flowers you find.

Lastly, in the center of the flower is the pistil. It stands there somewhat like a pestle in a mortar, which you can see in any drugstore. Its name is a modification of the Latin word for pestle. The pistil is the most. important part of the flower, because it later becomes the seed pod. Find the pistil in as many flowers as you can. Some flowers have more than one.

In examining flowers, especially in the fall of the year, you will find many kinds that will puzzle you, for they will appear not to be constructed on the pattern here described. One of the largest and most common families of flowering plants has its flowers bunched together in a head that looks very much like a single flower. This is the family to which the sunflower and the aster belong. Pick one of these flower heads to pieces and see if you can make out the individual flowers of which it consists.

The pistil ordinarily consists of three parts. The lower part, which is usually somewhat enlarged, and which will later contain the seeds, is the ovary. The slender neck extending upward from the ovary is the style. At the end of the style, or sometimes along the side of it, there is always an area over which there is no skin, or epidermis, although every other part of the plant has such a protective covering. This area with no skin to cover it is called the stigma, a Greek word meaning "wound."

The stigma in many kinds of flowers is on a knob at the top of the style. In some kinds the upper part of 
the style is branched. In the wheat flower it is much branched, presenting a beautiful feathery appearance. In the corn plant the threads of the silk are the styles. The stigma in this case occupies a narrow strip down the side of the style.

Structure of the ovary. Figure 84 shows an ovary split lengthwise to show its structure. Inside is a cavity in which are seen a number of small, round objects that are later to grow into seeds. They are the ovules. They are attached by short stalks to the walls of the ovary. Their number varies in different kinds of plants, some kinds having only one, while others have a large number in each ovary.

Fertilization of the ovules. It has already been stated that every living cell arose from a previously existing cell by a process known as cell division. The first step in cell division is the division of the nucleus. This division of the nucleus may occur in two ways. The chromatin of the nucleus con-

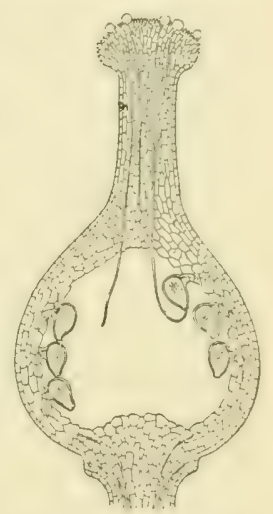

Fig. 84. An ovary split lengthwise to show the method of fertilization of the ovules. Pollen grains light on the stigma, and send their tubes down into the substance of the ovary. The tip of the tube enters an opening in the ovule, where the nucleus from the pollen tube unites with that of the germ cell in the ovary. This cell then develops into the embryo of the seed. sists of a number of very small but definite bodies. In ordinary cell division, each of these chromatin bodies divides, so that each of the new cells formed is supplied with its share of every chromatin body found in the old nucleus. 
The cells which are to take part in seed formation are called germ cells. In the production of germ cells, there occurs one cell division in which the chromatin bodies do not divide. Instead, half of them go into one of the new cells, the other half going into the other. A germ cell, therefore, has only half of a true nucleus.

Pollen grains are germ cells. There is also a germ cell in each ovule. An ovule cannot develop into a seed until its germ cell has been supplied with the half nucleus it lacks. It obtains this missing part of its nucleus from a pollen grain. The ingenious method by which this is accomplished is as follows:

At just the right time a sticky juice appears on the stigma. A pollen grain, falling on this, sticks fast, absorbs a portion of the juice, and begins to grow. It sends out a tiny thread much like a root hair, described in a previous chapter. This thread is the pollen tube. The half nucleus of the pollen grain passes down inside this tube, and is always found at or near the end of it.

As the pollen tube grows it works its way down into the substance of the ovary, just as a root hair threads its way through the soil. Finally the tip of it finds in an orule a small opening which is provided for this purpose (Fig. $S_{4}$ ). These pollen tubes are too small to be seen by the naked eye, but in the drawing they are enlarged to show their behavior. They do not always come out into the cavity of the ovary, as shown in the figure, but grow down in the walls till they reach the orules.

Now the germ cell of the ovule is situated just inside the opening which the pollen tube finds in the ovule. When the tube comes in contact with this cell, the end 
of the tube and the cell wall dissolve away at the point of contact, and the half nucleus of the pollen grain passes into the cell. The germ cell of the ovule is now provided with an entire nucleus, and is able to grow. This union of two half nuclei is called fertilization of the orule. Soon after fertilization occurs, the fertilized cell divides, thus becoming two cells. These grow rapidly to full size and divide again. This growth and division continue till a mature seed is produced.

A few kinds of plants produce seeds without this elaborate process of fertilization, but they need not concern us here.

One cannot help wondering why nature ever developed so complex a process for producing seeds, but this is a question which belongs to the science of plant physiology, and we cannot here enter upon its discussion.

Some common modifications of flowers. A peculiarity of the flowers of the sunflower family has already been mentioned (page I64). Very few kinds of flowers are as simple in structure as the ideal one shown in Figure 82. In peaches, plums, and cherries, the sepals, petals, and stamens are united at the base into a kind of cup. in the center of which stands the pistil, which later develops into the fruit. In the apple blossom the inside of this cup is grown to the ovary, so that all of the pistil that is visible is the branches of the style, with the stigmas at the end of them.

In "double" flowers, part or all of the stamens are changed into petals. In some kinds even the pistil is thus changed. Such flowers, of course, produce no seed, though if the pistil is unchanged they may produce seed 


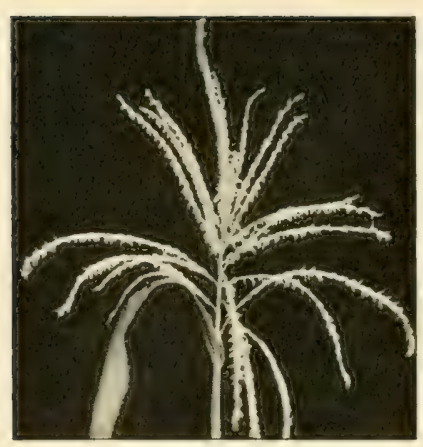

Corn Investigations, U. S. D. A.

Fig. 85. Tassel of a cornstalk, covered with flowers that bear only stamens, the pistils being aborted.

if pollen is brought from "single" flowers of the same species.

The corn plant bears flowers in two places, on the cob and on the tassel. The flowers on the tassel (Fig. 85 ) bear only stamens, as the pistils in these flowers are aborted. Those on the cob have pistils only, the stamens being aborted. The threads of the silk (Fig. 86) are the styles, and each thread has a long stigma running down one side of it. The pollen grains fall on these stigmas, and their tubes grow down in the substance of the silks to the ovaries at the bases of the silks. If the wind is blowing a great deal when the pollen is falling, the various ovules on a cob may be fertilized by pollen from many neighboring stalks. Ears of corn that grow on the side of the field from which the wind blows at this time may fail to receive pollen grains on some of their silks, and thus fail to fill out properly. Look for ears on the west side of a field of corn that have vacant spaces among their grains due to this cause. It is not always possible to find such ears, for the wind may not have been blowing much when the pollen was falling.

Self- and cross-fertilization. When an ovule is fertilized by pollen from the same plant that bears the ovule, it is said to be self-fertilized. When the pollen 
comes from another plant, the ovule is said to be cross-fertilized. Wheat and oats are generally selffertilized; corn and all kinds of fruits are quite generally cross-fertilized. Corn depends on the wind to carry pollen from one plant to another; fruits, and many other kinds of plants, depend on insects to do this. Some kinds of plants will not even produce seed unless they are crossfertilized. Others produce readily when self-fertilized. Some kinds of fruits require cross-fertilization, and

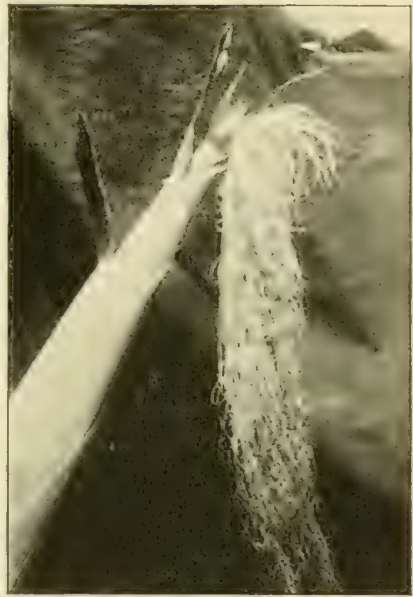

Corn Investigations, U.S. D. A.

FIg. S6. An ear of corn in silk. The strands of the silk are the styles of the flowers on the cob. The stigmas extend down the silles of the threads of the silk. The stamens in the flowers on this part do not develop. many kinds produce larger fruits if cross-fertilized.

We can now understand why so many flowers are bright colored and showy. The primary object of this showiness is to attract insects. Such flowers produce nectar in order to reward insects for visiting them and thus bringing them pollen from other flowers. It is not sufficient that the insect bring pollen from any kind of plant; it must be from the same kind of plant or from a nearly related kind. Hence insects have developed the instinct of visiting flowers of the same kind one after the other, rather than visiting any and all kinds promiscuously. It must not be supposed, how- 
ever, that every plant having brilliant flowers requires cross-fertilization, or is regularly cross-fertilized. Perhaps at some time in the past such flowers did require cross-fertilization, but many of them are now regularly self-fertilized.

Hybrids. When the pollen that fertilizes a given ovule comes from a plant which possesses different hereditary characters from those of the plant bearing the ovule, the resulting seed is said to be hybrid. The term cross-bred has about the same meaning, but is usually applied to cases in which the difference between the parents is not very great, while the term hybrid is used for cases in which it is more or less marked. But there is no sharp line of distinction in the use of the two terms.

Hybrid individuals do not ordinarily breed true to type ; that is, their offspring are usually not all like them, and not even like each other. Thus, if a bean having red seeds be crossed with one having white seeds, the resulting hybrids will have red seeds; but when these hybrid red seeds are planted, some of the plants that grow from them will have white seeds. You will learn the reason for this when you study biology.

Fruits are generally cross-fertilized, for which reason most of them are very complex hybrids, and when the seed is planted nearly every seed produces a different kind of fruit. This is the reason that fruits are generally propagated by some artificial method rather than from seed. These artificial methods will be discussed later.

Structure of seeds. Seeds usually have a thick outer and a thin inner coat. In some kinds the outer coat is hard and woody, as in the walnut. In others it is thin 
and not woody, as in the bean. The inner coat is usually thin and papery. In corn and wheat, and many other kinds of seeds, the two coats are firmly grown to the inner portion of the seed. In barley the outer husk is really not a part of the seed; it is a glume that adheres to the seed. It corresponds to a petal of ordinary flowers.

Study the structure of a number of different kinds of seeds. This can best be done by soaking the seeds in water till they are soft. Several kinds should be germinated in order to see what each part of the seed develops into as the young plant begins to grow. Study particularly a bean or pea as compared with a grain of corn. All seeds have more or less food stored in them for the use of the germinating plantlet till it has its own leaves and roots and is thus able to get its food from the air and the soil.

When the seed coats are removed from a bean or pea, what is left is nothing but a young bean or pea plant. The bulk of this little plant consists of the first two leaves of the vine, very much swollen with stored food, and not at all the shape of ordinary leaves. These make up the two "halves" of the seed. They are entirely sejarate from each other except at one end, where their stalks are attached to the very short stem. Lying between these two fat leaves is a pair of very small begimnings of leaves. When the bean seed sprouts, both the big fat seed leaves and the pair of tiny leaves between them come above ground and turn green. In the pea the first pair do not come above ground, for they are so misshapen that they would be of little use as real leaves. The little plant in a seed is called the cmbryo, or germ. 
In corn, as well as in wheat, oats, and many other kinds of seeds, part of the food is stored outside of the embryo, forming what is known as the endosperm. By soaking a grain of corn till it is soft, the germ, or embryo, may easily be separated from the endosperm.

Corn, wheat, oats, rye, and barley belong to the Grass Family. In this family of plants the embryo has one large leaf-rudiment, with a very small second one just visible about the middle of the large one. The beginning of the root also can be seen.

\section{OTHER NATURAL MEANS OF PROPAGATION}

The most common method of propagation in plants is, of course, from seeds. But many kinds of plants have other methods. The banana plant, for instance, has forgotten how to make seed, and is propagated entirely from sprouts that come up about the base of

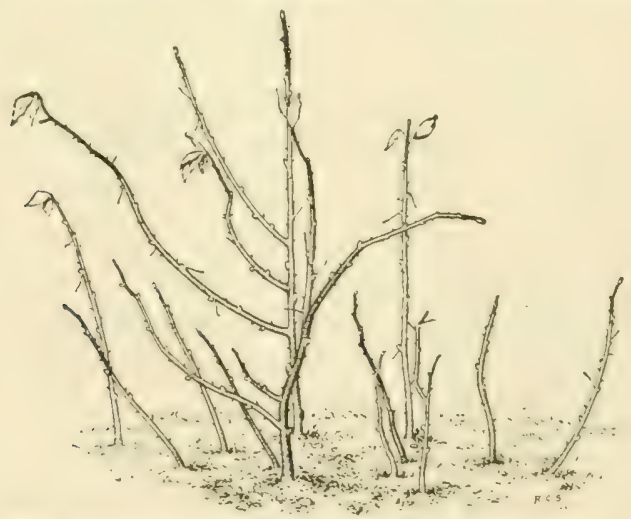

FIG. 87. Sprouts coming up from the roots of a rasplerry bush. When these are one year old, the old stalks are cut away, and the ensuing season the yearling sprouts bear fruit. 


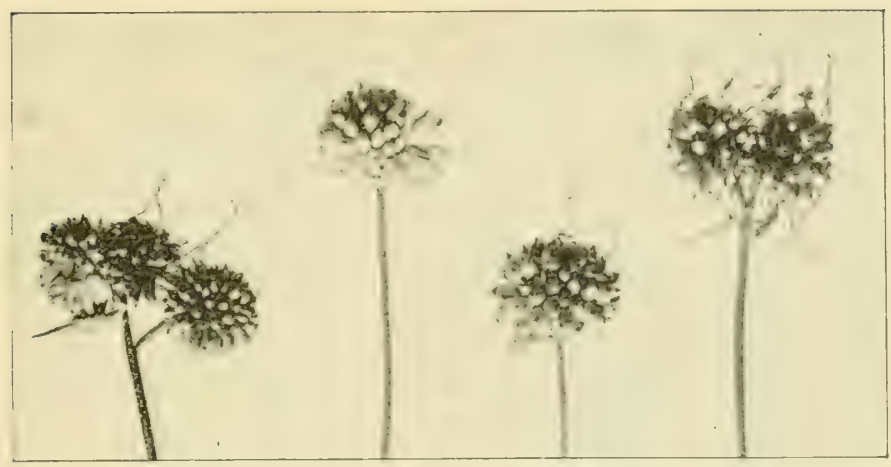

Ofice of Farm Management (J.S. Cates)

FiG. 88. The "sets" of wild garlic. They grow in place of flowers at the top of the stem. When mature they fall off, and soon take root and grow into new plants.

old plants. A brief discussion follows of methods of propagation other than from seeds.

Sprouts. Sprouts are new stems that arise from the underground parts of plants or from the main stem near or at its base. They are sometimes called suckers, though this latter term is also applied to branches of the main stem at any point where such branches are not desired. Thus, the tobacco plant produces suckers just above each leaf, which must be removed if a good quality of tobacco is to be grown.

Irish potato vines develop from sprouts that arise from the "eyes" of the tubers used as seed. These eyes are merely the buds on the tubers. By examining a potato it will be seen that the eyes are arranged according to a definite plan, just as the buds on trees are, though the plan of arrangement may be different.

Sweet potato vines develop from sprouts that arise 


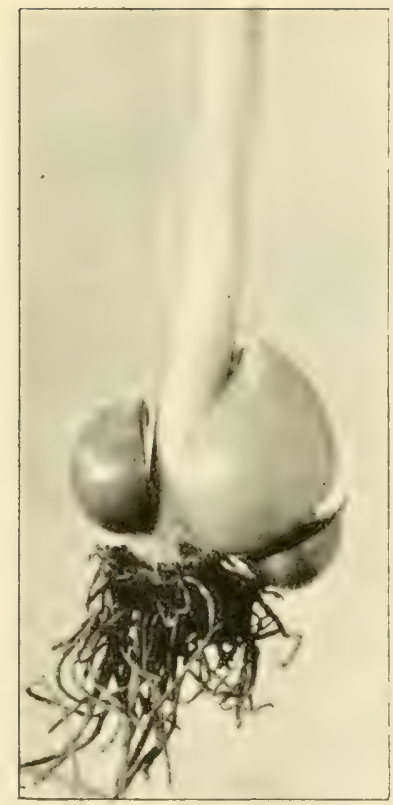

Office of Farm Management (J. S. Cates)

Fig. 89. Bulbs of wild garlic. They are contained in the old bulb of the previous year, the layers of which have been removed to show the newly formed bulbs. from the enlarged roots when these are buried in warm soil. In this case the sprouts may come from any point on the surface of the potato. This is true of all roots that produce sprouts.

Johnson grass and quack grass, which produce long underground stems, or rootstocks, send up sprouts from the buds found at the joints of the underground stems. This is the reason why these grasses are so hard to kill. They also produce seed abundantly.

Blackberries, raspberries, and gooseberries are often propagated from sprouts that come up about the base of the old stems (Fig. 87, page I 72 ).

Sets. In some kinds of onions part or all the flowers may be replaced by buds with thick, fleshy leares. These buds are called sets. Some varieties of onions are regularly propagated from sets. Wild garlic also produces sets (Fig. 88, page I73).

Bulbs. Onions and many other kinds of plants, especially of the lily family, produce bulbs. (See page I26.) Certain biennial plants, including onions, produce bulbs 
the first year from seed, but do not produce seed that year. If the bulbs are saved over and planted, the plants which grow from these bulbs produce seed again. Other bulb-producing plants form new bulbs at the base of the stems which grow from the old bulbs. The variety of onions known as "multipliers" does this. Wild garlic, a winter annual, also produces bulbs in this manner (Fig. S9), in addition to the sets which grow at the top of the stem.

Runners. The strawberry plant sends out runners, or vines which run along on the ground and take root at each joint (Fig. 90). When the roots at a joint become well established, a new plant arises from the bud at this joint. These new plants are dug up and set out as needed. Strawberries also produce seed, but they are not ordinarily used for planting, because the fruit of strawberry plants grown from seed will not usually be of the same kind as that of the plants which bore the seed. The reason for this is that practically all strawberries are hybrids. Many other plants reproduce by runners. Bermuda grass is an example.

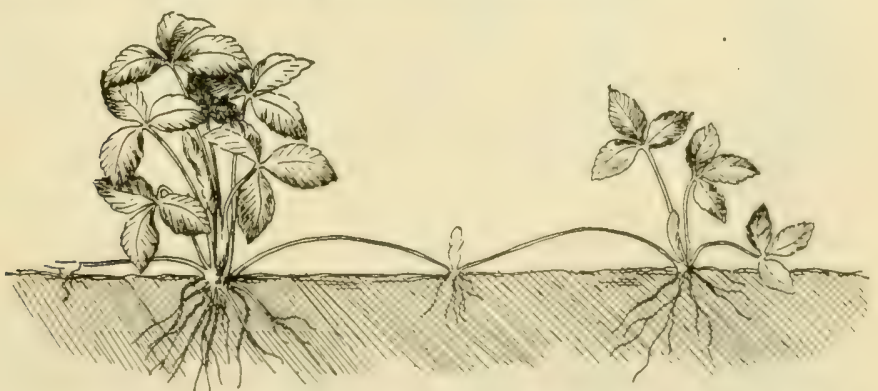

Horticultural Inicstigations, U.S. D. A.

Fig. 90. Runners of the strawberry plant. A new plant grows at each joint of the runner. The new plants are then dug up and set out where needed. 


\section{ARTIFICIAL MEANS OF PROPAGATION}

The means of propagation discussed above are those used naturally by plants. Man has also invented several means of obtaining new plants from old ones. All of these artificial means consist of cutting off part of the plant from which new plants are desired and then of inducing the cut-off part to grow. The various ways differ mainly in the methods used for insuring this growth.

Layering. We have seen how strawberry plants produce runners which take root at the joints and send up new plants from the buds at these joints. By bending down the branches of many kinds of plants till they are in contact with the soil, especially by covering a portion of the branch with soil, leaving the tip of the branch uncovered, the covered portion will throw out

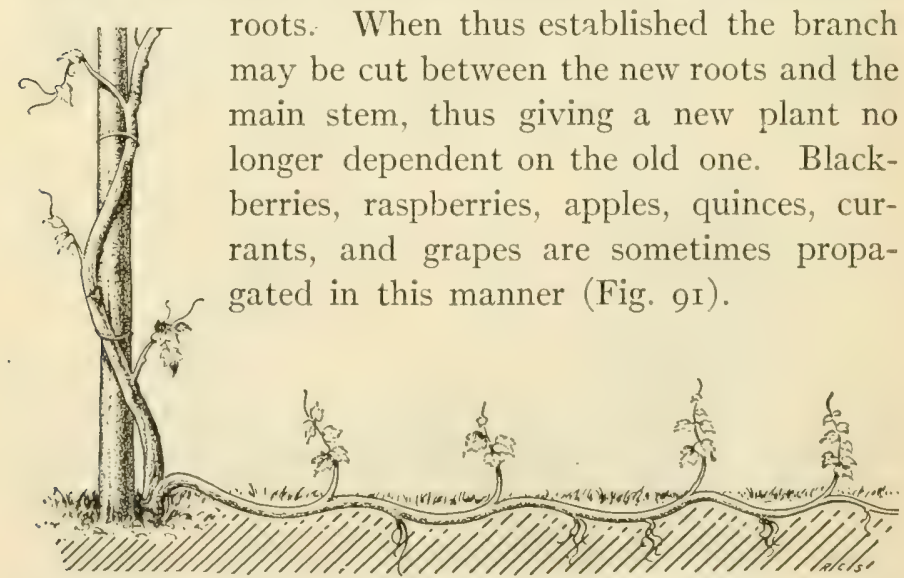

FIG. 9r. Layering as a means of obtaining new grapevines. The old vines are laid down and partially buried. New vines grow from the joints. 
Cuttings. Many kinds of plants can be propagated merely by cutting off a portion of a branch and sticking

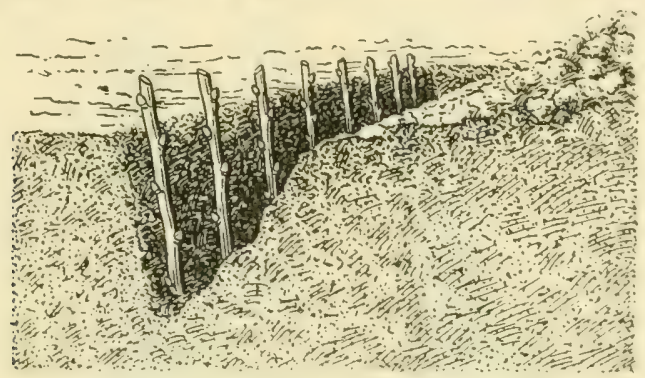

Morticallural Incestigations, U. S. D. .1.

FIG. 92. Grapevine cuttings being set in trenches. Roots grow from around the buds beneath the soil, while branches grow from the buds above ground.

it into the ground. Roots start from around the buds that are below the surface of the soil. The nutriment required to grow these roots comes from the sap of the cutting. Willows and poplars are easily propagated in this manner. Roses and grapes take root less readily, and some care must be used in getting their cuttings started. Leaves and branches grow from that portion of the cutting that is above ground. Figure 92 shows grape cuttings being set out in well-prepared soil. In some kinds of plants pieces of roots may be used for cuttings. In this case the cuttings should be completely buried.

After sweet potato slips (sprouts from the fleshy roots buried in warm earth) have been set out and begun to grow vigorously, the tips of the young vines may be cut off and set out. They readily take root. In the South, where the season is long, a large planting may in this way be made from a small beginning. 
Budding. Certain kinds of fruit trees are quite generally propagated by a process called budding. First,

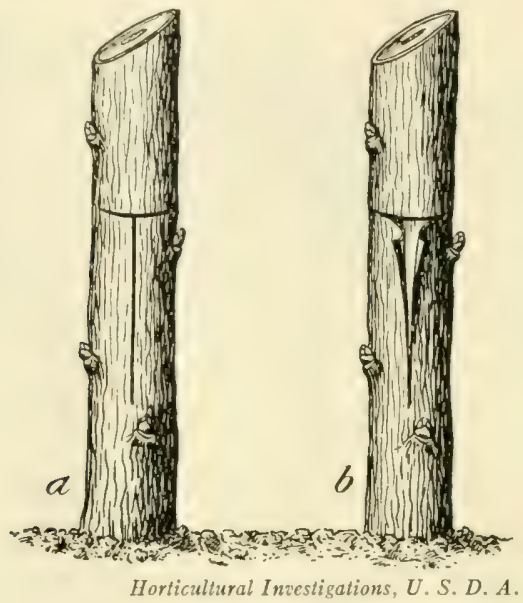

Fig. 03. The first two operations in budding. First, a horizontal cut is made in the bark of the stock. Second, a vertical cut is made, and the bark peeled back. The stock is now ready to receive the new bud.

seedling plants are grown, in nursery rows. During midsummer, when growth is most vigorous, buds are cut from the variety to be propagated and inserted into the seedling stem near its base. (See Figures 93 and 94.) If the bud takes, - that is, if it grows, - the seedling stem is cut off the next spring just above where the bud was inserted. The bud then grows into a new stem of the variety desired.

There are several methods of budding, but the principles are the same in all. In cutting the bud to be used, a portion of the bark around it is sliced off with the bud; also a very little of the wood under the bud. In one 
method, a horizontal cut is made in the bark of the seedling (Fig. 93), and a vertical slit is made downward

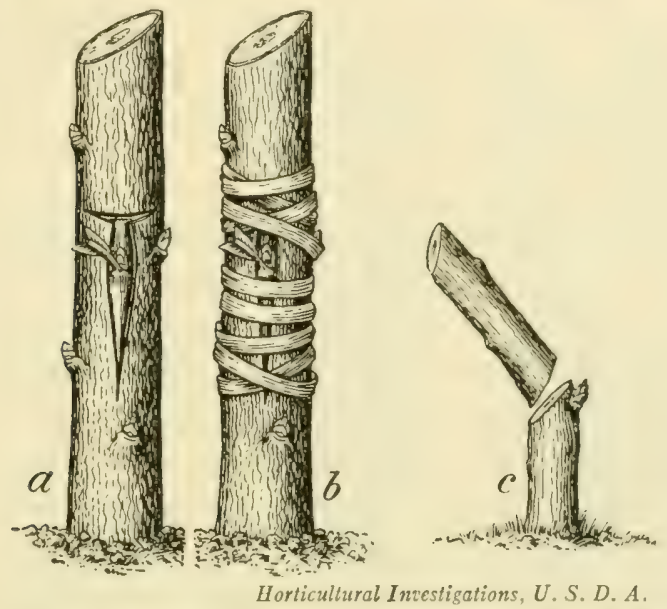

Fic. 94. Further operations in budding. The bud is cut from the scion, or bud stick (not shown here), and inserted under the bark of the stock, as shown. The bark is then pressed firmly on to the bud, and the stock is wrapped to keep the bark in position. After the bud "takes," the stock is cut away just above the bud.

from the center of this cut. The bark is then loosened from the wood as shown in the figure, and the bark attached to the bud is inserted under the bark of the seedling (Fig. 94). The bud bark is pushed down as far as possible without bruising it, and is then cut off at the top even with the horizontal cut, so that the freshly cut surface of the bud bark may rest directly against the freshly exposed wood of the seedling. The two flaps of seedling bark are then pressed down on the bud bark and firmly tied in position by some kind of wrapping material wound around the seedling stem at this point. 
In preparing the bud for this operation the leaf at the base of which the bud is situated is cut away, leaving just enough of the stem of the leaf to serve as a handle for the bud. After the bud begins to grow well, the wrapping material is removed.

Peaches, cherries, and plums are usually propagated by budding.

Grafting. Apples and pears are usually propagated by a process called grafting. Many other kinds of plants may be propagated in this manner. There are numerous ways of performing this operation, but the same principle is employed in all of them.

Grafting may be defined as the process of producing a new plant, the upper part of which is derived from one plant while the lower part is derived from another. In this broad sense budding is merely a form of grafting. The part which is to form the upper portion of the new plant is called the scion, while that which is to form the lower part is called the stock. The scion determines the kind of fruit the new plant is to produce. 'The stock may be of any kind that will produce a strong, vigorous root and that will unite readily with the scion.

Carefully scrape away the outer bark of a one-year-old branch of any common fruit tree. Between the wood and the bark will be found a thin layer of material known as the cambium layer. It is this cambium layer that brings back from the leaves the plant food manufactured there. In our common trees all growth of stem and bark takes place at the cambium layer. The fundamental principle to be obsered in making a graft is to bring the cambium layer of the scion in contact 
with that of the stock. If this is not done, the graft will not grow. The scion must, of course, be fastened firmly in place so that it will not move till the union of stock and scion is complete.

The scions to be used in grafting are usually obtained by cutting off small branches from the tree which it is desired to propagate. This is done when the tree is pruned; that is, when some of its limbs are cut off to give the others room to grow. The parts pruned away are saved for scions. Since pruning
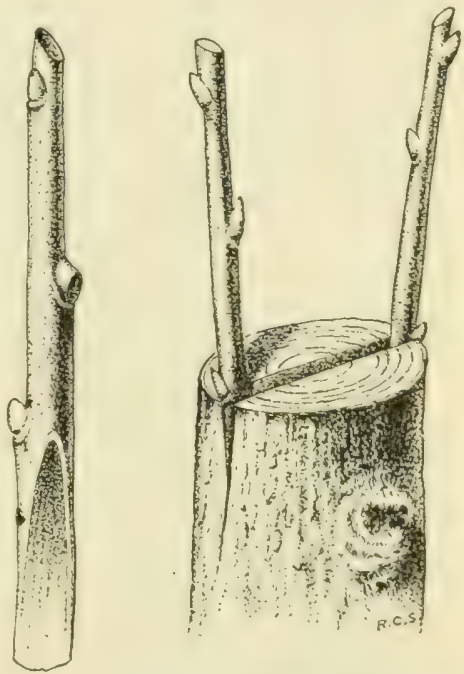

Fig. 95. Ordinary cleft graft and method of inserting it in the stock. is usually done when there are no leaves on the tree, the scions may be kept for some time before they are used if care is taken not to let them get too dry.

The common way of obtaining stocks for grafting is to grow a large number of seedlings. These may be dug up when winter comes and stored in a cellar with the roots in moist sand to prevent drying. The grafting is usually done just before time to set the seedlings out again in the spring.

In Figure 95 is shown a common method of performing the operation of grafting, by cutting off the stock 
squarely at a point a few inches above the root, and then splitting it back an inch or two. The lower end of the scion

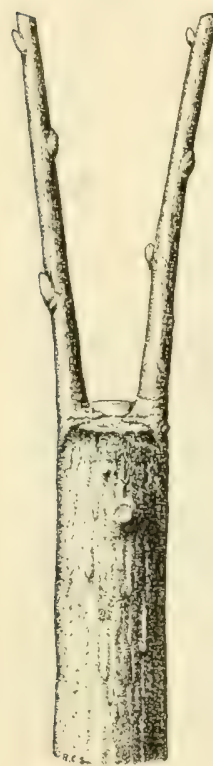

Fig. 96. Year-old grafts. is then trimmed to a wedge shape and inserted into the split in the stock as shown at the right in the figure. The important thing in putting the scion in place is to make sure that the cambium layer on one side of the scion is exactly opposite the cambium layer on one side of the stock. The union between stock and scion takes place between the two cambium layers, and it is useless to make a graft without bringing these two layers together.

As soon as the scion is in position, the wounded surfaces of both scion and stock, except where they are in contact with each other, are covered with a specially prepared grafting wax, which is put on thick enough to form a support for the scion, and keep it from working loose before the union is complete. The wax is then covered with some soft wrapping material which is securely tied in place. A fibrous material sold under the name "raffia" is commonly used for this wrapping. The grafting wax not only helps to hold the scion in place but also tends to protect the exposed wood of stock and scion from the destructive action of the bacteria, molds, and fungi that cause decay.

If the stock is large enough, two scions may be inserted in it. If both grow, one of them may later be removed. 
Figure 96 shows two scions on one stock a year after the grafting was done. The wrapping and all the wax except that in the crevices have been removed.

Several other ways of attaching scion to stock are given in books on fruit culture.

Influence of stock on scion. While stock and scion unite, and become to all intents and purposes a single plant, neither of them changes its nature in the least. The fruit produced by the new plant will be exactly the same kind as that produced by the tree from which the scion was taken; except in the rare cases where "bud sports" occur

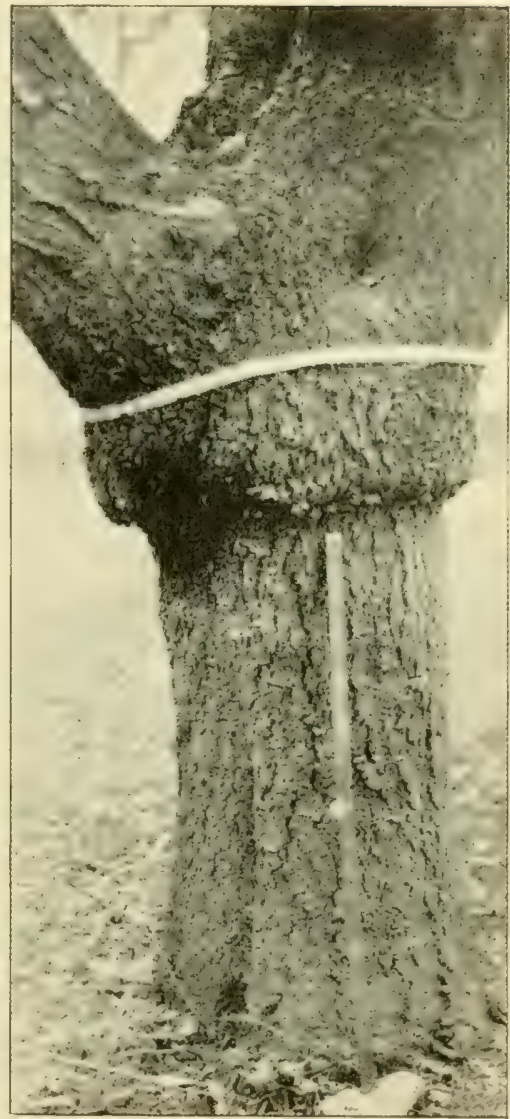

Journal of Heredily

Fic. 97. Almond grafted on plum stock.

The scion has outgrown the stock. (see below), or the still rarer cases in which a bud arises from the line of union between stock and scion, and thus consists partly of stock and partly of scion. If a 
sprout comes from below the point of union, it will be entirely of the kind represented by the stock, and will show no influence of the scion.

Stock and scion should be of kinds that grow at about the same rate; otherwise results like those shown in Figure 97 may occur. In this case an almond was grafted on to a plum. The almond scion has outgrown the plum stock.

Relation of offspring to parent plant. When we cut off part of a plant and cause it to grow into a new plant, the new individual is really a part of its parent, and has exactly the same hereditary qualities as the parent. Even bulbs and sets are actually part of the mother plant and have the same qualities. It is only when new individuals are produced from seed that we have a chance to obtain a new combination of hereditary qualities, for the seed has, or may have, two parents, each of which transmits to the offspring a part of its own qualities. A cutting has but one parent, and it retains all the qualities of that parent. A seedling may be quite different from either of its parents.

Bud sports. While buds generally have exactly the qualities of the plant which produced them, occasionally a bud is produced that differs somewhat from the branch that bears it, but this is a rare occurrence. A branch that bears fruit not exactly like that of the rest of the tree is called a bud sport. The cause of such sports is not known. Nectarines originate as bud sports on peach trees. They may be said to be peaches without any fuzz on them. 


\section{Plant Propagation}

\section{Things to Observe}

After studying the descriptions of flowers in the text, examine all manner of flowers and see if you can identify the parts.

Observe in cornfields that occasionally a tassel has grains on it; that is, instead of producing flowers having only stamens, a tassel sometimes produces flowers having pistils. This is especially likely to occur on the tassel of suckers that come up from the base of the cornstalk. Did you ever observe that corn suckers more in wet years than in dry ones?

Examine mature and immature seed pods and note the number of compartments in them, and how the seeds are attached to the inner surface of the pod.

Soak seeds of beans, peas, melons, corn, wheat, etc., in water till they are soft, or even till they begin to sprout, and then carefully examine the structure of these seeds. See if you can identify the parts mentioned in the text. Plant some of all these kinds of seeds and note what part of the plant it is that comes up first. It is not the same in all cases. 


\section{CHAPTER TWELVE}

\section{WEEDS}

CERTAIN kinds of weeds are very hard to combat. Satisfactory means have not yet been found for handling

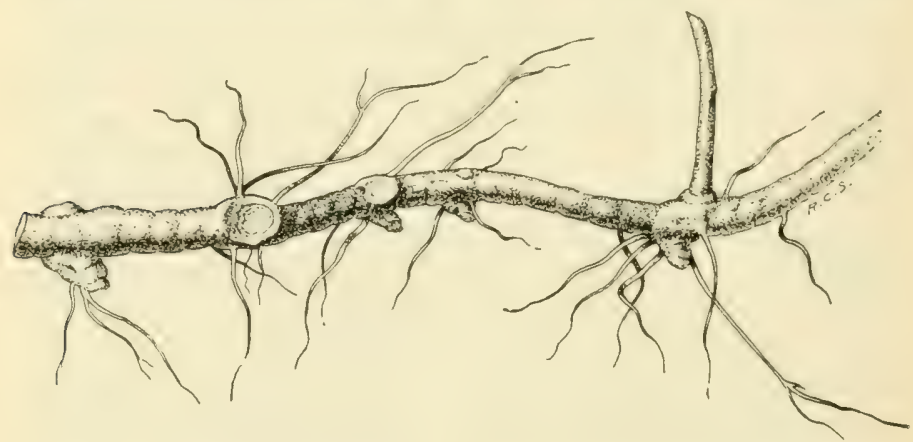

FIG. 98. Rootstock a year old. It sends up new sprouts, then dies at the end of the season.

all of them, but methods are now known by which some of the worst weeds can be controlled. The more important of these methods are given below.

Rootstock-producing weeds. The worst weeds of the rootstock-producing type are Johnson grass of the South (called "Means" grass" in South Carolina) and quack grass of the North. The rootstocks, or underground stems with a bud at each joint (Fig. 98), grow from buds in the crown of the plant, just a little below the surface of the ground. They begin their growth just about the time the plant begins to blossom (Fig. 99). If the plants are left undisturbed for a few weeks after this the rootstocks grow vigorously, sometimes reaching lengths of ro feet or more. If the soil is loose and fertile, they may go quite deep ; but if it is compact, the root- 
stocks grow along not far below the surface. If the above-ground portion of the plant be cut away just as it begins to blossom, the energy of the plant must again be used for making new leaves and above-ground stems, so that the growth of the rootstocks is seriously checked. In the long summers of the South, Johnson grass may be cut twice for hay without danger of rootstock formation, if the cutting is clone while the plants are in bloom. In the short summers of the North, quack grass can be cut only once. Immediately after the first cutting of quack grass or the second cutting of Johnson grass, the ground should be plowed as shallow as possible to insure getting below the crowns (meeting place of stems and roots) of all the plants. After this the land should be harrowed occasionally to prevent any further growth from the

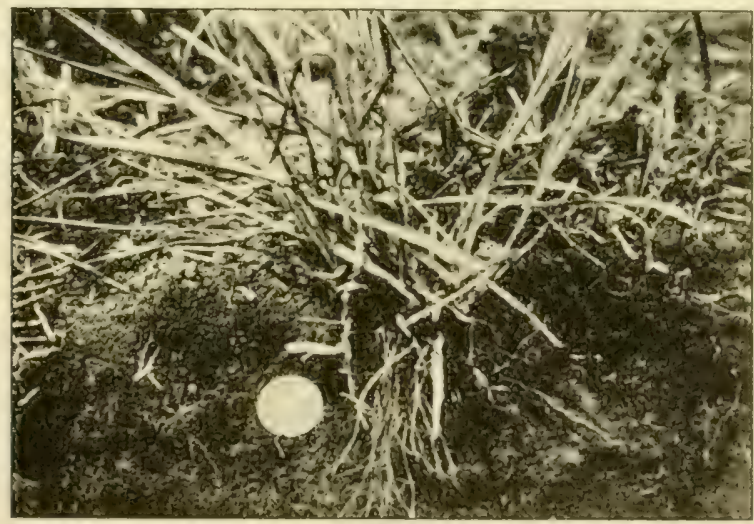

Office of Farm Managenent ( $J$. S. Cates)

FIG. 99. Rootstocks of Johnson grass just beginning their growth, which they do about the time the plant blossoms. One rootstock is seen just above the coin, another about $2 \frac{1}{2}$ inches to the right (pointing downward). 
crowns till cold weather begins. This kills the crowns completely, and also prevents the formation of rootstocks. There is thus left in the ground only the old rootstocks formed the previous year. But these all die a natural death at the end of the season. Hence the land will be clean the next year.

In plowing to kill the crowns of the old plants, it is of the utmost importance not to plow too deep. If the crowns are buried deep, they will start new growth and thus live over till the next season.

Running weeds. The commonest weed that produces runners, or stems that run along on the surface of the ground, taking root at the joints, is the Bermuda grass of the South. It is a very fine pasture grass, but is troublesome in cultivated crops. By plowing Bermuda grass land shallow in midsummer, and then preventing all growth of the grass till cold weather, it can be completely killed out. In this case also deep plowing must be avoided, for the runners, when buried sufficiently deep, go right on growing. The idea is to cut the grass loose from the soil beneath and then prevent it from getting its roots into the soil again. Other running weeds may be handled in the same manner.

Wild garlic. The common wild garlic, often called "wild onion," of the Atlantic Coast states has spread in recent years as far west as the Mississippi River. It gives trouble especially in pastures, because cows are very fond of the leaves, while the oil in them gives the milk and its products a very disagreeable flavor. It is also a very bad weed in wheatfields. It grows about as high as the wheat, ripens about the same time, and 
the "sets" at the top of the garlic stems are about the same size and weight as grains of wheat (Fig. 88, page I73). They are thus harvested with the wheat and get into the threshed grain, where they play havoc with its milling qualities.

The sets at the top of the stalk fall to the ground in midsummer and germinate late in the fall or early next spring. The plant also has a large soft-shelled bulb at the base of the stem, which germinates early in the fall and makes considerable growth before winter, and begins growth again very early in the spring. Around this central, soft-shelled bulb (Fig. 89, page I74) are a number of smaller hard-shelled ones, that germinate any time from late fall to the middle of the next summer - except, of course, in the dead of winter.

A single deep plowing late in the fall buries the sets so deep they cannot grow, and destroys the plants which have already started from the large bulbs. If, then, a cultivated crop is grown the next year and the plants coming from the hard-shelled bulbs are killed by cultivation, the land is then clean of this pest.

Some dairymen claim that if cows are allowed to pasture on wild garlic only in the forenoon, after the morning milking, the milk will not be flavored. During the several hours after they are taken off the pasture and before they are milked again, the oil which cause's the bad flavor is evaporated through the lungs and blown out in the breath. It takes about four hours for this to occur completely. Other farmers claim that even with the precaution above mentioned the milk is still tainted. 
Winter annuals. Many weeds are winter anıuals. They come up in the fall and form a rosette of leaves (Fig. 69, page I29), sending up their seed stems the next year. These are killed by spring plowing. In fall-sown grain they may be held in check by harrowing the grain a few times in the spring. If the grain is sown a bit thick to allow for this, the yield is not reduced thereby. The wild mustard infesting the wheatfields of the Pacific Northwest is one of the worst weeds of this class. It is easily controlled by harrowing.

Summer-fallowing for weeds. When the system of cropping is such that no summer-tilled crops are included, farmers sometimes cultivate the bare land all summer once every few years as a means of getting rid of weeds. This is an expensive method, but where land is cheap, it sometimes pays.

Smothering crops. Some weeds are best controlled by growing a crop like millet, sorghum, etc., that grows thick and rank and thus shades small weeds, greatly weakening them. The so-called nut grass of the South produces a number of tuberlike roots which may live for several years and then send up sprouts. About the only way to control it is to grow an occasional smothering crop.

Cultivated crops in the rotation. If the succession of crops that follow one after the other on a field includes an occasional cultivated crop, - that is, if every field on the farm is devoted to a summer-tilled crop once every few years, -- the cultivation of this crop gives a chance to kill most of the ordinary annual weeds except those that germinate very late in the season and then make seed 


\section{Weeds}

before frost. If these late weeds bother, it is sometimes possible to exterminate them by pasturing sheep for a while in the cultivated crop unless the crop would thereby be injured. Corn can be pastured in this way for a short time before the ears are ripe. After that the sheep soon begin to break down the stalks to get at the ears.

\section{Class Exercise}

Make a list of all serious weed pests of ycur community. Find how they are propagated, and how long they live. Some weeds, like Canada thistle and one kind of morning glory, have fleshy roots that send up stems much the same as rootstocks do. Ascertain from local farmers the best methods of fighting each kind of weed that is abundant locally. 


\section{CHAPTER THIRTEEN}

\section{INSECTS}

Number. About 400,000 kinds of insects have been described and given names by scientists. This is probably less than half the kinds actually in existence.

Relation to human welfare. Only two kinds of insects have been domesticated. These are the silkmorm, from the cocoons of which silk is obtained, and bees, which furnish honey and beeswax.

Many other kinds of insects are highly useful. The cochineal insect is used for producing a red coloring matter. An extract from the bodies of another kind is used in medicine for producing blisters in the treatment of certain kinds of inflammation. Thousands of insects are useful because they destroy other insects. Thus the green bug, or aphis, is held in check by the young of the ladybug. which feeds on them. Many insects lay their eggs in the backs of caterpillars and other soft-bodied forms. These hatch into young which devour the substance of their host's body. The idea that insects very generally have insect enemies is well expressed in the little verse that says:

\footnotetext{
'Tis said that every kind of fleas

Has other fleas to bite 'em;

These smaller fleas have other fleas,

And so ad infinitum.
}

If it were not for the fact that certain kinds of insects are held in check by parasites or other insects that kill them, the earth would not be a fit abode for man. If every grasshopper hatched were to live out a normal life and produce its full quota of offspring, in a few years 
grasshoppers would become so numerous that they would eat up every green thing that grows.

Insects also perform a useful office in carrying the pollen of one flower to the stigmas of others. But there is a danger here, for they carry also the germs of disease from one plant to another. Pear blight may be spread in this manner.

Many human diseases are transferred from one person to another, by insects. Certain disease germs require for their full development that they must live part of the time in one animal and part of the time in another. Thus the germs which cause the ordinary form of malaria can live only a limited time in human blood. In order to continue normal reproduction they must be transferred to the body of a certain kind of mosquito. After living there for a time they must again be brought back into human blood. This kindly office is performed by the particular kind of mosquito subject to this disease. He sucks up human blood containing the germs, and when the germs have given him a siege of chills and fever he then transfers them back to the first human being he bites. It is obvious that the bite of this mosquito is harmless unless the mosquito is itself sick with the disease.

Yellow fever is similarly carried by another kind of mosquito. The last time this disease broke out in New Orleans, it was stopped by the extermination of the mosquitoes that carry it. In the absence of these insects the disease cannot pass from one person to another. The same is true of malaria. The cattle fever so destructive in the South is carried from one animal to another by a certain kind of tick. This tick 


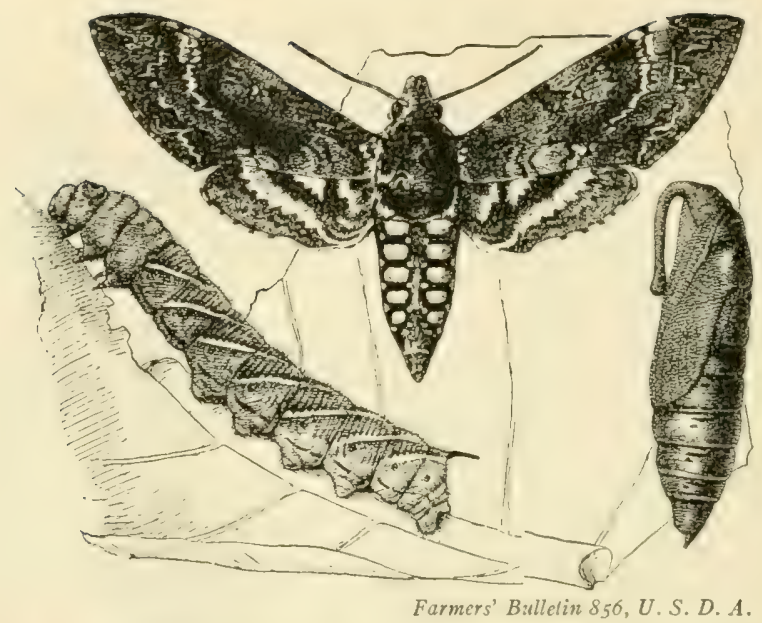

Fig. 100. Life stages of a moth. First stage, egg (not shown in the figure); second, citerpillar, lower left; third, pupa, lower right (this is the chrysalis stage); fourth, mature insect, upper.

is now being eradicated, and in sections where this has been accomplished the fever has disappeared.

Typhoid fever is carried by the common house fly, but in another way. The germs of this disease occur in large numbers in the excrement of typhoid patients. When this is not properly handled, flies, which lay their eggs in such filth, get the germs on their feet and then carry them into the house and spread them over everything on which they light. In this way human food becomes contaminated, and those eating such food get the disease. Flies themselves do not have typhoid.

Typhus fever is carried by a certain kind of body louse which is itself subject to the disease. The elimination of these lice stops the spread of typhus. 


\section{Insects}

\section{Stages of insect life.}

Many kinds of insects pass through four different stages before they complete their life cycle. First is the egg, which hatches into what is ordinarily called a worm (Fig. IOO). Examples of these are caterpillars, tobacco worms, and maggots. This worm

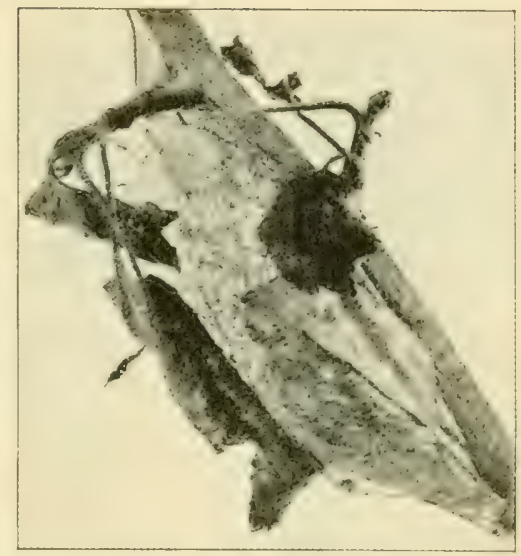

Home Yalare Slaty Course, Comll Lumeraty stage is called the larva of the insect.

Caterpillars are the larval stage of moths or butterflies. The tobacco worm is the larra of a large moth. Maggots are the larvæ of flies. Larvæ feed ravenously and grow rapidly. When full grown they shed their skin and are then found to be very different from what they were before. This new stage is the pupa. Pupæ neither eat nor grow. Finally the pupa sheds its skin and the full-grown insect comes out. By imprisoning worms in cages with an abundance of their favorite food, the progress through these various stages may be observed. Most of the harm done by insects is done in the larval stage. Many kinds of larvæ spin cocoons about themselves, and change into pupx. and these change into full-grown insects, within these cocoons. Silk is made from the cocoons of silkworms. Cocoons of some common insects are shown in Figures IOI and IO2. 


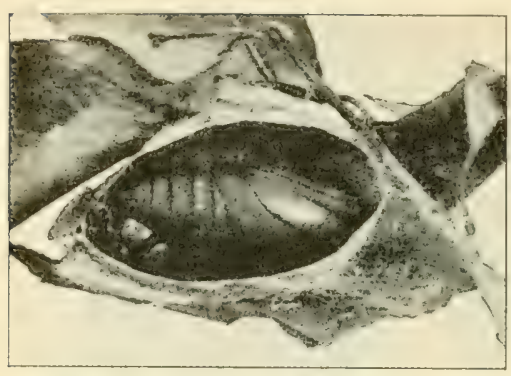

Home Vuture Study Course, Concll University

FIG. 102. Cocoon of another species of butterfly. The side is cut away to show the pupa within.

more like the full-grown insect. The squashbug develops in a similar manner. Its life stages are shown in Figure I03.

Methods of feeding. Many kinds of insects have mouth parts adapted to chewing their food, and they eat leaves or other parts of plants. When their eating is done in the open (not inside the plant), such insects may be killed by putting poison on their food. Paris green, a compound of arsenic, and lead arsenate are used for this purpose.

Other kinds of insects live only on the juices of plants. They are provided with mouth parts that enable them to pierce the skin of the plant and suck out the plant juices. Poisons are useless in fighting these kinds. They may be killed by the use of caustic substances that attack their bodies, or by cily substances that spread over them and stop their breathing pores. The green bug, scale insects (Fig. I04), and the squashbug are examples of this type. 


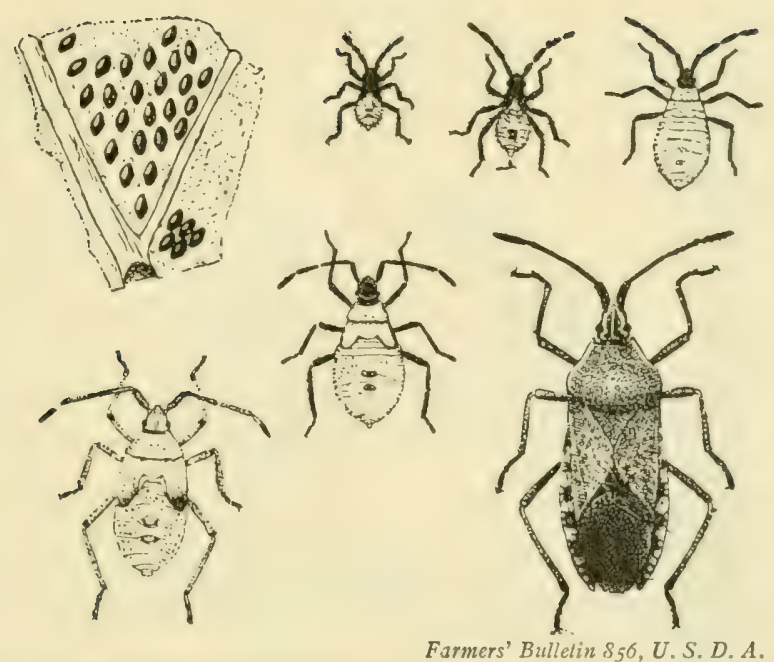

Fig. I03. The stages of development of a squashbug, from erg (left upper corner) to mature insect. The insect sheds its skin in passing from one stage to the next.

Fumigation. Some insects are best combated by the use of poisonous gases. Orange growers sometimes cover their trees with cloth and then set free under the cloth a very poisonous gas called hydrocyanic acid. This kills the insects on the trees. Sulphureted hydrogen gas $\left(\mathrm{H}_{2} \mathrm{~S}\right)$ is frequently used for killing insects in stored seeds. Formalin gas also is used for this purpose.

Why the boll weevil is hard to fight. Before cotton blossoms, the old boll weerils that have survived the winter eat the young leaves just forming at the end of the stem and its branches. Even if poison is spread over the plants, the new growth that is continually coming out will have no poison on it, and the insect 


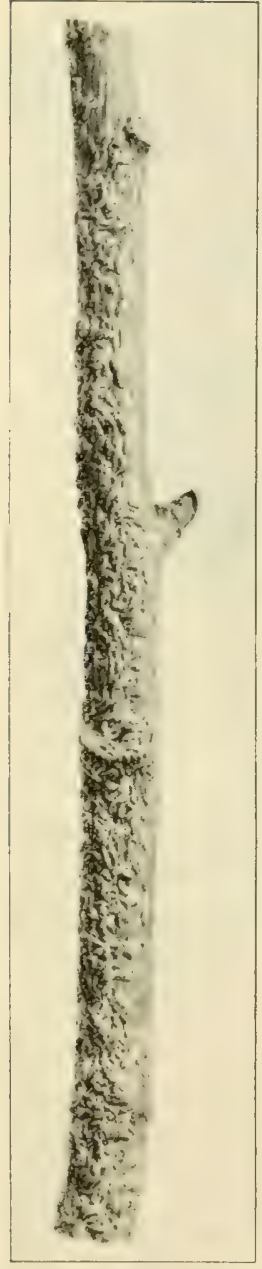

Farmers' Bullelin 723, U.S. D. A.

Fig. 104. One of the scale insects. thus escapes. The eggs of this insect are laid in holes which the mother bores into the young blossom buds, and as soon as hatched the young worm crawls inside the bud where he cannot be reached by poison. For the same reason there is not much chance of finding parasites for the boll-weevil larvæ. They spend their lives out of reach of such parasites. The only way to fight this insect is to rush the young cotton along so that at least a partial crop of bolls may mature before the weevils become so numerous as to get into every flower. The multiplication of the weevils may also be retarded early in the season by picking up and destroying the fallen blossom buds (the so-called squares) that contain the larvæ. Pictures of mature boll weevils, considerably enlarged, are shown in Figure 105.

\section{Things to Observe}

Mosquito eggs and larvæ. Look for "wrigglers" in stagnant water. These are the young of the mosquito. Observe how they shed their skins when fully grown. Look on the surface of the water for "mosquito boats." They look like a pile of very small cordwood. They 
are mosquito eggs. If you watch closely, you may see young wrigglers crawling out of the eggs. Why is it undesirable to allow stagnant water about the place?

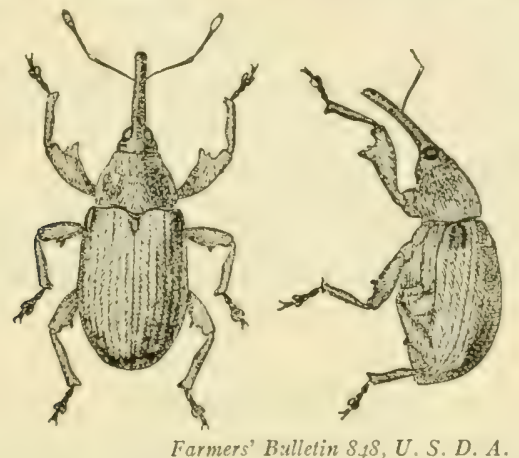

Fig. ro5. Mature boll weevils (enlarged to about five times natural size).

Ladybug larvæ feeding. Wherever you find plenty of "green bugs" (aphis), you are likely to find the young of the ladybug eating them. Watch for this.

Ants' "dairy cows." Watch ants that crawl about where there are aphis. They use these insects for much the same purpose as we use milch cows. The juice they get from the little "horns" on the back of the aphis is honey dew. A good place to observe this is on grapevines in summer. Some kinds of ants take care of the aphis eggs in winter and put the young aphids out to "pasture" in the spring.

Parasites on caterpillars. $\mathrm{By}$ watching carefully in late summer, you will occasionally find a large green "worm " with little cocoons hanging to its back. If you save these cocoons, they will soon hatch out into small flies. The mother fly laid her eggs in the back of the worm, and the young lived as parasites in the worm's body.

Insects carrying pollen. Watch insects visiting flowers. Do you find pollen on them? Do they get any of this pollen on the stigmas of the flowers they visit? 
Pupæ. In winter look for cocoons on the branches of trees and elsewhere. These have pupæ inside of them. Put some of them in glass jars and cover with cheesecloth. When warm weather comes, they will emerge as full-grown insects. The hard skin on a pupa is called a chrysalis.

Grasshoppers. Observe young grasshoppers. How do they differ from full-grown ones? In late summer watch where grasshoppers lay their eggs.

Biting and sucking insects. Examine the mouth parts of insects you find eating the leaves of plants. Examine also the mouth parts of those like moths, butterflies, and squashbugs, that feed only on juices.

\section{Experiment}

Put a little kerosene (enough to cover the surface) on stagnant water containing wrigglers. What happens to the wrigglers? What would be a good plan for getting rid of mosquitoes? 


\section{CHAPTER FOURTEEN}

\section{FUNGI}

IN Chapter Nine it was stated that all organic bodies are composed of cells, and that organisms are found consisting of any number of cells, from one to uncounted millions. Plants and animals whose bodies consist of relatively few cells, and which are simple in structure, are usually referred to as the Lower Organisms, while larger plants and animals of complex structure are called the Higher Plants and Animals.

Reproduction in the lower organisms. The higher plants reproduce mostly from seeds, the formation of which has already been given in some detail. The lower plants do not produce seed. In most of them there is a process of fertilization similar to that described for ordinary plants, but the fertilized cell grows directly into a new plant instead of forming a seed, though, like seeds, they may not begin their growth for a long time after they are formed. Some of the lowest plants, especially those consisting of a single cell, reproduce merely by division, without fertilization so far as known, though in some of them there is occasionally a union of two cells similar to that which occurs in fertilization. Many kinds reproduce in both ways; that is, an unfertilized cell may be cut off by division and set free to grow into a new plant, or certain cells may be set aside for the production of germ cells which must then unite with other germ cells before they can.grow.

Those plants in which the reproductive cells grow directly into new plants without the formation of seeds are called spore-bearing plants, and their reproductive 
cells are called spores. Ferns, mosses, and seaweeds are the largest and most conspicuous of the spore bearers. None of them produce seed. There are many thousands of other kinds of spore-bearing plants mostly small, or even microscopic, organisms.

Fungi. The office of green coloring matter in plants has been set forth in a previous chapter (page I 43 ). It enables the plant to utilize the carbon of $\mathrm{CO}_{2}$ in the air, and thus to form starch, the basic food material of plants. But when a plant has acquired the ability to live as a parasite on another plant, or on an animal, or when it has acquired the power of living on the dead remains of plants or animals, it is no longer dependent on the carbonic acid gas of the air, for it can obtain its food already prepared for it. Among the sporebearing plants a very large number of species have acquired the power of thus drawing their sustenance from other organisms, and have lost the power of producing the green coloring matter that formerly enabled them to produce starch. These degenerate forms are called fungi (singular, fungus). They play a very important part in agriculture, chiefly because of their parasitic habits. Some of them, however, render great service to the farmer, as we shall see.

Even some seed-producing plants have acquired the power of stealing their food from other plants, and some of these have no green coloring matter in them, but they are not classed as fungi. The common ghost plant, found in shaded woods, is an example. Its roots are attached to the roots of trees from which it obtains its nutriment. Mistletoe, although it is a parasite on 


\section{Fungi}

the limbs of trees, still produces the green coloring matter in its leaves and stems.

Bacteria. Bacteria are the lowest form of fungi. They are one-celled, and their bodies contain no chlorophyl (green coloring matter). As stated in an earlier chapter (page r34), they have no organized nucleus. Figures 74 and 75 (page 135 ) are actual photographs of two kinds of these tiny organisms, taken by the aid of a high-power microscope. An ordinary size for bacteria is $\frac{1}{25(1+1)}$ inch in diameter. This means that it would take 25,000 of them placed in a row to reach an inch.

These minute organisms play a most important part in nature. Having no chlorophyl, and hence being unable to manufacture starch, they must obtain their carbonaceous food either as parasites in other organisms or from dead organic matter. A few kinds have other ways of obtaining carbon.

By far the greater number of bacteria live in dead organic matter, but many other kinds are parasites, being responsible for diseases of various kinds both in plants and in animals. They are very abundant in nature, and are so small that a single grain of dust, barely large enough to be seen, may have hundreds of them sticking to its surface. One third of the weight of fresh manure is made up of them. A cubic inch of moderately rich soil may contain ten or twenty million of these tiny organisms, and always contains vast numbers. A single drop of sour milk usually contains several million bacteria, though fortunately the kinds ordinarily found in clean milk are useful rather than harm- 
ful. If all kinds of these small creatures could be kept out of a vessel of milk, it would never sour.

Bacteria, yeasts, and molds (see below) are all causes of decay. In obtaining their food from organic matter, they ordinarily use only a portion of the food material. They break up the molecules of the material on which they feed, and these large molecules, sometimes consisting of hundreds of atoms, give rise to numerous new organic compounds, some of which may have very disagreeable odors. They are abundant wherever any kind of decaying matter is found. It is nearly impossible to find a spot entirely free from them, ${ }^{1}$ but in such a place a piece of fresh meat could be hung up in the open air on a warm summer day without danger of spoiling; it would simply dry up. In the high mountains the air is so free from these organisms that sheep herders kill a mutton and leave it hanging in the open until it is all used up.

In canning fruits and regetables the organisms that cause decay are destroyed by heating the material to be canned, usually after it is placed in the cans. If the process is so performed that no living organisms are left in the cans, the food thus prepared keeps almost indefinitely. (See Figure Io6.)

Work of bacteria on organic matter in the soil. Starch and other easily digested foor materials are more or less plentiful in straw and in plant remains generally.

1 There are no bacteria in healthy plant or animal tissue, in crystals or solid rocks, or below a moderate depth (a few feet ordinarily) in the soil. It is not known how high they occur in the atmosphere, but few are found in the air on high mountains. 


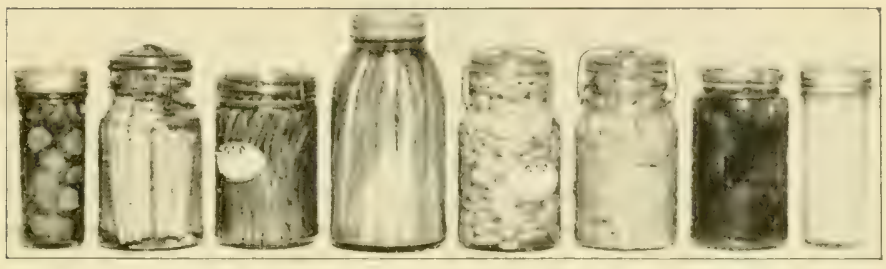

States Relations Serice, U.S. D.A. (O.F. Benson)

FIc. 106. A shelf of canned fruits and vegetables. These do not decay, because the germs which cause decay are absent.

before they have begun to decay. When vegetable matter is mixed with the soil, bacteria and other fungi; which are always abundant in a good soil, at once begin to use these easily digested materials as food. Much of the carbon contained in the organic matter is used, along with oxygen either from the organic matter or from the air, in the production of carbonic acid gas. It will be shown later that this rapid destruction of easily digested organic matter is important from the standpoint of soil fertility.

Other kinds of bacteria in the soil convert the nitrogen of organic matter into ammonium compounds.

As soon as ammonium compounds appear in the soil, bacteria found in all soils begin at once to convert them into nitrites, or substances containing the atomic combination $\mathrm{NO}_{2}$. Nitrites are poisonous to ordinary plants.

When nitrites become arailable, other bacteria at once begin to convert them into nitrates, or substances containing the atomic group $\mathrm{NO}_{3}$.

Since crops very generally prefer to have their nitrogen in the form of nitrates, it is easily seen that agri- 
culture would be practically impossible without these soil bacteria.

Unfortunately there are also very generally present in the soil other kinds of bacteria that, under conditions suitable to them, at once begin to destroy nitrates as soon as they appear in the soil. They break up the nitrates and set the nitrogen in them free, thus giving it back again to the air whence it originally came. Figure 107 shows the changes which different kinds of bacteria cause in the various classes of nitrogen compounds.

It is important for the farmer to understand how to prevent these bacteria from destroying the nitrates in the soil. They can accomplish nothing unless there is present in the soil such food materials as starch, sugar, or other easily digestible foodstuffs rich in carbon. This is the reason why it is important to ferment the starch, sugar, etc., out of vegetable matter before adding it to the soil.

If fresh manure, straw, and similar fertilizers be put on the land in the fall and mixed well with the soil, then by the time nitrate formation becomes active with the coming of warm weather in the spring the easily digested carbon-containing materials will all have been consumed by the numerous kinds of bacteria that thrive on them. Some of these are more or less active at all times during the winter except when the ground is actually frozen. The nitrate-destroying bacteria cannot cope with such a situation. They cannot break up the nitrates because they have no food of the kind they require to enable them to do this work. 


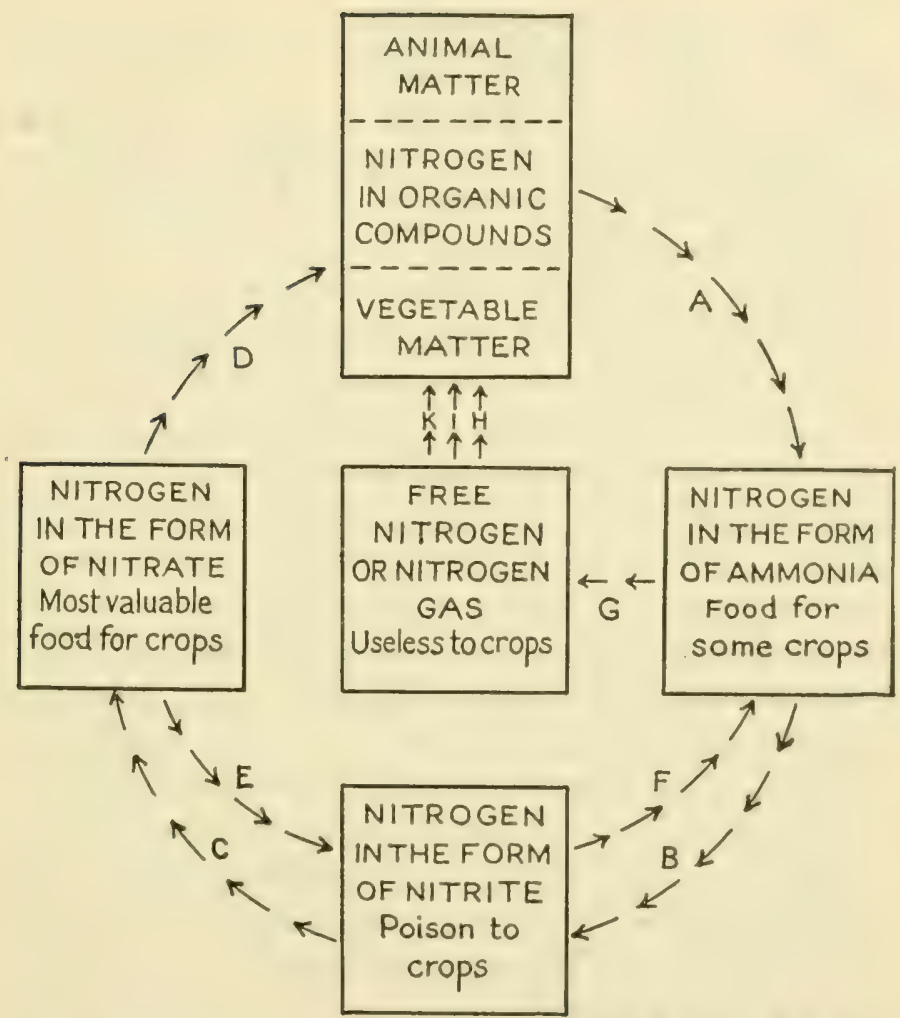

Year Book, U.S. D. A. (I000)

FIG. I07. Nitrogen changes produced in seil by atetion of bacteriat. The arrows indicate the course of the changes which various groups of hacteria may produce in the nitrogen compounds of the seil. .1 , al tion of ammonifying bateteria whith change organic nitrogen to ammonia ; $B$, action of nit rifying bacteria which change

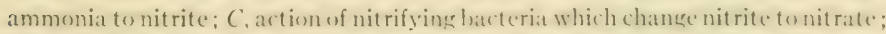
D). asvimilation of nitrate by green plants: Ea atton of denitrifying bacteria which change nitrate to nitrite; $F$, at tiun of denit rifying hacteriat which chanes: nitrite to ammonia; $G$, action of clenitrifying bacteriat which shange ammonia to nitrogen gas: $I I$, action of hacteria which change nitrogen gat into protedicl nitrogen ; $I$, action of hacteria which in symbiosis with legumineme plantechange nitrogen gas into foroted nitrugen; $K$, action of bacteria which in symlisuis with certain nonleguminous plant shange nitogen gas into proted nitrogen. 
Where manure is not abundant, it can be made to go farther by allowing it to ferment a few weeks before addling it to the soil, for in this way the food required by nitrate destroyers is taken out of the manure. In this fermenting, the manure should not be exposed to the weather, nor should it be left loose and open for air to get into. At the same time it should be kept moist. The best plan, where feasible, is to leave it under the animals that produce it, using plenty of bedding to keep the animals dry and clean. The next best plan is to place the manure in a covered manure pit to which the farm animals have access, and let them keep it well tramped down. In six or eight weeks it will be properly fermented and may then be spread on the land.

Rich soil always contains a considerable amount of vegetable matter. Bacteria thrive on this, gradually breaking it up and converting it into simpler substances. As the particles of organic matter in the soil fall to pieces and decay, they leave small openings in the soil. This tends to make the soil loose. It is therefore much easier to put a rich soil into a condition of good tilth than it is a compact soil containing little organic matter. Air and water also circulate better in a rich soil than in a poor one, unless the latter is quite sandy: Soil bacteria are thus seen to render very important service to the farmer.

Bacterial diseases. While most kinds of bacteria live in dead organic matter, there are not a few kinds that invade the bodies of living plants and animals, and live there as parasites. In a book of this size we can do little more than refer to this matter, hoping the 
student will later have an opportunity to learn more of the subject in his other studies. Many of our contagious diseases are due to bacteria. Tuberculosis is an example. In plants, one of the prominent bacterial diseases is pear blight. The organism that causes this disease lives in the cambium layer of the pear tree. Apple trees are also more or less subject to this disease. The leaves on infected branches dry up and turn brown or black. The only remedy is to cut off the diseased branches and burn them.

Higher fungi. The relation between the structure of bacteria and that of the more highly developed fungi may best be imagined by recalling the action of pollen

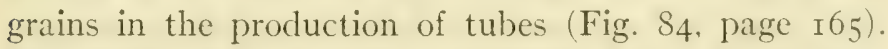
The pollen tube is a long, cylindrical outgrowth from the pollen grain. The higher fungi begin their growth from the spore, or single-celled stage, in much the same way as a pollen grain produces a tube. But in the growth of a fungus the spore sends out a threadlike growth which branches and rebranches until it makes a network of fine threads, usually within the substance on which it feeds. This threadlike growth is called the mycelium of the fungus. Each thread is filled with cytoplasm, just as any living cell is, and has nuclei here and there in it. Sometimes partitions form between the various nuclei in a thread, but this does not always happen. All these nuclei are, of course, derived, by division, from former nuclei. Figure ros shows the mycelial growth of a typical fungus of this kind. At the proper time certain branches of the mycelium throw out growths on which spores are produced and set free 
to begin the development of new individuals. Some of these "fruiting " branches are shown in the figure.

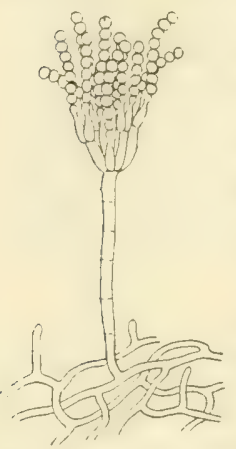

Fig. 108. Mycelium and fruiting portions of one of the simpler fungi, much enlarged.

Most kinds of fungi draw their sustenance from dead organic matter, but not a few kinds invade the bodies of living plants or animals, and thus give rise to characteristic diseases. While these invaders are very unwelcome "guests," the living body which they invade is called the host of the fungus.

Generally speaking, the mycelium of a fungus is found in the substance from which it draws its food, while the spore-bearing, or "fruiting," portion extends out into the air. In the case of several species of fungi parasitic in the bodies of living organisms, the spores are produced inside the body of the host, and obtain the chance to become scattered to other host plants only when the portion of the host occupied by them dies and decays.

The principal difference between the various fungi that produce a mycelium is in the form of the fruiting portions. In the simplest forms these are mere branches of the mycelium, forming spores at their tips. In the more highly developed forms the fruiting bodies are elaborately developed. Figure ros shows one of the simpler forms. Figure 109 is a diagrammatic representation of a toadstool, which is one of the more highly dereloped fungi. Note the large bundles of mycelium at the bottom. This mycelium penetrates the sub- 
stance from which the fungus draws its nourishment. usually a piece of decaying wood or other dead organic matter. The part which we know as the toadstool is merely the fruiting body. The spores are borne in minute, club-shaped bodies attached to the membranes on the under surface of the hood. A few kinds of toadstools send their mycelia down into the roots of living trees, and are thus parasitic in their habits. Most kinds are saprophytic, which means that they draw their nourishment from dear organic matter.

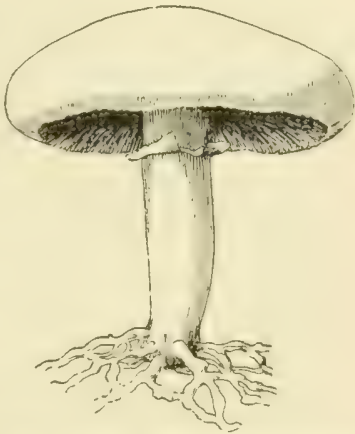

Fig. Io9. Diagrammatic representation of a toadstool, showing mycelium and fruiting body. The ront-like organs at the base are bundles of mycelial threads.

You have all noticed the fungous growths that form shelves on the sides of dead or dying trees. These often grow to be quite large, and their substance is hard and resistant. These growths are the fruiting portions of fungi the mycelium of which penetrates into the dead or dying wood of the tree on which they grow, and there obtain their food.

Yeast. The various kinds of yeast plants constitute an interesting and important group of fungi. Although they are, for the most part, one-celled organisms, their methods of reproduction show them to be degenerate forms of the higher fungi. Figure 73 . page 134 . shows several individual yeast plants, all but one in the act of "budding," which is one of the methods by which new individuals arise in these plants. 
The yeast used in making bread consists of a multitude of these tiny plants, along with starchy food material for their use. In their growth, they convert part of the starch on which they feed into alcohol and carbonic acid gas. It is the bubbles of this gas that cause yeast bread to rise. The alcohol in the dough is driven off in the process of baking.

Another kind of yeast plant is used in converting the starch of corn, rye, and other grains into alcohol. Yeasts take part also in the conversion of cider into vinegar. Yeast changes the sugar in cider to alcohol, and then other organisms convert the alcohol into acetic acid, the sour substance of vinegar.

Fungous diseases of plants. The number of plant diseases caused by fungi is so great that it is impossible in a book like this even to mention all of them. All that can be done here is to call attention to some of the more prominent of these diseases. It is hoped that this brief treatment of so important a subject will serve to arouse your interest, and lead you to observe closely such of these diseases as come to your attention. While most fungous diseases attack only a single kind of plant, there are a few that attack several different kinds. Practically every one of the higher plants is subject to one or more - sometimes many - fungous diseases.

Late blight of potatoes. The fungus that causes this very destructive disease belongs to a group known as the "downy mildews." Its spores light on the leaves or stems of potato vines, and begin to develop mycelia. These enter the breathing pores which are found in the 


\section{Fungi}

surface layer of all green plants and spread throughout the tissues of the host. When ready to produce new spores, branches of the mycelium come to the surface and produce there a downy growth from which the name "downy mildew" is taken. There are many" similar diseases. The only way to fight them is to cover the surface of the host plants with some kind of spray that will prevent the development of the spores which happen to find lodgment there. Copper sulfate is one of the substances much used in such sprays.

Powdery mildews. Another large group of fungous diseases is given the name "powdery mildew." The mildew so often seen on rose leares is one of the most common of these diseases. In this group the mycelium derelops on the surface of the host, and sends domn tiny rootlike organs into the tissues for food. They may be quite as destructire as the downy mildews. The blight which sometimes plays havoc in hopfields belongs here. Gooseberry bushes are often seriousiy injured by one of these blights. Copper sulfate sprays are also useful in combating this class of fungi. ${ }^{1}$

${ }^{1}$ There is an interesting story comnected with the powdery milelew of the grape. This disease is native to this country, occurrine on nur native graperines, on which it dees little injury: But when the discises got a foothold in Europe, it proved to be very destructive to the species of grapes grown there.

The value of copper sullate as a means of preventine the spread of funer was discovered in France in a curious way. I solution wi this substance was sprinkled on grapevines growing by a roadside te prevint passers-ly from stealing the grapes; when lo! it was discovered that vines thus treated were not attaked hy mildew, while other vines near by were badly affected. 
Grain rusts. The rusts commonly found on wheat and oats belong to another group of very destructive fungous diseases. The mycelium of the rusts develops inside the host plant, and the characteristic red and black spots on the surface of infected plants are only bunches of spore cases and spore-forming tissue of the parasite. These fungi produce spores in four different ways. One of the four kinds of spores is red and another black. The red spores of wheat rust usually occur on the leaves and the black spores on the stems of the plant. The little patches of spore-bearing growth are easily seen on infected plants.

A very striking member of this group is the orange rust of the blackberry, found more or less commonly over nearly all this country. It forms large and very conspicuous patches of a bright orange color on the leaves of blackberry bushes.

Smuts. Perhaps the most important of all the groups of fungous diseases is the one known as the smuts. Wheat, oats, barley, and corn are all subject to diseases of this kind. In the case of wheat and oat and barley smuts, the spores find lodgment on the surface of the grain, usually at threshing time. When the infected seed is sown, the smut spores germinate at the same time as the seed. The mycelium of the parasite invades the body of the tender seedling, and continues to grow inside the body of the host till the latter is mature and begins to form seed. The mycelium then invades the young seed and forms its spores within the seed. The seed of infected wheat is little more than a mass of smut spores. In some forms of smut even the glumes of the 
flowers of the host plant become filled with the spores of the parasite. Figure I IO shows a head of oats destroyed in this manner.

When infected grain is threshed, the smut spores are scattered among the non-infected grain and lodge on the surface of almost every grain. There are several very effective ways of killing these smut spores on seed grain. In some cases this is done by soaking the seed in hot water. In

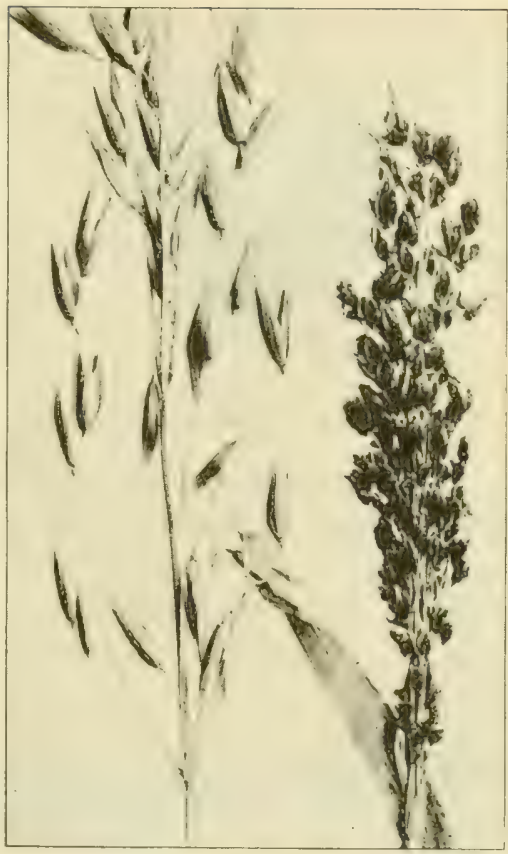

Cercal Investigations, U.S. D. A. (M. A. Carllon) FIG. IIo. Oats affected by smut (at rient).

others the seed is soaked in a solution of copper sulfate. A solution of formalin is also much used for this purpose.

Spot fungi. Many of the higher plants are subject to fungous diseases which cause spots, often very small and usually colored, to appear on the infected portions of the plant. In these spots are the fruiting portion of the fungus. You can find these diseases on numerous cultivated and wild plants. In fact, most discolored spots that appear on leaves are due to fungi. 


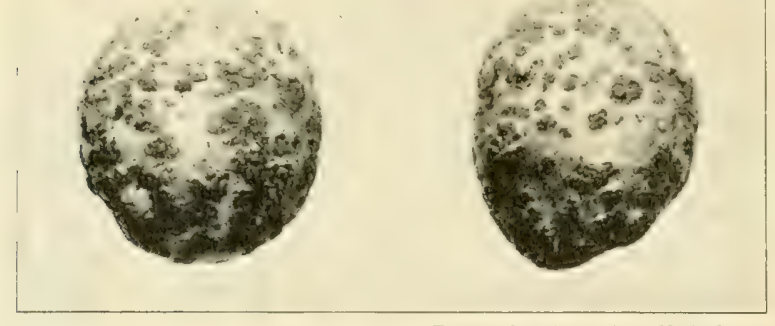

Farmers' Bulletin 865, U.S. D. A.

Fig. III. Potatoes affected by scab, a fungous disease.

Other important fungous diseases. Among the numerous fungous diseases not already mentioned are apple scab, potato scab (Fig. III), melon and cucumber blight, cotton wilt, cowpea wilt (Fig. I I2), apple canker, and tomato blight. You will learn more of these diseases in some of your later studies.

Sources of information. Since practically every crop the farmer grows is subject to one or more fungous diseases, as well as to attacks by insects, and since almost every one of these plant enemies differs more or less from others in the measures necessary for its control, it is manifestly impossible to give here the details of all these methods. Besides, scientists are continually learning new methods of fighting diseases and pests, so that the best of known methods one year may not be so the next. For these reasons it is necessary for the farmer to keep in touch with his state experiment station and with the United States Department of Agriculture. These institutions will send him bulletins giving the details of the latest methods. When any particular difficulty arises, the farmer should explain the situation to the 


\section{Fungi}

scientists of the state or national gorernment, giving them such information as they may require as to the nature of the dificulty, sending specimens of the diseased plants or of insects attacking his crops, and get from them such information as they may be able to give as to the best course to pursue. Unfortunately no satisfactory means of controlling some insect pests and plant diseases is yet known.

\section{Things to Observe}

Watch for mold growing on decaying fruit in cellars, and on such things as bread and cheese left in damp places. Put some bread or cheese in a damp, dark place and see if mold grows on it. The spores of molds are very widely scat-

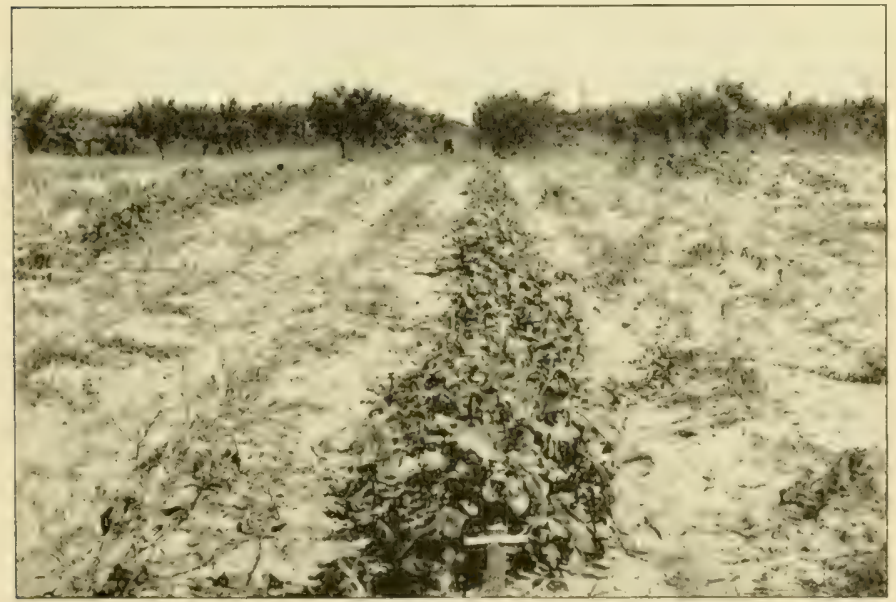

Bureau of Planl Indusiry, U.S. D. A. (Orlon)

FIG. II2. A row of iron cowpeas, a variety resistant to the fungous disease known as "cowpea wilt." Where the land is inoculated with this discase, this is a good variety to grow. Adjoining rows of uther varietie's have been killed by wilt. 
tered, and will alight and germinate almost anywhere. The mycelial threads are too small to be seen singly, but they often form webly masses that can be seen. The fruiting bodies of some of the molds can readily be seen by the aid of a small pocket magnifier.

If you happen to live in a region where potatoes are affected by late blight, see if you can find the downy growth of this fungus on potato leaves that are suffering from the blight. This disease belongs to the downy mildews.

The powdery mildew of the rose is very common in this country. Note its appearance on affected rose leaves.

Examine heads of wheat and oats that are affected by smut. In some parts of the country wheat is affected by stinking smut. It has a disgusting odor. This disease is common in the Columbia River basin. It is not the only kind of smut to which wheat is subject. The best time to observe these diseases is just before harvest. Nearly every cornfield has some smut in it. The spores of corn smut develop usually in the ear and husk. The affected parts become much swollen and distorted. When the smut is ripe, these swollen portions are full of a black powder, which consists of smut spores.

Rust can be found on wheat and oats nearly everywhere. Examine the rust spots on leaf and stem. The spots on the leaves of wheat are usually red, while those on the stem are usually black. This is due to the difference in the kinds of spores that form in these two situations. Nearly all grasses are affected by some kind of rust. Note the bright orange-colored rust commonly found on wild blackberry leaves. It sometimes covers several entire leaves.

Look for such diseases as apple scab (which forms rough places on the fruit, but also occurs on the leaves), potato scab, blight on muskmelon and cucumber vines, cotton wilt, cowpea wilt, tomato blight, canker on apple trees, pear blight, etc., etc. Pear blight usually spreads through an orchard soon after the blossoming season, for at that time 


\section{Fungi}

bees and other insects carry the disease from flower to flower in their search for nectar. The disease then grows down into the stem to which the flower is attached.

You can find spot diseases due to fungi on a great many kinds of plants. The spots are due to the development of the mycelium of the fungus inside the leaf. Only the fruiting portions of these fungi appear on the surface of the leaf.

Examine toadstools and mushrooms and note the difference in the structure of the fruiting bodies of the different kinds. Look for the bundles of mycelial threads in the soil beneath these fruiting bodies. Some toadstools are quite poisonous; so do not taste any kind not known to be good to eat.

Look for "fairy rings" in pastures. These are due to the action of fungi belonging to the toadstool and mushroom group. A toadstool gets started in a favorable location, and gradually spreads in all directions, dying out at the center where it started. As it spreads in the soil, it decomposes the organic matter on which it feeds, thus making more food available to the grass growing above. The grass grows more rankly in a circle just above where the mycelium of the fungus occurs in the soil. Sometimes the ring of rank grass is double, with a row of toadstools growing in a bare space between the two rows of rank grass.

Look for the very interesting cup fungi that are commonly found in damp, shady places. They are often abundant on the surface of the soil in grainfields just at harvest time. In some kinds the cups are about large enough to hold a grain of wheat. Some kinds look like miniature birds'-nests, with little eggs in them. The "eggs" are full of spores. The cups are the fruiting bodies of fungi akin to the toadstools.

Examine the green slime often found in stagnant water. It consists of very fine threads similar to the mycelium of a fungus, except that they contain chlorophyl. Some of the fungi are, in fact, degenerate relatives of this green-slime vegetation. 
Study the processes used in making yeast bread. The explanations given in the text should enable you to understand the reasons for the details of this process.

Late in the fall it is not uncommon to observe dead house flies on a window pane surrounded by a halo of fungus spores from a fungous disease that has killed the dead flies.

Chinch bugs are subject to a similar fungous disease. This disease has been propagated artificially amongst chinch bugs, and spreads rapidly in wet weather. In a dry season it is useless to try to spread it. 


\section{PART THREE - THE ANIMAL}

\section{CHAPTER FIFTEEN}

\section{PURPOSES FOR WHICH LIVESTOCK ARE KEPT ON THE FARM}

FARM animals are usually referred to as livestock. The various purposes for which livestock are kept are:

As work animals.

Is a means of producing home supplies of animal products.

As scavengers (consumers of waste products).

As a means of winter employment.

As a means of increasing the productive labor of the farm at all seasons.

As a means of converting farm crops into more valuable form.

For the production of manure.

For raising young animals for sale as breeding stock.

As pets.

On any given farm livestock may serve any or all of the above purposes.

Farm work stock. In countries where human labor is very cheap, as it is in China and India, many farms have no work animals. Some farms in this country are so small that it does not pay to keep work animals on them, and others need horse labor only a few days in the year. In such cases it is cheaper to hire horses when they are needed than to keep them the year round.

Eighty-two and one half jer cent of the farm work animals in this country are horses. Nearly all the re- 
mainder are mules. In the cotton fields and on the sugar plantations of the South mules are more common than horses, though most of these Southern mules are reared in the North. Nules consume a larger proportion of coarse roughage, such as cornstalks, sorghum fodder, etc., than horses. They are also less inclined to become nervous and excitable under rough handling. For both these reasons they are preferred by Southern farmers, who depend almost exclusively on Negro labor.

Oxen are occasionally used on farms in the South and in New England, but are rarely seen elsewhere. When the country was new and there was abundant idle land covered with nutritious grasses, oxen were important work animals on the farm. They could get most of their nourishment from these native grasses, and hence cost little for feed. Because of their slow motions, oxen do considerably less work in a day than horses or mules; and now, when they must be fed valuable hay and grain, it is usually cheaper to do farm work with horses or mules than with oxen.

Production of home supplies of animal products. On farms where the standard of living is what it should be, there are always found at least poultry enough to supply the home demand for eggs and poultry meat, a pig or two to supply fresh pork. hams, and bacon, and a cow or two to supply milk and butter. Unless the farmer keeps at least this amount of stock, the farm family seldom has as much of their products as it should have. Few farmers will pay out good money for things not absolutely necessary, even when they are deriving 
an excellent profit from their farms. Furthermore, when these things must be bought it is not possible to get them of as high quality as those produced on the farm.

Livestock as scavengers. On practically every farm there are materials that have no market value, and yet can be utilized as feed for stock. When properly used, these materials may arld many dollars to the farm income. The list includes cornstalks, straw, damaged or otherwise unsalable hay, grain wasted in harresting and threshing, weeds and weed seeds, and grasses and weeds growing in fence rows, along roadsides, and on rough, untillable land. Even insects are good feed for poultry. The wise farmer plans to keep enough stock to consume these materials. In order to do this effectively; it is often necessary to keep several kinds of animals, so that one kind will eat what another kind refuses.

The animals most frequently used for this purpose are poultry, cattle, hogs, and sheep, in the order named. On small farms the animals kept for the production of home supplies frequently consume all these waste products, so that no additional animals are needed for the purpose.

The farmer who does not keep as much stock as can be fed largely from these waste materials is losing an easy opportunity to make money. Frequently the amount to be made in this way would represent a fair profit on the farm business.

It is not alway's practicable to utilize. in the manner above suggested, all the cornstalks, straw, etc., produced 
on the farm. These materials are not sufficiently nutritious to constitute the entire ration of farm animals. A farm that devotes practically all its land to wheat, as is the case with many farms in the Pacific Northwest and in the northern portion of the Plains Region, produces enormous quantities of straw that can only be fed to advantage as a small part of the ration. There is nothing else on these farms to be fed with the straw. Under such conditions the farmer has no other recourse than to burn a large part of his straw. The amount of cornstalks produced on corn-belt farms is frequently so large that only a portion of them can be used as feed. In both these cases it may be possible sometime so to change the type of farming that other things can be grown to feed with the straw or cornstalks.

In most cases it is necessary to feed some valuable materials along with the waste materials of the farm in order to keep the stock in proper condition. It usually pays well to do this. If the stock produce enough to pay a little more than the value of the salable feed given them, and pay the other expenses of their keep, there is profit in keeping them.

Livestock as a means of winter employment. New Englanders sometimes remark that they have only three seasons: July, August, and winter. This is merely a joking way of referring to their long winters. In the far northern states the farmer can find work in his fields only about half the year. He cannot afford to be idle the remainder of the time, hence he tries to follow a type of farming that will give him winter work. The great majority of these farmers keep enough dairy cows 


\section{Purposes for Which Livestock Are Kept}

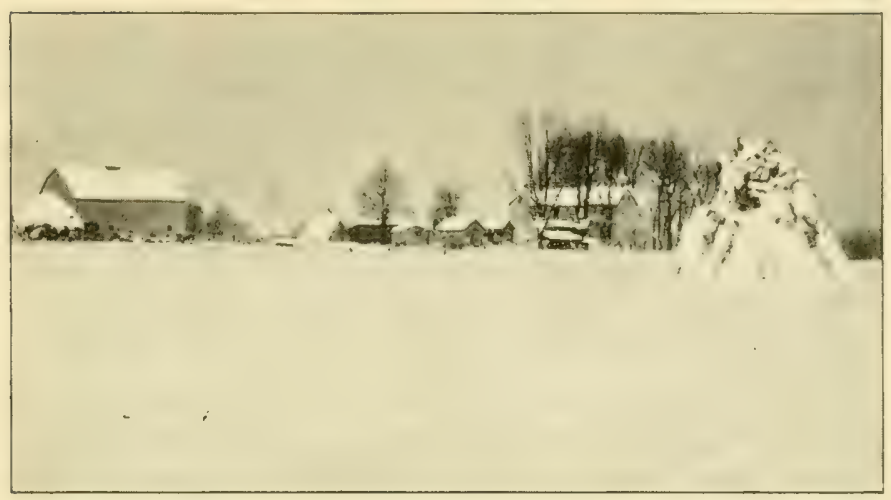

FIG. II3. The owner of this farm keeps dairy cows for the employment they give in winter.

to give them employment during the winter months. (See Figure Ir3.) A few find other ways of earning something at this season.

Even if the farmer cannot earn full wages for his work with a herd of cows during the winter, it may still pay to keep them, for whatever income the herd produces over the actual cost of its keep is just that much added to the farm income. This is true, of course, only where the farmer cannot find other work at which he could earn better wages.

The necessity for winter employment on something other than crops is largely responsible for the fact that, in both Europe and America, livestock are more important in the North than in the South.

Adding to the size of the farm business. A one-man farm should have enough work to keep the man well employed at all times, so that he may have a chance to utilize his full earning capacity; similarly; a two-man 
farm should provide work for two men; and so on. Often, however, a farm is too small to give full employment on crops alone. The addition of some kind of livestock will give more work, and if the stock pay anything more than the actual cash outlay they require, including the value of salable products fed them, their presence will add to the farm income. For this reason many small farms keep all the stock they can carry. It is possible in this way to convert a one-man crop farm into a two- or even three-man crop and stock farm. If the livestock are at all profitable, this will add materially to the profits of the business. We shall later learn that a two-man farm has important advantages over a one-man farm.

Livestock as a market for crops. A farmer who thoroughly understands the management of livestock can often get more for his hay, corn, etc., by feeding than by selling them. For instance, in many Western localities alfalfa hay has at times sold for less than $S_{7}$ a ton. When this hay is properly fed to good dairy cows, a ton of it will make SI 2 to $S_{1} 5$ worth of milk, or even more where milk is a good price. Under such conditions it is more profitable to feed the hay than to sell it. Even if it returned less than what it would sell for, it might still pay to feed it because of the additional employment the cows give and the manure they produce.

Another reason why it sometimes pays to feed rather than sell hay or grain is that the resulting animal product weighs less, and hence costs less to ship to market. Thus Io bushels of corn, weighing 560 pounds, will produce 


\section{Purposes for Which Livestock Are Kept}

Ioo pounds increase in live weight if properly fed to hogs. It costs less to ship the hogs to market than the corn. If the farm is situated a long distance from market, this may become an important matter.

Livestock as fertility producers. Many farmers keep livestock largely because of the fact that it gives them a supply of manure with which to keep up the yielding power of the soil. It may pay to do this even when the returns from the feed used are less than the price at which the feed might be sold. I once visited two arljoining farms in Illinois, both of which had about half their land in corn. One farmer sold all his corn, kept no livestock except work animals, and got about 35 bushels of corn per acre. The other fed all his corn to well-bred livestock, took good care of the manure, and got so bushels of corn per acre. It happened in this case that both farmers got about the same price for their corn; but it is easily seen that 80 bushels of corn per acre, even at 40 cents a bushel, brings in more money than 35 bushels at 60 cents. This is an extreme case, for the difference in yiekl is not often as great as this between two similar farms, one of which keeps livestock and the other does not. But when the farmer makes proper use of manure, the increase in the yicld of his crops may justify feeding under conditions that will return less for the feed than it would sell for.

Very little definite information is available concerning the actual value of manure on the farm. Much depends on how the manure is handled, on the kind of soil and its previous treatment, and the kind of crops to which it is applied, as well as the price of farm 


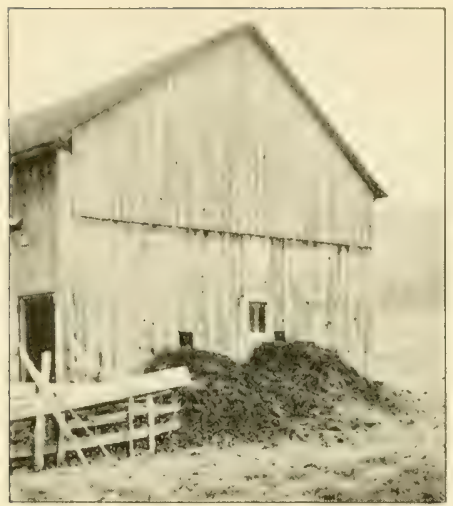

FIG. II f. Plant food wasting while the world goes hungry.

products. When manure is allowed to lie exposed to the weather for weeks or months, as was the case on the farm on which the picture shown in Figure II4 was taken, it loses much of its value.

In a farm-management survey in Pennsylvania, it was found that when the yields on 94 farms keeping much livestock were compared with those on $9+$ farms keeping little livestock, the increase in crop values on the farms having most stock amounted to S $5_{5}$ for every thousandpound animal on the farm. In other words, on this group of farms the farmers actually obtained $\mathrm{S}_{5} 5$ per year for the manure of each animal they kept. In similar studies in Michigan the amount was $\$ 8$, and in southwest Missouri $\$_{5}$. The Michigan farmers keep many hogs and relatively few cattle, and do not put on to the land as large a proportion of the manure produced as do the Pennsylvania farmers. The Missouri farmers did not take very good care of the manure.

The variation in the above values for manure shows the necessity for the use of judgment on the part of the farmer. There are localities, especially where the principal crops are garden vegetables, or other crops that produce large values per acre, where manure is undoubtedly worth more than the highest of these figures. But 


\section{Purposes for Which Livestock Are Kept 229}

in the dry-farming districts of the West manure may even be harmful unless it is applied with great skill. It may cause the land to become so loose that it will rapidly dry out.

As a general rule manure has a high value where the soil has been farmed a long time, especially if it has lost much of its original fertility, and where the rainfall is considerable. Under such conditions the farmer may find it profitable to feed livestock even if he does not get back the full value of the feed used. The loss may be more than made up in the increased yield of crops.

\section{RAISING YOUNG ANIMALS TO SELL AS BREEDERS}

Conditions necessary for success. To make a success of the business of raising animals for sale as breeders, the first requisite is that the animals must be of superior quality as compared with the common run of farm animals. They must also belong to some of the recognized improved breeds. Unless these two conditions are met, farmers will ordinarily not buy the animals for breeding purposes. The breed should be one that is in demand in the locality, for there will then be more buyers.

The farmer who engages in this business must have a distinct liking for the kind of animals he keeps. and must have decided ability as a breeder and as al sale:man. Nearly all successful breeders begin in a small way. with good stock bought at moderate prices. As their reputations grow, and they are able to get better and better prices for their young stock, they buy better stock themselves at higher prices than they could at 
first afford to pay. The most successful of these men finally get to the point where most of their young stock is sold at very high prices to other breeders rather than to farmers raising animals for meat or other products.

Not every farmer has the ability to become a successful breeder. It is necessary that the majority of stockmen engage in the production of meat, milk, wool, etc. But in every community where livestock are at all common there is room for a few men to engage in the business of raising breeding stock for others. The number of men in this business is not as large as it ought to be, partly because so many farmers will not pay a little extra for good breeding stock. This is a great mistake, for it pays well to have good stock. They produce more and better products, which sell at higher prices.

Registration. The adherents of each of the leading breeds of livestock in this country have organized associations for the purpose of furthering the interests of the breed. Each of these associations keeps a record of the pedigree of the animals belonging to the particular breed in which the association is interested. These records include a brief description of each animal, the date of its birth, the name and registry number of its sire and dam, and the name of the breeder. To be admitted to registration in these records an animal must conform to the recognized characteristics of the breed, and both its sire and dam must have been registered. When an animal has been accepted for registration it is given a number, and the owner is furnished with a "certificate of registration," which contains the description of the animal, its registry number, its name, 
Purposes for Which Livestock Are Kept 23I

the name and registry number of its sire and dam, and a statement signed by the secretary of the association to the effect that the animal has been accepted for registration as a representative of the breed. The essential features of a registration certificate are shown below.

\section{Certificate of Registration}

The Americax Deroc-Jersey Sime Breeders' Associmtiun .

Name No.

Farrowed

Litter

Bred by

P. O.

Sold to

P. O.

Date

Resold to

P. O.

Date

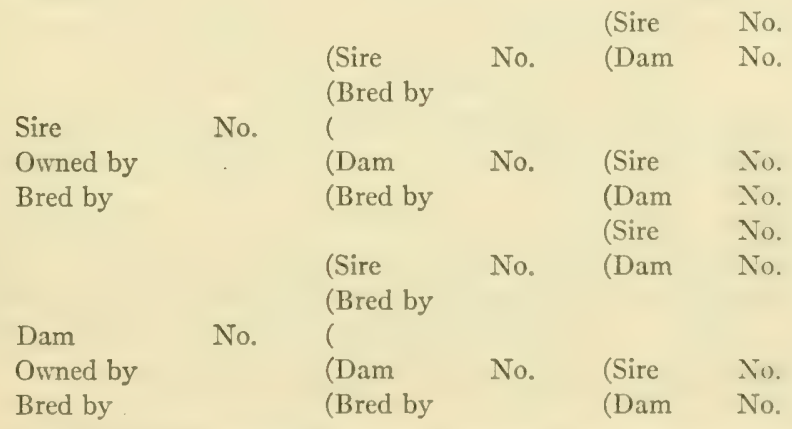

The original pedigree for this Certificate has been filed and accepted for Registration and we certify this to be true and correct.

Secretary's Office

ROBERT J. Evans

8i 7 Exchange Ave.

Chicago, Ill.

DATE Secretary

Some breeders do not register their young stock until they sell them as breeders or decide to use them themselves for breeding purposes. When they sell an unregis- 


\section{Farm Science}

tered animal, they furnish the buyer a signed paper giving all the information necessary for registration. The new owner, if he so chooses, sends this paper to the secretary of the association and gets the certificate of registration.

These associations charge a small fee for registering animals, as a means of defraying the expenses of the association.

'It is essential that every farmer who raises stock to sell as breeders should keep his own breeding stock registered in order to enable his patrons to register the animals they buy of him if they wish to do so.

\section{Class Exercise}

Take a census of all the livestock on the farms of the neighborhood of the school, noting the purposes for which the animals are kept.

What percentage of the horses, cattle, hogs, and sheep on these farms is purebred? high grade? low grade? mongrel? scrubs? To what breeds do they belong? Get each farmer's reasons for preferring the breeds he keeps. 


\section{CHAPTER SIXTEEN}

\section{BREEDS OF LIVESTOCK}

Definition of terms. If the sire and the dam of an animal - that is, its father and mother - both belong to the same recognized breed, the animal is said to be a purebred, or fullblood.

If one parent is purebred while the other belongs to no particular breed, the animal is said to be a grade of the breed represented by the purebred parent. Thus, a calf from a Shorthorn bull and a scrub cow is a grade Shorthorn.

Animals that have in them the blood of several of the recognized breeds but in which the blood of a particular breed predominates are also called grades. If in such a combination the blood of no particular breed predominates, the animals are mongrels.

A high grade is a grade the blood of which is more than half of some recognized breed. Thus a three-quarters Shorthorn is a high-grade Shorthorn.

Crossbreds are animals whose parents are purebred, but of different breeds.

The term scrub is applied to animals that do not contain any considerable proportion of the blood of any recognized breed.

The greater part of American farm animals are grades of the various improved breeds.

Relative value of grades and purebreds. For the production of meat, milk, wool, etc., high-grade or crossbred animals may be just as valuable as pureloreds; but for breeding purposes they are vastly inferior. 
Grades and crossbreds inherit different characteristics from their two parents. Now a hereditary quality inherited from both parents is transmitted to all offspring. But if a quality is inherited from one parent only, it will be transmitted to only about half the offspring. In the offspring of crossbred animals there is likely to occur any particular combination of the qualities of the original parents of the crossbred animals. The progeny of crossbreds and grades are therefore not dependable. It often happens that no two of such offspring, even from the same parents, are alike.

A very interesting example of what may happen when crossbred animals are used for breeding purposes is illustrated by the cross between the European wild hog and our common domesticated hogs. The wild hog has a very small stomach, and a correspondingly small appetite. The crossbred pigs are very much like the wild parent, and are thrifty. But among the progeny of these crossbred animals there are likely to be some individuals that inherit the small stomach of the wild hog along with the enormous appetite of the domesticated hog. These individuals kill themselves by overeating.

Importance of purebred sires. When grades or scrubs are mated with purebreds, the offspring are usually much like the purebred parent. It is therefore important that at least one of the parents should be purebred. Since the sire is half the herd from the standpoint of breeding, it is a matter of great importance that the farmer who wants to raise good animals should use purebred sires. 
Difference between purebred and wellbred. It must not be supposed that the breeders of any breed have succeeded in getting high quality in all the animals of the breed. Every breed has in it some animals that are no credit to it. It is therefore not enough that an animal be merely purebred; it must be wellbred. This means that it must have inherited from its parents those qualities possessed by the best animals of the breed. The mere fact that an animal is a purebred, or even a registered, Jersey does not insure that it possesses high dairy quality, for there are poor dairy cows even in this breed. The same is true of all the dairy breeds. To be successful as a breeder of livestock the farmer must learn to know a good animal when he sees one. It is true, however, that among purebreds one is much more likely to get what one wants in an animal than among grades, mongrels, or scrubs.

\section{BREEDS AND THEIR USES}

\section{Cattle}

Distinction between beef and dairy cattle. Some of the improved breeds of cattle have been bred' for many generations for strictly beef purposes, without much attention to milking qualities, while others have been bred strictly for milk production, with little or no attention to their beef qualities. This has produced two very distinct types of cattle, the beef type and the dairy type. A real dairy cow, no matter how well fed, will convert most of her food into milk rather than into meat, provided, of course, she is in milk. A real 


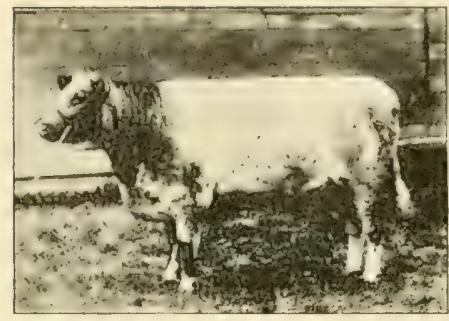

FIG. II5. Shorthorn.

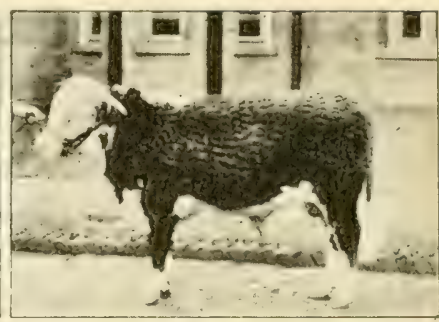

Bureau of Animal Industry, U.S.D.A. Fig. II6. Hereford.

beef cow, even when giving milk, will take on fat readily if abundantly fed.

In the breeding of beef cattle much attention has been given to securing roundness and plumpness of form, with small bone; while dairy cattle are angular and thin, with relatively large bone.

Another very important difference between beef and dairy cattle relates to the parts of the body where the most of the fat meat is found. In well-bred beef cattle a large proportion of the fat is found scattered in thin layers between the lean meat. This gives the meat a fine flavor. Dairy cattle place most of their fat, when they do get fat, inside the main cavity of the body around the kidneys, intestines, and other organs.

Beef breeds. The breed of beef cattle most commonly found in this country is the Shorthorn, formerly called the Durham (Fig. II5). They originated in Durham and surrounding counties in England. They are large cattle, red; red and white spotted, roan, or white in color, having rather small horns. Some strains of this breed incline more or less to the dairy type, and there are some good dairy cows among them. 
The next most prominent beef breed is the Hereford (Fig. I 16 ), large red cattle, with white faces and more or less white on other parts of the body. They have rather large horns. They originated in Hereford County, England.

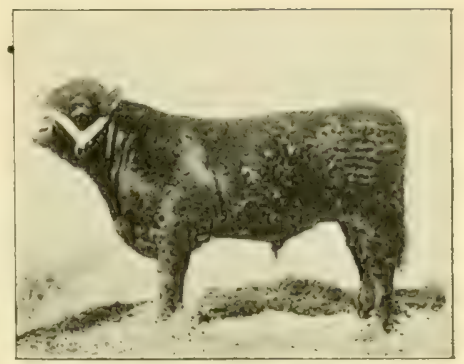

Bureau of Animal Industry, $L$. S. D. A. FIG. II7. Aberdeen-Angus.

The third most prominent beef breed is the Aberdeen-Angus (Fig. II 7), a breed of cattle coming from northern Scotland. They are black and hornless. When fat, their bodies are very round and plump. Their hides make good robes.

The Galloway is a breed much like the Angus, and came from a near-by locality in Scotland. Their coat is composed of rather long hair, and their hides make finer robes than buffalo hides.

The Polled Durham is a breed of polled, or hornless, beef cattle, developed in this country in two ways. Some of the originators of this-breed began by crossing Shorthorn cattle with native muleys (hornless cattle). From this cross many excellent polled cattle have descended. Others began by taking the occasional polled animals that occur in the Shorthorn breed, just as they do in nearly all breeds of horned cattle. From these pure Shorthorns they have developed well-known families of Polled Durhams. The characteristics of this breed are similar to those of the Shorthorn except for the horns. 


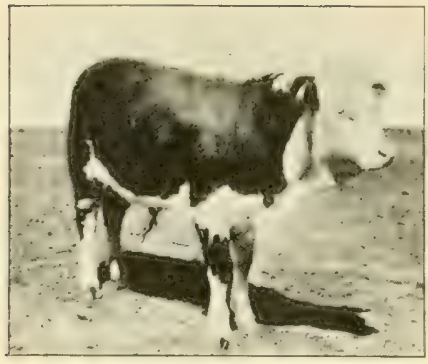

J. E. Greene, Muncie, Ind.

Fig. II 8 . Polled Hereford.

Polled Herefords (Fig. II8) originated in much the same way as the Polled Durhams. Some breeders searched the Hereford breed for hornless animals, finding a few of them. Others crossed Herefords with Polled Durhams to start with.

From the above it is seen that some Polled Durhams are also pure Shorthorns. Similarly, some Polled Herefords are pure Herefords. These animals that belong to two breeds are called double standard cattle.

There was a time when cattle needed horns with which to defend themselves against wild animals. But that time is past. The absence of horns is now a matter of considerable value, - so much so, in fact, that many horned cattle are dehorned to keep them from hurting each other.

Brahmin cattle (Fig. IIg), a breed from India, have been introduced into Texas and to some extent in other sections of the South. Their thick skin protects them from ticks, and in tick-infested regions they make much more rapid growth than ordinary cattle. They have a fleshy hump over

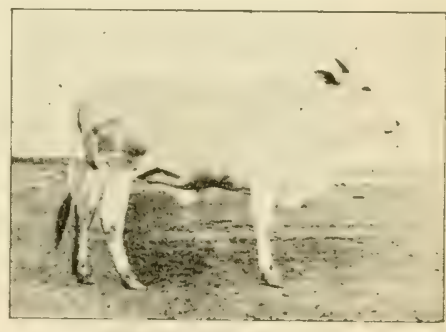

Farmers' Bulletin 612, U. S. D. A.

FIG. II9. Brahmin, the sacred cow of India. 
the shoulders and an enormous dewlap, or fold of skin on the lower margin of the neck. While they are used mainly for beef production, some of the cows are good milkers. They cross readily with the ordinary breeds, and even low grades frequently show marked in-

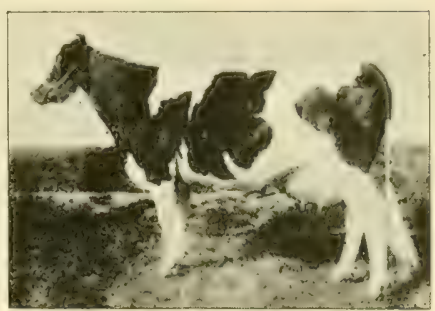

Dairy Division, U. S. D. A.

FIG. I 20. Tilly Alcartra, a California Holstein that gave $30,54 \mathrm{I}$ pounds of milk in a year. dications of Brahmin blood.

Dairy breeds. The leading dairy breeds of this country are the Holstein, Jersey, Guernsey, and Ayrshire.

Holsteins (Fig. I 20) are large, angular, black and white cattle that give a very large quantity of rather thin milk. They came from Holland and northwestern Germany. On the average they give as much butter as any breed, if not more. This breed is rapidly growing in popularity, especially in the northern and central parts of this country. Some Holstein breeders are giving attention to the richness of the milk their cows give. By the use of sires from families noted for richness of milk, much is being accomplished in this direction Holsteins are especially popular among farmers who ship milk to the cities, on account of the large amount of milk the cows give.

One breeder of Holsteins some years ago marle a careful search of the breed for polled Holsteins. He found over forty hornless animals of this breed and was able to buy nearly all of them. When he got them together and studied their pedigrees he found they were all de- 


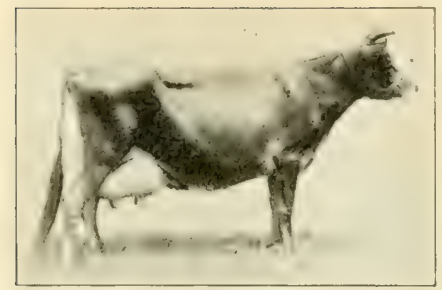

Duiry Dicision, U.S. D.A.

Fig. I21. Bosnian's Anna, a famous Jersey cow, owned in New Jersey.

scended from a single cow a few generations back. Part of these cows give milk that is quite rich. This breeder is rendering great service to this noble breed of animals. By proper use of breeding stock from this herd the whole breed can be dehorned in a few generations.

Jerseys (Fig. I2I) are small cattle that give very rich milk. In color they vary from yellow to red or even nearly black. Formerly there were many Jerseys spotted with white, but in recent years this color has been unpopular, and is now seldom seen. While this breed is found in all parts of the country, it seems to outdistance all others in the South. It comes from the island of Jersey, lying between England and France. These cattle grow somewhat larger in this country than they do on their native island.

There is also a polled branch of this breed, started some years ago by crossing with native muleys in this country.

Guernseys (Fig. I 22) come from the island of Guernsey, situated near the island of Jersey. Guernseys and Jerseys were considered one breed until about the middle of the last century.' They are much alike. Guernseys are somewhat larger than Jerseys, give a little more milk not quite so rich, and the butter made from their milk is yellower than that of any other breed. Guernseys rarely ever have black noses, while Jerseys nearly 
always do. The breeders of Guernseys have never made the mistake of insisting on solid color, so that Guernsey cows are usually spotted with white. This has given the breed an advantage which has been fully utilized. No breed can

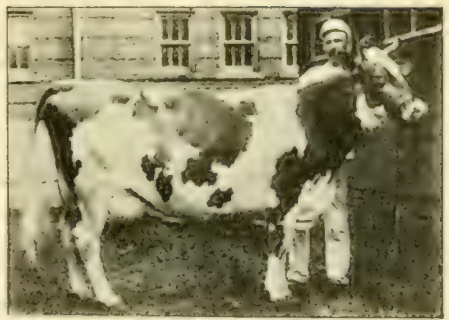

Dairy Division, U.S. D. A.

Fig. 122. Glencoe's Bopeep, a wellknown Guernsey cow, owned in Iowa.

afford to sacrifice its best animals for a fancy point such as color.

Thus far there is no polled branch of the Guernsey breed.

Ayrshires (Fig. 123) are a breed of dairy cattle coming from Scotland. They are especially popular in New England, though they are found more or less in all parts of the country. They are red (or brindle) and white spotted, often nearly white. Their horns stand up in a manner peculiar to the breed and easily recognized by any one familiar with these cattle. They do not give so much milk as the Holsteins nor such rich milk as Jerseys or Guernseys, but do especially well in hilly regions like their native home in Scotland.

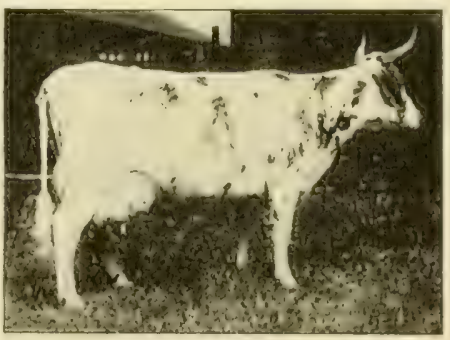

Dairy Dinisim, C. S. D). .1.

Fto. r23. Ayrshire cow, Lily of Willowmesor, owned in state of 11 astiugton. 'This cow gave 955 pounds of butter fat in a year. 


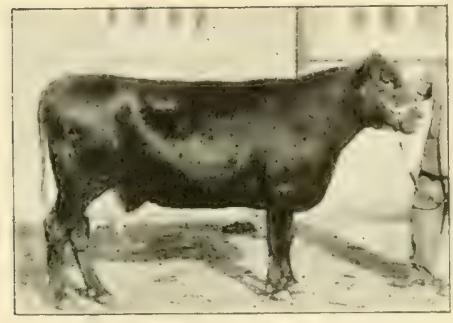

Animal Husbandry, U. S. D. A.

FIG. I2.t. Red Poll cow Liza; an Iowa prize winner.

Another breed of dairy cattle found in small numbers in some parts of this country is the Dutch Belted. They are of the same original ancestry as the Holsteins, and are much like the latter, except that the white on them is confined to a strip around the middle of the body. This gives them the appearance of black cattle with a white cloth tied around the body. It is usually a difficult matter to keep a breed true to a color character of this kind and at the same time improve its other qualities. Very few such breeds have ever risen to prominence.

General purpose breeds. The Red Polls and the Brown Swiss are two breeds of cattle more or less common in this country, that are intermediate between the strictly beef and the strictly dairy breeds.

The Red Polls (Fig. I24) are a deep, rich red in color, and are hornless, as the name suggests. There are many good dairy cows in the breed, but many others are of the beef type, and these are not good milkers. They came originally from England. In some parts of the country these cattle are popular among farmers who want to combine beef production with dairying, but are not so desirable for dairy purposes as the real dairy breeds.

The Brown Swiss, as the name indicates, came from Switzerland. This breed has become fairly common in 
some parts of the country. In color they closely resemble Jerseys, but are much fleshier. They serve about the same purpose as the Red Polls, but on the average are somewhat better milkers.

The Devon is another breed intermediate in type between the beef and dairy breeds. They are a deep, rich red, with rather long, slender horns. Most of the Deron cattle in this country are found in the Atlantic Coast states. They are less common now than formerly. The native home of the Devon is England.

Many other breeds of cattle are found in various parts of the world, and in small numbers in this country. The same is true of all other kinds of stock.

\section{Horses}

On the majority of farms horses are kept only for work. The number of colts raised per farm is small, and these are usually from mares kept mainly as work animals. Under such conditions the farmer hesitates to go to the expense of purchasing or even patronizing purebred stallions. For this reason a much smaller proportion of American farm horses are purebreds than is the case with cattle. A large proportion of the stallions used are at best only grades, and many of them are veritable scrubs. Farmers feel they can hardly afford to use high-priced purebred animals for ordinary farm work. There is no question, howerer. but what purebred animals would be profitalle for the farmer who is in a position to make a business of growing colts for sale, because of the much larger price he could get for them. 


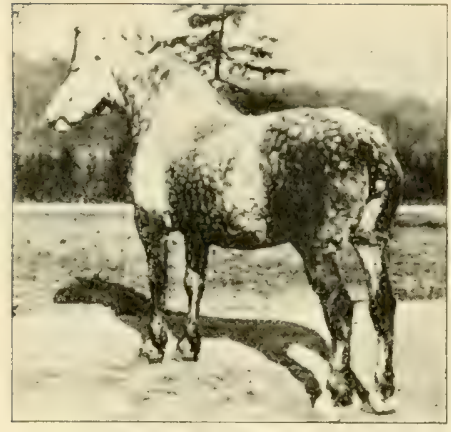

Animal II usbandry, U.S. D. A

FIG. 125. An Illinois draft horse of the Percheron breed.

Under the conditions above described it is natural that the various recognized breeds of horses should be less widely known among farmers than is the case with other classes of farm animals.

The recognized breeds of horses may be divided into two great groups, one represented by the large animals constituting the draft breeds, the other by the smaller animals.

Draft breeds. The principal draft breeds found in this country are the Clydesdale, from Scotland; the Shire, from England; the Percheron, from France (Fig. I 25); and the Belgian, from Belgium. Norman horses are in this country included with the Percherons. They come from another part of France. The horses of all these breeds are large and powerful, and are much used as draft animals in cities. They are used for farm work for the most part only by farmers who make a business of raising colts for sale.

Light breeds. The leading breeds of light horses in this country are the Thoroughbred, or English Race Horse; the American Trotter (Fig. I26), descended mostly from the Thoroughbred; the American Saddle Horse, also descended from the Thoroughbred and from representatives of the Trotter; and the following breeds of coach horses: Hackney and Cleveland Bay, both 
English in origin ; French Coach; and German Coach. Since the advent of the automobile the coach horse is less used than formerly.

The English race horse was the first breed of any kind of farm livestock for which a system of registration was established. This is how these horses

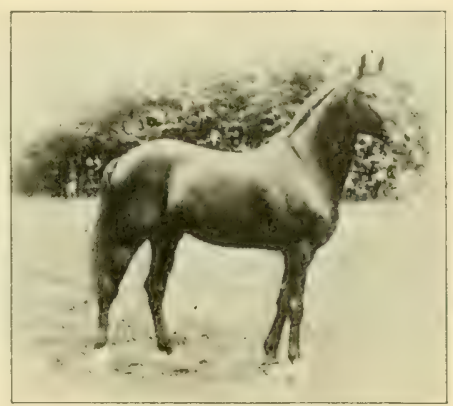

Animal II usbandry, U. S. D.A.

Fig. I 26. Jackdaw, a Kansas-owned standard-bred trotter.

came to appropriate the name Thoroughbred.

The American trotter is the best known of any of the breeds of light horses. In some parts of the country, especially in Virginia and Kentucky, they are found on many farms.

The American saddle horse is found most generally in Kentucky. To be admitted to registry in this breed a horse, in addition to being a good walker, must be able to trot, rack (rapid pace), and canter (slow gallop), and be able to exhibit either the running walk (fox trot), slow pace, or fast trot.

The three breeds last mentioned all trace back to the famous Arab horses of Arabia and Persia. All the heary breeds trace back to the large horses found in Belgium at the beginning of modern history:

Ponies. While ponies are not used as farm horses in this country, they are common enough to deserve mention. Farms are found here and there that make a business of raising shetland ponies, chiefly as pets 


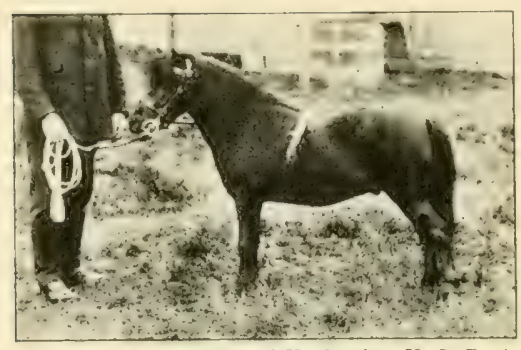

Animal II usbandry, U.S. D. A.

FIG. I27. Shetland pony.

for city children. There are several breeds of these small horses, the mostprominent being that from the Shetland Islands, off the coast of Scotland. (See Figure I27.) It is commonly supposed that ponies tend to increase in size when kept in this country for several generations, but the largest breeder of ponies in the United States claims that this is not the case. He has ponies as small as any found in their native home.

Mustangs and cayuses. The mustangs, now more frequently called broncos, are not a recognized breed, but are a recognized type. They are the small, tough horses found in Texas and surrounding states. They are descended from the horses brought over to Nexico by the early Spanish settlers. Another off shoot of this same stock is the Indian pony of the Pacific Northwest. In that region they are called cayuses ( $\left.k \bar{i}-\bar{u} s^{\prime} e s\right)$, the Indian name for them. Cayuses have better dispositions than broncos.

The great majority of American farm horses are descended from horses brought to this country by the early settlers along the Atlantic coast. They are of no particular breed, but are gradually being graded up by the use of stallions of the recognized breeds.

The automobile and the tractor are beginning to lessen the demand for horses. 


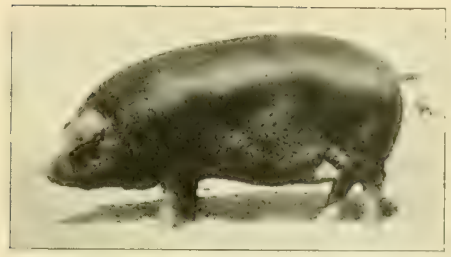

Animal Husbandry, U.S.D.A.

FIG. I28. Duroc Jersey, a red hog.

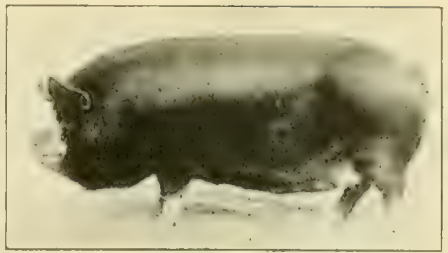

Animal Husbandry, U. S. D. A.

FIG. I29. Berkshire, black with white points, dish faced.

\section{Swine}

There are so many breeds of swine, differing so little in essential characteristics, that it is unnecessary here to speak of each of them. A few of the more important will be mentioned briefly. Most of the hogs of this country are either grades or purebreds of some of the recognized breeds.

The leading breeds are the Duroc Jersey (Fig. I2S), a red breed, the Berkshire (Fig. I 29), and the Poland China (Fig. I 30), both black breeds with white "points"; that is, they have white feet, a white star in the forehead, and white on the tip of the tail. The Berkshire has a dish face. Yorkshires are white, dish-faced hogs, found frequently in the northern states. The Chester White is another white breed common in the North. White hogs do not do well in the hot summers of the South. They blister badly. The Hampshire is a breed

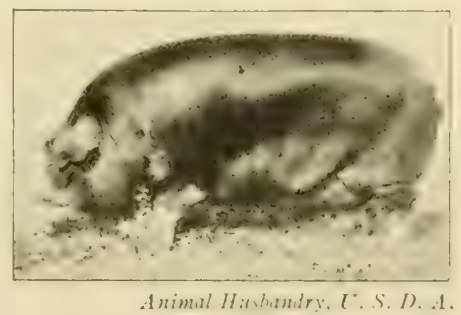

FIG. 130. Poland China, black with white points. 


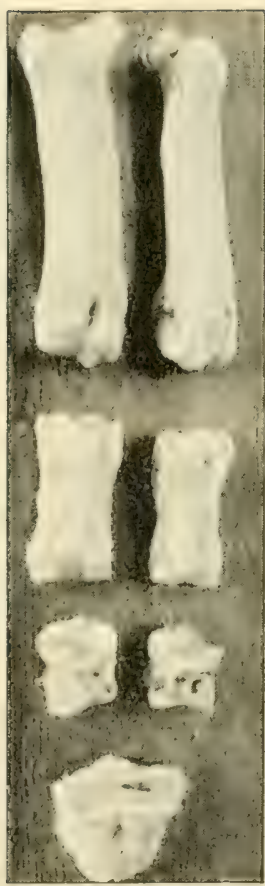

Fig. I3I, Bones from foot of mulefoot hog. The end bone consists of two bones grown together.

similar in color to Dutch Belted cattle. They are black with a white belt at the shoulders (not at the middle of the body as in the Dutch Belted cattle).

The main thing in the raising of hogs is to have sows that bring large litters and raise them. Duroc Jersey and Berkshire sows have good reputations in this respect, though the Poland China does about as well in the hands of a careful breeder. Poland Chinas are lazy, Berkshires are very active, and Durocs are intermediate in this respect.

Mulefoot hogs have the bones of the two main toes on each foot united into a single toe (Fig. I3I). Many farmers think mulefoot hogs will not have cholera, but in this they are mistaken.

Numerous other breeds of hogs occur in small numbers in this country.

\section{Sheep}

The many breeds of sheep in this country may be divided into wool types (Fig. 133) and mutton types (Fig. I32). The mutton types may be again divided into those with long, coarse wool and those with wool of medium length and rineness. The wool types have fine, short wool. 


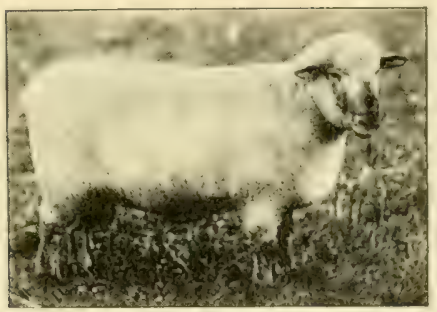

Animal Uusbanlry, U.S.D. A.

FIG. 132. Shropshire, one of the mutton breeds.

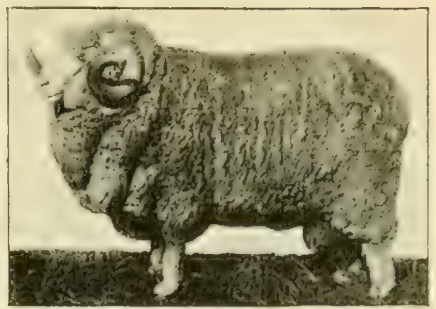

Animal Husbantry, U.S. D. A.

FIG. I33. Merino, a wool breed.

The wool types, or fine wool types as they are frequently called, are all descended from the old Spanish Merino. They are small sheep, and do not make the best of mutton. Before the recent rise in the price of all kinds of meat the Merinos outnumbered all other breeds together in this country. They were almost universal on the Western ranges. There are many more or less distinct breeds of Merinos.

The principal medium-wool mutton breeds are the Shropshire, Oxford, Southdown, Hampshire, Dorset, and Cheviot, all of English origin.

The leading long-wool mutton breeds are the Cotswold, Lincoln, and Leicester, all from England.

Merino sheep have been herded on ranges from time immemorial, while the mutton breeds of English origin have been reared on farms. Ranchmen in the West find that when they introduce much of the blood of the English breeds into their flocks, as they have done to a considerable extent in recent years, the sheep do not stay together well in large flocks, but tend to straggle off in small bunches. This makes it difficult to herd them. 


\section{Goats}

The common goats of the country are kept in small numbers on farms here and there, mainly as pets. They

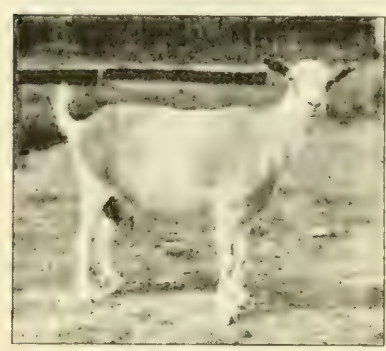

Animal II usbandry, U.S. D. A.

Fig. I34. Common goat. are much more common in the South than elsewhere. Their only commercial product is meat, which, in young animals, is excellent. On farms having little livestock a few goats can be kept at small expense, and the kids sell readily for mutton. (See Figure I34.)

On the Western ranges, and occasionally on farms, flocks of Angora goats occur (Fig. I68, page 319). This is an improved breed, noted for the great length and fine quality of its fleece, which is called mohair. This breed came originally from the province of Angora in Asiatic Turkey. There are many more Angoras in this country than there are of the common goat, but they are not so widely distributed.

A few representatives of milk breeds of goats from Asia and Europe have been brought to this country, but they are as yet of little importance. Some of them give large quantities of milk, especially valuable for sickly infants.

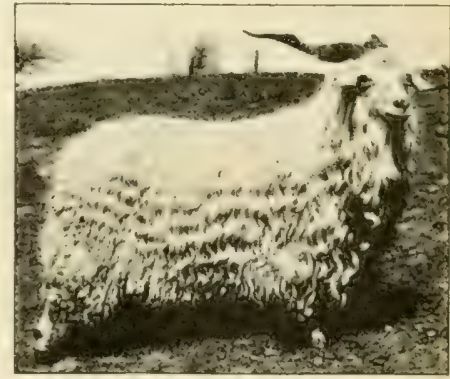

Animal Husbandry, U. S. D. A.

Fig. 135. King Cromwell, a Kansasowned Angora. 


\section{Poultry}

At the census of rgio the number of the difierent kinds of poultry in this country was as follows:

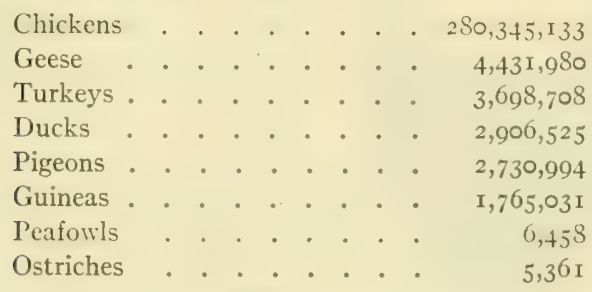

As compared with the previous census the number of chickens was 20 per cent greater; geese 22 per cent, turkeys 44 per cent, and ducks 39 per cent fewer. Ostriches increased considerably in number. They are found in southern California and in Florida. They are not financially profitable in this country except as show birds. Pigeons, guineas, and peafowls were not included in the census for I900. Chickens constitute 95 per cent of all the fowls kept on American farms, and these figures show that this percentage is increasing.

\section{Breeds of Chickens}

There are about forty distinct breeds of chickens in this country, and each breed is split up into varieties differing from each other mainly in color and in the character of the comb. The principal color varieties found are white, black, buff or red, barred, laced, speckled, etc. The types of comb are plain, rose, pea, walnut, and V-shaped. Only plain and rose comb are common. 
While there are many poultry-breeding associations, there is no means provided for registering individual

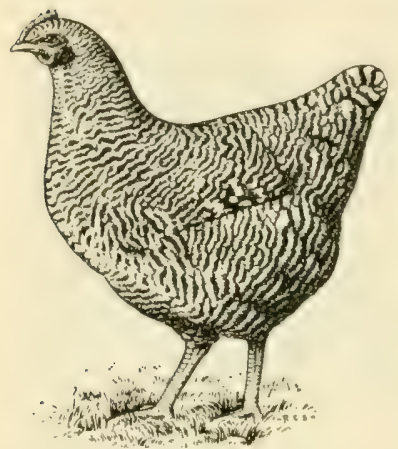

FIG. I36. Barred Plymouth Rock, a general purpose fowl. birds, because under farm conditions it is not ordinarily practicable to know the exact parentage of each bird. Instead of registration books, the American Poultry Association has established what it calls Standards of Excellence, to which birds must conform before they are admitted to the poultry shows. These standards relate mainly to color, shape of the comb, size and shape of the body, constitutional vigor, etc. The breeding associations are now beginning to give more attention to such qualities as egg laying, value for meat, etc. The farm poultry of this country would today be much more valuable to the farmer if these associations had always given as much attention to useful qualities as they have to "fancy points."

The various breeds of chickens may be divided into four main groups; namely, general purpose breeds, egg breeds, meat breeds, and fancy breeds.

General purpose breeds. The birds of these breeds are of medium size, are good layers, the hens sit well, and the young birds are excellent for the table. For an ordinary-sized farm flock they are perhaps the best types for the farmer. The best of them produce nearly as many eggs as the best 
of the egg breeds, they require less attention than the latter, and are readily salable at good prices for meat.

Among the large number of breeds of this class the most important are the Plymouth Rocks (Fig. I36), Rhode Island Reds, and Wyandottes. Among the Plymouth Rocks the Barred variety is by far the most popular. It is one of the best farm birds in this country, though the Rhode Island Reds have been advancing in favor rapidly in recent years. White Wyan-

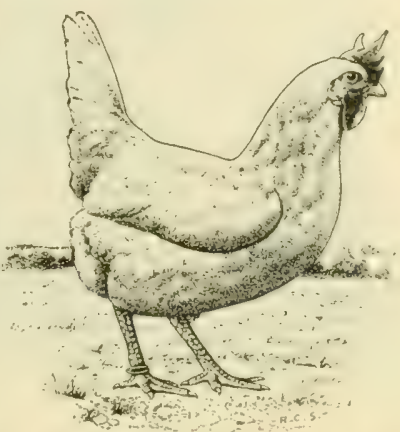

Fig. 137. Lady Eglantine, a Maryland-owned White Leghorn. This hen laid $3 \mathrm{rt}$ eggs in one year, a world's recurd.

dottes are also favorites with many farmers. These three breeds are of American origin. The Orpingtons, of which there are several varieties, came from England, and are becoming fairly common in some parts of the country.

Egg breeds. These are small to medium-sized birds, not very good as table birds, but noted for laying. The hens are seldom inclined to sit, so that they are specially adapted to farms which make a specialty of egg production and hatch eggs in incubators. Nearly all the large poultry plants keep birds of these breeds.

The principal breeds of this class are the Leghorns, Minorcas, Andalusians, Hamburgs, and Spanish. All of these except the Hamburgs came originally from Italy or Spain, for which reason this class of breeds is frequently called Mediterraneans. 


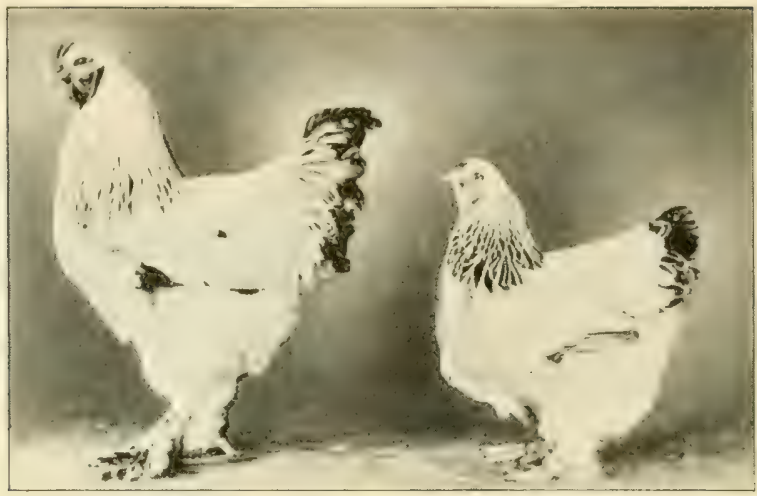

Animal Husbandry, U.S.D.A.

FIG. I38. Light Brahmas, a meat breed.

The Leghorns are by far the most popular of the egg breeds, especially White Leghorns. Lady Eglantine (Fig. I37), the bird that laid 3I4 eggs in a year, was a White Leghorn. The Brown Leghorn is also quite popular amongst poultrymen. It is noteworthy from the fact that in color and body form the Brown Leghorn is remarkably similar to the wild jungle fowl of India, which is supposed to be the original ancestor of our domesticated chickens.

One variety of Andalusians, the Blue, is of interest from the fact that it does not breed true to color. For many years breeders have tried to fix the color of this variety, but it is now known that this is impossible. The blue birds are hybrids between black and white. If mated together one fourth of the progeny will be white, one fourth black, the remaining half being blue hybrids again. White Andalusians are not pure white, being more or less splashed with blue. 
Meat breeds. These are large birds, mostly of Chinese origin. They are poor layers, mature slowly, but make excellent eating. The hens are persistent sitters. The principal breeds are the Cochins, Brahmas (Fig. I38), Langshans, and Favorelles (of French origin). None of these breeds are common on American farms, and their numbers are

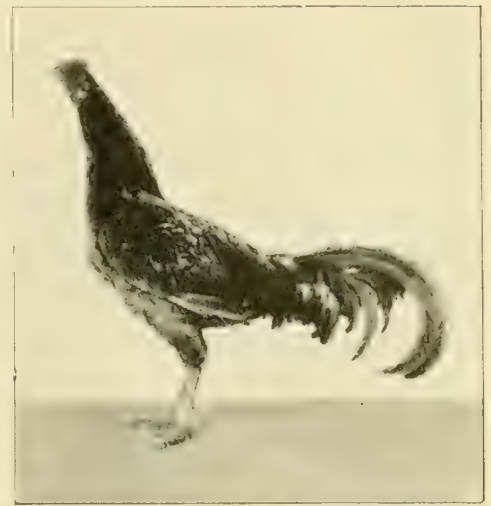

Animal Hustundry, L. S. D. A.

FIg. I39. Game chicken, noted for its fighting qualities, and also for the tine flavor of its tiesh.

decreasing because of their low egg production.

Fancy breeds. There are numerous breeds of chickens kept by poultry fanciers mostly to exhibit at poultry shows, but which are seldom found on the ordinary farm. The various varieties of Game chickens (Fig. I 39) are included here. These birds (Games) are noted for fighting. Their meat is also exceptionally fine-flarored. Bantams also may be mentioned. They are extremely small chickens, kept merely as curiosities.

\section{Class Exercise}

Estimate the average egg production per hen of the various farm flocks on several farms. Note the breeds of poultry kept. 


\section{CHAPTER SEVENTEEN}

\section{PRINCIPLES OF FEEDING}

Uses of food. Young animals need food to build the new body substance formed as they grow. But even in mature animals each of the cells of which the body is composed wastes away more or less as a result of the bodily activities or vital processes, and food is necessary to replace the materials thus lost.

The animal body must also be kept warm. Food is burned in the body to accomplish this. How this burning takes place will be told shortly.

Animals are also active beings. They do work, even if nothing more than moving themselves about, eating, etc. The heart works incessantly, pumping the blood through the blood vessels. A lot of work is done in breathing. The body can no more do this work without a supply of energy than can an engine turn machinery without a source of energy. The burning of food in the body supplies the energy needed by the organism.

When food is supplied in abundance, some of it is converted into fat and stored in convenient places about the body for use at some future time when the supply of food may run short. This fat cannot be used for making new growth of bone, muscle, etc., but serves merely as fuel to furnish heat and energy.

Combustion. Let us recall what was said about combustion in an earlier chapter (page I3I). Combustion is merely another name for burning. It is important to understand what happens when anything burns. Wood contains much carbon and some hydrogen. 
Both of these elements attract oxygen strongly. We have already learned that when carbon unites with oxygen it forms carbonic acid gas $\left(\mathrm{CO}_{2}\right)$. When hydrogen unites with oxygen it forms water $\left(\mathrm{H}_{2} \mathrm{O}\right)$. These chemical unions result in the production of enormous quantities of heat. If the burning is rapid, high temperatures are produced. If it takes place slowly, the heat is dissipated nearly as fast as it is formed, so that little rise in temperature occurs.

How an engine works. The fire in an engine is due to the chemical union of atmospheric oxygen with the carbon and hydrogen of the fuel. The resulting heat converts some of the water in the boiler into steam, which occupies a great deal more space than the water did. This causes great pressure within the boiler. Some of the steam is admitted into the cylinder and presses against the piston, causing it to move. This sets the flywheel in motion, and the engine is then in condition to do work. The energy of the fuel is thus transformed through several stages into motion of the flywheel.

Production of heat and energy in the animal body. When food is taken into the digestive organs, it is more or less completely dissolved by the digestive juices. The solution passes by osmosis through the walls of the digestive organs and of the fine blood ressels in these walls, thus gaining admission into the blood. Oxygen from the air is taken into the blood in a similar manner in the lungs. In the blood the carbon and hydrogen of the food unite chemically with this oxygen, thus producing heat to keep the body warm, and energy 
for the activities of the body. Actual combustion therefore takes place in the body. But this combustion is allowed to take place only slowly, so that the temperature may not become too high, and so that energy may be produced when and where it is needed. The complete story of the burning which takes place in our bodies is too long to tell here. It is one of the subjects constituting the science of physiology.

Classes of food substances required by the animal body. For the proper nourishment of the animal body five classes of substances are necessary in the food. First, there must be nitrogenous substances; that is, substances containing the element nitrogen, for every part of the body except the fat consists partly of nitrogen. These nitrogenous substances in food are known by the general name protein.

Second, the food must contain a number of mineral substances, for the bones consist largely of mineral matter (mostly lime phosphate), and there is some mineral matter in every organ, even the red meat or muscles. Certain mineral substances, especially common table salt $(\mathrm{NaCl})$, also are required for the process of digestion.

In the third place, the food must contain a large quantity of combustible material for the production of heat and energy. Substances like sugar and starch, which consist of carbon, hydrogen, and oxygen, and which are called carbohydrates, serve well as fuel. Fats also serve for this purpose, for they are combustible. The nitrogenous substances of the food contain also carbon and hydrogen which may serve as fuel. 
Finally, there are at least two substances that we know very little about except that they are necessary in food, and that one of them is soluble in oils and fats. while the other is soluble in water. These substances have been given the general name vitamins.

To recapitulate: Food must contain proteins, mineral substances, combustible materials, and two kinds of vitamins.

Sources of the various food constituents. Proteins are found more or less in nearly all feeding stuffs, but are much more abundant in some than in others. They are especially abundant in the seeds, leaves, and stems of leguminous plants (page I48), and in certain mill byproducts, such as cottonseed meal, linseed meal, gluten feed, etc. Milk contains them in about the proportion needed.

The animal body requires seventeen or eighteen different protein combinations. Few feeding stuffs contain all of these, hence it is necessary to feed a variety of materials to insure that all necessary kinds are provided. The soy bean and the peanut are not only rich in them, but they contain a wide variety of protein combinations. The seeds of peas and beans are rich in protein, but do not contain all the kinds needed. Corn, wheat, and oats, though not rich in these substances, contain kinds lacking in peas and beans, and hence are good to mix with the latter. Root crops contain a good assortment of proteins, but not in large quantity.

Corn stover and hay made from such grasses as timothy, red top, orchard grass, Johnson grass, and the like, are poor in protein. 
The mineral substances required by the animal body are abundant in the leaves of plants, in milk, and in fruits. They are deficient in seeds and in root crops.

The most common carbohydrates in feeding stuffs are starch, sugar, and cellulose (the substance of which the cell walls of plants are made). They are usually much more abundant than any other class of nutrients in common feeding stuffs. They are especially abundant in the seeds of corn, wheat, oats, and barley, in silage, and in non-leguminous hay. Milk contains considerable sugar.

Fats, or oils, are abundant in certain kinds of seeds, especially soy beans, peanuts, and flaxseed. All common feeding stuffs contain at least small quantities of oils. Milk contains from 3 to 6 per cent of butter fat. A pound of fat (oil) is equivalent to $2 \frac{1}{4}$ pounds of starch. or sugar in the amount of energy it furnishes when burned in the body.

The fat-soluble vitamin is abundant in milk, egg yolk, and the leaves of plants. It is especially abundant in butter. It is lacking or present in only small amounts in most kinds of seeds, in vegetable oils, in lard, and in meats generally.

The water-soluble vitamin is abundant in milk, egg yolk, seeds, and leaves. It is absent or in only small quantity in starch, sugar, fats, polished rice, and fish. It is the absence of this vitamin in polished rice that causes a serious disease known as beriberi in people who live largely on this article of food.

Proportion of protein and fuel needed. The animal body needs much more fuel than it does protein, the 
proportion depending on age, work done, whether the animal is being fattened or merely kept in good growing condition, etc. Thus, a cow weighing 1000 pounds and giving 25 pounds of average milk, - that is, with an average amount of butter fat in it (about 4 per cent), - needs daily I. 85 pounds of digestible protein and I 3.4 pounds of digestible fuel, or about seren times as much fuel as protein.

Young, growing animals need more protein in proportion than do mature animals. In the early stages of the fattening process more protein is needed than in the later stages after sufficient bone and muscle have been formed and all that remains is to put on fat. Cows giving milk need more protein than dry cows.

Importance of variety in food. From the facts given above it is clear that it is important to feed a considerable variety of materials in order to insure that all the kinds of nutriment required are provided. Animals grow tired of a ration that is fed a long time without change, unless by chance it should contain everything needed in the correct proportion. This is nature's way of insuring proper nutrition. When animals are allowed to choose from a large variety of feeding stuffs, they will naturally choose those that contain just what they need unless for some reason their appetites have been made abnormal. Nilk is the only food that contains everything the animal body requires and in the right proportion. Few, if any, other feeding stuffs contain all the seventeen or eighteen protein combinations required. Hence the necessity of feeding a variety of materials, and of changing the ration occasionally. Such changes 
should, of course, be made gradually, for sudden changes are likely to cause disorders of the digestive organs, for one reason, because animals are likely to eat the new ration too greedily. This is especially true when the new ration happens to contain the nutrients lacking in the old.

Classes of animals likely to need minerals. Horses, cattle, and sheep ordinarily get all the minerals they need in the coarse forage (hay, fodder, etc.) which they consume. These minerals are fairly abundant in the leafy portions of plants. But hogs and poultry consume relatively small quantities of leaves. The seeds on which they mostly feed are deficient in minerals. Wood ashes and ground raw bone are valuable additions to the ration in feeding hogs. Ground raw bone and oyster shells are valuable for poultry.

Classes of feedstuffs. Feedstuffs may be divided into two general classes; namely, roughage and concentrates. Roughage consists of bulky feeds like hay, corn fodder, straw, etc. Concentrates consist of grains and such mill products as bran, oil meal, gluten, etc. Generally speaking, the concentrates contain both more protein and more fuel than roughage. Shelled corn contains about 8 per cent of digestible protein and 76 per cent of digestible fuel. Timothy hay contains 3 per cent of digestible protein and 44 per cent of digestible fuel.

There is wide variation in the composition of both roughage and concentrates. In general, hay made from legumes, such as clover, alfalfa, cowpeas, etc., is much richer in protein than hay made from the true 
grasses, such as timothy, millet, Johnson grass, and the like. Certain mill products among the concentrates are extremely rich in protein. Cottonseed meal contains about 37 per cent, linseed oil meal about 27 per cent, and wheat bran about 12 per cent of digestible protein.

Except in the West, where the principal hay is alfalfa, the common feeding stuffs raised on the farm usually contain rather too little protein, so that it is frequently necessary to buy mill products to enrich the ration in this class of nutrients. With plenty of good leguminous hay the amount of mill products required for this purpose is less than when only grass hay is available.

Cows and sheep require large amounts of roughage in addition to plenty of concentrates. Their stomachs are so large that the bulky roughage is needed to fill them out and excite active secretion of digestive fluids. If fed concentrates alone, they are liable to get indigestion. Horses, when at hard work, require only about half as much roughage with a given amount of concentrates as do cows, because the stomachs of horses are smaller. Hogs and chickens have small stomachs and require a larger proportion of concentrates. Both horses and cattle, when idle, and when not growing or being fattened, can be properly nourished on roughage alone if it is of good quality, but under other conditions require grain. Good pasture is so palatable and so easily digested that nearly all kinds of animals can eat enough of it to furnish them abundant nourishment. 


\section{Farm Science}

\section{Class Exercise}

List the rations fed all kinds of stock on near-by farms. Make a list of the feeding stuffs grown, and of those bought. Estimate as nearly as possible the quantity of each feeding stuff required by each kind of animal for a year, or for a feeding period in case of fattening animals. Find what it costs to feed an animal a year. 


\section{IART FOUR - THE FARM}

\section{CHAPTER EIGHTEEN}

\section{THE FARM BUSINESS}

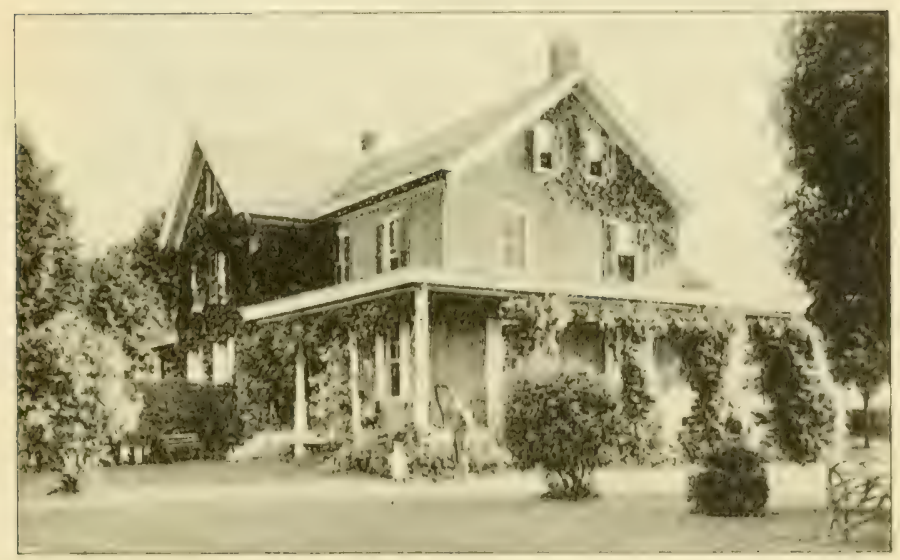

lig. 140. An attractive country home.

I Faku is a place devoted for the comblued of at husiness batsed on the production of cropse for humatu forml. for feeding livestock, or for use in making clothing or other manufactured products.

How farming differs from other kinds of business. A farm is not only a plate for the comeluet of a lusiness; it is alse a home. This is not erencrally true of wher businesies. Fow businesses other than farminer have: such a home connecter with them as the one show'm in Figure 1 fo. The farm lusiness is such that some one: must be on hand day and night to lowk after it. The 
farm animals must be fed and watered and kept out of mischief and danger. The growing crops must be protected against stock running loose. Both crops and animals, as well as the farm machinery, must be guarded against theft. A city business is usually large enough to afford to employ some one to watch the premises at night, or is under the protection of the police. On the farm it is the people who do the work on the place who must do these things.

Even if caretakers were not needed on the farm, if those who do the farm work did not live on the farm they would lose much time in going to and from work, for there are usually no street cars in the country as there are in cities.

The primary business of the farm. The primary business of the farm is to produce what those living on the farm require for their living. When the country was new, and there were no railroads, most farms produced not only the food of the people who lived on them and the feed of the animals kept on them, but also the material for the clothing of the farm family and the hired help. With the development of railroads and other means of transportation the necessity for the production of everything needed on the farm became less urgent. Farmers could then devote more of their energies to the production of things for sale and use the money thus obtained for supplying things which formerly had to be produced at home.

Advantages of producing home supplies. Many farmers grow no garden, produce no fruit, and keep no animals for producing the meat and milk needed on the 


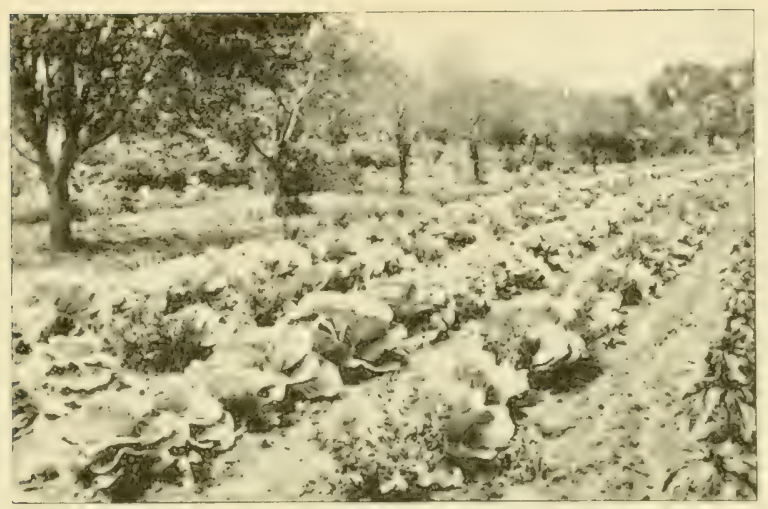

FIG. I.7. Every farm should have a vegetable garden and an orchard.

farm. Instead they raise cotton, wheat, and other products for sale and depend on buying what they need. They claim they can sell cotton or wheat and buy butter, eggs, regetables, and fruits more cheaply than they can raise them. Possibly in some cases this is true. But the fact remains that when an abundance of fruit, vegetables, eggrs, etc., are produced on the farm, the firm family will have more of them to eat than is the case where these things must be bought. Not only that, but what they eat will be of better quality than when it is bought at the store. The standard of living on the farm corresponds very closely to the proportion of the food needed by the farm family that is supplied directly by the farm. The famer whose orchard and garclen are shown in Figure if $\mathrm{I}$ has table luxuries for which few farmers, no matter how profitable their business, will spend their good money. 
Secondary business of the farm. After producing what farm products are needed on the farm, or producing things to be sold for the purpose of buying necessary things, the farm should produce things for sale in order that the farmer may have money with which to provide suitable education for his children, and provide his family with something more than the bare necessities of life. The farmer should also be able to lay by something for his children, and to take care of himself and his wife in their old age. It is fortunate when the income from the farm business is large enough to enable the owner to give each of his children a comfortable home as they reach maturity and start out in business for themselves.

Why some farm products do not sell readily. Miany years ago there was a farm located near a village of about a thousand people. There was a six-acre orchard and always an acre or more of garden on this farm. Usually there were more apples, potatoes, cabbages, onions, etc., than the farm family could consume, and the farmer would take the surplus to town and try to sell it. Usually he found the stores full of such things, and the merchants would not buy any more. He used to think it was mere meanness on the part of the merchants that made them refuse to buy his fruits and regetables; they bought his wheat, corn, butter, eggs, and hogs readily enough. The merchants did not seem to care how much good food material went to waste on near-by farms.

But this was not entirely the fault of the merchants. True, they could have developed the business of shipping 
perishable farm produce to large cities near by, but even then there would have been times when the markets even in these large cities were glutted with such things, so that shipments would not have sold for enough to pay the freight. The trouble was due to a different cause, as we shall see.

Quantity of fruits and vegetables needed. Eighty acres of orchard, 40 acres of potatoes, and 30 acres of other regetables will produce all the fruits and vegetables needed by a village of rooo people. Many people in such villages grow a good part of their own fruits and regetables, so that the amount they need to buy from farmers in the surrounding country can be produced on less acreage than that given above.

If the farms surrounding the village average 160 acres in size, there would be 4 farms to the square mile. Within a radius of 7 miles of the village there would thus be about 600 farms. If the number of people on these farms averages 5, the total population to be fed, both in town and country, would be 4000 . This would require 320 acres of all kinds of fruit, I60 acres of potatoes, and $\mathrm{I} 20$ acres of all other vegetables, with average yields. This would be an average for each farm of about $\frac{1}{2}$ acre of fruit, $\frac{1}{4}$ acre of potatoes, and $\frac{1}{5}$ acre of all other vegetables. It is easily seen that in a year of good crops, when each farm had acreages of fruits and regetables such as the farm mentioned above, there would be more of these perishable products than the community could possibly consume. Nor could a large city begin to consume the surplus of such products produced in the territory tributary to it. 
If the farmer cannot sell just anything of which he happens to produce a surplus, it should be helpful for us to consider briefly what he should produce for sale.

\section{WHAT CROPS THE FARIIER SHOLLD GROW}

Crops the farmer does grow. When we remember that most farmers experiment more or less with nearly all kinds of crops that can be grown in their region, we ought to be able to learn something of value by studying for a moment those crops that farmers generally have decided on as best for their conditions. The data in the following table show what the combined judgment of the farmers of this country has led them to grow. The figures relate to the census year I9og.

\begin{tabular}{|c|c|c|c|c|c|c|c|}
\hline \multicolumn{3}{|c|}{ CROPS } & & ACRES & CROPS & & ACRES \\
\hline Corn. & & & & $9 S_{3}, S_{2}, 66_{5}$ & Kafir and milo & & $\mathrm{I}, 635, \mathrm{I} 53$ \\
\hline Hay . & . & & . & $68,246,344$ & Peas . . & & 1,305 \\
\hline Theat & . & & . & 2,592 & Tobacco & & \\
\hline Oats . & - & & . & 35, I $59,44 \mathrm{I}$ & Fruits. & & $\infty \infty^{1}$ \\
\hline on & . & & . & 8 & itoes & & 3,6 \\
\hline Barley & . & & • & 06 & $t$ potatoes & & \\
\hline Coarse $\mathrm{f}$ & orage & . & . & $4,034,432$ & Other vegetable & & $2,763,269$ \\
\hline Rye & & & & $2,105,65 \mathrm{I}$ & All others . & & $6.577,560^{2}$ \\
\hline Flax & . & & & $2,110,517$ & Total & & $316,630,288$ \\
\hline
\end{tabular}

From the figures above it is clear that farmers, taking the country as a whole, have decided that the crops of which they should grow most are corn, hay, wheat, oats, and cotton. No other crop comes anywhere near these in acreage. Fruits occupy only about 2 per cent of our total crop area, potatoes about I per cent, and ${ }^{1}$ Bearing trees only. $\quad{ }^{2}$ Includes non-bearing fruit trees. 


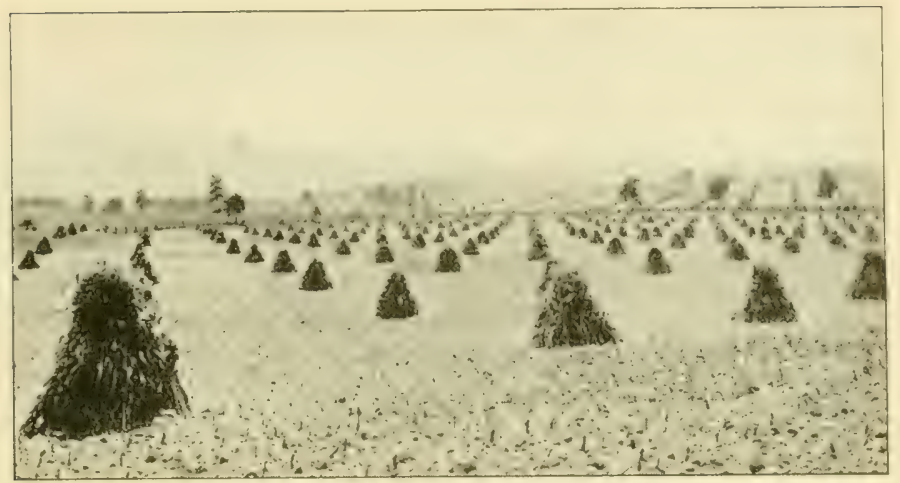

Fig. If2. Vireninia cornfields. Eastern corn growers cut their corn fur fuelder

other vegetables a little less than I per cent. The number of farmers who can devote all or a major portion of their land to any crop) other than corn, hay, wheat, oats, and cotton is relatively small.

Very little corn is grown in this country north of a line connecting those points that have a mean summer temperature of 66 degrees. This line passes through northern Wisconsin and northern Michigan. On the west, corn practically stops at the line connecting points having an average summer rainfall of $S$ inches. ITest of this the nights are too cool for this crop). The S-inch summer rainfall line runs north and south about the longitude of the western border of Kansas. Very little corn is grown west of this line. The real corn belt extends from Virginia and Maryland to Kansas and Nebraska. Figure I $_{2}$ shows a scene in a portion of Virginia where corn is the leading crop). In the eastern part of the corn belt nearly all the corn is cut for fodder. In the western part much of it is husked from the stalk. 


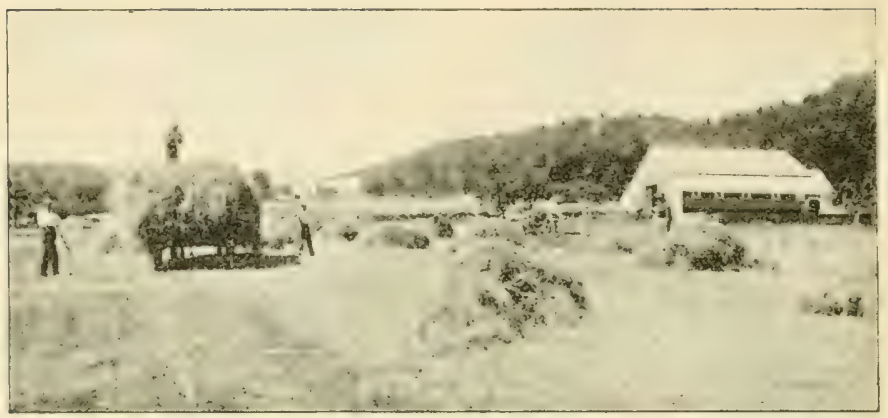

FIG. I43. Haying in the state of Maine. Next to corn, hay occupies the largest acreage of any crop on American farms.

Next to corn, hay occupies the largest acreage of any crop in this country. While it is grown all over the country more or less, it occupies the largest relative acreage in the Northeastern and Northern states and in the Mountain states. Many different crops are grown for hay. Timothy and clover mixed occupies the largest area. This mixture is found mostly in the Northern and Northeastern states. Figure I +3 shows a typical haying scene in Maine, where timothy and clover constitute the principal hay crop. In the Mest. alfalfa is the principal crop grown for hay. In the South no one crop stands out as the principal source of hay, but compeas, Johnson grass, bermucla, and in some localities alfalfa, are the most important.

Wheat occupies the third largest acreage. It is gromn mainly in the North and West. Figure Itt shows a fine field of wheat in the state of Michigan. About two thirds of our wheat crop is fall sown and one third spring sown. The line between the fall and spring wheat 


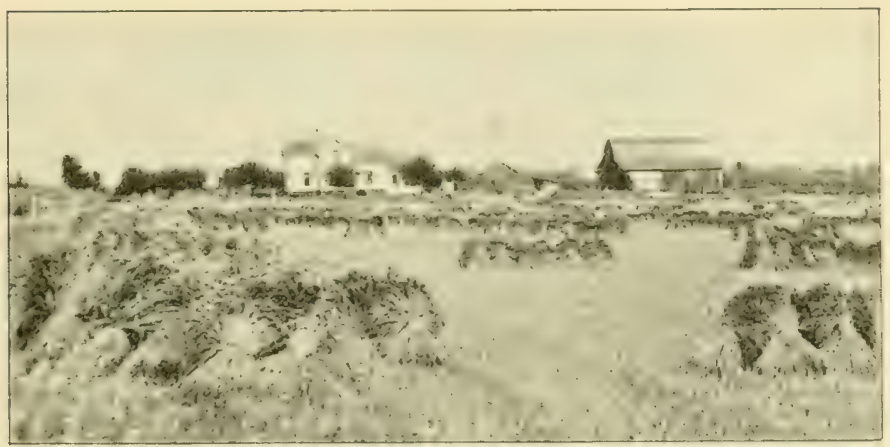

Fig. If4. Wheat, the worlil's greatest bread crop, and the third crop in acreage in the United States.

areas runs northeast and southwest about through Sioux City, Iowa. Little spring wheat is som south of this line and little fall wheat north of it except in the far West. On the Pacific coast wheat is sown indifferently in fall or spring. Real winter wheat will not head out until it has been through a winter. Hence in localities where wheat is sown in either fall or spring the varicties grown are mostly spring wheats. When sown in the fall, these frequently winter kill badly.

The fourth crop in point of acreage is oats. They are grown mostly in the Northern states. A Pennsylvania oatfield is shown in Figure 145 . Oats are the principal grain crop of the South, though the area gromen there is much less than it is in the North. This crop) is usually sown in the fall in the South. In midille latitudes, - that is 10 say, in a strip of country extending from about Washington, I).C. to Kansas City. Missouri, - oats are not a satisfactory crop). This is too far north for fall sowing, and it is so far south that the spring- 


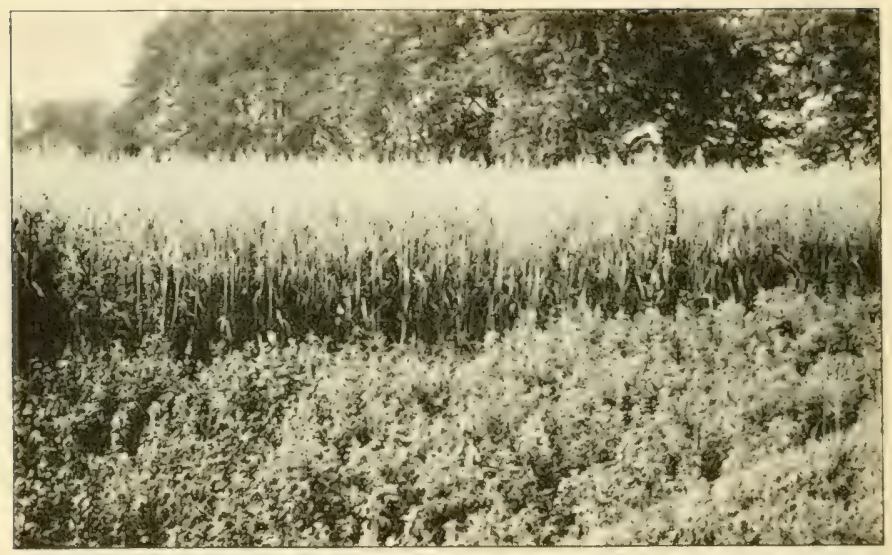

FIG. I45. Oats, with young alfalfa in the foreground.

sown crop, being late in maturing, often fails because of attacks of rust when warm weather comes. The region to the north of this may be called the spring oats region, while that to the south may be called the winter oats region.

Cotton is the fifth, and the only remaining, crop that occupies a large acreage in this country. It is the great money crop of the South. It grows about as far north as the southern line of Missouri. Figure $I_{4} 6$ shows a typical cotton-picking scene in South Carolina. If a machine could be devised for picking cotton, it would work a wonderful revolution in the agriculture of the South. At present the amount of cotton a family can grow is limited by what they can pick, which is about seven bales for the average family. This makes a very small income for a farm family. With a mechanical picker that would remove this handicap a family could 


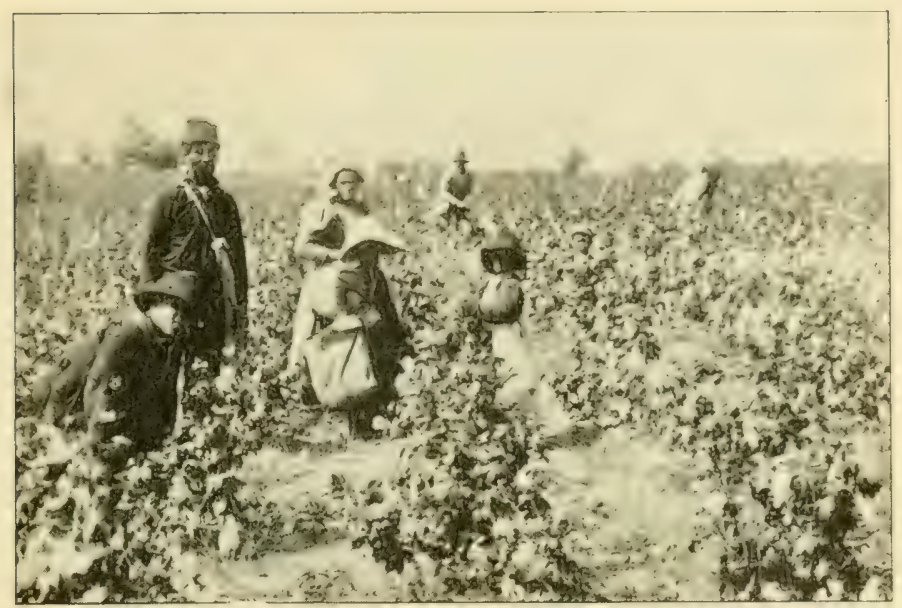

Fic. 146. Cotton, the world's greatest fiber crop; the fifth in acreage in this country.

grow thirty or forty bales easily. This would do away with the one-horse farming of the South, and convert it into a region of rich and prosperous farmers, whereas now most of the people who actually do the work in the cotton fields are very poor.

No other crop occupies sufficient acreage in this country to justify particular notice here.

Conditions under which a farm may properly depend on fruits and vegetables for its principal income. In the vicinity of every town or village there may be a few farms devoted largely to the production of fruits and regetables to supply those living in town. We have already seen that a very few such farms will supply a town of considerable size.

Near large cities the number of such farms that may 


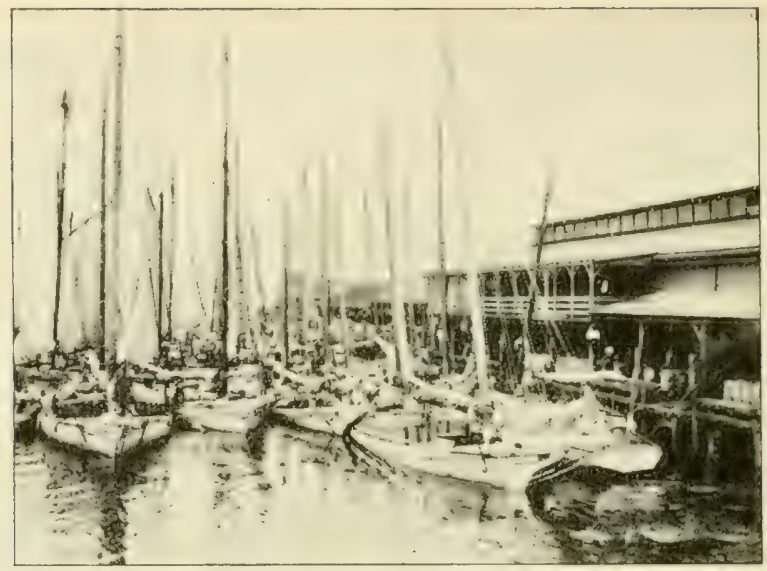

FIG. 147. Loading early potatoes, Chesapeake Bay; grown in the famous trucking region on the Eastern Shore of Maryland and Virginia.

do a profitable business is larger, in proportion to the size of the city.

If a locality, even at a distance from any large city, has a sandy soil on which vegetables can be matured much earlier than on the surrounding heavier soils, and if there are not too many such sandy areas within market distance of the same market centers, then that locality may find it quite profitable to engage largely in truck farming (that is, the growing of vegetables for shipping to a distant market). Muscatine County, Iowa, is a case in point. In the Mississippi River bottom near the town of Muscatine, there is an extensive area of sandy soil devoted largely to growing regetables and melons for city markets in the central West. There are, however, localities where there is so much 
soil of this character that it cannot all be used in this manner. The Eastern Shore of Maryland and Tirginia grows enormous quantities of potatoes and other vegetables for the markets of Baltimore, Philarlelphia, and New York. (See Figure I+7.) But there are great stretches of sandy soil in southern New Jersey lying idle today because there are not markets enough to consume all the regetables that could be grown on them, and they are not well adapted to corn, hay, wheat, and oats.

Farms situated near the coast of the Gulf of Mexico, if they are near a good line of railroad, may be deroted largely to regetables. (See Figure I 4 S.) These crops may be matured down there before the North begins to send her vegetables to market. But many of the farmers who have undertaken this kind of business have failed because some years so many regetables are produced that the markets are glutter and prices fall below

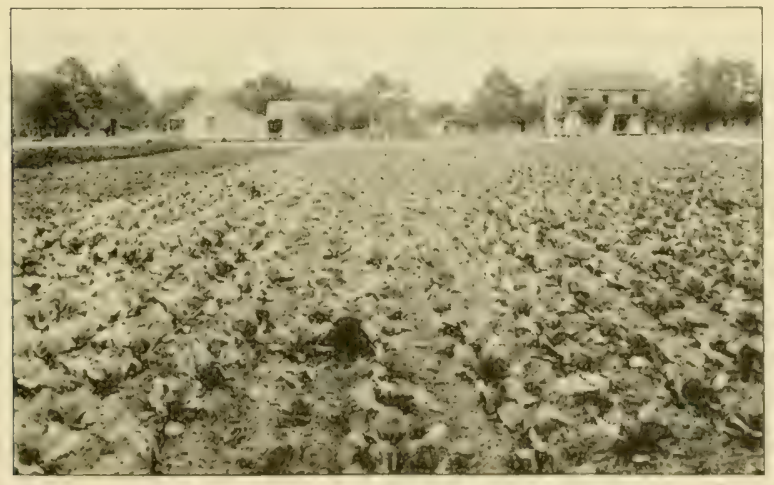

Horlicullural Investigations, U.S. D.A.

FIG. r48. 'Truck farming in Florida. 
the cost of shipping. Vegetable growers in the South who devote most of their land to staple crops like corn, hay, cotton, etc., can stand these occasional losses on their vegetable crops, and in the long run they make money: The chance of success in growing regretables at long distances from market is greatly improved when the growers form coöperative associations and market their regetables together. In this way they can obtain hetter shipping facilities, and can maintain agents in the great market centers to look after the sale of their products.

Certain localities are better adapted to the production of certain kinds of fruits than are most other localities. In some instances enormous businesses have grown up, based primarily on fruit production. At Puyallup (pronounced Pyu-ăl'up), Washington, where the soil and climate are especially adapted to all kinds of berries, millions of dollars' worth of berries are grown annually. These berries are shipped as far east as St. Paul, Minnesota. A strong marketing association has made this business possible. Several other localitics in western Washington and western Oregon are similarly developed as centers of berry production. Figure it9 shows a field of berries at Woodburn. Oregon, where one of these associations exists. At Wenatche, Washington, and in other locations in both Oregon and Washington, the production of apples has been similarly developed. But a few years ago so many apple trees were planted in this country that more apples were produced than could be sold, and many growers who had nothing but apples for sale lost their farms. This is a danger with 


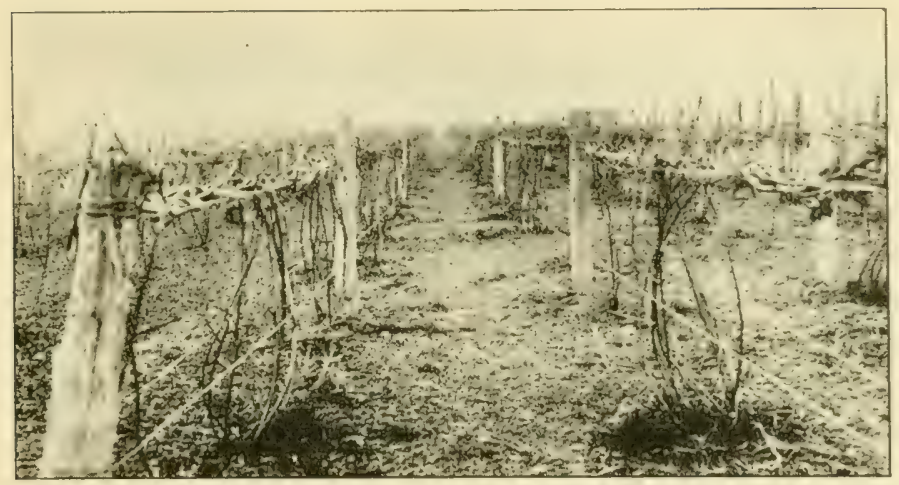

Uince of Farm Hanagement (D. A. Brofic)

Frg. I49. Field of berries near WVodburn, Oregon.

which the fruit grower always has to contend. If fruits were grown only on farms that are devoted largely to other crops, the business would be much safer.

Choice of staple crops. Crops like corn, wheat, oats, hay, and cotten are called slaple, because their products may be kept many months without decaying, while fruits and vegetables are called perishable crops, because their products, generally speaking, cannot well be kept in their fresh condition for any considerable length of time.

We have already seen that by far the greater part of the farm land in this country is deroted to staple crops. and this is necessarily so. The particular staples to be grown on any given farm depend mainly on its location. Climate is one of the deciding factors in all cases. The soil has much to do with the choice of crops in many localities. But when both climate and soil are farorable, the most important consideration then becomes the 
possibility of selling the product at a profit. Generally speaking, the farmer will choose those crops that bring him the largest returns. But there are exceptions to this, some of which are dealt with in the following paragraphs.

Needs of the farm for feed. While cotton may bring by far the largest income to the farmer, the cotton farm must keep work animals, and it should also produce the food of those living on the farm. Hence good farmers, even where cotton is much more profitable than any other crop, derote part of their land to corn, oats, hay, etc., for feed, and to fruits and regetables for food. Similarly, in parts of central Illinois where corn is the most profitable crop farmers generally grow considerable areas of oats to feed their work stock. They put part of their land in clover, not only as a feed for stock, but as a means of keeping up the fertility of the soil. They also raise fruits and garden vegetables for home use.

Seasonal distribution of labor. A single crop, no matter how profitable, almost never furnishes the farmer employment constantly throughout the season. If another crop can be found, the labor on which does not interfere with that on the more profitable crop, it will usually add to the farm profits to grow some of the less profitable crop. It may pay to grow at least small areas of crops that if grown on larger areas would not pay at all. This is one reason why it pays the cotton farmer to grow his own hay and grain. He can usually do so without decreasing the area of cotton he is able to care for.

In regions where corn and wheat are the most profitable crops, as is the case over much of Kentucky, Ten- 
nessee, Missouri, and parts of Illinois and Arkansas, at farmer who has no labor except his own can grow just about as much corn along with all the wheat he can grow as he could if he sowed no wheat. The corn crop) keeps him busy from early spring till harvest time, and again in the fall after the wheat is sown. The wheat crop gives him something to do the rest of the summer. Hence, even if the price of wheat is so low that it would not pay by itself, it may still add considerably to the income on a farm that grows all the corn the available labor can manage.

Needs of the soil. In regions where some one crop is distinctly more profitable than any other, especially if that crop is a cultivated one like corn, cotton, tobacco, etc., the continued cultivation of the one most profitable crop may lead to exhaustion of the soil. This has happened in many parts of the South, and in parts of the corn belt as well. In such regions crops are often grown as green manures. Methods of dealing with this problem have already been discussed in the section on Soils.

Presence of productive livestock. When animals are kept for the purpose of deriving income from their sale. or the sale of their products, they are termed productive stock, as distinguished from work stock. A farm that is well stocked with productive livestock will naturally choose some of its crops with special reference to their value as feed for these animals. (See Frontispiece.) The proportion of the farm to be kept in pasture is determined by the needs of the farm animals. It seldom pays to grow only feed for stock, though there are localities where this is the best practice. 


\section{SPECIALIZED VERST'S GENERAL FARMING}

Some of the most important decisions the farmer is called upon to make are what crops he shall grow, what acreage of each, and what livestock he shall keep. His success as a farmer depends largely on how he decides these questions. Generally speaking, the safest course is to follow the example of the most successful farmers in the neighborhood. But one should carefully distinguish between those successful farmers who are following some unusual type of farming, and those who follow the type of farming most common in the locality. Oftentimes a man's success depends on the fact that few others are doing what he does. Thus, a certain farmer in one of the Southern states made a very profitable business by growing nothing but hay for sale. His success was due to the fact that his neighbors did not grow enough hay to supply their needs. If all these neighbors had gone into the business of growing hay, they would not have been able to find a market for it.

Another Southern farmer found the business of growing pigs for sale to his neighbors very profitable. The region was one, where it did not pay farmers generally to keep hogs except for producing the home supply of meat. The amount of this required was so small that few farmers kept a brood sow. Instead they depended on buying pigs from this neighbor. Again, his success was due to the fact that he was the only farmer in the neighborhood who followed this business.

As a rule, when the farmers in a locality depend on buying some kind of farm product that could easily be 
produced locally, it will pay one or more local farmers to produce enough of this product to supply the local demand.

In a farm-management survey in one of the Central states, there were found two very profitable dairy farms. They both supplied milk to a near-by town. Two other farmers had undertaken the dairy business, but had to dispose of their product in a different way, for the town was already supplied. These two dairymen were doing poorly.

When the locality is adapted to it, and when the farmer himself is of the right type, specializing in farming usually pays better than general farming. An instance was found in a Western state, where the farmers generally grew wheat, corn, a little hay, and frequently an acre or two of strawberries. The livestock usually consisted of a few cows and a brood sow or two, in addition to the work stock. In this locality there was one farmer who had his whole farm in berries of different kinds. He made the most profit of any farmer in the community. But another farmer who had about the same acreage of the same kinds of berries lost money. He was not adapted to the specialty he had undertaken. Relatively few men can make a success of any unusual type of farming. It is far safer for the arerage man to follow the type which has given best results on the largest number of farms in his locality.

\section{Class Exercises}

By interviewing the farmers in the neighborhood of the school, get as complete a record as possible of the acreage of 


\section{4}

\section{Farm Science}

every crop grown on every farm. In the case of vegetables grown for home use, it is hardly feasible to get the acreage of each kind of vegetable separately; the entire acreage of such crops may be reported as "garden." Find what percentage the area of each crop is of the total crop acreage of cach farm. By adding logether the area of each crop on the various farms, find the total acreage of each crop on all the farms, and then convert these acreages into percentages. How does the percentage area of each of the crops compare with the percentage acreage of the same crop for the entire country? The latter percentages may be obtained by dividing the area of each crop in the table on page 2 ; 0 by the total at the bottom of the table.

What is the average area of farm garden and of fruit per farm in the community? What is the crop area per work horse on each of the farms? On all the farms?

Iithat proportion of each of the more important crops is sold, fed on the farm, or used for seed on each farm? On all the farms taken together? 


\section{CHAPTER NINETEEN}

\section{HOW TO SECURE BEST RESULTS FROM GROWING CROPS}

THE farmer's problem in crop growing is to secure the largest yields he can without too much expense. By using a great deal of labor in preparing the soil for planting, by very thorough tillage, and by the use of large quantities of manure and fertilizers it is usually possible to get enormous yields of any crop, provided of course that the work is done intelligently. But it does not always pay to do this. The use of a few tons of manure to the acre may pay a handsome profit, but it does not follow that doubling the quantity of manure will double the profit. The farmer must therefore use judgment in his work.

There are several ways of increasing the yield of crops. some of which cost very little and should therefore be used to the limit. Others cost money, and the farmer should observe closely the effect they have in order to know how far to go with them.

Conditions required for big yields. The more important conditions that must be met in order to secure large yields are as follows :

The crop planted must be of a kind and variety known to do well in the climate of the region, and to be adapted to the particular kind of soil in which it is to be planted. It is not always easy to find out what varicties are best adapted to local conditions, but when this is once known it costs very little to get a start of them. In order to be protitable the cropes to be grown must also be adapted to local market conditions. 'That is, 
there must be a ready sale for them, unless they are to be used on the farm.

The seed used should be of good vitality and germinating power, and should not be mixed with weed seeds. The right amount of seed per acre must be planted, and the spacing of the plants must be such as to give the individual plants opportunity to develop normally.

The seed must be planted at the proper depth. This varies with the kind of seed and the character of the soil. Seeds should be planted deeper in sandy soil than in a heavy soil. The general rule is to plant each kind of seed just deep enough so that the store of plant food in the seed may support the young plant abundantly while it is coming up and getting its first leaves and roots. If planted too deep this supply of food may all be used up in producing a stem long enough to reach the surface of the soil. If planted too shallow the soil may dry out around the seed before it is well started. Generally speaking, the larger the seed the deeper it should be planted, since this will give the greater amount of moisture to the larger kinds of seed.

The soil should be well supplied with moisture, but not so full of it as to exclude air, for germinating seeds use a large amount of oxygen from the air.

The soil should also be warm enough to insure prompt germination of the seed. The temperature at which different kinds of seed will germinate varies considerably. Wheat and oats will germinate when the temperature of the soil about them is as low as 40 degrees, while corn requires a temperature of about 50 degrees. If 


\section{Securing Best Results from Growing Crops $28_{7}$}

planted before the soil is sufficiently warm, the seed will rot, for there are bacteria and molds that can grow when the temperature is very little above freezing.

The soil must be abundantly supplied with humus, or decaying organic matter. The reasons for this have already been given in the discussion of the soil. The largest yields of crops cannot be obtained without plenty of humus.

An abundance of all the necessary kinds of plant food must be present in the soil.

The soil must be put in the very best condition of tilth before the seed is planted. Some plants are more particular about this than others. By good condition of tilth is meant that the soil must be well pulverized, but not reduced to an actual powder. It must be free from large clods. In short, the soil must be in condition to hold a large amount of moisture and a large amount of air at the same time, and it must be fine enough to enable the seed to touch a large number of soil grains so as to get moisture and plant food from them. The soil must also be loose enough some distance down to permit plant roots to thread their way through it easily, but not loose enough to have large open spaces in it. (See Figure 34, page 67.)

The surface soil should not be allowed to bake, or form a crust, for this tends to prevent free circulation of air in the soil. It also causes much of the water that falls as rain to run off over the surface and thus be lost.

The soil must be kept free from weeds, for weeds soak up enormous quantities of water from the soil and use large amounts of available plant food that is needed by 
the growing crop. The roots of some weeds also cxude juices into the soil that hinder the growth of crops.

Relation of yield per acre to profit. The relation between yield of crops per acre and the profit made by the farmer (on his entire farm) was determined for a group of $37 \mathrm{~S}$ farms in Pennsylvania. The average vield of the crops on a farm was expressed as percentage of the average for all the farms. Thus, if the average for a given farm is 86 per cent of that for all, then the yield on that farm is expressed as 86 . The profits made by each farmer were expressed in percentage of the arerage profits of all farms of the same size. When expressed in this manner the relation between yields and profits were as shown in the following table:

\begin{tabular}{|c|c|c|c|c|c|c|}
\hline YIELDS & & & & & & Profits \\
\hline 84 and less & - & - & - & - & & 49 \\
\hline $8_{5}$ to 99. & . & . & . & - & & 74 \\
\hline IOO to II 4 & . & . & . & . & & 108 \\
\hline I I 5 to I $_{39}$ & . & . & . & . & & I 53 \\
\hline I 40 and over & & & . & & . & \\
\hline
\end{tabular}

From this it appears that profits increased as yield per acre increased, till yields about 40 per cent above the average of the community were reached. Those whose vields were greater than this did not make so much profit. But the table shows very strikingly that with the methods used by these farmers it pays handsomely to get yields considerably above the average. Those whose yields were more than 40 per cent above the average evidently used too much manure or fertilizer, or did more work on their crops than was profitable. 
Relation of prices to the most profitable yields. When the price of a crop product is very high, it pays to use more manure and fertilizer and to put more work on the crop than when prices are low. Suppose, for instance, that after the usual amount of fertilizer has been applied to an acre of cotton, the addition of another hundred pounds, costing $S_{1.50}$, would increase the yield by ro pounds of lint. Now if the lint were worth iS cents a pound, the increase in crop value would be Sr.So, which would make the additional hundred pounds of fertilizer profitable. But if lint were worth only io cents a pound, the increase in value would be only $\mathrm{S}_{\mathrm{r}}$, which is less than the cost of the additional fertilizer.

Similarly, when the crop product is high priced it may pay to grow the crop on land not well suited to it. while if the price were low it might not pay. Suppose. for instance, that a given field, with ordinary methods, will produce 20 bushels of corn per acre, at a total cost of Si2. With corn at 50 cents a bushel this would be a losing proposition, while with corn at So cents there would be a profit of $S_{4}$ per acre. In the South, when cotton is high priced much land is devoted to this crop) that is either left idle or devoted to other crops when cotton is low priced. High prices thus tend to reduce themselves by increasing production, while low prices tend to decrease production and thus raise prices.

For a similar reason it pays to use more fertilizer and more labor when these (fertilizer or labor) are cheap) than when they are high priced.

When the price of farm products is high the farmer is justified in using every means at his command to increase 


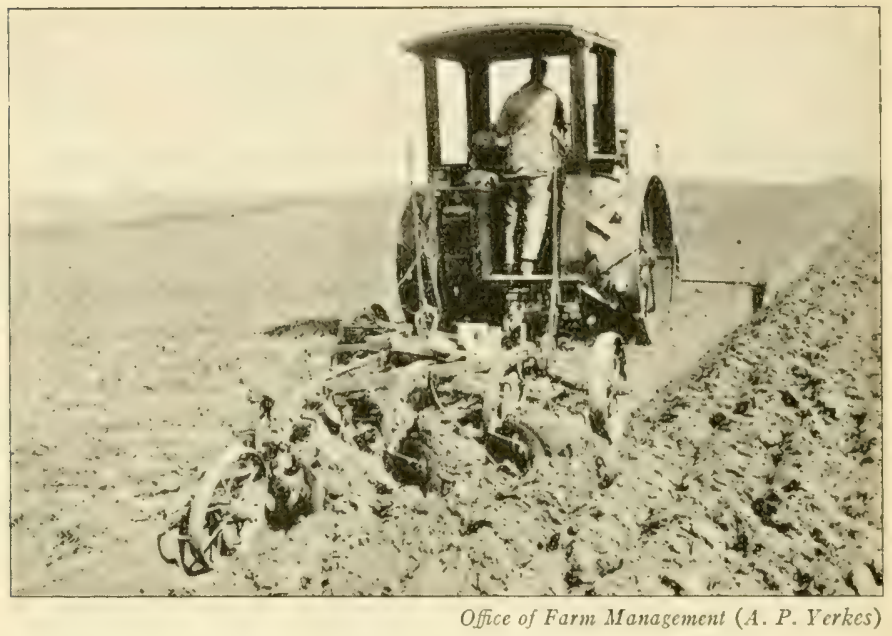

Fig. I50. Tractors pay on large farms, especially when farm products are high priced. Small farms cannot afford such expensive equipment.

the yield of his crops, even if some of these means are expensive (Fig. I 50). But when prices are low he should confine himself more largely to the less expensive means of increasing yields.

\section{SELECTION AND CARE OF SEED}

One of the ways by which farmers can increase the yield of their crops is by the use of the best seed obtainable. Increased yields obtained in this manner usually cost less than those obtained by any other means. In most cases good seed can be secured by a little extra work on the part of the farmer, and if this work can be done when other work is not pressing there is really no cost to it at all. 


\section{Securing Best Results from Growing Crops 29I}

Seed of the small grains. The main consideration in the case of seed wheat, seed oats, and the seed of other small grain crops is plumpness and freedom from admixture with weed seeds. In some localities wheat is more or less mixed with cheat, and sometimes with rye. Cheat decreases the yield and lowers the price of the grain, and rye also causes the wheat to sell for less than clean wheat would bring. Wheat does not turn to cheat, as so many people believe. Cheat comes from cheat seed. Wheat can be cleaned of cheat by running it through a good fanning mill a time or two. If no cheat seed is sown, and there is none in the ground, there will be no cheat in the crop. Cheat ripens a little earlier than wheat, and drops part of its seed before the wheat is harvested. The next year the percentage of cheat in the wheat grown on this same field is much larger, even if no cheat seed is sown. It is this fact that has led so many farmers to think that wheat turns to cheat.

About the best way to get rid of rye when it is mixed with wheat is to pull the rye out of enough wheat for seed sometime before harvest, but after the crop has reached its full growth. Rye grows a foot taller than wheat, and can thus easily be removed. Before threshing this clean wheat it is a good plan to run some straw through the threshing machine. This will clean out all or nearly all the rye grains in the machine and thus prevent the clean seed from becoming mixed with rye again. When there is only a little rye in a field, it may all be removed by hand. If there is rye on neighboring farms, some straw should be run through the threshing machine 
as soon as it starts work on the farm; or the first few sacks of wheat, which will contain all the rye the machine brought to the farm with it, may be kept separate and not used for seed.

Since wheat is self-fertilized, one way of getting perfect uniformity in the wheat on a farm is to pick out a single very fine plant and save its seed by itself. Plant this the next year in a small patch by itself, and thresh it out by hand. Repeat this till there is enough to sow an acre or more, which may be handled in the usual way, but should be carefully guarded against mixture with other wheat. The next year a whole field of wheat can be sown from this beginning, and the field will be all of a perfectly uniform type. Such wheat, if of a really good type, can usually be sold for seed at a price that will pay for the trouble taken with it. Oats may be handled in the same way.

Saving seed corn. The corn plant is large enough to permit work with individual plants, and experience has amply demonstrated that it pays to select seed corn in the field after the crop is ripe but before it is harvested rather than from the crib in the spring just before planting time. Seed corn properly selected and cared for will give yields to to 20 per cent greater than that taken from the crib in the usual manner.

In selecting seed corn, look first at the stalk. This should be not too tall, and not slender. Reject a goodlooking stalk if it has more room than usual, for its excellence may be due to lack of competition. If the stalk is satisfactory, then look to the ear. This should be large and sound, with a good covering of 


\section{Securing Best Results from Growing Crops 203}

husk, and should be quite dry. If not dry by this time, it is a late strain and not desirable. The best ears usually hang over more or less because of their weight. There is also the advantage in a recurved ear that rain does not enter the husk and spoil the grain. The ear should be attached to the stalk by a shank of medium thickness and length.

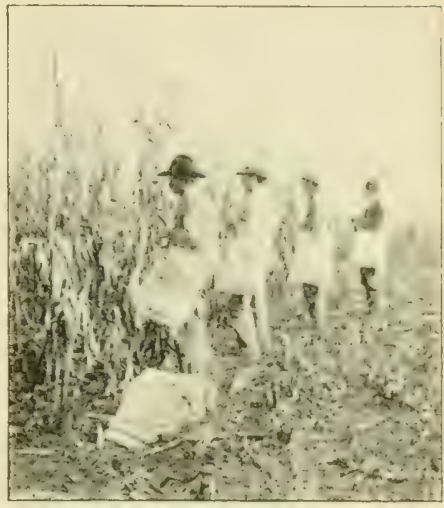

Corn Intestigatians, U.S. D.A.

FIG. I5I. Gathering seed corn.

A sack with one bottom and one top corner tied to a cord and slung over the shoulder makes a good receptacle for the seed corn as it is husked. The sack may be emptied on the ground at the end of the row and the corn later taken to the place where it is to be stored. (See Figure I $_{51 .}$.)

There is considerable advantage. especially where corn is to be planted with a planter, in having the rows of grain straight on the cob of seed ears, and the grains of uniform size, so that they will feed through the planter without skips. This gives a better stand of corn the next year.

The seed corn gathered each day should be hung up in a dry place the same day, in such manner that no two ears touch each other. A very good plan is that shown in Figure 152. After the ears are in position, they are hung in a dry place where they will not freeze before 


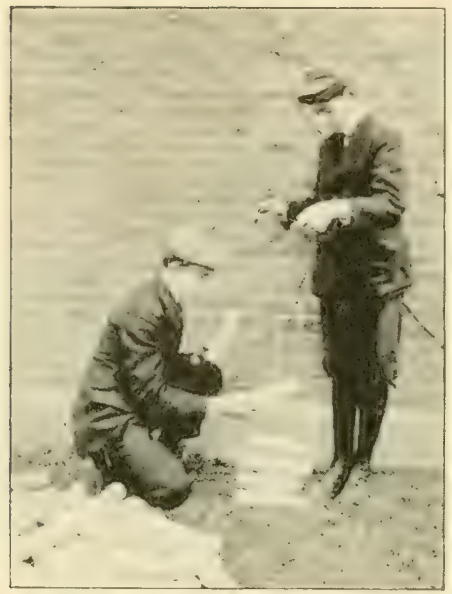

Corn Investigations, U. S. D.A.

FIG. 152. Stringing seed corn preparatory to hanging it up in a dry place for the winter.

they are perfectly dry. When properly dried they may be stored in any safe place which is at all times dry.

Testing seed corn. An ear of corn may look all right, but the grains on it may have lost their vitality to such an extent that they will not grow. A few ears of this kind in the seed used give a poor stand in the field the following year and greatly reduce the yield. To avoid this it pays well to test the germination of each ear. This can be done in the late winter, and the cost is almost nothing, but the result may add many bushels to the next corn crop. A very good method is that known as the "rag-doll" method. First arrange forty-eight ears of seed corn in a row on a platform or the barn-loft floor, fixing the end ears in place by driving nails beside them. Number the ear at the left end I and that at the right end $4 S$, being careful that each ear retains its same position till the test is finished. Take a strip of the kind of cloth known as "sheeting," I 2 inches wide and 4 feet long, and mark it as in Figure 153 . Provide 48 squares, and number each of them as shown for the first few squares in the figure. Next take up ear No. I and 
Securing Best Results from Growing Crops 295

remove six grains from it, spacing the six grains generally over the ear. Place these grains on square No. I on the cloth. Do the same for ear No. 2, placing the grains on square No. 2, and so on till samples have been taken from each ear. It is well to have the cloth slightly damp, so that the grains will stick to it. Now lay another piece of cloth of the same size as the first directly over the grains, being careful not to

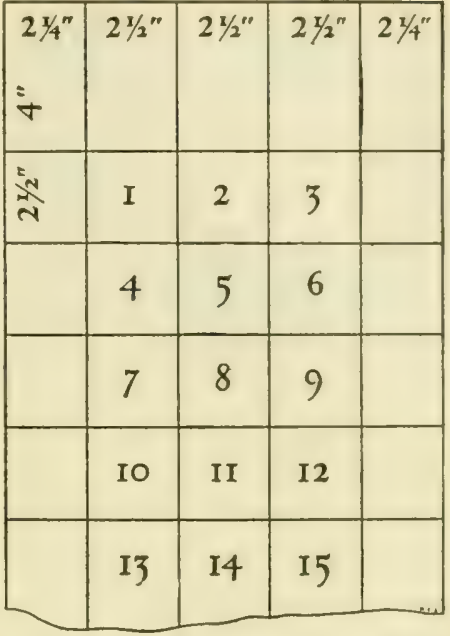

Fig. I53. Cloth $1 \times+$ feet, marked int 1 squares for use in testing seed corn by the "rag-doll" method.

disturb them. Carefully roll up the double layer from the lower end, tie it loosely at each end, and immerse it in lukewarm water till thoroughly wet. Then wrap it in an old newspaper and put it aside in a moderately warm. place. Ordinary living-room temperature is about right. In six days unroll the bundle, being careful not to let any of the grains get off their proper squares. By this time every grain that is sound and fit for seed should be well sprouted. First go through and note every ear the six grains from which have all made good strong sprouts. These ears are the kind to plant. If there are only a few of them, and if the amount of seed saved was not large for the area to be planted, it may be necessary to piece out with some of the ears that gave only five good 


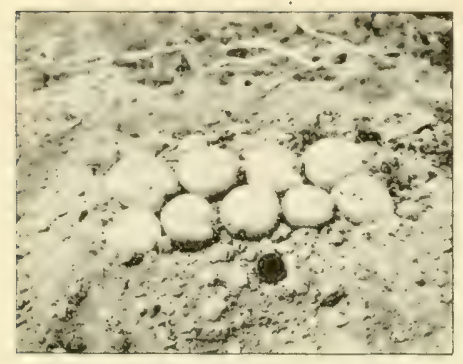

Fig. 154. 1 goued hill of potatoes to save for secul; grown on the farm of L. D. and Frank Sweet, in Culorado.

sprouts; but this ought not to be necessary if a sufficient quantity of seed ears were saved the fall previous. It is a good plan to pick about forty ears of seed for each acre to be planted the next year. This is three times as many as will be needed, and it will give a chance to reject ears that do not show good germination.

Several other methods of conducting this test are given in various bulletins issued by the state experiment stations and the United States Department of Agriculture. Every farmer who grows a considerable acreage of corn should have these bulletins, which may be had for the asking. Progressive corn growers quite generally test their seed corn nowadays, and they make money by so doing.

Selecting seed potatoes. It should be remembered that potatoes (Irish, or white) are propagated from tubers, not from seed, so that every potato in a hill has exactly the same heredity. A small potato from a good hill is better for seed than a good potato from a poor hill. Where the farmer grows his own seed potatoes, which is usually the case in the North, a good way to begin is to dig by hand enough hills to give the necessary seed for next year's planting, saving for seed only those hills that come up to the standard thought to be satisfactory under the conditions (Fig. I 54). Avoid hills 
with too many tubers in them, especially if most of them are small. Avoid also hills that have large, coarse tubers. Save a few of the choicest hills separately, keeping each hill to itself. Next year plant each of these choicest hills in a row to itself and observe closely what each does. The best one or two of these rows should be sared separately again, though there is no use in keeping the different hills in the same row separate, as they all have just the same heredity. In this way it is possible to get a start of good seed.

Planting potatoes for seed. There is some advantage in planting potatoes uncut. But this is very expensive unless the potatoes are quite small. After a good strain of seed has been obtained by the methods outlined above, especially on farms where the potato is an important

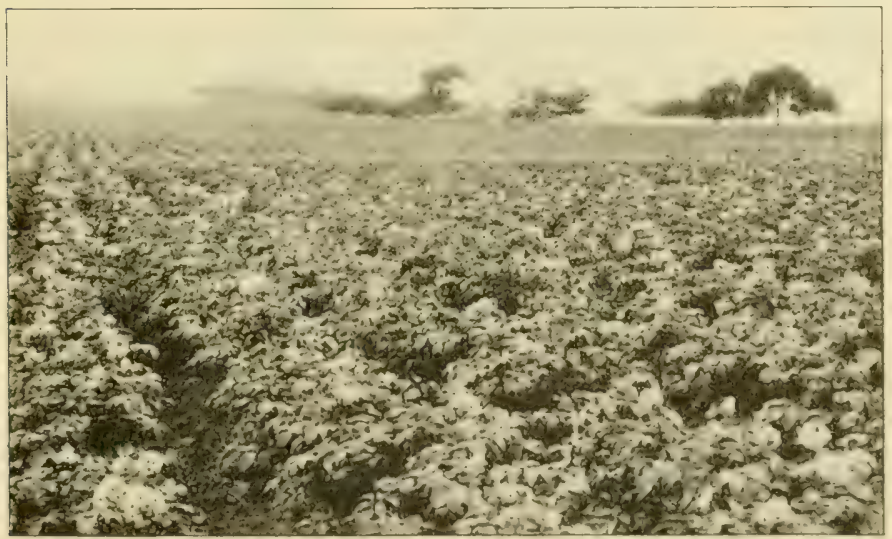

Horliculural Imacstigalions, U.S. D.A.

FiG. 155. A field of potatoes planted thick, for seed, and planted very late (about July I). When potatoes are planted in this way, a large quantity of small ones results. These are planted whole the next year. 
crop, it is a good plan to plant a seed patch late (about July I), and so thick that all the potatoes in the patch
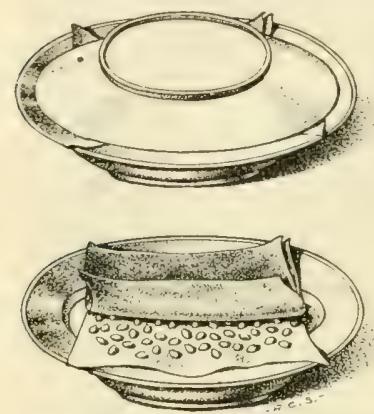

Seed Laboratory, U. S. D. A. will be small enough to justify their use as seed without cutting them. Some of the best potato growers in the country follow this plan. (See Figure I 55.)

Grass and clover seeds. Most farmers buy their grass and clover seed. The principal things to guard against Fig. 156. Testing small seeds, in buying is weed seeds and such as those of grass and clover. seeds of low germinating power. Figure $5^{6} 6$ shows a very good method of testing the germinating power of small seeds of these kinds. Count out one hundred seeds, just as you come to them; that is, do not pick out good seed for the test. Place them on the lower cloth on the plate, put the other cloth over them, seeing that the seeds are well distributed over the lower cloth, moisten the cloths well, put the other plate on top, and leave in a moderately warm place for several days. In four or five days examine the test and take out all seeds that are well sprouted. Moisten the cloths again and repeat the examination every day or two for about ten or twelve days. Then count the seeds that have not germinated. If they are very numerous, either reject the lot from which they were taken or increase the rate of seeding to make up for the poor germination.

In counting out the seeds for this test, look carefully 


\section{Securing Best Results from Growing Crops 299}

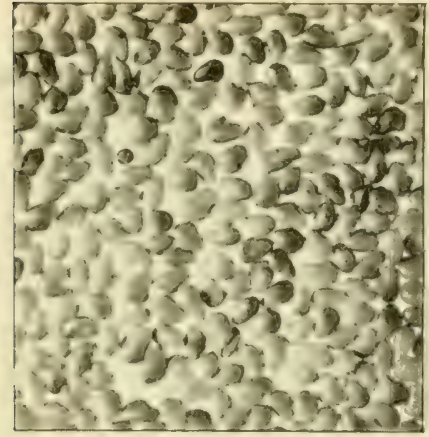

FIG. I57. Good clover seed. A single weed seed present.

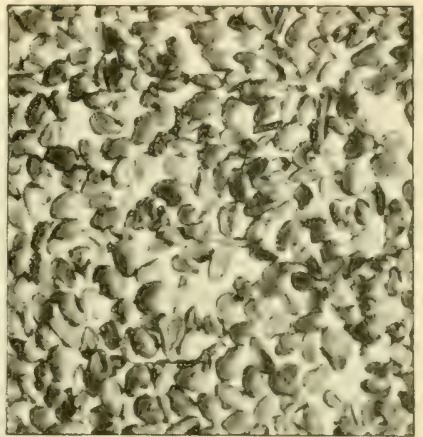

FiG. I58. Clover seed mixed with much trash and with many shriveled seeds.

for weed seeds amongst them. Send to your state experiment station and the United States Department of Agriculture for bulletins on seed testing, which give pictures of the weed seeds commonly found in grass and clover seed. If seeds of bad weeds are present, do not sow the lot from which the sample was taken. These precautions will save a great deal of money and trouble on farms that grow much grass or clorer. Alfalfa is here included with the clovers.

Figure i 57 shows a sample of recleaned clover seed that contains very few weed seeds and relatively few poor seeds. Figure I 58 shows a sample of rery inferior clover seed, containing much trash and a large proportion of shriveled seeds which will not grow.

Seed production as a business. Because of the time and trouble it takes to secure good seed by the methods just outlined, many farmers will not undertake it. Tet many of those who do not care to go to all this trouble 


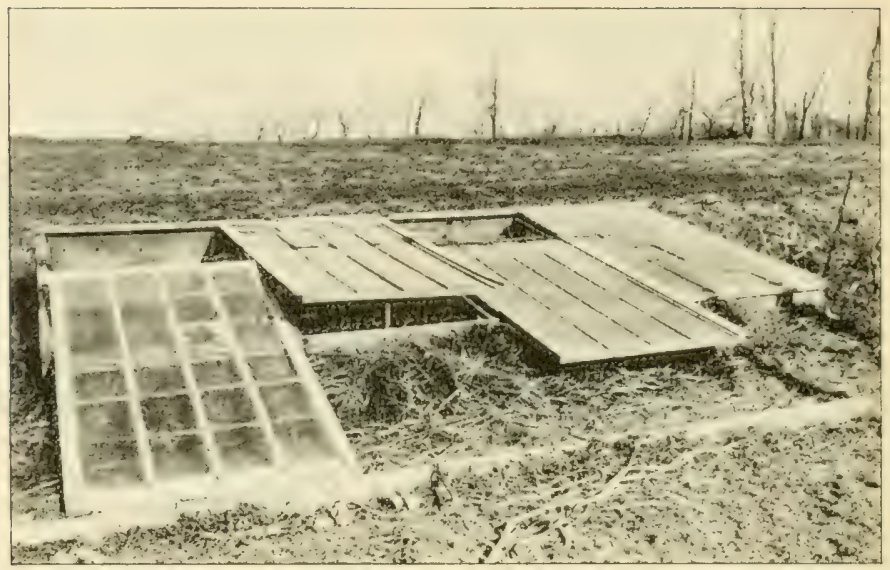

Horticultural Investigations, $U$.S. D.A.

Fif. I59. Cold frames, used by vegetable growers in order to get tender plants started early. The plants are transplanted to the open when warm weather comes.

will readily buy good seed. For this reason the farmer who likes to do work of this kind can usually build up a profitable business by producing good seed to sell to his neighbors.

Cold frames and hotbeds. About the only use the ordinary farmer has for a hotbed is for sprouting sweet potatoes, if he grows them. Such a bed is usually made by burying a thick layer of fresh horse manure under 6 inches of good, soft earth. The heat generated in the fermenting manure warms the soil above, and thus induces rapid growth of the potato sprouts.

Cold frames (Fig. I59) differ from hotbeds in that no measures are taken to warm them. They are covered, usually with sash containing ordinary window glass, to 


\section{Securing Best Results from Growing Crops 30I}

prevent cooling off at night. This keeps frost out unless the weather is too severe.

Those who grow vegetables for early spring markets make much use of cold frames and hotbeds. This permits them to get tender vegetables started before it would be possible to do so in the open, and thus enables the grower to get the benefit of the high prices that prevail early in the season before the markets are flooded with regetables. When the weather has become mild enough, the young regetables started in the cold frames or hotbeds may be transplanted to the open air.

\section{Class Exercises}

If corn is grown in the vicinity of the school, as soon as the corn is ripe enough to save for seed arrange with some farmer to let the class select his seed corn for him for the next year. If the farmer is one who regularly selects seed corn in the field, ask him to show you how he does this work. When the ears have been husked, fasten them together with binder twine or other strong cord, as shown in Figure i52, and hang them up where they will dry properly before cold weather.

Sometime during the winter, make tests for germination of seed corn, as shown in Figure 153. If practicalble, test seed corn for all the neighboring farmers who desire it. Include in the test some ears that have had no special care, and some that have been properly cared for, and see if there is any difference in the vitality of the seed on the two types of ears.

Test several kinds of grass seed of the kinds commonly sown in the community, as shown in Figure 156.

Get several of the best local farmers to tell you how to prepare land for the leading crop of the locality so as to get largest yields, and compare the methods recommended by 
the different farmers. Compare these methods with those of farmers who do not get good yields.

Ascertain the rate of seeding (amount of seed used per acre), or the thickness of planting, of all the principal crops of the locality on several farms. Do you find much variation in this respect? Can you account for this variation?

Ascertain how many ears of seed corn are required to plant an acre. How many acres will a bushel of good seed corn plant? 


\section{CHAPTER TWENTY}

\section{LIVESTOCK ENTERPRISES}

A FARM enterprise is any one of the departments of the farm business - one of the sources from which income is derived. Most farms have one or more livestock enterprises as well as one or more crop enterprises.

\section{BEEF CATTLE ENTERPRISES}

There are three branches of the beef cattle business. These are the raising of calves for beef purposes, the production of "baby beef" (see below), and the fattening of steers. None of these enterprises requires much labor, for which reason they are found on many farms where labor is scarce.

Raising beef calves. While this is a type of farming that requires relatively little capital and labor, it also brings in a small income. Except when the calves are to be finished as baby beef, it is a business which is and should be largely confined to two conditions. In the first place it is an excellent business for the range country, especially where the grass is good. It is hardly practicable on a range that will not support one full-grown animal on fifty acres during the grazing season, and is highly satisfactory on a range where a thousand-pound animal can get enough feed on ten acres. The poorer ranges are fit only for sheep or goats.

In recent years dry-land farmers have driven the cattle off the best ranges and cut down very greatly the number of range steers shipped to the feed lots of the corn-belt states. This reduction in the number of feeders has caused a marked increase in the price of young 
beef animals, a fact which has made the raising of beef calves much more remunerative to farmers.

In the second place, the keeping of a few cows of the beef breeds to graze untillable land and to consume cornstalks, straw, cheap or spoiled hay, etc., enables the ordinary farmer who does not want to engage in other forms of stock farming to convert a good deal of waste material into a salable product. If every farm that now allows things of this kind to go to waste were to keep enough cows to consume them, the supply of beef in this country would be greatly increased and at the same time the farmers would make more money. These same cows might easily produce enough dairy products for home use and even a small amount to sell.

Under present conditions it would hardly be profitable for the farmer to keep more beef cows to raise calves than can find their living largely as scavengers, unless the cows are registered stock and produce calves that can be sold at good prices as breeders.

Baby beef production. The term "baby beef production " is applied to the business of feeding calves liberally from the first till they are nearly or quite two years old, having them in prime condition for slaughter at this age (Fig. I60). To succeed in this business it is necessary to have a good quality of calves, and to get these it is usually necessary to raise them. With the proper kind of cattle, especially when the cows are fed largely on waste materials, a farmer who has plenty of good feed and knows how to use it can make money out of baby beef.

Fattening steers. When young cattle raised on the range were available to corn-belt feeders at low prices, 


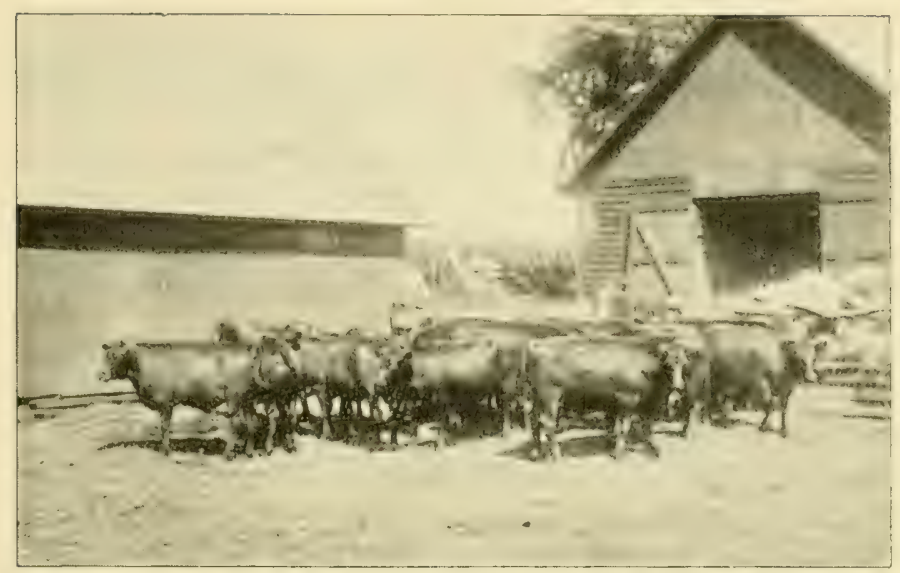

Office of Farm Management (J.S. Cotlon)

Fig. I60. Iowa baby beeves.

as was the case a few years ago, the feeding of steers on corn-belt farms was a very good business. Now that the price of feeder stock has become very high, the steer-feecling business has become uncertain. The margin of profit in it is small at best, and the price of fat cattle varies greatly from month to month. When the farmer goes to the big market centers to buy feeders he may have to pay a high price, and when he goes to sell prices may have dropped, and then he loses money. By far the most important factor in successful steer feeding is to buy wisely. This means either that the cattle bought for feeding must be exceptionally good or the price must be low. The greatest dificulty with this business is the fact that when the farmer buys his steers he has no means of knowing what the price of fat cattle may be several months later when he is ready to sell. 
Some farmers buy their steers in the fall and fatten them during the winter. Others carry them through the winter on cheap rough feeds and then fatten them on grass the next summer, either feeding grain on grass or depending entirely on pasture. Still others buy in the spring and fatten on pasture, usually without grain. Some farms devoted to this last type of steer fattening have all the land in grass. It takes very little labor to run a big farm in this way. Although the profits are small, expenses also are small, and the profits are fairly certain.

Most farmers who make a business of steer feeding do so either as a means of keeping up the fertility of their land or because they are short of labor. What is said here about steer feeding applies mainly to corn-belt conditions. There are localities here and there in the West and South where, because of abundance of pasture or of cheap hay of good quality, the fattening of steers may be quite profitable, especially when the value of the resulting manure is taken into consideration.

\section{DAIRYING}

Importance and distribution. Dairying is by far the most important livestock enterprise in this country. At the last census there were twenty million dairy cows as against thirteen million steers and bulls. The magnitude of dairying as a farm enterprise increases markedly as we go north and decreases southward. The principal reason for this, as previously stated, is the increasing importance of the dairy cow as a means of furnishing winter employment to the farmer. Another reason why dairy- 
ing is not more prominent in the South is the difficulty of handling milk and cream in the hot summers of that section.

Phases of dairy farming. There are three more or less distinct phases of dairy farming in this country; namely; the production of butter, the production of milk or cream for creameries, cheese factories, or condensarics. and the production of market milk - that is, of milk for consumption as milk in the cities.

Butter production on the farm. While dairy farmers formerly produced great quantities of butter, it is rare now to find a farm engaged in this business. Creamery butter sells at so much better prices than the ordinary run of farm-made butter that it is usually more profitable to sell cream to creameries than to make butter on the farm. Here and there a farmer who can make a very high grade of butter, and who is in position to sell his butter to special customers at good prices, still continues in the business. Generally speaking, butter making on the farm is confined to home needs or to localities where the cost of delivering milk to a factory or shipping station would be prohibitive.

Production of milk or cream for factories. City milk dealers usually pay more for milk or cream than factories can afford to pay. For this reason the factories. especially creameries and cheese factories (Fig. I6I), have to a great extent been driven out of the regions near the large cities. Condensaries can pay more than creameries and cheese factories, hence a good many condensaries are still found in regions that could ship milk to the cities. 


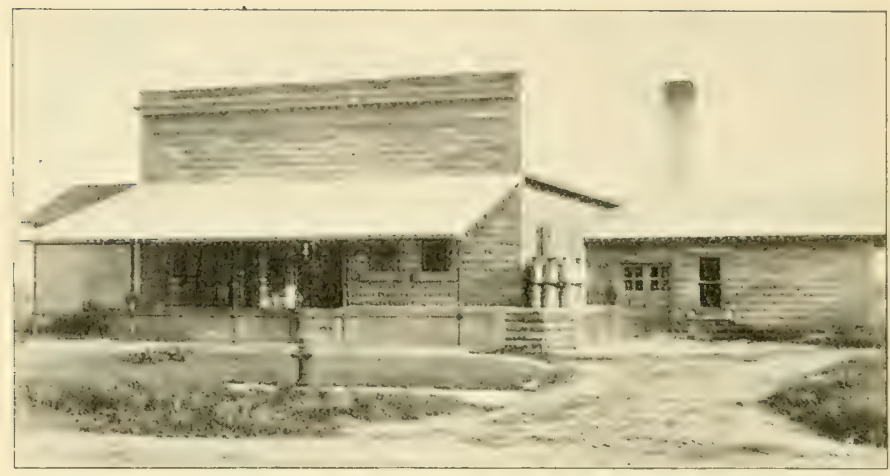

Dairy Division, U.S. D. A.

Fig. I6I. A combined creamery and cheese factory in Wisconsin.

Cheese production in this country has become largely centered in Wisconsin and in those parts of New York not well situated for shipping milk. Cheese production is decreasing in New Iork as the demand for market milk increases.

Creamery butter production has for many years been gradually disappearing in the Eastern dairy sections, being driven out by the market milk business, but has increased enormously in the Middle Western and Far Western states. It is the leading phase of dairy farming in the last-named sections. The cheapness of feeding stuffs in the West makes creamery milk production a fairly profitable business if good cows are kept, especially when the value of manure is taken into consideration.

Market milk production. The enormous growth of cities in recent years has created an ever increasing demand for market milk, and the production of this commodity has become the leading feature of farming in the 


\section{Livestock Enterprises}

vicinity of many cities. Figure 162 shows a familiar sight in a New England village just before the milk train arrives. Because of the great number of large cities along the Atlantic seaboard, and the fact that there is no land on one side of these cities, as well as the fact that much of the land on the other side is too rough for ordinary farming, there is now little room in the East for any other type of dairying. Some of these cities are now shipping milk more than 300 miles, and sometimes eren 500 miles. The great abundance of good farming land near the great cities of the Middle West makes the situation there quite different.

There is room for one or more good market milk farms in the vicinity of every town or village. Few families in towns and villages use less than a quart of milk a day. A good dairy cow should give at least 2300 quarts a

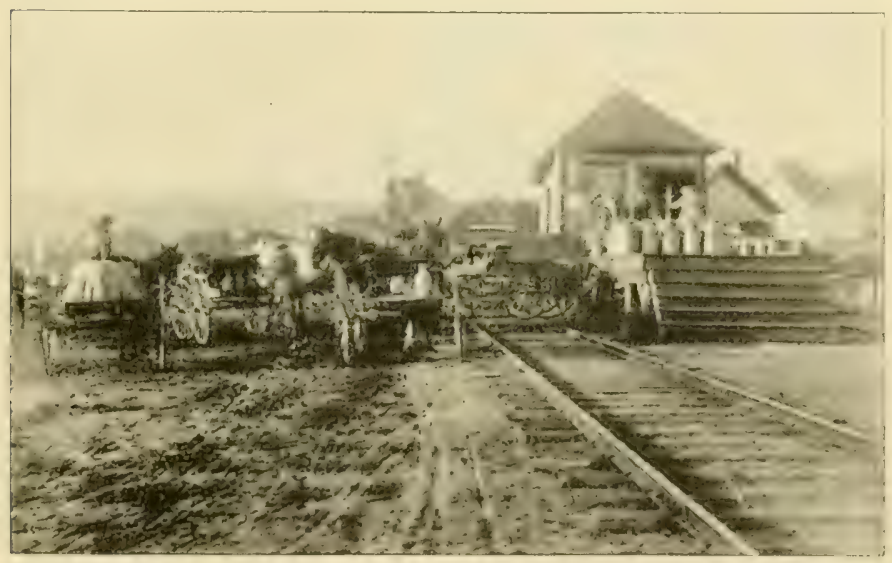

Fic. Iu2. Farmers delivering milk at a railroal station in New Hampshire, for shipment to Boston. 


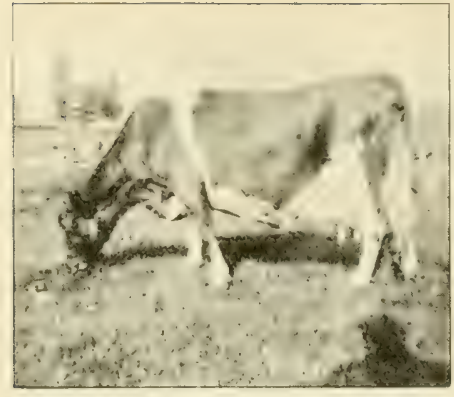

Fig. I63. This New Jersey Guernsey gave over 600 pounds of butter in a year. Such cows are profitable. year, - enough to supply about $6 \frac{1}{3}$ families I quart a day each. This is at the rate of I cow to each 32 inhabitants, counting 5 persons to the family. It would thus take about I 56 cows to supply a town of 5000 people, or, say, a herd of 15 cows for each 500 people. This takes no account of cows kept in town. With good cows, and a system of selling that does not result in a lot of losses from unpaid bills, the market milk business may be made profitable. One good way of preventing losses from unpaid bills is to sell in advance to each customer milk tickets, each of which is good for a quart of milk.

Importance of good cows. It is estimated that the average cow kept for milk on American farms produces about 3500 pounds, or 407 gallons, of milk a year. This is slightly more than a gallon a day for the year. Such cows are not profitable. The effect that quality of cows has on farm profits is well shown in the accompanying table, in the case of $2 S_{9}$ dairy farms in Pennsylvania. These farms are situated near a great city and sell their milk to city dealers at good prices; hence the business is somewhat more profitable than the average. By labor income is meant the amount that is left of the net farm income after deducting interest on the farmer's investment. It is what he gets for his labor and managerial 
ability. These farmers all got about the same price for their milk, so that the difference in receipts per cow

\begin{tabular}{|c|c|c|}
\hline \multicolumn{2}{|c|}{ INCOME PER COW } & \multirow{2}{*}{$\frac{\text { LABOR INCOME }}{\text { Average }}$} \\
\hline Limits & Average & \\
\hline$\$_{50}$ or less & $S_{42}$ & $S_{418}$ \\
\hline 51 to 60 & 57 & 592 \\
\hline 61 to 70 & 68 & 783 \\
\hline 71 to 80 & 75 & 782 \\
\hline 8 I to 90 & 86 & $83 I$ \\
\hline 91 to 100 & 96 & I 185 \\
\hline IOI to I 20 & I IO & 1422 \\
\hline I $2 I$ and over & I3 8 & 1602 \\
\hline
\end{tabular}

on the different farms is in the main due to difference in the amount of milk the cows gave. It is seen that those that had the best cows got about four times as much for their labor as did those whose cows were the poorest. Figure ${ }^{6} 6_{3}$ shows a cow with good dairy form. Such

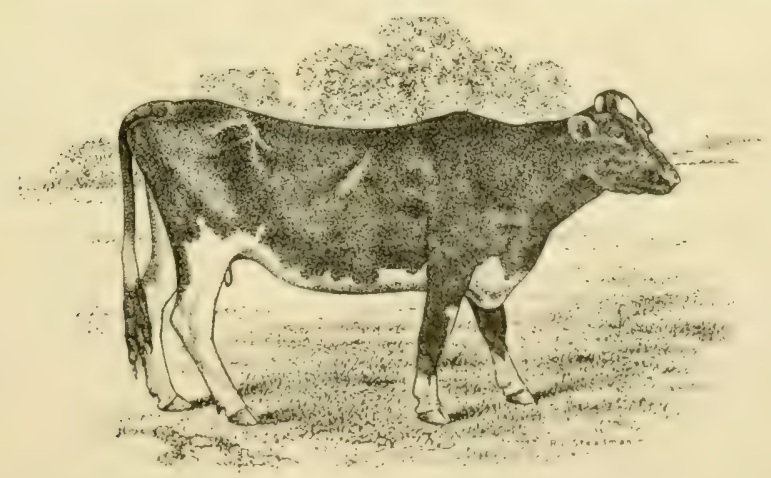

Fig. 164. This cow gave only about 200 pounds of butter in a year. Note the difference in form of body between this cow and the one shown in Figure 10 s. 
cows are profitable, while those like the one in Figure I64 hardly pay for their keep.

Unless it is possible to buy good cows at reasonable prices, which is not often the case, it is absolutely essential that the dairy farmer use good bulls as a means of building up his herd. These bulls should not only be of a dairy breed, but they should be from stock known to be good producers. The best way for the small farmer to accomplish this is to join an association whose object is to keep good bulls for its members. When a bull has been on one farm a few years he can then be moved to another, if he has proved to be satisfactory, instead of being sent to the slaughterhouse. In this way a few good bulls will suffice for quite a number of farms.

Price of butter fat as compared with that of butter. When milk is examined under the microscope, it is seen to contain many small drops of oil. This oil is called bulter fat, for it is the principal constituent of butter. But butter also contains about i6 per cent of other things, such as water, curd, milk sugar, salt, etc. Hence a pound of butter fat will make more than a pound of butter; roo pounds of butter fat in milk will make from roS to I 6 pounds of butter, according to the skill of the butter maker; Ioo pounds of butter fat in good rich cream will make from iI 5 to 25 pounds of butter. This additional amount of butter made from a given amount of butter fat is called the "over-run." With good management the value of the over-run will more than pay the expense of operating a creamery. Hence, when butter is selling at 25 cents a pound, the creamery 
can afford to pay a little more than 25 cents a pound for butter fat. Where it pays less, there is either incompetence in the management or the farmer is not getting his share of the proceeds. A creamery doing a large business can afford to pay 2 or 3 cents more per pound for butter fat in cream, and from half a cent to a cent more for butter fat in milk, than it gets for butter.

Relation of dairying to labor. Dairy farming requires more labor than any other kind of stock farming, unless it is poultry raising. For this reason we say it is an intensive type of stock farming. Beef-cattle farming, requiring little labor, is said to be cxtcnsice. Because of the amount of labor on dairy farms it is a business especially adapted to farms having an abundance of labor, especially where the laborers are members of the family. Hired labor is frequently hard to get on dairy farms, for many men do not like the work.

It takes about I 50 hours of work per year to care for a dairy cow and her milk. Twenty cows would require 3000 hours, or 300 ten-hour days, which is pretty full work for an ordinary man. The unfortunate part of it is that some kinds of this labor must be done on Sundays the same as on other days. Taking the year through, 20 cows would require 4 hours' work each Sunday and a little less than o hours a day on week days.

On farms devoted chiefly to dairy cows and the raising of feed for them, it is estimated that to care for the cows and do the necessary field work requires about one man to each I 2 or 15 cows. On one very large dairy farm in New Jersey the men who milk the cows do no other work, not eren feeding. These men milk from 30 to 35 


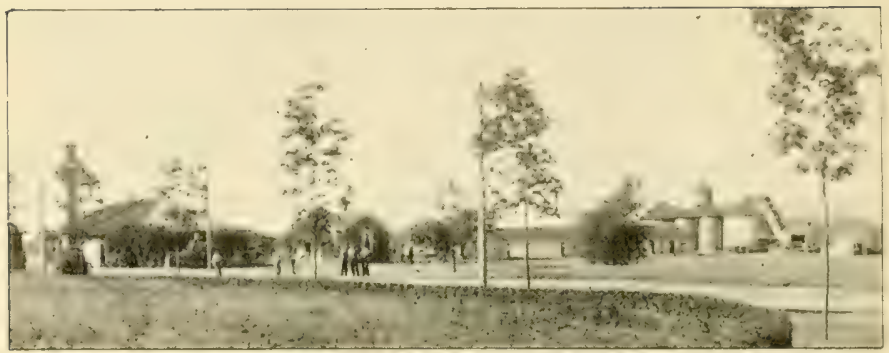

G. A. Billings

FIG. 165. These croquet players milk 30 to 35 cows each, twice daily, and like their work. They are employed on a large dairy farm in New Jersey.

cows each twice a day, putting in about 5 hours twice daily at the task. To milk 35 cows in 5 hours takes 8.57 minutes per cow, which is not rapid work. A speedy milker can easily average a cow to 7 or 8 minutes. The milking on this farm is done from 2 to $7 \mathrm{~A}$.Mr. and 2 to 7 P.Mr. The men sleep from about 7.30 P.M. to nearly 2 A.M., and rest, read, sleep, or play games from breakfast time till milking time in the afternoon. Figure $6_{5}$ shows these men playing croquet. They get good wages and like the work. Such a system is suited to any farm that has enough cows to keep the milkers busy for 9 or ro hours a day.

The very fact that dairying furnishes so much labor makes it a desirable enterprise for farms that are too small to give the farm labor full employment in the fields. It gives the small farmer a chance to earn more wages.

The dairy herd as a market for crops. In many localities the farmer can get more for his crops by feeding them to a good quality of dairy cows than by selling. 


\section{Livestock Enterprises}

Even when the cows do not return the full market price for the crops. it may still be more profitable to feed them to dairy cows. Thus, in a survey in Chester County, Pennsylyania, in 1912, it was found that on the average the income per cow from the sale of milk was $\$ 80$ a year. The total cost of keeping each cow per year was about S95. Tet, even under these conditions, those farmers who fed their hay and corn made more profit than those who sold them. In the first place, the cows returned nearly as much for the crops as could have been obtained on the market. In the second place, the manure of each cow was worth $S_{15}$. Finally, the cows not only gave fairly remunerative employment all winter long, but converted waste land pasture, cornstalks, straw, and damaged hay into a salable product.

\section{HOG RAISING}

Hogs make more growth on a given amount of feed than any of the larger farm animals. At least half of their feed, when hogs are kept in small numbers, may consist of pasture, skim milk, refuse apples, unmarketable potatoes, undigested grain in cattle manure, and other waste materials about the farm, including refuse from the kitchen and garden. With good management hogs may be used to harvest a part of the corn crop, and eren the small grains, such as wheat and rye. This process, known as "hogging down" crops, saves labor. and at the same time leaves valuable humus-making material to turn under. (See Figure I66.)

A bushel of corn, if properly fed, will make ro pounds of increase in live weight in hogs. Hence, when the 


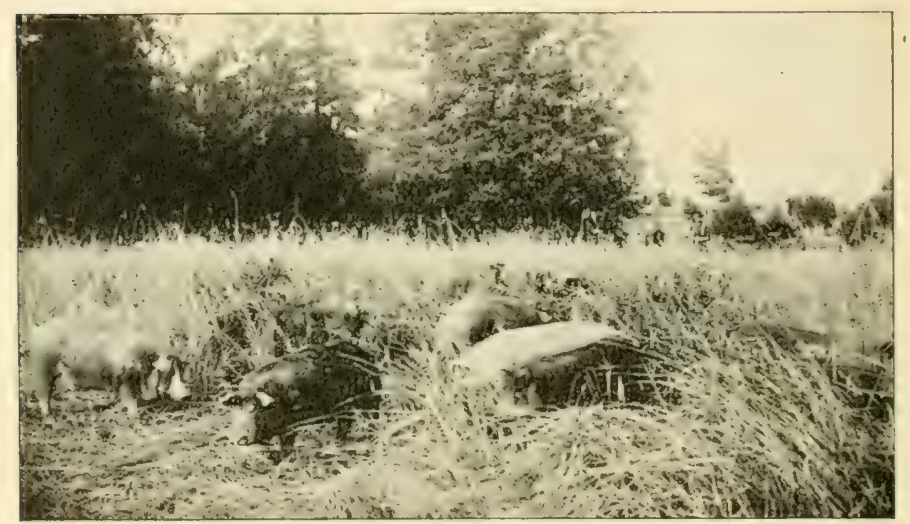

Office of Farm MInusement (J.A. Drake)

Fig. 166. Hogging down rye on a successful Ohio farm.

price of a bushel of corn is less than that of ro pounds of live hog, a better price can be obtained for the corn by feeding it to hogs than by selling it. Every farmer should keep at least as many hogs as can be fed largely on waste materials, supplemented by enough grain to put the hogs in marketable condition.

Hogs are subject to one very fatal malady-cholera. This disease causes farmers every year the loss of sereral million dollars. Because of this danger it is seldom wise for the farmer to depend too largely on hogs as a source of income. There is now a means of inoculating hogs to prevent the disease, but it is not always easy to apply this preventive.

\section{SHEEP ON THE FARM}

When farmers' wives wove the cloth from which the clothing of the farm family was made, which they did 


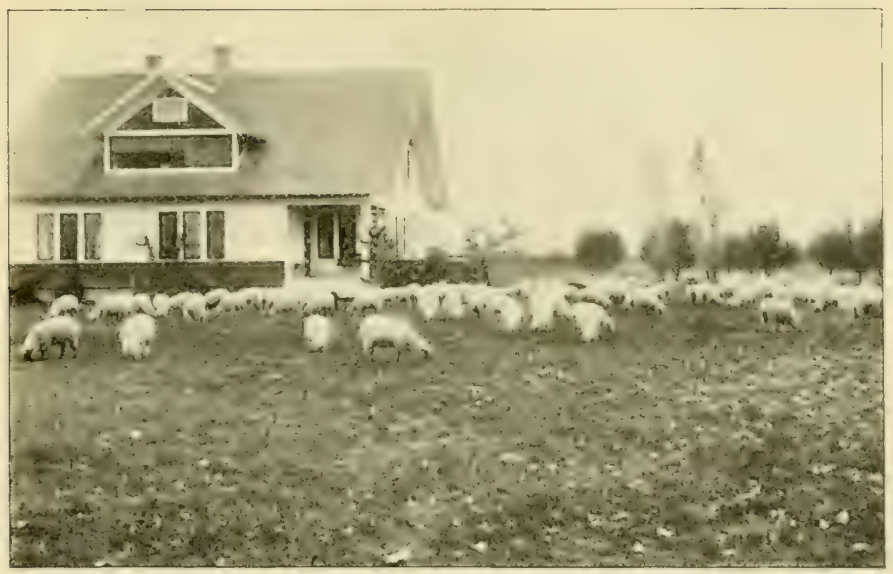

Offec of Farm Management (S: .1T. Thomson)

FIG. I67. A farm flock of sheep. They make good lawn mowers.

fifty or more years ago, sheep were found on nearly every farm. But with the development of woolen mills, and especially with the development of the range business in the West, sheep largely disappeared from farms but became numerous on Western ranges. Now that the ranges can no longer furnish the wool and mutton required in this country, the price of sheep has risen until it is beginning to be profitable to keep them on farms again. A small flock of sheep can live almost entirely as scavengers on an ordinary farm, unless there is a great deal of other livestock to consume waste materials. The income from such a flock is nearly all profit. Figure ${ }_{167}$ shows a flock of this kind, eating grass in a dooryard.

When sheep are kept in considerable numbers on the farm, trouble arises from the fact that these animals 
are subject to certain internal parasites (stomach worms, liver fluke, etc.) that become very bad when the sheep run over the same land many times during the season. The sheep scatter the eggs of these parasites in their manure. When the eggs hatch, the young worms crawl out on the grass, where the sheep eat them again. The difficulty is not so bad if the sheep can be frequently moved about from field to field or from one pasture to another.

Dogs also are a serious drawback to the sheepman. Many farmers who now keep no sheep would do so if it were not for sheep-killing dogs. Good dog laws, strictly enforced, would do much to put sheep farming on its feet again.

Many farmers in the Middle West buy Western range lambs to fatten during the winter. This is a very different business from the keeping of a flock of breeding ewes. Where hay and corn are plentiful and cheap, it is a good business.

\section{PLACE OF GOATS IN AMERICAN FARMING}

In parts of the South a few ordinary goats are kept as pets or as scavengers on the farm. They are quite prolific, and if only such numbers are kept as can be fed largely on waste materials they may add a good many dollars to the farm income. Large herds of Angora goats are found on certain of the ranges of the Southwest, especially where most of the feed is too coarse for sheep (Fig. I68). Aside from this, about the only place for goats on American farms is to help in clearing land. They are very fond of the young sprouts that come up 


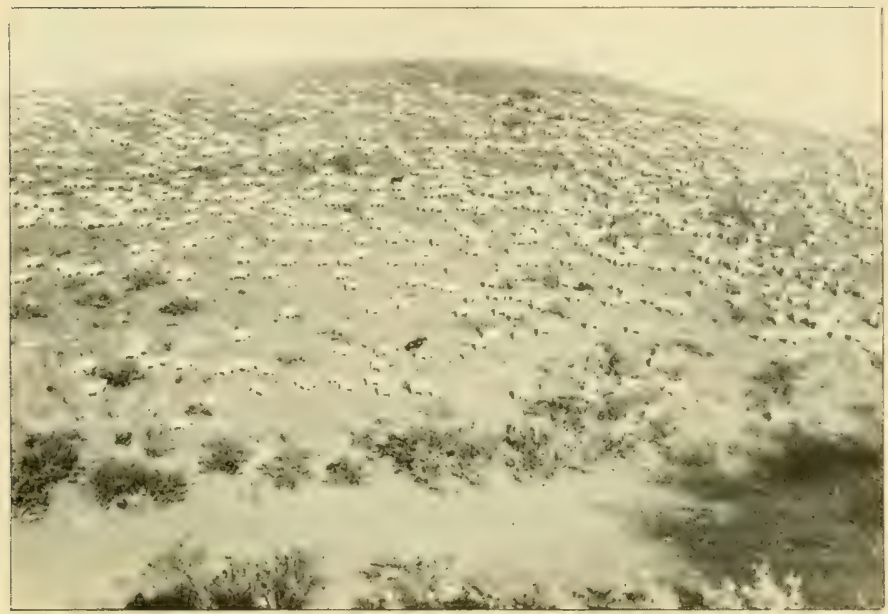

Uflice of Farm Management (David Griffilhs)

Fig. I6S. Angora goats on a New Mexico range.

from stumps, and will keep the sprouts eaten down in a clearing if enough goats are used. This causes the stumps to decay more promptly.

\section{THE POULTRY BUSINESS}

There is room for a flock of poultry on every farm, the number depending partly on the size of the farm, but more on the crops grown and the other livestock kept. Within certain limits a flock like that shown in Figure i69, or even a larger flock, can find most of its feed in waste grain, weed seeds, insects, etc.; their shelter may be constructed mainly from waste lumber: and the women and children may do most of the work connected with their management. Under such conditions the actual cost of a flock of hens is almost nothing, 


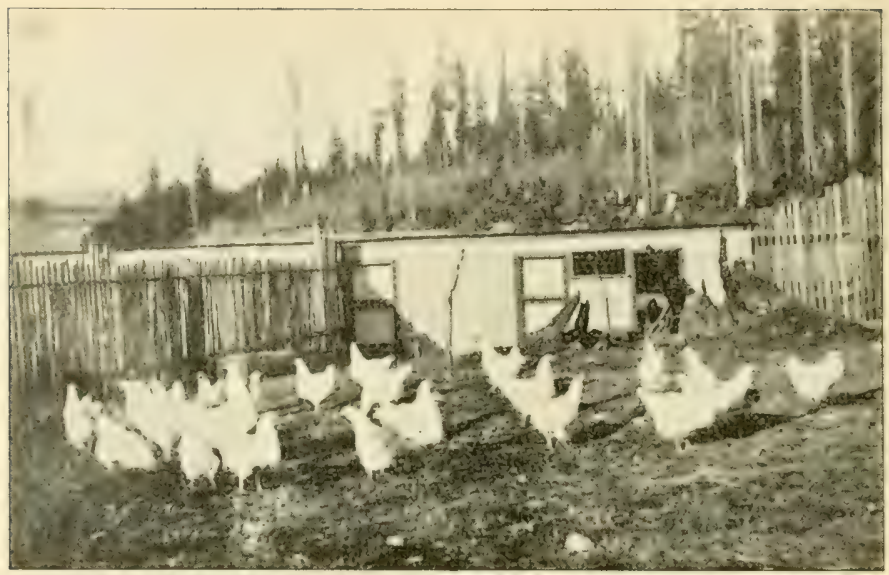

FIG. I69. Flock of farm poultry in the Puget Sound region.

and the income from them is nearly all profit, to say nothing of the meat and eggs they furnish toward the family living. If the hens are of a good strain of a general-purpose breed they should, with ordinary farm care, lay at least five dozen eggs per head per year. With a little more attention to their feeding and care this can easily be increased to six or seven dozen.

The problem is quite a different one when the number of hens becomes so large that they must receive special attention, for then they must be fed valuable crop products, materials must be bought for constructing shelters, and some time must be given them from other farm work. Until recently the amount of poultry products obtained from ordinary farm flocks was sufficient to supply the demand for products of this kind. Because of the small cost of such flocks the poultryman found it difficult to compete with the general farmer. 
To do so it was necessary for him to use some skill in breeding goorl egg-laying strains of birds. It is fairly easy with a little intelligent study to get an average of ten dozen eggs per hen, and some poultrymen get as high as twelve dozen or more. With such yields the poultryman could compete with the farmer. But in recent years the farm supply of eggs and poultry no longer meets the demand, and prices have risen till poultry raising has become a rery good business, especially in the'hands of a good manager who is a real student of the subject. However, the sudden marked increase in the price of feed when the great European war began to affect this country was very disastrous to poultrymen, and many of them went out of business.

Usuaily the farmer who keeps more hens than can live largely on waste materials loses money on them unless he gives some attention to increasing egg production by breeding up his flock. But if he gives the matter sufficient study, the poultry business may well be marle one of the principal enterprises of the farm. Especially in regions near the great cities, and more especially. where the farms are too small to give full employment on crops, the poultry business has grown to considerable proportions in recent years, and bids fair to increase in magnitude.

\section{Class Exercises}

List the sources of income and the amount of income from each source on a considerable number of near-by farms. Find the percentage of income from each source on each farm. What is the total percentage of income from crops? from livestock? 
Find the corresponding percentages for all the farms taken together as one farm.

The "type" of a farm is determined by its principal source or sources of income. If an enterprise furnishes half or more of the income, that enterprise is usually given as the type. In some cases several enterprises must be included in the type name, because no one enterprise predominates. Determine the type of each farm studied. 


\section{CHAPTER TWENTY-ONE}

\section{THE FARM INVESTMENT AND INCOME}

Farm property. For purposes of taxation, and other legal purposes, farm property is divided into real cstate and personal property.

Real estate consists of land and its permanent improvements, such as buildings, fences, drainage system, and water supply. All other property belonging to the farmer is considered personal property.

In studying the business of farming we may divide the property of the farmer into three classes; namely. real estate, working capital, and personal capital. In this classification, the term "real estate" is used in its ordinary legal sense as given above.

Working capital, in farming, consists of work animals, productive livestock, implements and machinery, feed and supplies, and cash for current expenses. When a farmer uses credit instead of cash for current expenses, the amount of credit thus used should be considered a part of his working capital, for the business must earn interest on it.

Personal capital consists of things kept on the farm but not used in the farm business. The farm business is not expected to earn interest on them. The most common forms of personal capital are household effects, farm products held for sale, pleasure vehicles, driving horses, and pet stock. The farmer keeps these things: either as a speculation, or for the pleasure or convenience of himself and family. He must pay taxes on them, but he is supposed to support them out of his profits, and should not make them a charge against the farm business in calculating the net farm income. 


\section{THE FARM INCOME}

The farm income for the year is the difference between the receipts and the expenses.

Receipts consist of

I. Sales of farm products produced during the year.

2. Farm products of this year's production held for sale.

3. Increases (if any) in the value of

a. Permanent improvements.

b. Livestock.

c. Implements and machinery.

d. Feed and supplies.

4. Miscellaneous receipts, such as rent of farm buildings, pay received for work outside the farm, etc.

The total receipts of the farm may be arrived at by taking an inventory at the beginning and at the end of the year, and by keeping a record of the sales of farm products, and of receipts from miscellaneous sources.

Expenses consist of

I. Expenditures for
a. Labor.
b. Feed.
c. Miscellaneous purposes.

2. Purchases of livestock.

3. Decreases (if any) in the value of
a. Permanent improvements.
b. Livestock.
c. Implements and machinery.
d. Feed and supplies. 
Distribution of farm income between labor and capital. The farm income represents interest on the capital invested and wages for the farmer's labor and managerial ability. We may assume that the farmer's work and managerial ability are worth a given sum, deduct this sum from the farm income, and thus find the income on the investment. By dividing this income on investment by the amount invested, we find the per cent income on the investment. Thus, if the net farm income in a given case is Sro0o, the total investment Sro.000, and the value of the farmer's work and managerial ability $\$ 400$, then the income on investment is $\$ 600$, which is 6 per cent on the investment.

On the other hand, we may assume that capital inrested in farming is entitled to, say, 5 per cent interest, and then calculate the farmer's labor income on this basis. In this case the interest on the investment of $\$ 10,000$ is $\$ 500$. Subtracting this from the farm income of $\$ 1000$, we have $\$ 500$ as the labor income of the farmer. This represents what the farmer gets for his labor and managerial ability on the assumption that the capital is entitled to 5 per cent income.

What the farm furnishes toward the family living. In the above calculations, no account was taken of what the farm furnishes directly toward the family living. An investigation of 950 farms in $1+$ states showed that on the average for all these farms the value of foost furnished to the farm family directly from the farm was $\$ 260$. The farm also furnished $\$ 3.3$ worth of fuel; and the rental value of the farm dwelling, which is considered a part of the farm property, amounted to $S_{132}$ 


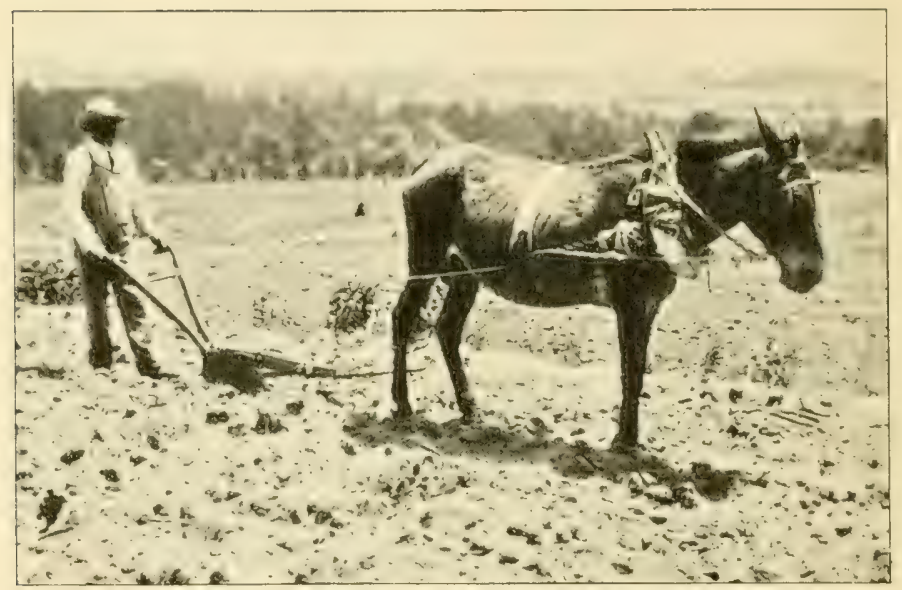

FIG. I70. This man creates little wealth by a day's work, and his income is small.

a year. These three items total $\$ 425$. This of itself is a considerable income, and should be taken into account in comparing the farmer's income with that of the city man whose home is not connected with his business.

\section{INCOME PER MAN VERST'S INCOME PER ACRE}

One man, with nothing else to do, can take care of about 5 acres of strawberries, except at picking time. With a fair yield and fair prices, he should net something like $S_{100}$ per acre, or $\$ 500$ for his season's work. This same man, with a good two-horse team, could grow 40 acres of corn and 60 acres of wheat, with no help except at harvest and corn-husking time. With corn yielding 40 bushels per acre and selling at 60 cents per bushel, and with wheat yielding 16 bushels per acre and selling at \$i per bushel, his gross income would be \$1920 a year. Out of this he would have to feed his team, 
pay for harvest labor, and allow a fair rent for the larger area of land. But with all these expenses taken out he would still have a much larger income than the man growing the strawberries.

Cotton ordinarily brings in much more per acre than corn or wheat, but the necessity of picking cotton by hand limits the amount the average family can manage ts about 7 bales. This may easily be grown on 12 or I 5 acres, or even less. One horse can easily do the horse work required on such an area and cultivate enough more land to produce his own feed. Hence one-horse farming prevails very generally in the cotton-growing country. Figure r 70 shows a typical scene on a onehorse cotton farm. When a man is following one small mule hitched to a plow or cultivator, he is not creating a great deal of wealth in a day, and his pay is accordingly small. How much greater the wealth created per day

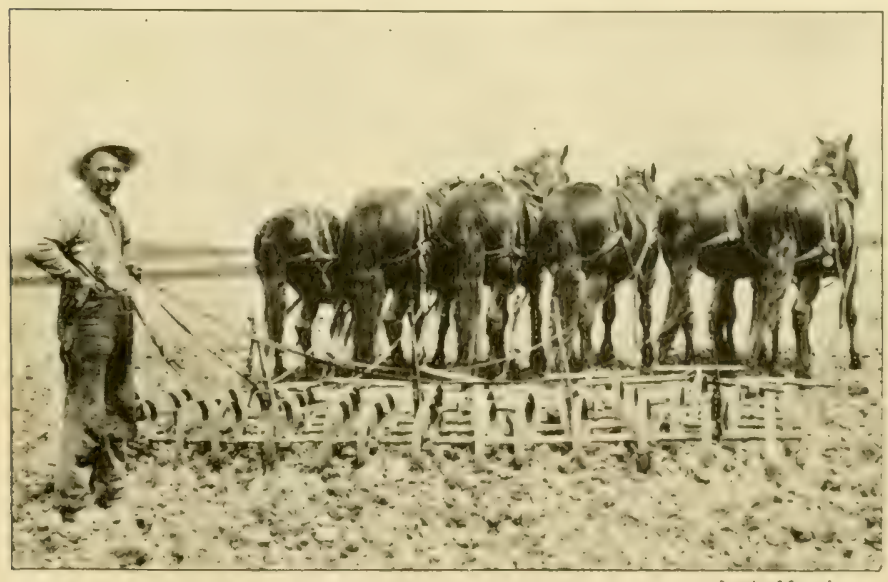

L. A. Monrhouse

FIG. I7I. This man creates much wealth in a day, and his income is high. 


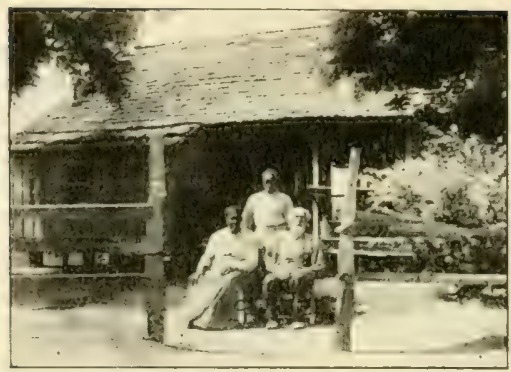

Office of Farm Management (M. A. Crosby)

Fic. 172. This farmer gets an income of over $\$ 200$ an acre from his land, but he farms only two acres.

of labor by the farmer who utilizes the power of a team like that shown in Figure $\mathrm{I} 7 \mathrm{I}$.

The farmer who devotes his time to a very few acres, as is usually necessary if he grows only crops that make a large return per acre, not infrequently has a very small net income, while the farmer who follows a type of farming that enables him to till a large acreage, even if the income per acre is smaller, may have a much better income. Figure 172 shows the home of a cotton farmer who probably gets the largest income per acre of any cotton farmer in America, but he tills only 2 acres. Figure 173 shows the home of another Southern farmer who gets much less per acre, but who farms a much larger acreage. He is much more prosperous than the 2-acre farmer. In this, as in many other matters, the golden mean is often the best for the individual farmer. It is desirable that every acre be made to produce as much as possible, provided enough such acres can be tilled by one man to make him a satisfactory income. 


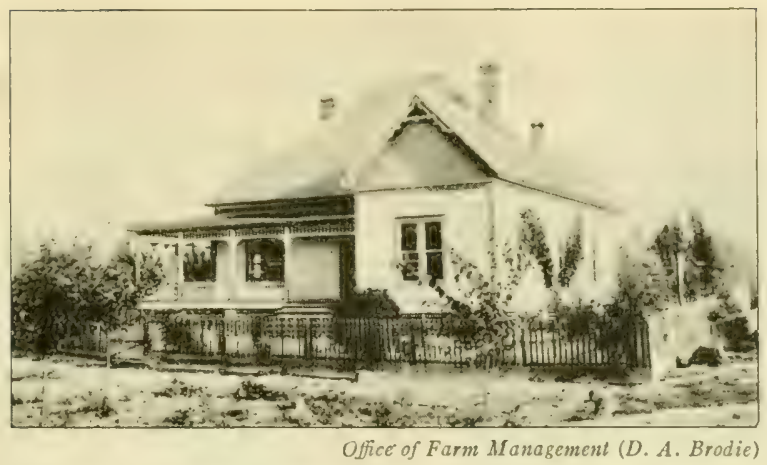

FIG. 173. The owner of this farm home gets only about $\$ 20$ an acre from his land, but he farms one hundred acres.

\section{FACTORS AFFECTING THE FARM INCOME}

Fluctuation in prices. Prices of farm products fluctuate widely from year to year. This, of course, has an effect on the farm income. But as this is a factor over which the farmer has little control, we need not consider it further than to say that by putting on the market superior products he can get a higher price for them.

Method of marketing. In many cases the method of marketing has much to do with the price the farmer receives for his product. Frequently by joining a cooperative association it is possible to get higher prices by eliminating unnecessary middlemen's profits. This is particularly true when the farm is devoted to the production of perishable commodities like fruit or vegetables for shipment to a distant market. The farmers shown in Figure $17+$ are members of such an association. These farmers received an average of 15 cents a bushel more for their potatoes than those of other near-by localities 


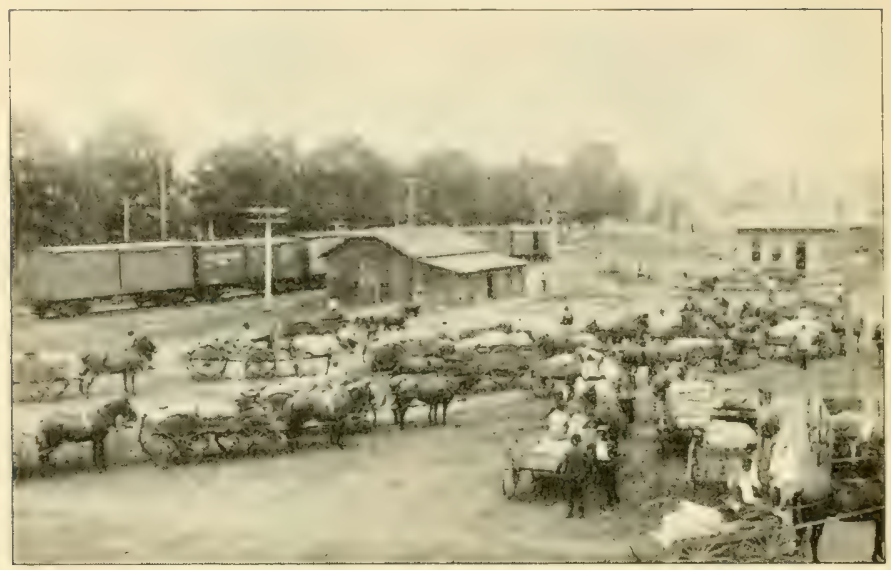

FIG. I74. Members of a Texas farmers' coöperative association waiting to load potatoes on cars. The assuciation gets better prices for its members than they formerly received when selling as individuals.

where there was no coöperative marketing. Sometimes local warehouse men and millers pay much less for the farmer's grain than could be obtained through a farmers' coöperative warehouse association.

Choice of enterprises. In newly settled regions it frequently happens that farmers make serious mistakes in deciding what crops to grow and what livestock to keep. The results of such mistakes are often serious. But in older-settled communities the farmers have usually had time to try out nearly every kind of farming possible in the region, and such mistakes are not so frequently made. The types of farming that do prevail in any well-established agricultural region generally represent the result of much experimenting on the part of the farmer. Those types not adapted to the local 
conditions naturally disappear, because those who follow them fail. This leaves those types that are suited to local conditions. But when local conditions change, corresponding changes must be made in types of farming.

Relative magnitude of enterprises. In a study of a large number of farms in Pennsylvania, the percentage of the farm acreage devoted to hay varied widely. Some men had less than 20 per cent of their land in hay, while others had over 60 per cent. It was found that on the average those who had about 45 per cent of their land in this crop made more money than those having more or less. This shows that the farmer must use judgment in deciding what acreage each crop he grows should occupy.

In a similar study in South Carolina it was found that those farmers made most money who had about 60 per cent of their land in cotton and the remaining 40 per cent in feed and food crops. In the "Blackwaxy" region of Texas the corresponding percentages were $S_{5}$ and $\mathrm{I}_{5}$. The South Carolina farmers used one-horse implements, and hence had to use more laborers. These required more bread, meat, etc. The Texas farmers used two- and four-horse implements. This required fewer laborers, so that more of the land could be devoted to cotton. In both these cases it was found that the prevailing system of farming is gradually wearing out the land, and hence will have to be changed in the not distant future unless some means can be found for building up the land.

Unless some one crop or kind of livestock is very 
much more profitable than anything else, it usually pays to choose the farm enterprises so that the labor available on the farm will be kept comfortably busy the greater part of the year. To do this adds greatly to the farm income.

Size of farm. Many farmers make the mistake of working a farm that is too small to give them full employment. Other things being equal, the farm income is usually very nearly proportional to the size of the farm. Something depends, of course, on the type of farming. If the best type of farming is dairying, for instance, a smaller farm will suffice to make a good income than if the best type is growing corn and wheat for sale.

The ideal size of farm is one that gives full employment to two men throughout the year. One reason for this is that many tasks on the farm require two men. Haying and stacking wheat are examples. Such a farm gives satisfactory employment for the working members of the average farm family, which usually consists of the farmer and one or two growing boys. It is all the better if the boys can attend school during the winter.

A farm of this size ought to produce enough income to permit at least one of its young people to extend his or her studies beyond the common schools.

If the farms of a region are generally much larger than this, the farm population is so scattered that it is difficult to maintain good schools, churches, and roads. In addition to this, a large part of the population must be made up of people who own no land, and who are 
therefore not permanent citizens, decply interested in such institutions as schools, churches, and roads.

Quality of the farm business. The quality of the farm business is measured by such things as yield per acre and product per animal. The importance of these as a means of increasing farm income has already been discussed. In regions where the farm income is largely from crop products, yield per acre becomes perhaps the most important single factor in determining the farm income. In regions where the income is mainly from animal products, the amount of product per animal becomes important.

Character of equipment. A farmer who has too little equipment in the way of implements and machinery loses much time in doing his work. It is an excellent plan to hire the larger and more expensive machinery needed on the farm when this can be done with certainty, but it may be more profitable to own some rather expensive machines than to depend on hiring. On the other hand, many farmers waste money by buying machinery which they do not need or could easily hire. The larger the farm, the more complete equipment it can afford.

Tenure. It is a serious mistake for a man with very little capital to invest that capital in a small patch of land and try to live by farming it. Farm-management studies have shown conclusively that when a man has only capital enough to work a large rented farm he makes on the average about three times as much as he would make with the same type of farming on a farm small enough for him to buy with this same capital. 
It is only when the farmer has accumulated enough capital to be able to make a liberal (one-half or twothirds) payment on a good-sized farm, and still have enough left to furnish the necessary working capital, that he is justified in stepping out of the tenant class. Before that he can make more as a tenant than he can as an owner.

But the advantages of being a land owner rather than a tenant farmer are so great that few men remain tenants after they are able to become owners of farms large enough to make them a good living.

\section{HOW TO ACQUIRE A FARM}

When capital is available. The man who has money enough to pay for a good farm, or even enough to pay half of its value down, provided he has enough left for working capital, may buy when he pleases. He should not buy in any region new to him until he has had a chance to study local land values and is thus able to judge of values for himself. If such a man is not an experienced farmer, it would pay him to get some experience before attempting to farm for himself.

When capital is limited. When the amount of capital available is less than that mentioned above, assuming that the man has had ample farm experience, the best plan to pursue is to become a tenant farmer. By careful saving, a few years should suffice for the accumulation of sufficient capital to justify the purchase of a good farm.

The man with no capital. A study was made of a large number of men who now own good farms in the 
Middle West, but who started out with no capital. They began as hired men on the farm. After four or five years, during which time they saved their wages and established reputations for integrity and industry; they invested their savings and what money they could borrow in working capital and became tenant farmers. Most of them married about this time. After remaining tenants for various periods, as a rule from four to ten years, they made a first payment on a good farm and thus became independent proprietors. Most of these men started out as hired men at about eighteen years of age. At thirty or thirty-five they had acquired ownership - with a mortgage, of course. At forty or fifty they were out of debt. A man of exceptional albility can do better than this. Some of these men owned their homes free of debt by the time they were thirtyfive.

\section{Class Exercise}

List the property of several local farms as in the example below, calculating the percentage investment in each kind of property:

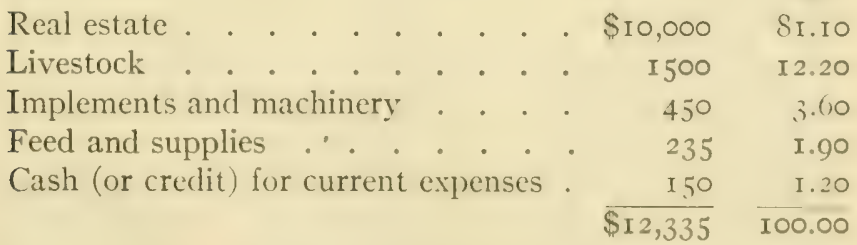




\section{INDEX}

Aberdeen-Angus, 237.

Acetic acid, 107, 212 .

Acid, acetic, I07, 21 2; lactic, I07.

Acid calcium carbonate, 7 .

Acid phosphate, 157, 160.

Acid soils, 107-II6.

Eolian soils, 27-28, map facing 32; size of particles in, 36 .

Air, 1 ; a soil-forming agency, $7-8$; in soils, 58,59 , I09, IIS; relation to decay, 6I; composition of, I30.

Air-slaked lime, II3.

Alabama sjils, 25, II5.

Alcohol, 2I 2 .

Alfalfa, I03, I05, II 2, 272; a legume, I48, I50; seed pod, Fig. 79, I48; seed testing, 298-299.

Alkali, 57, 59, Iro; effect of drainage on, $77-78$.

Alkaline substance Io8-IIO.

Alluvial soils, 26, map facing 32 .

Alsike clover, Ir 2.

American Poultry Association, 252.

American Trotter, $244^{-245}$.

Ammonia, I08, I09, II9; defined, I57.

Ammonium chloride, I57.

Ammonium compounds formed by bacteria, 205.

Ammonium sulfate, I57, I59.

Andalusians, 253.

Angora goats, 250, 318-319.

Angus. See Aberdeen-Angus.

Animals as soil formers, I7.

Animal unit defined, 322 .

Annual plants, r29.

Anther, I63.

Ants' "dairy cows," rog.

Aphis, 192, 196.

Apple canker, 216.

Apple production, 278.

Apple scab, 2 I 6.

Apples, propagation of, I76, I80; affected by pear blight, 216 .

Arab horses, 245.

Arkansas soils, I 5 .

Arsenic, an insecticide, I96.

Atoms, 2, 3.

Ayrshires, 241 .

Baby beef, 304 .

Bacteria, I 23, I3I, I48-I5I, 20I-2I0; in soil, I02, II5, II6, II8, 204-208; nature of, $\mathrm{I} 35,203-204$; nitrace formers, $147,205-208$; nitrate destroyers, I55; distribution of, 203204.
Bacterial diseases, 208 -200 .

Bananas, propagation of, $172-173$.

Bantams, 255.

Bark of trees, 127.

Barred Plymouth Rocks, 253.

Basic slag, 160 .

Bean, a legume, I48.

Beef breeds, 236-239.

Beef calves, raising of, 303-304

Beef cattle, difference between, and dairy cattle, 235; enterprises, 303306.

Bees, I92,

Beeswax, 50.

Beet, food storage in, I25; a biennial, I 29 .

Belgian horses, 245.

Berkshires, 247, 248 .

Bermuda grass, I03, 272; manner of spreading, I75; weedy tendencies of, I 88 .

Berry production, 278 .

Biennials, I 29.

Blackberry vines, 124 ; propagation of, I 74, I76; orange rust of, 214 .

Blight, pear, see Pear blight; potato, see Potato, late blight.

Bluegrass Region soils, I6.

Boll weevil, I97-I99.

Bone meal, 160.

Bone tankage, 160.

Brahma fowls, 255.

Brahmin cattle, 238-239.

Bread, use of yeast in, 212.

Breathing of plants, I4I-I 42 .

Breeders, production of, $220-232$.

Breeds, of livestock, $233-255$; difference between beef and dairy, 235 .

Briers, I24.

Broncos, 246.

Brown Leghorns, 254.

Brown Swiss cattle, 242-243.

Budding, $178-180$.

Buds, I23-I 24.

Bud scales, I24.

Bud sports, I84.

Buildings, part of real estate, 323 .

Bulbs, I74; food storage in, I 25.

Bulls, importance of good, in dairy herds, 3 I 2.

Bur clover, 104.

Burning. See Combustion.

Butter-fat prices, 3 I2.

Butterflies, I95.

Butter production, 307,308 .

Buzzardwing, 69 . 
Cabbage, II 2 ; adapted to muck land, 38 ; a biennial, I 29.

Cacti, 125.

Calcium, I45, I56; nitrate of, I47; sources of, I53; phosphate of, ${ }_{5} \delta$.

Calyx, I62.

Cambium layer, I23, I8o.

Canning, relation to bacteria, 204 .

Capillary action, $45^{-50}$; space in soil, 52.

Capital, personal, 323; working, 323 .

Carbohydrates, required by animal body, 258; sources of, 260 .

Carbon, source of, in plants, I22, I42, 152 .

Carbonic acid gas, II 3,122 ; in breath, 7 ; in air, I3O; in wells, I3I; in silos, I3I; absorbed by leaves, I42-I43; produced in fermentation, $2 \mathrm{I} 2$.

Carrots, food storage in, I25.

Cash for current expenses, part of working capital, 323.

Catch crops, 104.

Caterpillars, 192, I95, I99.

Cattle, 223; breeds of, $235^{-243}$.

Cayuses, 246.

Celery, a muck-land crop, 38 .

Cell, 132-136; number in organisms, I34.

Cell division, I33, I35, I36; in seed formation, 165 .

Cell sap, I33, I34.

Cellulose, composition of, 155 .

Certificate of registration, 231 .

Charcoal, I22.

Cheese factories, 307-308.

Cheese production, 308 .

Chemical action in soil, $7-8,17$.

Chemical elements, number of, 3,4 ; required by crops, 152,153 .

Chemical symbols, 4, 5, I 45, I47.

Chemistry, facts from, $2-7$.

Cherries, propagation, I80.

Chester Whites, 247.

Cheviots, 249.

Chickens, breeds of, 25I-255. See also Poultry.

Chili saltpeter, I47, I59.

Chilled plow, 45 .

Chlorin, injurious to certain crops, I6o.

Chlorophyl, I34, I43, 203.

Cholera, hog, 316.

Chromatin, I33, 134; bodies, 165, I66.

Chrysalis, 200.

Cider, 212.

Clay, defined, 33, 34.

Clay loam, 34.
Clay soil, $34,35,37,39-44,6$ r, Ir 5 .

Cleveland Bays, 244.

Clod masher, 65.

Clods, 39, 40.

Clouds, I3o.

Clover, a legume, I $4 \mathrm{~S}$; seed testing, 208-299.

Clydesdales, 2.4.

Coal oil, 5I-52. See also Kerosene.

Cochineal insect, 192.

Cochins, 255 .

Cocoons, 195 .

Cold frames, 300-30I.

Colluvial soil, 30-3I, map facing 32 .

Columbia River basin, soils of, 36 .

Combustible material required by animal body, 258; proportion needed, 260-26r.

Combustion, $131,256,257$.

Commercial fertilizers. Sce Fertilizers.

Complete fertilizer, I 59.

Compound substances, 4 .

Concentrates, $262-263$.

Condensaries, 307.

Conducting tissue, 136 .

Coöperative marketing, $320-330$.

Copper, 4; sulfate of, 213,215 .

Corn, 100, 104, 106; on muck land, 38 ; roots, Fig. 4r, 73; water content, I4I f flowers of, I65, I68; crossfertilized, 160 ; the leading crop, 270 , 271 ; seed selection and testing, 292296; as hog feed, 315-3I6.

Cornstalks, 223-224, 304.

Corolla, I6 3 .

Corrugated roller, 91 .

Cotswolds, 249 .

Cotton, 92, 99, 100, I0r, I05; limiting factor in acreage of, 274 ; leading fiber crop, 274-275; income per acre and per man, 327 ; why one-horse farming, 327.

Cottonseed meal as fertilizer, I59.

Cotton wilt, 216.

Cowpeas, 104.

Cows, dairy, importance of quality in, 310-312; labor requirements, 31331.4 .

Creameries, $307-308$.

Credit, part of working capital, 323.

Crimson clover, I04, I05.

Crops, areas, 270 ; how to grow, $28_{5}-$ 302.

Crossbreds, I70, 233. Sce also Hybrids.

Cross-fertilization, 168 .

Crown (of plant), 130.

Crystals, ice, II; in soil, IS. 
Cucumber blight, 2 I 6 .

Cultivated crops, relation to weed control, I go.

Cultivators, $70-72$.

Cup fungi, 2 I0.

Currants, propagation, $\mathbf{7} 76$.

Cuttings, 177

Cyanamid, fertilizer, I59.

Cytoplasm, I32-I33, I34.

Dairy breeds, 239-242.

Dairy cattle, different from beef cattle, 235 .

Dairy cows, labor required, 3I3-3I.4. See also Cows.

Dairying, 306-3r5.

Decay of organic matter in the soil, I3O-I3I.

Devon cattle, 243.

Dew, source, I30.

Dirt mulch. Sce Mulch.

Diseases of plants, 2I2-2I9.

Disk harrow, 64 .

Disk plow, 45.

Distribution of soil material, $2 \mathrm{I}-32$.

Doddies. Same as Aberdeen-Angus.

Dogs, a menace to sheep, 3 I 8 .

Dorsets, 249.

Double flowers, 167 .

Double shovel, 69 .

Double standard cattle, 238.

Downy mildews, 2I 2-2I3.

Drag harrow, 63.

Drainage, $77-82$, I I 3 ; effect on air and moisture in soil, $5+$; effect on alkali, $77-78$; system, part of real estate, 323 .

Dried blood, fertilizer, I59.

Driving horses, personal capital, 323.

Drought-resistant crops, $9 \mathrm{I}-92$.

Dry farming, 88-92 ; limits, 83 ; relation to humus, гог.

Dry matter, defined, I4I ; sources in plants, I43.

Dry soil, plowing and tilling, 39-40; capillary action in, $54-55$.

Ducks, 25 I.

Durham cattle. See Shorthorns.

Duroc-Jersey swine, 247, 248.

Durum wheat, 9 I.

Dust mulch. See MIulch.

Dutch Belted cattle, 242.

Dwelling, rental value, 325 .

Elementary substance defined, 3, 4 .

Elements, chemical. See Chemical elements.
Embryo, I7I, I72.

Endosperm, 172.

Energy, bodily, 257.

Engine, principle of, 257 .

English Race Horse, 244, 245.

Epidermis, I64.

Equipment, relation to profits, 333.

Expenses, farm, 324.

Fairy rings, 219.

Fancy points, 252.

Farm, defined, 265; one-man, 224; two-man, 224-225; primary business, 266; investment and income, 323-335; property, 323; small, 326328 ; size, relation to income, 332 ; how to acquire, $334-335$.

Farm business, $265^{-2} 84$.

Farm income, $323,324-326$; details of, 324 ; factors affecting, 329-334.

Fat, animal, 125 .

Favorelles, 255 .

Feed and supplies, part of working capital, 323.

Feeding, principles of, $256-264$.

Feedstuffs, classes of, 262-263.

Fences, part of real estate, 323 .

Ferns, 202.

Fertility, relation to texture, $46-47$; maintenance, 99-I I8.

Fertilization, of ovules, I65-167; of flowers, 168 .

Fertilizer, terms, I57-I $5 \mathrm{~S}$; formulas, I $5^{8}-159$.

Fertilizers, 99, IOI, II6-II 8, I55-I6r ; where mostly used, 26; for muck soils, 38 ; complete, I59; substances used, I59-I6r; kinds and amounts to use, I60-I6I; effect of price on use, 289 .

Feterita, or .

Flies, as disease carriers, 194.

Flint, in limestone, 15,16 ; in soil, $18,26$.

Floats, I58, I60.

Florida phosphate, 160.

Flowers, I23; parts, 162-165; double, I67; modifications of, 167 .

Food, storage in plants, 125-126; uses of, 256; classes required by animal body, 258-259; sources of constituents, 259-260; variety in, necessary, $261-262$; furnished by the farm, 325 .

Food constituents, sources, 259.

Formalin, I97, 215.

French Coach Horse, 245.

Frost, source of, 130 .

Fruit buds, I24. 
Fruits, II7; food storage in, I26; cross-fertilized, I69; quantities needed, 268-269; as scurce of income, $275-276$.

Fuel furnished by the farm, 325 .

Fullbloods, 233.

Fumigation, I97.

Fungi, I23, 210-2I9; nature of, 202; structure, 200-2II; fungous diseases, 212-2I9.

Galloways, 237.

Game chickens, 255.

Geese, 25 I.

Germ of seeds, I7I.

Germ cells, I66.

German Ccach Horse, 245.

Glacial bowlders, 23, 25 .

Glacial soils, 23-24; thickness, I3; location, I3, map facing 32 .

Glaciated stones, I2, I3.

Glaciers, 28; as soil formers, 10-13; as soil movers, 23.

Glass, attraction for water, 49-53.

Goats, 250; place on the farm, 318-319.

Gooseberries, propagation, I74; injured by powdery mildew, 2I3.

Grade animals, 233.

Grafts, $180-182$; influence of stock, $I 8_{3}-I 8_{4}$; hereditary qualities, IS4.

Granitic soil, 22, map facing 32 .

Grape, propagation, I 76 , I77; injured by powdery mildew, 213 .

Grasshoppers, I92-I93.

Grass family, members of, 172 .

Grass flowers, I63.

Grass seed, testing, 298-299.

Gravel, defined, 33.

Great Stone Face, 9.

Green bug. Same as Aphis.

Green coloring matter in plants, I22, I33, I 43 .

Green manures, I03-I05, I I I, I I 2, I I3.

Green slime, 2 I0.

Ground fish, fertilizer, I59.

Growth, rings, 127 ; manner of, 135 .

Guano, I 57 .

Guernseys, 240-2.4I.

Guineas, 25I.

Gummy substances in soil, I8.

Gypsum, I I4, I 56.

Hackneys, 244.

Hair, as fertilizer, I 50 .

Hairy vetch, 104, I48.

Hamburgs, 253.

Hampshire sheep, 249 .
Hampshire swine, 247.

Hardness of water, 56-57.

Harrow, drag, 63; spring tooth, 63; disk, 64 .

Hay, on muck land, 38 ; water content, I4I; value as feed, 226; second in acreage, 270,272 .

Heartwood, I 23.

Heat, how maintained in body, 257 .

Heavy soils, defined, 39.

Heel, scrape, 69; sweep, 69.

Herefords, 237.

Higher fungi, 200-2I I.

Hillside soil, $93,96$.

Hog, wild, 234.

Hog cholera, 3 I 6.

Hogging down crops, 315.

Hogs, 223, 315-316. Sec also Swine.

Holsteins, 239.

Home supplies, production of, 222, 266$267,280,33 \mathrm{I}$

Horns, undesirable, 238.

Horses, breeds, $2+3-246$.

Hot bed, 300 .

Humus, 95, 96-97, 99, 100, 102, 103, Io6, I07, II6, II7, II8. See also Vegetable matter and Organic matter.

Hybrids, r7o; blue Andalusians, 254. See also Crossbreds.

Hydrocyanic acid, 197 .

Hydrogen, source of, in plants, I53.

Ice, a soil former, 9; cxpansion, 9, 20; flexibility, I I.

Implements, tillage, $6 S-72$; part of working capital, 323 .

Income, per cow, relation to profit, 3 II ; per man is. per acre, $320-325$; cffect on, of power used, 327 .

Indiana muck soils, 38 .

Inoculation of legumes, I50.

Insect life, stages, 195-196.

Insects, I02-200; as pollen bearers, I69, I93; domesticated, I92; number of kinds, 102 ; relation to human welfare, 192-104; methods of feeding, so6.

Internal structure of plants, 132-133.

Irish potato. Sec l'otato.

Iron, I 7, I45. 153 .

Irrigation, S2 $_{27}$.

Jerseys, 2.40 .

Johnson grass, I03, I25, I74, 272; eradication, I $86-187$.

Jungle fowl, 254. 
Kafir, 91, 92.

Kainit, r6o.

Kerosene, 200. See also Coal oil.

Labor, seasonal distribution, 28o-28I ; on dairy farms, 3r3-3r4.

Labor income, 325 .

Lactic acid, 107.

Lacustrine soils. See Lake-bottom soils.

Ladybug, I92.

Lady Eglantine, 253, 254 .

Lake-bottom soils, 26, map facing 32.

Land plaster, I $44,{ }_{5} 6$.

Langshans, 255.

Larva, 195.

Lava, 36.

Layering, 176 .

Lead arsenate, I96.

Leaf buds, I2.4.

Leaf mold, iIs.

Leather, as fertilizer, I59.

Leaves, as fertilizers, Ico, Ior; uses, I 22-I 23; arrangement on trees, I23; absorption of $\mathrm{CO}_{2}, \mathrm{I}_{4} 2-\mathrm{I} 43$.

Leghorns, 253.

Legumes, I48-I5I; proteins in, 259.

Leicester sheep, 249.

Light, action in starch formation, I22, I.4.

Light soils, defined, 39 .

Lime, 108, II3-116.

Limestone, II3-II5; action when heated, 5,$7 ;$ muriatic acid test for, II 8 .

Limestone soils, formation of, I3, 2I ; location, I4, 2I, map facing 32 .

Limewater, 6, I ig.

Lincoln sheep, 249 .

Litmus, II3, II8.

Liver fluke, 3 I $7-3$ I 8 .

Livestock, purposes for which kept, 221 ; as scavengers, 223 ; for winter employment, 224-225; relation to size of business, $225^{-226}$; as market for crops, .226-227; as fertility producers, 227-228; production of breeders, 229-232; effect on cropping system, 28I ; enterprises, 303$32 \mathrm{I}$.

Loam soil, $34,35,36,37,6$ I.

Long-wool breeds, 249.

Louisiana soils, 25 .

Louse, as a disease carrier, 194.

Lower organisms, 20I-202.

Lye, IOS, II9.
Maggots, 195 .

Magnesium, 145, 153, I56.

Magnet, 2.

Malaria, 193.

Mangum terrace, $76-77$.

Manure, I02, I52; on muck land, 38 ; fermentation, I55, 208; bacteria in, 203 ; value, 227-229.

Manure spreader, Io3.

Maple sugar, I26.

Marine sediment, 24, II6, II7, map facing 32 .

Marketing, 329-330.

Market milk, 308-310.

Marl, II 4 .

Meadow, use of term, 37 .

Means grass. Sce Johnson grass.

Melon blight, 216 .

Merinos, 249.

Michigan muck lands, 38 .

Milk, sour, bacteria in, 203.

Milk condensaries, 307 .

Millet, I 90.

Milo, 9 I.

Mineral plant food materials, 96,98 , I 45, I 46 .

Mineral substances, required by animal body, 258; sources, 260; animals which need, 262.

Minorcas, 253.

Mississippi River bottom, 26, 28, map facing 32 .

Mississippi soils, 25, II5.

Mistletoe, 202-203.

Mohair, 250.

Moisture, soil, how held, 55. Sce also Soil moisture.

Moldboard plow, 44 .

Molds (fungi), 204.

Molecules, 3, 4, 49 .

Mongrels, 233 .

Mosquitoes, I93, I98, 200.

Mosses, I I 2, 202.

Moths, 195.

Muck, 37-39; effect of manure on, 38 ; color of, 47 ; need of potash, I56.

Muddy water, clarifying, Iro.

Mulch, soil, $45^{-46}, 89$; of sand, 73 .

Mulefoot hog, 248.

Mules, 222.

Multiplier onion, I75.

Muriatic acid, II 8.

Mushrooms, 210.

Mustangs, 246.

Mutton breeds, 249.

Mycelium of fungi, 209. 
Nectar, $x 69$.

New soils, 93-95.

New York muck land, 38 .

Nitrate, destroyers, 206-207; fertilizers, 152; formation of, $205^{-208}$.

Nitrates, I55; symbol of, 147.

Nitrites, 205.

Nitrogen, I46; in air, I30; combined, sources, $\mathrm{I}_{4} 6-\mathrm{I} 47, \mathrm{I}_{52}$; fixing bacteria, I48-I5I; organic, $15 I$; fertilizers, list, I59; substances containing, required by animal body, 258; sources of, as food constituent, 259.

Norman horses, 244.

Nucleus, I33, I34, 203.

Nut grass, 190.

Oat rust, 214 .

Oats, 100, I63, 273; on muck land, 38 .

Ocean bed, soil material on, 25-26.

Ohio muck land, 38.

One-horse farming, $326,327,328$.

One-man farm, 224.

Onions, on muck soil, 38 ; food storage in, I 25 ; propagation, 174.

Orange rust of blackberry, 214.

Orchards, irrigation of, 87 .

Organic matter, 98 ; relation to fertility, I7; sources, I7, I9; relation to water-holding capacity, 56 ; relation to tillage, 6r; defined, 93-94, 99; function in the soil, 95, 96-97; effect of lime on, II6; food for bacteria, I52, 204.

Organic nitrogen, I5I.

Orpingtons, 253.

Osmosis, $137,138,257$.

Ostriches, 25 I.

Ovary, I64, I65.

Ovules, I65, I66.

Oxen, 222.

Oxford sheep, 249

Oxygen, I22; in air, I30; sources, in plants, I52-I53; in blood, 257.

Oyster shells, II.4.

Paraffin, 50.

Parasitic plants, 20I-2I0.

Paris green, I96.

Pasture, I0.4.

Peaches, propagation, ISo.

Peafowls, 25I.

Pea pod, r48.

Pear blight, I93, 209.

Pears, propagation, I80.

Peas, legumes, ${ }_{4} 8$.

Peat, 38 .
Peppermint, 38 .

Percherons, 244.

Perennials, $\mathbf{3} 30$.

Perishables, 279.

Personal capital, 323.

Personal property, 323.

Petals, I62, I69, I70.

Pet stock, 323.

Phosphate, 155, 15S; rock, I57, 158, I60; list of fertilizers, I60.

Phosphoric acid, I5S.

Phosphorus, 145, I 53, I55.

Photosynthesis, 144 .

Pigeons, 251.

Pistil, I64.

Plank drag, 65.

Plant, roots, I9; food, 96 , IIo, II6, I $22, I_{42}-I 43$, I 45 ; organs, I $21-I 2 S$; propagation, $162-185$; diseases, $21_{2}-$ 219.

Planting, depth of, 286.

Plants as soil formers, I7.

Pleasure vehicles, 323 .

Plowing, 39-43, I13; depth of, 6r; purpose of, $6 \mathrm{I}$.

Plows, types, 44-45.

Plums, propagation, I80.

Plymouth Rocks, 253.

Poland Chinas, $247,248$.

Polar ice caps, Ir.

Polled cattle, 237, 238, 239-240.

Pollen, I63-16.4, I66; tube, r66.

Ponies, 245-246.

Poplars, propagation, I77.

Potash, I58; for muck land, 38 ; soils requiring, 156 ; fertilizers, list, 160 .

Potassium, 145, I53; nitrate, I47; sources, 156; chlorid, I60; effect on certain crops, I60; sulfate, I60.

Potatoes, 125 ; relation to acid soil. II2; scab, II2, 216; injured by chlorin, I60; eyes, I73; late blight of, 212-213; seed selection, 296297 ; planting for seed, 297-298.

Poultry, 223, 25I-255; breeds, 25I255 ; standards, 252 ; business, 319 321 ; products, demand for, 320-32I. See also Chickens.

Powdery mildews, 213.

Power, amount used, 327.

Precipitate, 7.

Prices, effect on yield, $2 \mathrm{Sg}$; effect on income, 329.

Prickly pear, I25.

Production of breeders, 229-232.

Productive stock, 323.

Propagation of plants, $16_{2}-175$. 
Property, farm, 323.

Proteins, required by animal body, 258 ; sources of, as a food constituent, 259 ; proportion needed, 260-26I.

Puddling of soil, $4 \mathrm{I}-42,73$.

Pupa, I95.

Purebred, 233; relative value, 233; wellbred vs., 235 .

Quack grass, I25, I74; eradication, I87. Quartz, in earth's crust, 8; in soil, 26.

Quicklime, 5, 6, II3; slaking, 6 .

Quicksilver, 3 .

Quinces, propagation, 176.

Rag-doll methsd of testing seed corn, $294-296$.

Rain, as soil-moving agency, 30-3I; source of, 130.

Rainfall west of Rockies, 89 .

Range sheep, 317-318.

Raspberry, propagation, $174^{-176}$.

Real estate, 323.

Receipts, farm, 324.

Red clover, I05, II 2.

Red Polls, 242.

Registration of farm animals, 230-232.

Renting, 333-335.

Residual soils, $2 \mathrm{I}-22$.

Resting fields, 107.

Rhode Island Reds, 253.

Rings of growth, I 27.

Rocks, of earth's crust, I; action of soil water on, 8 .

Roller, 64.

Root hairs, I2I, I25, I38, I39, I40.

Roots, water absorbed by, 6o; need of air, 6I ; relation to open space in the soil, 63 ; relation to tillage, 72,73 ; corn, 73 ; uses, 121 ; food storage in, 125 .

Rootstocks, I25, I86, I87.

Rose bushes, I24.

Roses, propagation, I77.

Rosette of winter annual, I29.

Rotation, relation to weed control, I9o.

Roughage, 262-263.

Runners, I75.

Rusts of grains, 2I.4-2I5.

Rye, 9I, 104, 105.

Saddle horse, 244, 245 .

Salt, composition, 4 .

Sand, defined, 33 ; a soil type, 34-35.

Sandstone, origin of, 22 .

Sandstone and shale soils, 22, map facing 32 .
Sandy clay, 35 .

Sandy loam, 34 .

Sandy soils, 6 I, I I 5 , I I 8 ; tillage of, 3944; need of potash, 156; truck farming on, 276 .

Sap, storage of food in, 126.

Sapwood, r23.

Scale in boilers, 57,59 .

Scale insects, $196,198$.

Scavengers, 223, 317, 319-321.

Scion, 180,183 .

Scooter, 69.

Scrape, 60 .

Scrub animals, 233.

Seaweeds, 202

Sedimentary soils, $24^{-26}$, map facing 32.

Seed, bed, good, 66-67; pod, I64; formation, I 65-167; formed without fertilization, I67; importance of good, 286; selection and care, 290299 ; corn, selection and care, 292296; potatoes, selection, 296-297; production as a business, 299-300.

Seed testing, corn, 294-296; small seeds, 298-299.

Seeds, food storage in, I26; injury by fertilizers, I60; structure of, I70I72; depth of planting, 286.

Self-fertilization, 168 .

Sepals, 162.

Sets, 126, I74.

Shale, origin of, 22 .

Sheep, 223, 316-3I8; breeds of, 248249 .

Shetland ponies, $245^{-246}$.

Shires, 244.

Shorthorns, 236.

Shropshires, 249.

Silkworms, 192, I95.

Silos, $\mathrm{CO}_{2}$ gas in, $\mathrm{I} 3 \mathrm{I}$.

Silt, 33, 34; loam, 34 .

Sires, importance of, 234.

Size of farm, 332 .

Slag, Thomas (basic), I6o.

Slaked lime, 6, 7, II3, II .

Smothering crops, I90.

Smuts, $214^{-215}$.

Sod, pulverizing, $64-65$; crops, I03.

Soda, I I 7 .

Sodium, symbol, 5 ; nitrate, I $47,159$.

Softness of water, $56-57$.

Soil, I-I20; thickness of, I ; agencies in forming, 7-18; nature of, 8; erosion, 8, 27-28; water, 8,98 ; complexity of, I7-I 8 ; gummy substances in, I8; cubic inch, magnified, 
I8-I9; particles, I9; sizes, $33,35^{-}$ 37. 47-48; types, $34-39$, I17; puddling, 4I-42, 73; color, 47; air, 58, 59, II8, I30; improvement, 93-I 20 ; bacteria, I1 $8,203,204-208$; inoculation, I50.

Soil material, on ocean bed, I, 25-26; origin of, $7-18$; distribution of, $2 \mathrm{I}^{-}$ 32.

Soil moisture, 39-44, 49-50.

Soil particles, 19 ; size, $33,35-37,47$, 48.

Soil texture, $33-48$; relation to plow types, $44-45$; relation to mulch, $45^{-46}$; relation to fertilization, 4647 ; method of testing, 47; relation to capillary action, $55^{-56}$.

Sorghum, 106, I90; drought resistance of, 9I.

Sorrel, II 2 .

Soudan grass, or

Sour milk, 107, 108, II9, 203.

Sourness of soil, I07, II 6 .

South Carolina rock phosphate, 160.

Southdowns, 249.

Soy beans, 104.

Spanish fowls, 253.

Specialized is. general farming, 232283.

Sphere, volume of, 20 .

Spiketooth harrow. Same as Drag harrow.

Spines, 125 .

Spores, 20I-202; of toadstool, 2II.

Sports, bud, I84.

Spot fungi, $2 \times 5$.

Springtooth harrow, 63, 64 .

Spring wheat, $272-273$.

Sprouts, I2I, I 73 .

Squashbug, I96, 197.

Stamens, I63.

Staple crops, 229.

Starch, storage as food, I25; formation of, I33. I44; food for bacteria, 204.

Steers, fattening of, 304-306.

Stems of plants, uses, I $22-123$.

Stigma, r64.

Stomach worms, 3I7-3I8.

Stone fences, 24,25 .

Stones, weathering of, 8; rolling, as soil formers, xo.

Straw, 304; fertilizing value, I0r; food for bacteria, 204; utilization of, 223-224.

Strawberries, propagation, 175; income from, 326.
Structure of the earth. I.

Style, I64.

Subsoiling, 62-63.

Subsoils, humus content of, 62 .

Subsurface packer, 90.

Suckers, I73.

Sugar, 107; 108; storage as food, I25.

Sugar beets, irrigation of, 86 ; injured by certain fertilizers, 160 .

Sulfur, 4, II4, I.45; sources, I53; use as fertilizer, 156 .

Sulfureted hydrogen, 197.

Sulfuric acid, 158.

Summer-fallow, I00.

Sunflowers, flowers of, I6.4.

Surface cultivator, $7 \mathrm{I}$.

Swamp land, defined, 37 .

Sweep, 68, 69.

Sweet clover, I 50.

Sweet potato, food storage in, I25; propagation, $173-174$, I 77 .

Swine, breeds of, $247-248$.

Symbols, chemical, $4-7$, I 45, I 47 .

Tallow, 50 .

Tankage, fertilizer, r59; bone, r6o.

Tenant farming, 333-335.

Tennessee phosphate, I6o.

Terracing, $74-77$.

Texas, soils of, 25 , II 5 .

Thomas slag, 160 .

Thorns, I24.

Thoroughbreds, 244,245 .

Tick fever, 193-194.

Tile, how made, 78-79.

Tillage, $60-73$, I 3 ; relation to moisture, 39,44 ; before plowing. $65-66$; why certain crops are tilled, 68.

Tillage implements, $68-72$.

Timothy, and clover, 103, 272; food storage in, 125.

Toadstools, 2II, 2 I0.

Tobacco, I60, I73; worms, 105.

Tomato blight, 216.

Tractors, 200.

Transported soils, 22-3I.

Trotter, 2.4.

Truck crops, irrigation, 83 .

Truck farming, $38,39,275-276$.

Tubercles, $149,150$.

Tuberculosis, 209 .

Tubers, I25.

Turkeys, $25 \mathrm{I}$.

Turnips, I25, I 29.

Two-horse farm, 326, 328 .

Two-man farm, $224^{-225}$.

Types of soil, 34-39. 
Typhoid fever, I94.

Typhus fever, I94.

Valley soil, 93, 96 .

Variety in food for animals, $26 \mathrm{I}-262$.

Vegetable matter, in muck soil, $37-38$; relation to soil color, 47; in dry farming, ror. See also Humus and Organic matter.

Vegetables, II 7; why hard to sell, 268 ; quantities needed, 269; as source of income, $275-276$.

Vetches, 104, 148 .

Vinegar, 107.

Vitamins, necessary in food for animals, 259 ; sources of, 250 .

Water, $\mathrm{I}$; freezing, expansion of, 9 ; capillary action in soil, $53-58$; hardness of, 56-57; amount used by plants, 60, 122; how lost, 88-89; clarifying of muddy, I15, I19; uses in plants, 140 ; amount in plants, $\mathrm{I}+\mathrm{I}$.

Water pipes, bursting of, 9 .

Water supply, part of real estate, 328 .

Water vapor in air, I3O.

Waxy material in soil, I9.

Weeds, 6I, 66-68, I86-I9I; why injurious, 89 ; as green manure, 106107.
Wet soil, tillage of, $4 \mathbf{1}-44$; capillary action in, $54^{-55}$.

Wheat, 9I; a member of the grass family, 163; stigmas of, 165 ; rust, 214 ; third crop in acreage, 272 ; limits, winter and spring, 272-273.

White Leghorns, 254.

White Wyandottes, 253.

Wild garlic, I74, I75, I88-189.

Wild mustard, I9o.

Willows, propagation, I77.

Wind, a soil transporter, 36 .

Windbreaks, 38-39.

Winter annuals, I29, I89-190.

Winter wheat, $272-273$.

Wood, components of, 256 .

Wood ashes, 98, I60, 256.

Wool breeds, 249 .

Wool waste as fertilizer, I59.

Working capital, 323 .

Work stock, 22I-222, 223.

Wrigglers, 198.

Wyandottes, 253.

Yeasts, I34, I35, 204, 2 I I-2 I 2.

Yellow fever, 193 .

Yields, how obtained, 285-288; effect on profits, 288; effect of prices on, 289 .

Yorkshires, 247. 





\section{LIBRARY OF CONGRESS}

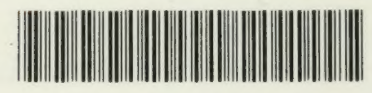

00025864268

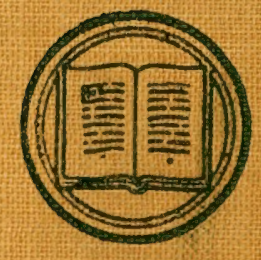

